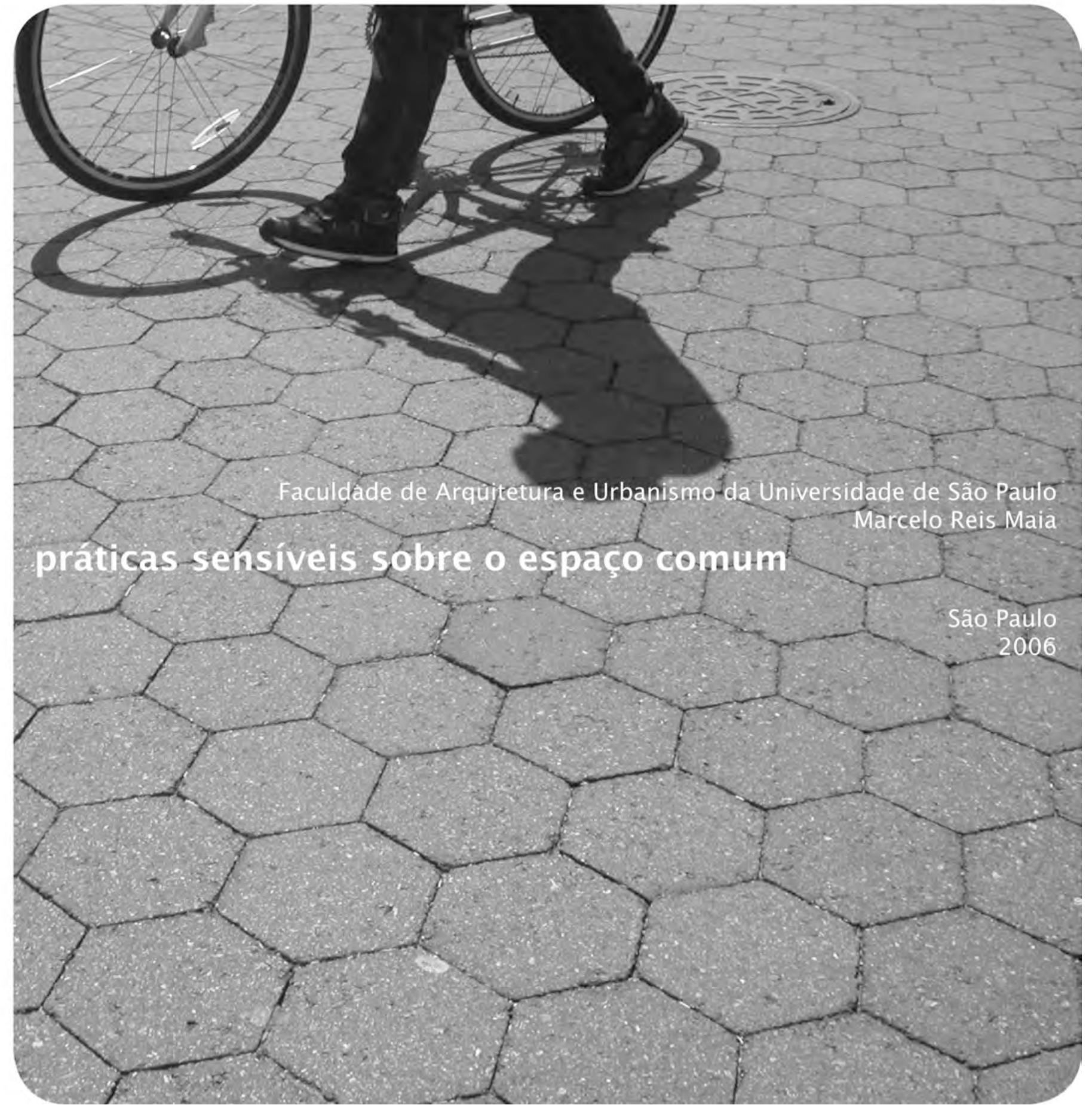


Marcelo Reis Maia

\section{Práticas sensíveis sobre o espaço comum}

Dissertação apresentada ao Curso de Pós-Graduação da Faculdade de Arquitetura e Urbanismo da Universidade de São Paulo, como requisito parcial à obtenção do título de Mestre em Arquitetura e Urbanismo.

área de concentração: Design e Arquitetura orientador: Carlos Roberto Zibel Costa 
AUTORIZO A REPRODUÇÃO E DIVULGAÇÃO TOTAL OU PARCIAL DESTE TRABALHO, POR QUALQUER MEIO CONVENCIONAL OU ELETRÔNICO, PARA FINS DE ESTUDO E PESQUISA, DESDE QUE CITADA A FONTE.

ASSINATURA:

E-MAIL:

Maia, Marcelo Reis

M217p Práticas sensíveis sobre o espaço comum / Marcelo Reis

Maia. --São Paulo, 2006.

176 p. : il.

Dissertação (Mestrado - Área de Concentração: Design e

Arquitetura) - FAUUSP.

Orientador: Carlos Roberto Zibel Costa

1.Produção do espaço urbano 2.Paisagem urbana

3.Arquitetura 4.Design I.Título

CDU 711:330.191.3 
Dedico este trabalho ao futuro Arquiteto e Urbanista. Em especial, ao CAU - Curso de Arquitetura e Urbanismo do UnilesteMG, fonte inesgotável de discussões, experiências e inspirações; à todos os amigos que fazem e fizeram parte deste espaço. 
Agradeço aos amigos pelo suporte, à família pelo apoio e a Deus pela condição. Em especial, ao Zibel pelo acolhimento na FAU, aos meus pais, Adriel e Mariluse pelo apoio constante e carinhoso abrigo em São Paulo durante o curso, à minha esposa Sílvia pela compreensão e aos amigos Alemar Rena, Alexandre Campos (Tande), Frederico Canuto e Louise Ganz pelas conversas essenciais. 
O modernismo só podia falar do eterno ao congelar o tempo e todas as suas qualidades transitórias. (HARVEY, 1999, pg. 30)

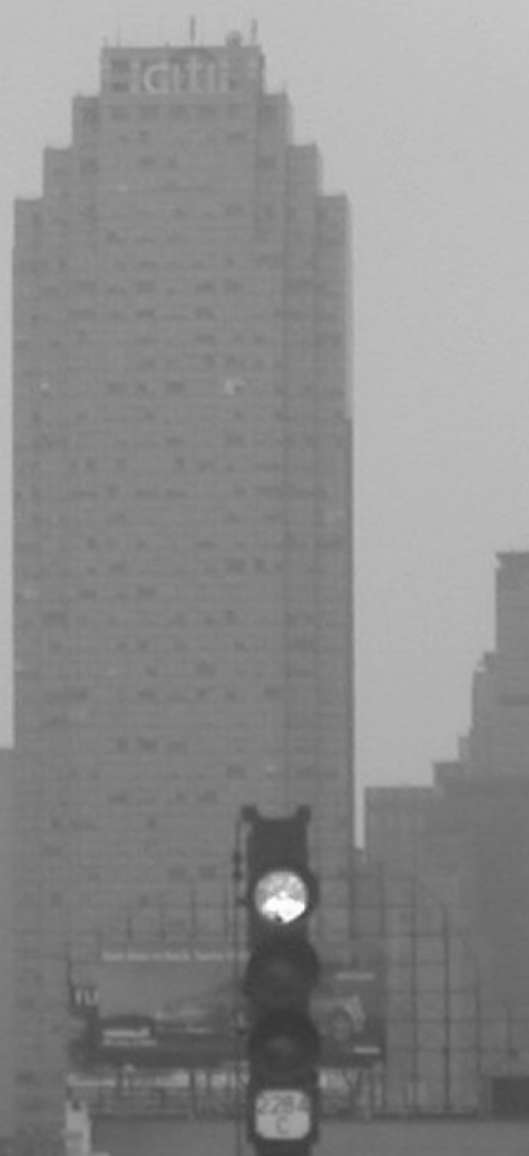

\section{1}




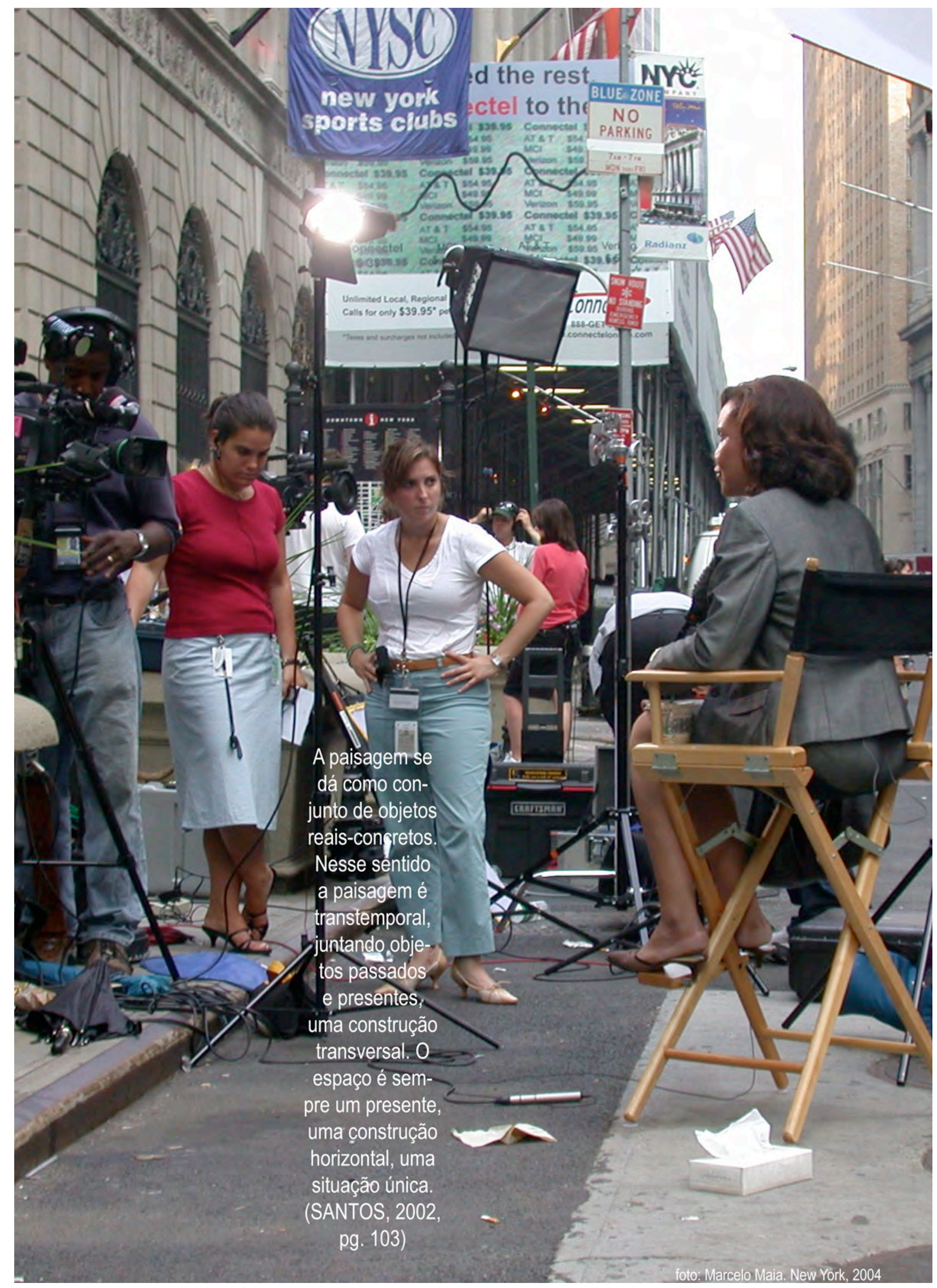




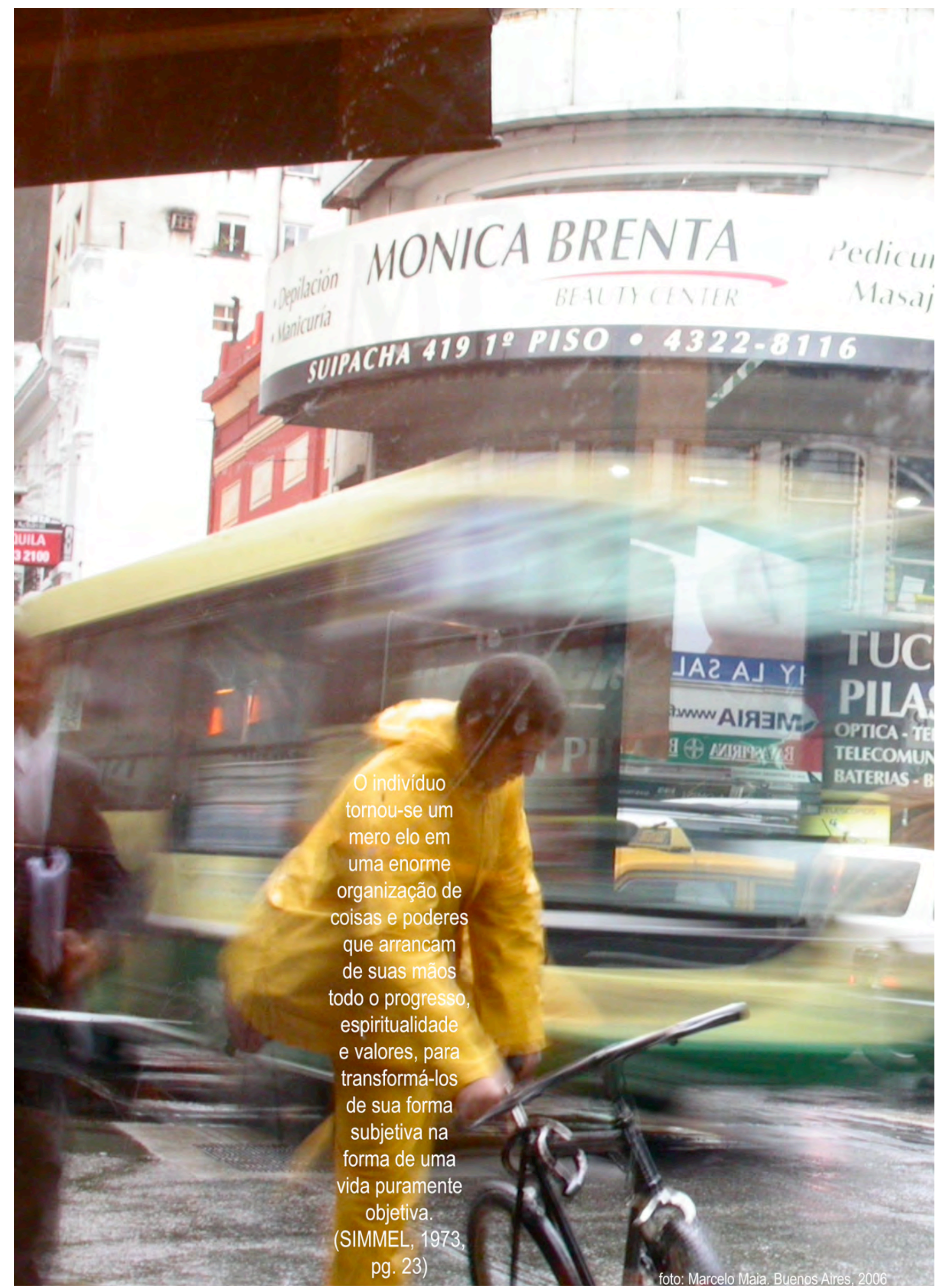



Caminhando por referências bibliográficas, esta dissertação buscou construir um tema comum para se pensar e praticar a arquitetura e o design na sociedade contemporânea. 0 tema proposto aqui é o espaço comum. Aqui, comum é entendido como banal, genérico, recorrente, freqüente, compartilhado, repartido, coletivo, entre outras interpretações; o espaço comum é um cenário critico e instrumental. O espaço comum é uma releitura crítica do espaço, da paisagem e do tempo na sociedade urbana contemporânea. Paralelamente a este cenário critico, trazemos as práticas sensíveis sobre o espaço comum. A prática é o eixo deste trabalho e a sensibilidade seu impulso. Este trabalho, apesar das referencias teóricas e conceituais apresentadas no primeiro capítulo, é um trabalho prático. Seu conteúdo está centrado nos produtos que o acompanham. Logo, o DVD-Rom inserido na contracapa deste trabalho não deve ser apreciado como um conteúdo adicional. Este é parte essencial deste trabalho assim como o texto. Buscamos ainda abrir questões para se pensar o papel do arquiteto e do designer enquanto propositor de uma cultura urbana. Este trabalho, que parte da hipótese em que a sociedade urbana Lefebvriana é um rumo comum, pergunta: como pode 0 arquiteto fazer parte efetivamente deste movimento social sem ser um espectador arrastado entre correntes e tendências da cultura? Também, enquanto uma análise crítica da linguagem usada por arquitetos e designers, as práticas sensíveis sobre 0 espaço comum, ilustram e indicam o potencial existente na linguagem eletrônica para se perceber, experimentar, e intervir em espaços urbanos. Enfim, fotografias digitais, panoramas, animações, vídeos, músicas e registros sonoros práticos impulsionados pela sensibilidade urbana resultam em produtos que serão apresentados ao longo deste trabalho paralelamente ao texto. 
abstract

Through bibliographic references, this thesis envisages a common theme to think and practice architecture and design in the contemporary society. The subject in study is the common space. In this context, common space is defined as trivial, generic, recurrent, frequent, shared by groups, among other interpretations. The common space is a stage for critique and work. The common space can be redefined with a critical view of space, landscape and time in the contemporary society. In parallel to this critical view, we bring sensitive practices to the common space. Hands-on is the axis of this work and sensitivity its drive. This thesis is a practical work in spite of the theoretical references presented and discussed in the first chapter. Its core is in the contents of the DVD-Rom attached, which is an integral part of the work in the same way as the written text is. In the research we propose the role of the architect and designer as a direct influence in urban culture. This work hypothesis is that the Lefebvre's urban society is a common goal, and so, how can an architect be part of this movement without being a simple spectator being pushed by cultural currents and tendencies? Still, the language used by architects and designers, with sensitive interferences in the urban space, indicate the potential of the use of digital language to perceive, experiment and intervene in urban spaces. Finally, digital photographs, images, animations, videos, music and sounds can be products as presented in this thesis in addition to the written text. 


\section{termos e produtos}

Esta dissertação introduz alguns termos e alguns produtos ${ }^{1}$ que são acompanhados do símbolo MM Este símbolo identifica termos e/ou produtos operativos desenvolvidos ao longo do trabalho. 


\section{lista de figuras}

.fig.1. organização e desenvolvimento do trabalho ao longo dos capítulos. pg. 11.

.fig.2. relação entre o texto e os demais conteúdos da dissertação. pg. 12.

.fig.3. esquema teórico de Henri Lefebvre (LEFEBVRE, 2004, pg. 27) pg. 21.

.fig.4. diagrama síntese das idéias de Santos e Lefebvre. pg. 51.

.fig.5. panorama temporário de uma avenida, 5a Avenida, NY, julho 2004. pg. 106.

.fig.6. seqüência de fotografias tiradas na 5a Avenida, NY em julho 2004. pg 106.

.fig.7. detalhe das fotografias. pg. 108.

fig.8. página inicial do iTunes Store de distribuição, procura e divulgação de podcasts. pg. 128.

.fig.9. página inicial do Podscope no dia 17/01/2006. pg. 131.

.fig.10. busca por "vídeo art" no podscope e a lista das primeiras ocorrências. pg. 131.

.fig.11. link para o podcast referente ao trabalho de Bill Viola, publicado por soundcheck, programa da WNYC.org. pg. 132.

.fig.12. sinopse do programa da WNYC.org sobre Bill Viola. pg. 132.

.fig.13. outros programas da WNYC.org. Por curiosidade, segui o link do "The Brian Lehrer Show". O link me levou para o iTunes Store conforme mostra a figura 12. pg. 133.

.fig.14. WNYC.org Brian Lehrer Show na interface do iTunes para ler e gerenciar os RSS feeders do programa. Observe a lista com os programas já publicados, a direita seguem as informações; artista, data da publicação, e sinopse. Esta interface mostra apenas as primeiras palavras do texto, 0 texto completo pode ser visto clicando ícone circular cinza. pg. 133.

.fig.15. lista de Vídeo Podcasts publicados pelo iTunes. pg. 134.

.fig.16. Four Eyed Monster Video Podcast segundo publicação no iTunes Store em 17/01/2006. pg. 135.

.fig.17. sinópse do episódio selecionado. pg. 136.

.fig.18. Four Eyed Monsters, Video Podcast sendo exibido numa janela e a sinópse do programa. Interface do iTunes em 17/01/2006. pg. 136.

fig.19. fluxo de idéias. pg. 141.

.fig.20. rebatimentos. pg. 141.

.fig.21. internet landscape project publicado em http://rhizome.org. pg. 148. 


\section{sumário}

introdução

p.9

capítulo 1

1. 0 espaço comum p.13

$\begin{array}{ll}\text { 1.1. sobre o espaço comum } & \text { p.16 }\end{array}$

1.1.1. o urbano e o modo de vida comum [ encontros e desencontros ] p.20

1.1.2. tempo de diversão [ playtime ] p.30

1.1.3. espaço, paisagem e eventos [ dogville ] p.41

capítulo 2

2. a experiência comum p.56

2.1. hipóteses de percepção, análise e critica do espaço - a paisagem

material e a imaterial $\quad$ p.58

2.1.1. análise dos ritmos do cotidiano (Lefebvre - Rhythmanalysis) p.63

2.1.2. paisagem de eventos (Paul Virilio e Tschumi) p.67

2.1.3. paisagem sonora p.72

2.1.4. body violence (Tschumi - Architecture and Disjunction) p.75

2.2. posições do observador/pesquisador; 0 corpo no

$\begin{array}{ll}\text { urbano - o corpo na paisagem } & \text { p.78 }\end{array}$

2.2.1. procedimentos analíticos do corpo na paisagem;

da patologia à imersão $\quad$ p.79

2.2.2. a imersão corporal paisagística e seus procedimentos operativos p.81

2.3. práticas: visualização e percepção do espaço comum p.83

2.3.1. considerações gerais $\quad$ p.85

2.3.1.1. a fotografia $\quad$ p.88

2.3.1.2. o panorama p.91

2.3.1.3. o Podcast e o iPod p.94

2.3.2. os experimentos p.99

2.3.2.1. o panorama temporário ${ }^{\mathrm{MM}} \mid$ panorama.temporario.org p.101

2.3.2.2. paisagens temporárias $\mathrm{MM} \mid$ temporarylandscape.com p.110

2.3.2.3. 15 minutos $^{\mathrm{MM}} \quad$ p.113

2.3.2.4. diárias urbanas $\mathrm{MM}^{\mathrm{MM}} \quad \mathrm{p} .118$

2.3.2.5. podscape ${ }^{\mathrm{MM}} \quad$ p.126

2.3.2.6. MMSoundscapes ${ }^{M M} \quad$ p.138

$\begin{array}{lr}\text { conclusão } & \text { p.140 }\end{array}$

$\begin{array}{lr}\text { referências bibliográficas } & \text { p.149 }\end{array}$

$\begin{array}{lr}\text { anexos } & \text { p.152 }\end{array}$ 
introdução 
O espaço urbano é dado por uma relação dinâmica entre paisagens e eventos no cotidiano de uma sociedade. O urbano aqui deixa de ser apenas um termo e passa ser entendido como espaço. Enquanto espaço, o urbano torna-se um modo de vida. 0 modo de vida urbano, baseado na dinâmica paisagem-eventos, é um espaço coletivo compartilhado por estranhos e desconhecidos. São paisagens coletivas e eventos coletivos. Um coletivo de indivíduos vivendo e compartilhando paisagens e eventos num espaço comum. 0 capítulo 1, procura construir o espaço comum revisando textos e conceitos de outros autores sobre os seguintes temas:

- 0 urbano

- $\quad$ o modo de vida

- $\quad$ o tempo (moderno, pós-moderno e o processo de modernização)

- 0 espaço

- os eventos

- a paisagem

Este capítulo aborda a relação deste trabalho com o urbano, a paisagem e o tempo dentro dos escopos conceituais dos autores referenciados.

Este trabalho se destaca pelos seus procedimentos práticos. Não foi nosso objetivo adotar uma postura distanciada fazendo uma pesquisa baseada em panoramas gerais, bibliografias, pesquisas, dados e teorias. Procuramos, a partir da inserção do pesquisador, experimentar e perceber o objeto de análise - 0 espaço comum. A essência da análise está na prática e no potencial criativo para se propor e estabelecer experiências práticas e sensíveis sobre o espaço comum (o urbano).

No capítulo 2, Antes de expor experiências práticas sobre o espaço comum, (subitem 2.3) vamos apresentar e comentar alguns métodos e procedimentos de análise e pesquisa do espaço urbano adotado por outros autores (subitem 2.1) que são semelhantes ou que tenha alguma relação com as práticas desenvolvidas ao longo deste trabalho. Também, serão apresentados métodos, procedimentos e posturas adotados e/ou desenvolvidas ao fazer os experimentos apresentados (subitem 2.2).

Além dos procedimentos metodológicos e das posturas adotadas, serão apresentados e discutidos os instrumentos usados nas práticas. A princípio são eles: a fotografia, o panorama, o vídeo, o cinema e o podcast. Também buscou-se apresentar suas possibilidades técnicas, seus conceitos essenciais e potenciais aplicado aos processos espaciais experimentados.

Os experimentos serão introduzidos e comentados individualmente construindo um relatório não apenas descritivo do que foi feito, das técnicas, dos métodos e dos procedimentos utilizados, mas também uma análise critica da própria experiência relacionando-o às questões referentes à experiência comum - 0 espaço comum. 


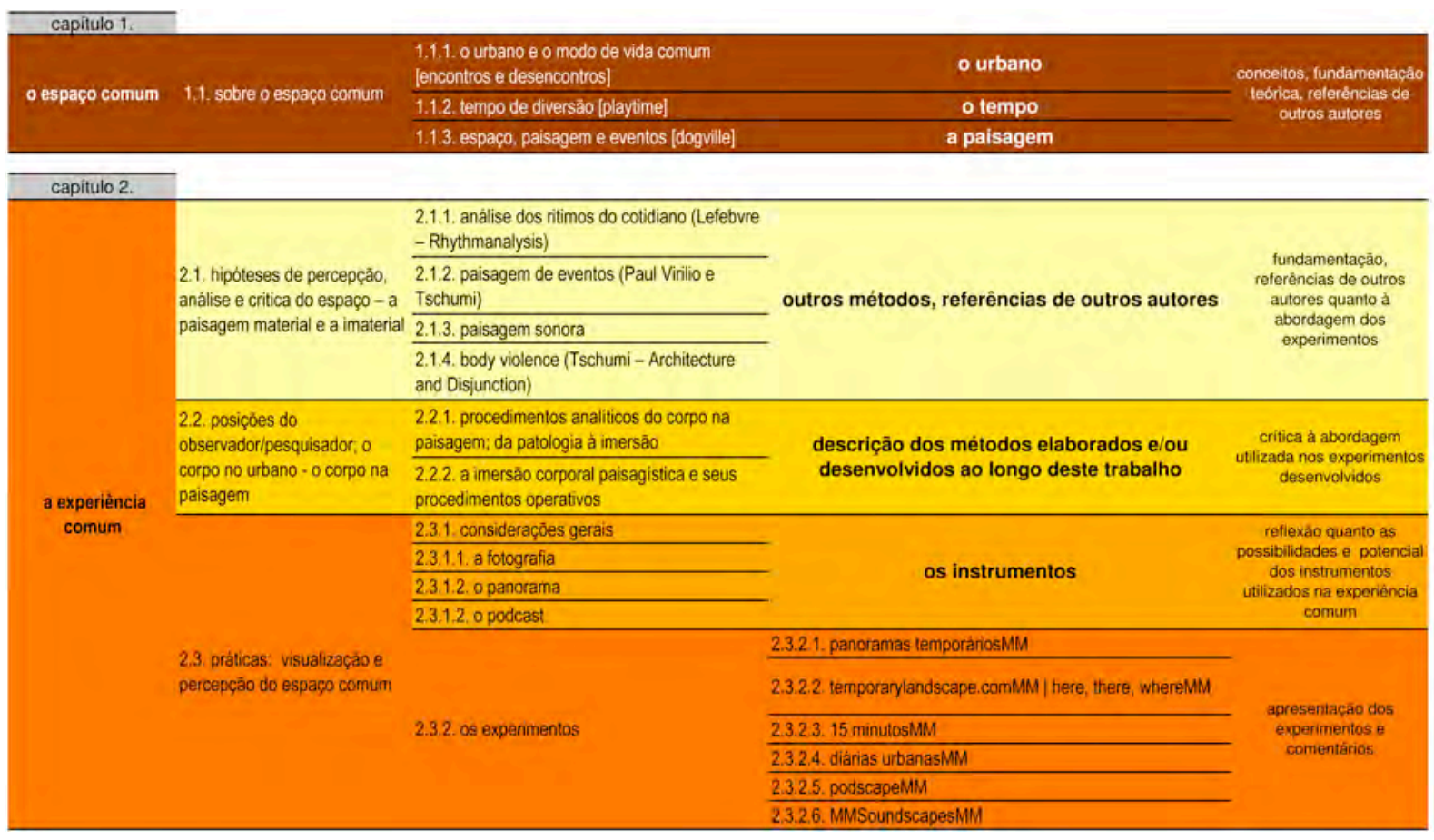

fig.1. organização e desenvolvimento do trabalho ao longo dos capítulos. 


\section{conteúdos}

O trabalho (dissertação) também é composto por vídeos, ensaios fotográficos, registros sonoros e multimídias. O texto está incluso no corpo da dissertação juntamente com algumas ilustrações de referência imediata. Os demais conteúdos deste trabalho se encontram no DVD-Rom.

Para visualizar o conteúdo do DVD-Rom será necessário um computador com um leitor de DVD. As instruções de funcionamento e especificações técnicas se encontram no encarte que acompanha o mesmo na contracapa deste volume.

Ao longo do texto serão indicadas as referências com os demais conteúdos, entretanto, para uma rápida visualização, reapresento o sumário incluindo os conteúdos paralelos ao texto que se encontram no DVDRom (ver figura 1).

\begin{tabular}{|c|c|c|c|c|}
\hline \multicolumn{4}{|c|}{ textos } & $\begin{array}{l}\text { vídeos, ensaios fotográficos, cenas } \\
\text { de filmes, registros sonoros e } \\
\text { multimidias }\end{array}$ \\
\hline capítulo 1. & & & & \\
\hline \multirow{3}{*}{ o espaço comum } & \multirow{3}{*}{ 1.1. sobre o espaço comum } & $\begin{array}{l}\text { 1.1.1. o urbano e o modo de vida comum [ } \\
\text { encontros e desencontros ] }\end{array}$ & & $\begin{array}{l}\text { cenas do filme "Lost in Translation" } \\
\text { de Sofia Copola e cenas do filme } \\
\text { "Fight Club" de David Fincher }\end{array}$ \\
\hline & & 1.1.2. tempo de diversão [ playtime ] & & $\begin{array}{l}\text { cenas do filme "Playtime" de Jaques } \\
\text { Tati }\end{array}$ \\
\hline & & 1.1.3. espaço, paisagem e eventos [ dogville ] & & \\
\hline \multicolumn{5}{|l|}{ capitulo 2.} \\
\hline \multirow{16}{*}{ a experiência comum } & \multirow{4}{*}{$\begin{array}{l}\text { 2.1. hipóteses de percepção, } \\
\text { análise e critica do espaço-a } \\
\text { paisagem material e a imaterial }\end{array}$} & $\begin{array}{l}\text { 2.1.1. análise dos ritimos do cotidiano (Lefebvre } \\
\text { - Rhythmanalysis) }\end{array}$ & & \\
\hline & & $\begin{array}{l}\text { 2.1.2. paisagem de eventos (Paul Virlio e } \\
\text { Tschumi) }\end{array}$ & & \\
\hline & & 2.1.3. paisagem sonora & & \\
\hline & & $\begin{array}{l}\text { 2.1.4. body violence (Tschumi - Architecture } \\
\text { and Disjunction) }\end{array}$ & & \\
\hline & \multirow{2}{*}{$\begin{array}{l}\text { 2.2. posiçōes do } \\
\text { observador/pesquisador; } 0 \\
\text { corpo no urbano - o corpo na } \\
\text { paisagem }\end{array}$} & $\begin{array}{l}\text { 2.2.1. procedimentos analiticos do corpo na } \\
\text { paisagem; da patologia à imersão }\end{array}$ & & \\
\hline & & $\begin{array}{l}\text { 2.2.2. a imersão corporal paisagistica e seus } \\
\text { procedimentos operativos }\end{array}$ & & \\
\hline & \multirow{10}{*}{$\begin{array}{l}\text { 2.3. práticas: visualização e } \\
\text { percepção do espaço comum }\end{array}$} & 2.3.1. consideraçōes gerais & & \\
\hline & & 2.3.1.1. a fotografia & & \\
\hline & & 2.3.1.2. o panorama & & \\
\hline & & 2.3.1.2. o podcast & & \\
\hline & & \multirow{6}{*}{ 2.3.2. os experimentos } & 2.3.2.1. panoramas temporários $M M$ & $\begin{array}{l}\text { ver o ensaio fotográfico e o } \\
\text { multimídia "panoramas temporários" }\end{array}$ \\
\hline & & & $\begin{array}{l}\text { 2.3.2.2. temporarylandscape.comMM | here, there, } \\
\text { whereMM }\end{array}$ & $\begin{array}{l}\text { ver o multimídia "here, there, } \\
\text { where?" }\end{array}$ \\
\hline & & & 2.3.2.3. 15 minutosMM & ver o ensaio fotográfico 15 minutos \\
\hline & & & 2.3.2.4. diárias urbanasMM & ver o vídeo "diárias urbanas" \\
\hline & & & 2.3.2.5. podscapeMM & ver o vídeo "podscape" \\
\hline & & & 2.3.2.6. MMSoundscapesMM & ver o multimídia "MMSoundscapes" \\
\hline \multicolumn{5}{|l|}{ conclusão. } \\
\hline & & & & $\begin{array}{l}\text { ver a seleção de vídeos "CAU" e } \\
\text { "Bienal 2006: Agua" }\end{array}$ \\
\hline
\end{tabular}

fig.2. relação entre o texto e os demais conteúdos da dissertação. 
capítulo 1.

o espaço comum ${ }^{\mathrm{MM}}$ 
Espaço comum ${ }^{\mathrm{MM}}$ : termo desenvolvido e adotado neste trabalho para conceituar e discutir questões do espaço urbano tangentes à prática do arquiteto, urbanista e designer.

O trabalho está dividido em dois capítulos. O primeiro, constrói as questões que serão abordadas no desenvolvimento do trabalho a partir de conceitos e teorias apresentados por alguns autores. 0 segundo capítulo será o momento para expor experiências e práticas relacionadas ao que foi construído no primeiro capítulo.

Cada um dos subitens do capítulo 1 discute e conceitua cada um dos principais termos conceituais deste trabalho - o urbano, a paisagem e o tempo - relacionando-os da seguinte forma:

o urbano > subitem 1.1.1. o urbano e o modo de vida comum [ encontros e desencontros ]

o tempo > subitem 1.1.2. tempo de diversão [ playtime ]

a paisagem > subitem 1.1.3. espaço, paisagem e eventos [ dogville ]

Cada parte abordará um recorte temático que ao final, em conjunto, delineará o termo espaço comum. Cada um dos temas é ilustrado por um longa metragem, sendo assim, paralelamente ao texto, o espaço comum também será conceituado e apresentado em três filmes.

\section{parte 1. o urbano e o modo de vida comum}

Neste momento 0 urbano enquanto prática social é destacado do urbanismo. 0 urbano não é uma disciplina e muito menos uma teoria. O urbano no espaço comum é Urbanismo como Modo de Vida (Wirth, 1973), um conceito fundamental. Outras abordagens referentes ao urbano colocadas por Henri Lefebvre e pela Internacional Situacionista também serão consideradas. Aqui o filme Encontros e Desencontros (2004) de Sofia Copola ilustra e estabelece um diálogo com o texto juntamente com o filme Clube da Luta (1999) de David Fincher.

parte 2. o tempo

Aqui o processo de modernização e suas implicações culturais serão abordados a partir dos textos de David Harvey, Gilles Lipovetsky e Guy Debord. Tempo, uma das dimensões do espaço, aqui especificamente, é uma dimensão sócio-cultural do espaço comum. Paralelamente o filme Playtime (1967) de Jaques Tati ilustrará o tema apresentado. 
parte 3. espaço, paisagem e eventos

Nesta parte serão abordados os conceitos instrumentais que serão adotados neste trabalho referentes ao espaço - principalmente, espaço urbano. Milton Santos e Henri Lèfebvre seriam os autores de apoio e o filme Dogville (2004) de Lars Von Trier o diálogo.

Os filmes indicados tiveram cenas selecionadas, recortas, editadas e incluídas no DVD-Rom anexo. Pretende-se com as cenas ilustrar os recortes temáticos de cada parte e ampliar a percepção conceitual do espaço comum. O filme Dogville será apresentado apenas por fotogramas impressos de algumas cenas incluídos no anexo do trabalho. 
1.1

sobre o espaço comum

1. o espaço comum

1.1. sobre o espaço comum

1.1.1. o urbano e o modo de vida comum [ encontros e desencontros ]

1.1.2. tempo de diversão [playtime ]

1.1.3. espaço, paisagem e eventos [ dogville ] 
O espaço comum é o urbano. O urbano como modo de vida (Louis Wirth), ou, um espaço vivido (Henri Lefebvre). Este espaço comum não é o objeto de uma idealização ou uma concepção planejada. É um espaço dinâmico que, a partir de produtos culturais - incluso nestes o projeto arquitetônico e o planejamento urbano -, está em constante transformação sendo criado e re-criado constantemente. Aos produtores culturais (arquitetos, planejadores, designers, artistas, etc.) cabe a intervenção neste espaço. Intervir ou intrometer-se implica uma participação do produtor cultural um pouco mais ativa. Implica não apenas conhecer os espaços a serem objeto de intervenção, mas também participar destes espaços. 0 espaço urbano é comum pois ele se refere a todos, não é possível ficar de fora. A posição privilegiada e afastada dos planejadores e de seus instrumentos de representação e concepção que os afastam do espaço de intervenção são tecnicamente infalíveis e humanamente questionáveis (Sérgio Ferro)². Infalíveis se o mundo moderno idealizado que incluía um homem fictício neste espaço fosse um campo real. Sabemos que os procedimentos de planejamentos se revelam a cada dia inoperantes diante das dinâmicas espaciais urbanas. São dinâmicas cada vez mais instáveis e fluidas (Zigmunt Bauman). Qualquer política, planejamento, ação e/ou intervenção no espaço gera uma reação no sistema espacial (Milton Santos) afetando a todos, logo comum. A ideologia que promove 0 espaço segregado, exclusivo, que sustentam posições sociais de alguns indivíduos no espaço urbano são cada vez mais recorrentes. O dia 11 de setembro tornou-se um marco mundial, um monumento eventual (Paul Virilio), um sintoma de que por mais que o planejamento, o design, etc. contemplem intervenções que idealizem um espaço urbano paralelo ao espaço urbano comum, o comum se mostra cada vez mais inevitável. Este marco, revela também que os instrumentos de idealização e intervenção modernos, que são baseados e dependentes dos espaços físicos (geométricos) e pouco ou quase nada dinâmicos entram em colapso à medida que as dinâmicas eventuais (temporárias) do espaço urbano se fortalecem no espaço comum.

sobre a ideologia, o fim da falsa consciência comum ou o fim de uma intenção comum

O paralelismo entre ideologia e esquizofrenia estabelecido por Gabel (La Fausse conscience) deve ser compreendido nesse processo econômico de materialização da

\footnotetext{
2 No livro "O Canteiro e o Desenho", Sérgio Ferro faz uma análise crítica da produção do espaço numa micro-escala. Especificamente, ele observa como 0 arquiteto se insere nesta produção espacial no canteiro e no desenho. Apoiado nas idéias de Marx, Ferro percorre todo o livro ilustrando e explicando das mais diversas formas que o desenho tornou-se um instrumento essencial à obtenção da mais-valia pela alienação e separação do trabalho dado no canteiro. Ferro adota o termo 'idiotização' do trabalho e mostra como 0 arquiteto foi se distanciando cada vez mais do canteiro enquanto desenvolvia uma linguagem abstrata para a produção num sistema de trabalho idiotizado. Mais adiante, Ferro mostra como a separação do trabalho pelo desenho se volta contra o próprio arquiteto, prisioneiro da sua própria invenção. Assim, Ferro coloca o arquiteto numa encruzilhada onde pode-se partir para um desenho mais consciente ou continuar-se alienado sendo apenas mais um instrumento do processo reprodutivo do capital. Na verdade, ao analisar 0 processo produtivo da arquitetura, Ferro sugere que 0 arquiteto desenhe a produção ao invés de desenhar para a produção. E é acreditando nesta idéia que Ferro desenvolve os argumentos do seu texto para embasá-la e explica-la.
}

Dentro desta perspectiva histórica o arquiteto e o urbanista se afasta cada vez mais do canteiro, da obra, dos processos produtivos e desenvolve um método de produção do espaço que é baseada numa abstração que é o próprio desenho. A perspectiva busca a realidade, e hoje, os modelos virtuais dos computadores concebem espaços com tal perfeição que chegam a ser chamados de "realidade" (realidade virtual). Não aprofundando muito nas questões do virtual, mas para efeito deste texto baseando-se nas reflexões de Paul Virilio, vamos perceber que de virtual estes espaços não tem nada e de real muito menos. Trata-se de uma alienação espacial, de uma alienação dos processos de produção do espaço, e finalmente uma alienação do espaço socialmente produzido caracterizado por Lefebvre. 0 texto do Sérgio Ferro ainda que carregado de ideologias e estruturalismos abre uma crítica quanto ao processo de produção espacial até então pouco discutida na arquitetura. 
ideologia. 0 que a ideologia já era, a sociedade tornou-se. A desinserção da práxis, e a falsa consciência antidialética que a acompanha, eis o que é imposto em cada momento da vida cotidiana sujeita ao espetáculo; eis o que é preciso compreender como uma organização sistemática da "falha da faculdade de encontro", e como sua substituição por um fato alucinatório social: a falsa consciência do encontro, a 'ilusão do encontro'. Numa sociedade em que ninguém consegue ser reconhecido pelos outros, cada indivíduo torna-se incapaz de reconhecer sua própria realidade. A ideologia está em casa; a separação construiu seu próprio mundo. (DEBORD, 1997:139-140)

As ideologias totalizantes ${ }^{3}$, principalmente as que emergiram no século XIX contaram com a força de muitos intelectuais fomentando a concepção do projeto moderno. Ideologias totalizantes que buscavam a emancipação humana, a verdade e uma sociedade mais certeira com um futuro melhor.

Hoje as ideologias estão exaustas, perderam a sua capacidade de persuasão, perderam sua força. A dissolução da União Soviética, a abertura da China e a resistência de Cuba elucidam bem este cenário. É fácil ilustrar a ideologia totalizadora no socialismo, entretanto, como a ideologia se apresentou no ocidente capitalista? Ela se apresentou no Welfare State (o estado do bem estar social) e no sistema produtivo FordistaKeynesiano. "As ideologias do século XIX eram universais, humanistas e elaborada por intelectuais. As ideologias de massa da Ásia e da África são provincianas, instrumentais e criadas por líderes políticos". (caso da China) (BELL, 1962: 403) "O que movia as ideologias antigas era a igualdade social e, num sentido ampliado, liberdade. 0 impulso das novas ideologias são o desenvolvimento econômico e o poder nacional." (BELL, 1962:

${ }^{3}$ Abordando uma outra análise referente a ideologia necessária a complementação desta reflexão, cito o texto de Daniel Bell, 'The End of Ideology in The West: A Epilogue' do livro 'The End of Ideology' (1960).

"A palavra ideologia foi cunhada pelo filósofo francês Destutt de Tracy no fim do século XVIII. Juntamente com outros filósofos iluministas, de Tracy tentava descobrir a 'verdade' como alternativa à fé e a autoridade, métodos tradicionais encorajados pela igreja e pelo estado. (...) e esta nova ciência de idéias foi chamada 'ideologia'. A conotação negativa deste termo surgiu com Napoleão. Consolidando seu poder, ele proibiu o ensino de ciência moral e política no Instituto nacional e denunciou os 'ideólogos' como especuladores irresponsáveis que subvertiam a moral e o patriotismo. Enquanto republicano, Napoleão foi simpático às idéias dos filósofos; enquanto imperador, ele reconheceu a importância da ortodoxia religiosa na manutenção do estado. Mas foi com Marx que a palavra 'ideologia' passou por curiosas transmutações. Para Marx, assim como em seu trabalho 'A Ideologia Alemã', ideologia estava ligada ao idealismo filosófico, ou a concepção de idéias autônomas, e estas idéias, independentemente, têm o poder de revelar verdade e consciência." (BELL, 1962: 395)

"Então, por exemplo, seguindo Feuerbach - de quem Marx tirou a maior parte de suas análises de ideologia e alienação - ele considerou religião como falsa consciência: desuses são a criação da mente humana e eles aparecem somente para existir independentemente e para determinar a fé do homem; religião logo é uma ideologia. Marx ainda deu um passo mais adiante. Ideologias, disse ele, não são somente idéias falsas, mas eles mascaram interesses particulares. Ideologias declaram ser a verdade, mas refletem necessidades de grupos específicos." (BELL, 1962: 396) "O 'desmascaramento' de uma ideologia, entretanto, é revelar o interesse 'objetivo' por trás da idéia e verificar a que função a ideologia serve." (BELL, 1962: 397)

Bell diferencia uma distinção, baseando-se em Manheim, entre 'a concepção particular de ideologia' e a concepção total de ideologia'. Uma concepção particular pode ser a partir de interesses específicos como por exemplo interesses econômicos.

"Quando Charles E. Wilson, o Secretário de Defesa durante a administração de Eisenhower e presidente da General Motors, disse, 'O que é bom para os Estados Unidos é bom pra a General Motors, e vice-versa,' ele estava expressando uma ideologia - i.e., a visão de que a política econômica deveria ser engrenada às necessidades da comunidade econômica, considerando que o bem-estar social do país dependia da saúde dos negócios." (BELL, 1962: 399) "Uma ideologia 'total' é um sistema de realidade abrangente, é um conjunto de crenças, introduzido com entusiasmo, que busca transformar a totalidade do modo de vida. Este cometimento ideológico - a busca por uma causa, ou a satisfação de desejos morais profundos - não é necessariamente o reflexo de interesses no campo das idéias. Ideologia, neste sentido, e no sentido que usamos aqui é uma religião secular." (BELL, 1962: 400) (grifo nosso) 
403) O plano de metas de JK e o milagre econômico na época da ditadura é um exemplo deste momento ideológico no Brasil. O resultado deste processo culminou nos anos 70-80 com o fim do welfare state nos paises desenvolvidos e uma estagnação econômica nos paises em desenvolvimento.

Bell descreve a exaustão das ideologias políticas no século XX que acrescido do cenário políticoeconômico-cultural colocado por Harvey (1989) veremos que a passagem para o sistema de acumulação flexível do capital (HARVEY, 1989) coincide com o momento em que as ideologias se perdem nos fragmentos e na instabilidade deste novo sistema. Se voltarmos à questão que nos interessa, podemos verificar como o modernismo foi profundamente impulsionado pelas ideologias político/econômicas do século XX. Como o urbanismo, institucionalizado no século XX também foi uma ideologia. Hoje percebemos claramente a exaustão destas ideologias no colapso das formas culturais produtivas modernistas.

Voltando à ideologia segundo Debord, verificamos a construção de um conceito bem diferente da concepção clássica dos filósofos franceses e também, bem diferente da de Marx. É uma concepção da ideologia espetacular, uma ideologia fragmentada, - "a ideologia está em casa; a separação construiu seu próprio mundo." (DEBORD, 1997:140) - uma ideologia efêmera. Autônoma (descontrolada), transitória e fugidia que se transforma o tempo todo sob um sistema condicionado por fatores que escapam do campo das idéias, ou seja, condicionado pelo próprio espetáculo. Talvez o fim da ideologia prenunciado por Bell não tenha sido consumado, pelo menos não da forma como ele previa. Hoje temos o fim da ideologia enquanto o fim de uma retórica; o fim das metanarrativas, da busca constante por verdades eternas e imutáveis, o fim do entusiasmo no futuro e porque não dizer o fim de uma intenção comum. 
1.1.1.

o urbano e o modo de vida comum [ encontros e desencontros ]

1. o espaço comum

1.1. sobre o espaço comum

1.1.1. o urbano e o modo de vida comum [ encontros e desencontros ]

1.1.2. tempo de diversão [ playtime ]

1.1.3. espaço, paisagem e eventos [ dogville ] 


\section{o urbano}

Lefevbre fala de um fenômeno urbano ao estudar o conjunto de transformações que a sociedade contemporânea atravessa. Ele aborda o termo urbano desdobrando-o no conceito sociedade urbana propondo um esquema conceitual, atemporal e u-tópico que se distancia do real sem perder a realidade de vista. Neste seu esquema, ele propõe um processo de transformação que vai desde a ausência completa de urbanização (a pura natureza, a terra entregue aos elementos) à culminação do processo. Este seu esquema é um eixo espacial porque o processo se estende no espaço que ele modifica e consequentemente, enquanto espaço produzido é necessariamente dotado do tempo. Sendo assim, qualquer sociedade, qualquer época em qualquer estágio deste processo pode ser encaixada em algum momento deste processo que é uma face do próprio processo de modernização4.

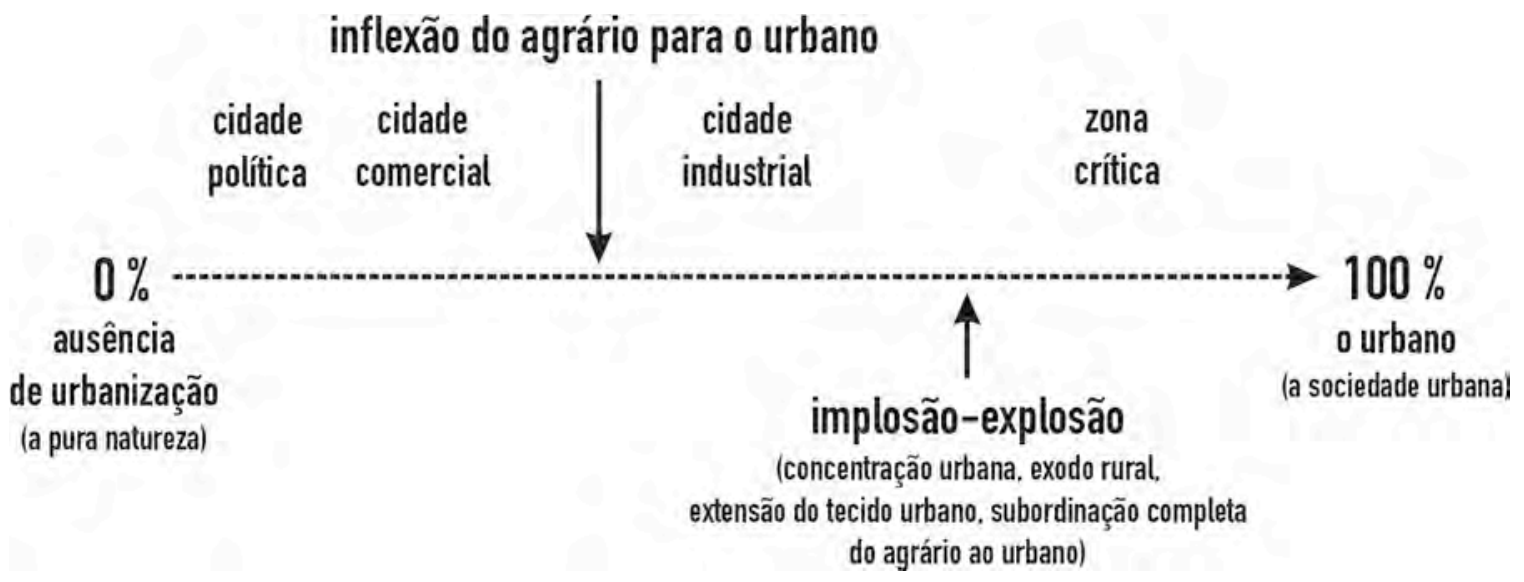

fig.3. esquema teórico de Henri Lefebvre (LEFEBVRE, 2004, pg. 27)

O urbano define-se portanto não como realidade acabada, situada, em relação à realidade atual, de maneira recuada no tempo, mas, ao contrário, como horizonte, como virtualidade iluminadora. O urbano é o possível, definido por uma direção, no fim do percurso que vai em direção a ele. (LEFEBVRE, 2004, pg. 26, grifo nosso)

Lefebvre considera a sociedade urbana como uma virtualidade. Seu fim não é um ideal, é um sentido, uma direção, um processo contínuo. Esta abordagem está aberta a qualquer interferência do acaso, aberto às situações fugidias e transitórias da modernização. Desta forma, Lefebvre também consegue se afastar dos conceitos ideológicos que influenciaram boa parte da produção acadêmica sobre o urbanismo.

Do mesmo modo, em seguida, utilizando-se as palavras 'revolução urbana', designaremos o conjunto das transformações que a sociedade contemporânea atravessa para passar do período em que predominam as questões de crescimento e de industrialização (modelo, planificação, programação) ao período no qual a problemática urbana prevalecerá

${ }^{4}$ O subitem 1.1.2 tempo de diversão [ playtime ], abordará o tempo moderno, pós-moderno e hipermoderno caracterizando 0 processo de modernização. 
decisivamente, em que a busca das soluções e das modalidades próprias à sociedade urbana passará ao primeiro plano. (LEFEBVRE, 2004, pg. 19)

Dentro deste eixo espacial e temporal de consolidação de uma sociedade urbana ou do urbano Lefebvre aponta um momento de inflexão, um momento de crise, a fase crítica do processo na qual ele desdobra seu estudo.

O que se passa durante a fase crítica? Esta obra tenta responder a esta interrogação, que situa a problemática urbana do processo geral. As hipóteses teóricas que permitem traçar um eixo, apresentar um tempo orientado, transpor a zona crítica pelo pensamento, indo além dela, permite apreender o que se passa? Talvez. Já podemos formular algumas suposições. (LEFEBVRE, 2004, pg. 27)

"Para mostrar a profundidade da crise, a incerteza e a perplexidade que acompanha a 'fase crítica', pode-seefetuar uma confrontação." (LEFEBVRE, 2004, pg. 29) Neste momento, Lefebvre começa a confrontar argumentos de vários autores e pensadores que se posicionam a favor e contra a rua, a favor e contra 0 monumento, a favor e contra o urbanismo, a favor e contra o centro urbano, etc. Neste confronto, Lefebvre é imparcial e expõe claramente que qualquer posição pode vir acompanhada de argumentos bastante justos e coerentes. Apoiado no que discutimos, quem sustentava o argumento verdadeiro ou o correto (o eterno e imutável), eram as ideologias totalizadoras. 


\section{o urbanismo como modo de vida}

Resgatando alguns conceitos, gostaria de retomar um pouco as idéias da Escola de Chicago, especialmente o texto de Louis Wirth O Urbanismo como Modo de Vida publicado originalmente em 1938.

As reflexões da Escola de Chicago têm uma importância fundamental para 0 urbanismo. Como participantes de um contexto de crescimento explosivo e descontrolado das cidades industriais americanas no início do século XX, sociólogos iniciam uma reflexão do que veio a ser chamado sociologia urbana. A escola de Chicago foi pioneira nas reflexões que tratam das relações sociais na cidade industrial - 0 urbanismo.

Wirth chama atenção para as transformaç̧̃es dos modos de vida dos grupos humanos que surgem com a cidade industrial.

A característica marcante do modo de vida do homem na idade moderna é a sua concentração em agregados gigantescos em torno dos quais está aglomerado um número menor de centros e de onde irradiam as idéias e as práticas que chamamos civilização. (...) As influencias que as cidades exercem sobre a vida social do homem são maiores do que poderia indicar a proporção da população urbana, pois a cidade não somente é, em graus sempre crescentes, a moradia e o local de trabalho do homem moderno. (WIRTH, 1973, pg. 90)

Wirth acredita que a cidade é um produto de um crescimento e não uma criação instantânea, aqui temos um paralelo com Lèfebvre que mais tarde expõe este processo enquanto uma produção social do espaço. "Então, deve-se esperar que as influências que a cidade exerce sobre os modos de vida não sejam capazes de eliminar completamente os modos de associação humana que predominavam anteriormente" (WIRTH, 1973, pg. 91). A cidade é o ponto de aglomeração das relações que impulsionam as sociedade. Logo este ponto de ligação comum entre as diversas atividades produzidas num espaço (urbano) se estende além dos limites do que podemos definir como cidade.

Além do mais, podemos inferir que a vida rural levará a marca do urbanismo, à medida que sofre a influência das cidades através de contato e comunicação. Poderá servir de contribuição para o esclarecimento das declarações que se seguem, repetirmos que, embora o local do urbanismo como um modo de vida deva, evidentemente, ser achado caracteristicamente em localidades que preenchem os requisitos que estabeleceremos para a definição de cidade, o urbanismo não está confinado a tais localidades, mas manifesta-se em graus variáveis onde quer que cheguem as influências das cidades. (WIRTH, 1975, pg. 95, grifo nosso)

Wirth chama atenção para sermos cautelosos na definição de cidade que é caracterizada por questões culturais locais e condicionantes históricos enquanto que o urbanismo é uma relação que se dá num espaço que vai além dos limites do lugar citadino. "[...] Enquanto a cidade é o local característico do urbanismo, o modo de vida urbano não se confina às cidades. [...]" (WIRTH, 1973, pg. 112) O urbanismo é um modo de vida, trata-se 
de uma relação entre indivíduos que surge com a industrialização e se espelha além dos limites das cidades industriais chegando a afetar inclusive o modo de vida rural.

Os vínculos de parentesco, de urbanidade e os sentimentos característicos da vida em conjunto durante gerações sob uma tradição 'folk' comum tenderão a desaparecer e, no melhor dos casos, tenderão a ser fracos num agregado cujos membros apresentam origens e formação tão diversas." (WIRTH, 1973, pg. 99) (...) "Numa comunidade composta de grande número de indivíduos que não se conhecem intimamente e cujo número é excessivo para se reunirem num só lugar, torna-se necessário efetuar a comunicação por meios indiretos e articular interesses individuais por um processo de delegação. Especificamente na cidade, os interesses são efetivados através de representação. (WIRTH, 1973, pg. 102, grifo nosso)

Logo as relações que se dão num aglomerado urbano criam linguagens por um processo de representação que permitem uma inter-relação entre indivíduos que não se conhecem e sem nenhuma relação de parentesco. O modo de vida rural ou tradicional, que Wirth chama de folk foi transformado na cidade industrial. Nela surge uma outra forma de relação entre grupos de indivíduos. A família, as relações de parentesco tendem a perder importância na cidade industrial, principalmente na grande cidade e na metrópole.

As relações entre indivíduos passam a acontecer no campo das representações, aqui Wirth sugere um embrião do que Debord veio mais tarde a discutir enquanto uma sociedade do espetáculo.

Para Wirth o urbanismo é uma forma de organização social, daí modo de vida. E seus traços característicos seriam:

Os traços característicos do 'modo de vida' urbano têm sido descritos sociologicamente como consistindo na substituição de contatos primários por secundários, no enfraquecimento dos laços de parentesco e no declínio do significado social da família, no desaparecimento da vizinhança e na corrosão da base tradicional da solidariedade social. (WIRTH, 1973, pg. 109)

A vida econômica autônoma ou de subsistência, característica de uma sociedade rural é alternada por uma vida econômica interdependente. "Como um todo, a cidade desencoraja uma vida econômica na qual o indivíduo, numa época de crise, tenha uma base de subsistência à qual recorrer, e desencoraja o emprego autônomo." (WIRTH, 1973, pg. 110) A partir desta observação, sociólogos da Escola de Chicago desenvolvem uma teoria chamada ecologia urbana ou ecologia humana. Esta teoria pressupõe que "reduzido a um estágio de virtual impotência como indivíduo, o habitante urbano esforça-se para fazer parte de grupos organizados de interesses semelhantes para obter seus fins." (WIRTH, 1973, pg. 110) Análogo à ecologia de ambientes naturais tais como ecosistemas específicos a ecologia humana "[...] envolve um grau de interdependência maior entre os homens e uma forma mais complicada, frágil e volátil de inter-relações mútuas sobre muitas fases das quais 0 indivíduo como tal não consegue exercer quase nenhum controle. [...]" (WIRTH, 1973, pg. 110) 
Os grandes números são responsáveis pela variabilidade individual, pela relativa ausência de conhecimento pessoal íntimo, pela segmentação das relações humanas as quais são em grande parte anônimas, superficiais e transitórias e por características correlatas. A densidade envolve diversificação e especialização, a coincidência de contato físico estreito e relações sociais distantes, contrastes berrante, um padrão complexo de segregação, a predominância do controle social formal, e atrito acentuado, entre outros fenômenos. A heterogeneidade tende a quebrar estruturas sociais rígidas e a produzir maior mobilidade, instabilidade e insegurança, e a filiação de indivíduos e a uma variedade de grupos sociais opostos e tangenciais com um alto grau de renovação dos seu componentes. (...) $\mathrm{O}$ indivíduo, portanto, somente se torna eficaz através de grupos organizados. (WIRTH, 1973, pg. 113) 


\section{o modo de vida metropolitano}

Completando um pouco mais as colocações de Wirth, o texto A Metróple e a Vida Mental de Georg Simmel ${ }^{5}$ apresenta uma outra abordagem para a compreensão das relações entre indivíduos no meio urbano. Simmel diz que:

[...] a mente moderna se tornou mais e mais calculista. A exatidão calculista da vida prática, que a economia do dinheiro criou, corresponde ao ideal da ciência natural: transformar o mundo num problema aritimético, dispor todas as partes do mundo por meio de fórmulas matemáticas. (SIMMEL, 1973, pg. 14)

O desenvolvimento da cultura moderna é caracterizado pela prepoderância do que poderia chamar de o 'espírito objetivo' sobre o 'espírito subjetivo'. (SIMMEL, 1973, pg. 23, grifo nosso)

Logo qualquer valor cultural subjetivo que não se encaixasse nos fins universais do projeto moderno era menosprezado. A conseqüência desta postura foi o "retrocesso na cultura do indivíduo com relação a espiritualidade, delicadeza e idealismo" (SIMMEL, 1973, pg. 23).

Essa discrepância resulta essencialmente da crescente divisão de trabalho. Pois a divisão de trabalho reclama do indivíduo um aperfeiçoamento cada vez mais unilateral. E um avanço grande no sentido de uma busca unilateral com muita freqüência significa a morte para a personalidade do indivíduo. Em qualquer caso, ele cada vez menos pode equipararse ao supercrescimento da cultura objetiva. (SIMMEL, 1973, pg. 23, grifo nosso)

"O indivíduo tornou-se um mero elo em uma enorme organização de coisas e poderes que arrancam de suas mãos todo o progresso, espiritualidade e valores, para transformá-los de sua forma subjetiva na forma de uma vida puramente objetiva. (SIMMEL, 1973, pg. 23)

Segundo Simmel a vida torna-se fácil para a personalidade da pessoa que os estímulos, interesses, uso do tempo livre, consciência são dados pelo espírito objetivo, "[...] atrofia da cultura individual através da hipertrofia da cultura objetiva [..]" (SIMMEL, 1973, pg. 24). Assim a pessoa é conduzida numa corrente coletiva onde a busca pela autenticidade é uma opção desnecessária (ver seleção de cenas do filme Fight Club de David Fincher no DVD-Rom). Mas isto não impede que haja correntes alternativas e "[...] isso resulta em que 0 indivíduo apele para o extremo no que se refere à exclusividade e particularização, para preservar sua essência mais pessoal. [...]" (SIMMEL, 1973, pg. 24).

A questão do gosto individual passou a ser notada e relevante no início do século XX, principalmente para os economistas neoclássicos que procuravam - sob argumentos questionáveis - a satisfação de gostos individuais e não mais a imposição de um gosto coletivo. A particularidade passa a ser explorada pela economia,

5 Georg Simmel (1858-1918) foi um dos maiores colaboradores da ciência social, seu trabalho apresentou importantes contribuições para a reflexão da construção social do espaço. Simmel, também, está entre os pensadores que mais influenciaram a Escola de Chicago. 
a pesquisa de público alvo, do consumo dirigido, etc. Trata-se de uma individualidade cultural segmentada em nichos em que o espírito objetivo é fragmentado e apresentado sob um aspecto aparentemente individualizado.

O espírito objetivo pode ser entendido como uma abordagem da alienação de Marx sob o ponto de vista do comportamento e da personalidade do indivíduo urbano. Mais tarde Debord retoma os conceitos alienação e separação sob outro ponto de vista. Não mais visto sob a divisão do trabalho no processo produtivo industrial e nem somente sob o modo de vida urbano, mas do ponto de vista da inter-relação entre indivíduos dada pela representação - a sociedade do espetáculo - algo que Wirth já sugeria no seu texto de 1938. 


\section{o modo de vida comum [encontros e desencontros]}

O encontro de estranhos é um evento sem passado. Freqüentemente é também um evento sem futuro (o esperado é não ter futuro), uma história para não ser continuada. (Bauman 2001, pg. 111)

Em Modernidade Líquida (2001) Bauman aborda as diversas formas que caracterizaram a passagem do capitalismo pesado ao capitalismo leve e da modernidade sólida à fluida. Bauman nos fala de uma individualização baseada em um culto ao consumo. Fala da profusão de não-lugares e espaços vazios que são os lugares onde estranhos se encontram. Talvez uma das melhores representações destas características descritas por Bauman seja o filme Encontros e Desencontros (Lost in Translation, 2003) de Sofia Coppola. É um tempo e um espaço múltiplo dado à imensa fragmentação das relações espaço/tempo da nossa sociedade. Se o tempo ${ }^{6}, 0$ espaço, as relações, o trabalho e o lazer estão contidos numa constante transformação condicionada pela efemeridade e transitoriedade, pelo instantâneo dos meios de comunicação e pela velocidade dos meios de transporte, podemos dizer que a modernidade é a mesma, mas é vivida por modos completamente opostos aos modos do início do século XX.

Podemos entender a sociedade urbana de Lefebvre, o urbano, como um sistema contínuo de interrelações (ecologias), produção e reprodução (consumo) onde o indivíduo atua em modos de vida - modos comportamentais - mediados por representações. Se as ecologias, as formas de produção e reprodução (consumo) e os meios de representação estão em constante processo de transformação (transitório e efêmero), sem um tempo preciso, sem um espaço definido, nada rígido (flexível), insólido. Se tudo pode ser rearranjado a qualquer momento, podemos adotar a metáfora de que nosso modo de vida está submerso num meio líquido onde tudo é instável, tudo é instantâneo, tudo é a-espacial e a-temporal.

O modo de vida comum é moderno por estar baseado nos condicionantes modernistas, entretanto assume uma outra ordem. A partir da própria modernização do sistema urbano a sua participação exige um modo de vida diferenciado uma participação tão fluída e líquida quanto o sistema vigente. Logo o modo de vida contemporâneo é da ordem do indivíduo multi-especializado, apto a assumir qualquer tarefa a qualquer instante e ter vários empregos (ou trabalhos). É um modo onde o tempo-espaço do lazer, consumo e trabalho se fundem e se confundem numa completa liquidificação dos espaços e tempos de vida, a vida pública se dissolveu em uma sobreposição de privados, uma mistura heterogênea conflitante e desconfortável de líquidos privados derramados em uma superfície de batalha.

${ }^{6}$ a questão tempo, especificamente os tempos moderno, pós-moderno e hiper-moderno são tratados no subitem 1.1.2 tempo de diversão [ playtime ] . 


\section{considerações finais}

Se as condições de modernização nunca mudaram, porque podemos afirmar que o modo de vida é outro? Porque não é o mesmo? Como vimos na teoria de Harvey, Bell, Lefebvre, Debord entre outros, os preceitos para se viver e experimentar o processo de modernização era tomados por ideais. Somados às tentativas de lidar com a modernização (a reação cultural modernista), haviam vários procedimentos que ofuscaram o que realmente era o processo modernizador. A própria busca por uma grande verdade era a perfeita construção de uma mentira, uma alienação, um distanciamento da realidade, uma artificialização da situação.

A busca pelo espírito objetivo em detrimento do espírito subjetivo eram formas de camuflar um processo iniciado com a modernização que apresentava conseqüências opostas ao que havia sido idealizado (eterno e imutável). O projeto de modernização, muito bem intencionado, se revelou às avessas. Uma reversão completa. Uma perfeita contradição. A contradição moderna está na sistematização de um processo aberto a transformações naturalmente não-reguláveis e simultaneamente querer que isto tudo possa ser regulado (controlado). É um processo sujeito a desvios, imprevisibilidades, e momentos caóticos assim como a natureza.

A modernização ${ }^{7}$ é um processo contínuo naturalmente desregulado (portanto um sistema - dito é seu sistema > o capitalismo) é um processo natural da natureza humana. É a completa consolidação do ambiente humano com todas as ecologias que Ihe são possíveis. É o oposto da formação de um ambiente de idéias (ideológico) se aproximando mais um ambiente natural - da natureza humana - com todas as suas conseqüências imprevisíveis, doentias, psicosintomáticas, caóticas, frágeis, acidentais, ... 
1.1.2.

tempo de diversão [ playtime ]

1. o espaço comum

1.1. sobre o espaço comum

1.1.1. o urbano e o modo de vida comum [ encontros e desencontros ]

1.1.2. tempo de diversão [ playtime ]

1.1.3. espaço, paisagem e eventos [ dogville ] 


\section{o tempo no mundo moderno}

A modernidade (ou o projeto moderno) é uma transformação social, produtiva e cultural que se iniciou no iluminismo, consolidou-se na revolução industrial e desde então, como diz Harvey, vivemos em um turbilhão processual que se apresenta ora inacabado, ora em ascensão, ora em colapso, ora superado, etc. Cada autor dá a sua interpretação para este processo, são opiniões diversas e muitas vezes opostas. Não cabe aqui discutir e muito menos tomar partido de alguma destas opiniões. 0 que nos interessa é o próprio processo. Tomamos como ponto de partida o turbilhão apontado por Harvey e tiramos algumas questões para se refletir das contradições deste processo.

Esta dissertação pretende construir um momento (um tempo), um momento atual onde o modo de vida é a questão chave. Nesta construção, a teoria da acumulação flexível de Harvey será uma das bases para as questões que serão colocadas. O Urbanismo como Modo de Vida de Louis Wirth, O Fim da Ideologia de Bell, A Sociedade do Espetáculo de Debord, A Modernidade Líquida de Bauman e A Metrópole e a Vida Mental de Simmel também são contribuições teórico/conceituais importantes.

\section{caracterizando o processo de modernização}

A modernidade é a "ruptura com todas e quaisquer condições históricas precedentes, caracterizada por um interminável processo de rupturas e fragmentações internas inerentes". (HARVEY, 1999, pg. 22) Logo a "modernidade não pode respeitar sequer o seu próprio passado... a transitoriedade das coisas dificulta a preservação de todo sentido de continuidade histórica." (HARVEY, 1999, pg. 22) Deste modo, "[...] os pensadores iluministas acolheram o turbilhão da mudança e viram a transitoriedade, 0 fugidio e o fragmentário como condição necessária por meio da qual o projeto modernizador poderia ser realizado. [...]" (HARVEY, 1999, pg. 23, grifo nosso).

A imagem da 'destruição criativa' é muito importante para a compreensão da modernidade, precisamente porque derivou dos dilemas práticos enfrentados pela implementação do projeto modernista. Afinal, como poderia um novo mundo ser criado sem se destruir boa parte do que viera antes? (HARVEY, 1999, pg. 26)

As figuras históricas que melhor exemplificam esta imagem são as intervenções de Haussman em Paris e de Robert Moses em Nova Iorque.

Segundo Harvey, podemos entender a modernidade como um processo contínuo e caótico, um turbilhão. Um processo condicionado pela transitoriedade, pelo fugidio e pelo fragmentário. Sendo que as intenções deste processo de modernização, seu objetivo - a emancipação humana e o enriquecimento da vida 
diária - se daria ao ser revelado as qualidades universais eternas e imutáveis, a meta narrativa, a grande verdade. Logo;

[...] nessa nova concepção do projeto modernista, artistas, escritores, arquitetos, compositores, poetas, pensadores e filósofos tinham uma posição bem especial. Se o 'eterno e imutável' não mais podia ser automaticamente pressuposto, o artista moderno tinha um papel criativo a desempenhar na definição da essência da humanidade. Se a 'destruição criativa' era uma condição essencial da modernidade, talvez coubesse ao artista como indivíduo uma função heróica (mesmo que as conseqüências pudessem ser trágicas). (HARVEY, 1999, pg. 27e 28)

[...] se 0 fluxo e a mudança, a efemeridade e a fragmentação formavam a base material da vida moderna, então a definição de uma estética modernista dependia de maneira crucial do posicionamento do artista diante desses processos. (HARVEY, 1999, pg. 29)

É importante ter em mente, portanto, que o modernismo surgido antes da Primeira Guerra Mundial era mais uma reação às novas condições de produção (a máquina, a fábrica, a urbanização), de circulação (os novos sistemas de transportes e comunicações) e de consumo (a ascensão dos mercados de massa, da publicidade, da moda de massas) do que um pioneiro na produção dessas mudanças. Mas a forma tomada pela reação iria ter uma considerável importância subseqüente. Ela não apenas forneceu meios de absorver, codificar e refletir sobre essas rápidas mudanças, como sugeriu linhas de ação capazes de modifica-las ou sustenta-las. (HARVEY, 1999, pg. 32)

Nota-se que as bases de modernização impulsionam reações de posturas diversas e até mesmo opostas. Diante desta diversidade, então, o modernismo - um movimento cultural reacionário a estes processos é um movimento conceitualmente divergente por estar baseado em uma contradição que é explicitada numa pergunta colocada por Harvey: "Mas como, em meio a todo o caos, representar o eterno e o imutável?" (HARVEY, 1999, pg. 30) Ou seja como em meio de um processo condicionado pelo efêmero e fugidio (caos) podemos buscar o eterno e imutável (as grandes verdades ou as meta narrativas). 0 modernismo, enquanto movimento inserido dentro do processo de modernização (modernidade), é uma resistência cultural de crise contínua por estar apoiado numa contradição.

Baseado neste posicionamento teórico de Harvey, que coloca o modernismo enquanto movimento cultural inserido num processo social, tecnológico e político, podemos observar algumas propostas sintomáticas e emergentes do início do século XX de produtores culturais ${ }^{8}$ e planejadores que vislumbraram uma cidade eterna e imutável, uma cidade baseada numa narrativa única, numa grande verdade. Trazendo a discussão um pouco mais próxima do que interessa neste trabalho podemos apontar algumas ilustrações. A Feira Mundial de Nova lorque em 1939, por exemplo, é um momento excelente para podemos avaliar este processo pelos seguintes motivos:

${ }^{8}$ quando me referencio a produtores culturais, incluo arquitetos, urbanistas, designers, escritores, músicos e artistas que também podem ser vistos como planejadores e produtores da cidade e que possuem como finalidade primeira a produção e/ou crítica de formas de relação social, modos e comportamentos. Prefiro usar o termo produtores culturais a fim de separá-los dos planejadores e produtores da cidade que tem como finalidade primeira a reprodução dos meios de produção da cidade: políticos, administradores, industriais, técnicos, engenheiros, etc. 
- Assim como a feira de Nova lorque, outras feiras também ficaram às margens da história e da crítica da produção artístico cultural. Por ter um fim industrial (uma feira mais de planejadores do que de produtores culturais), são raros os momentos que as feiras são citadas nas reflexões críticas da produção cultural do século XX.

- Por ser uma exposição de caráter industrial/produtivo e tecnologias, uma feira com tendências de consumo, consequentemente é uma feira que reflete modos de vida e comportamentos de uma sociedade. Aqui temos uma expressão sintomática do turbilhão. Uma expressão inocente e alienada, um excelente contraponto aos relatos históricos e críticos da produção cultural do século XX. Ou seja, um momento para se fazer um contraponto entre produtores culturais e planejadores.

O Futurama (pavilhão da GM) e a Democratic City são bons exemplos do que era mostrado nestas feiras, uma prospecção da cidade num futuro próximo, com vias de trânsito rápido, com sistemas de transporte automatizados e eficientes. Uma cidade articulada em torno de fluxos constantes demandava um novo sistema de aeroporto, terminais de carga e complexos industriais. A arquitetura do espaço comum era um elemento sem muita importância perto da infra-estrutura fragmentária e da funcionalidade do desenho da nova cidade. 0 Futurama e a Democratic City eram desenhos que abordavam não somente as possibilidades tecnológicas e de consumo de uma cidade, mas também, inocentemente um desenho de comportamento humano, uma completa subversão do modo de vida urbano em prol de um modo de vida modernizado, automatizado. Solà-Morales quando faz uma análise crítica dos processos de representação a fim de entender e associá-lo ao que foi produzido coloca:

A substituição das vistas e perspectivas da grande cidade por imagens aéreas está ligada diretamente a sua condição fragmentária, estendida por um território somente abarcado a partir de pontos de vista situados fora da visada convencional e em um jogo de abstrações e figurações que a fotomontagem já havia explorado tão eficazmente. As imagens aéreas da cidade, não somente as que fascinaram Le Corbusier, (...), eram uma mescla de planos geométricos, de visões insólidas e associações construtivas propiciadas pelo reconhecimento icônico de alguns elementos asilados em meio de paisagens cada vez mais abstratas. (SolàMorales, 2002, pg. 67 e 68)

O Futurama era concebido como um brinquedo de parque de diversões que convidava o visitante a sobrevoar a cidade do futuro. $\mathrm{O}$ visitante se assentava numa cadeira que percorria o pavilhão sobrevoando a maquete da cidade enquanto se ouvia uma voz que dizia:

... 1960 . here's an American city, planed around a highly developed modern traffic system, the rights of way has been so rooted as to displace outmoded business sections and undesirable slum areas whenever possible. A vast circular airport is close to the city, with a giant dirigible hangar so that it can be turn easily to meet any wind direction. It's resting in a pool of liquid. Here's a highway intersection. Highway engineering at it's most spectacular by means of the ramps and loops. Cars may make right and left turn at rates of sped up to 50 miles/h. Safe distances between cars is maintained by automatically radio control. It also assists the driver with keeping the car in proper lane under all circumstances. Here are skyscrapers towers, on many of these buildings are landing decks for helicopters. We seen 
some suggestions of what to come. A world with a future which all of us are tremendly interested. Because that is where we are going to spend the rest of our lives. ${ }^{9}$

Esta transcrição da narração introdutória do vídeo The World of Tomorrow mostra claramente as intenções dos planejadores daquela época, particularmente dos planejadores por trás da indústria automobilística. Por mais que se negue este tipo de planejamento espetacularizado por um amusement de uma feira e não oficializado por uma produção cultural, é inegável a participação deste planejamento na produção das cidades do século XX em todo o mundo.

Outro ponto curioso é a própria representação do futuro. O futuro, o desenho do futuro é uma evidência muito expressiva entre os anos 20 e 60, e foi justamente no momento em que o modernismo, enquanto movimento cultural, consolidou-se de forma generalizada em todo o mundo. As freqüentes representações do futuro eram uma forma de congelar o tempo, um tempo tão rápido (fugidio) que para ser eternizado precisa ser representado no futuro, é uma revolução, um crescimento, um desenvolvimento presente tão entusiástico que 0 futuro é uma alternativa para eternizá-lo.

A Futuro House ${ }^{10}$ é outro exemplo da tentativa de se congelar o tempo e eternizar as características fugidias e transitórias da modernidade. Uma casa sem lugar e sem tempo, (uma casa que assume os condicionantes da modernização transitório + fugidio), pronta para ser implantada e consumida em qualquer situação a qualquer momento. Livre de quaisquer condições históricas, culturais e sociais precedentes e que busca qualidades universais eternas e imutáveis.

Harvey destaca esta questão que confronta a representação aos condicionantes da modernização dizendo:

\footnotetext{
9 texto extraído do video: "The World of Tomorrow" (1984) Produced and Directed by Tom Johnson and Lance Bird. Narrated by Jason Robards. Written by John Crowley. Edited by Kate Hirson. Black and White and Color. 78 minutes.

"Elegiac and unsettling ... The film celebrates American pluck as much as it is wistful about our naivete, leaving us with a wealth of ideas and no neat message."

Tom Johnson and Lance Bird will present the world premiere of The World of Tomorrow, their feature-length documentary about the great New York World's Fair of 1939. Begun in 1979, the film is made up entirely of material from the thirties, including home movies, newsreels, industrial and promotional films, cartoons, still photographs and other vintage graphics which portray the Art Deco extravaganza that was the World's Fair. Aided by a team of scholars, the filmmakers have evoked that moment when the world stood poised between black-and-white and color, between the Depression and the War. Since the whole Fair offered a look at Tomorrow and then documented the effort on film, The World of Tomorrow also offers a look back into the future.
}

The World of.,Tomorrow will open theatrically at Film Forum in New York City and will be broadcast nationally on PBS. The film is a project of the American Portrait production unit of Media Study/Buffalo and received funding from the New York State Council on the' Humanities and the Pew Memorial Trust.

Tom Johnson is former Director of the Graduate Program for Media Study at Antioch College. He has extensive film and television credits, having worked as a producer and director on projects for the Corporation for Public Broadcasting, Westinghouse Broadcasting Company, and Time/Life Films. Lance Bird has served as a producer, director, and consulting producer for PBS, Time/Life Films, and HBO, among others. [fonte: http://www.vasulka.org/archive/4-30c/MediaStudy(6029).rtf]

${ }^{10}$ Anexo no fim da dissertação ilustrações do projeto da Futuro House. 
[..] 0 artista, 0 arquiteto e 0 escritor tinham que encontrar alguma maneira especial de representá-los. [...] o modernismo se preocupava com a linguagem, com a descoberta de alguma modalidade especial de representação de verdades eternas. A realização pessoal dependia da inovação na linguagem e nas formas de representação [...]. Mas se a palavra era de fato fugidia, efêmera e caótica, o artista tinha, por essa mesma razão, de representar 0 eterno através de um efeito instantâneo, tornando "a tática do choque e a violação das continuidades esperadas" vitais para fazer chegar ao destino a mensagem que 0 artista procurava transmitir. 0 modernismo só podia falar do eterno ao congelar o tempo e todas as suas qualidades transitórias. (HARVEY, 1999, pg. 30, grifo nosso)

A generalização do modernista no mundo conquistou sua hegemonia no período pós-guerra. E esta hegemonia assume um papel organizador político, principalmente do ponto de vista econômico. A produção cultural neste momento tem um papel fundamental na consolidação e reorganização das sociedades do pósguerra.

Enquanto o modernismo dos anos entre - guerras era "heróico" mas acossado pelo desastre, o modernismo 'universal' ou 'alto' que conseguiu hegemonia depois de 1945 exibia uma relação muito mais confortável com os centros de poder dominantes da sociedade. A contestada busca de um mito apropriado pareceu receder em parte, suspeito eu, porque 0 sistema de poder internacional - organizado, como veremos na parte II, ao longo de linhas fordistas-keynesianas, sob os olhos vigilantes da hegemonia norte-americana - se tornou relativamente estável. A arte, a arquitetura, a literatura etc. do alto modernismo tornaram-se artes e praticas do estabilishment numa sociedade em que uma versão capitalista corporativa do projeto iluminista de desenvolvimento para o progresso e emancipação humana assumiria o papel de dominante político-econômica. (HARVEY, 1999, pg. 42)

O modernismo oportunamente assume um papel para rapidamente reconstruir as relações sociais e produtivas do pós-guerra.

[...] a arquitetura resultante apenas produzia impecáveis imagens de poder e de prestígio para corporações e governos conscientes da publicidade, enquanto desenvolvia projetos modernistas de habitação popular que se tornaram "símbolos de alienação e de desumanização". Mas também é possível dizer que, se desejavam encontrar soluções capitalistas para os dilemas do desenvolvimento e da estabilização político-econômica do pósguerra, era necessário algum tipo de planejamento e industrialização em larga escala na indústria da construção, aliado à exploração de técnicas de transporte de alta velocidade e de desenvolvimento de alta densidade. Em muitos desses aspectos, 0 alto modernismo teve bastante sucesso. (HARVEY, 1999, pg. 42)

Entretanto este papel oportunista do modernismo não teve o mesmo sucesso no desenho do espaço comum, do espaço urbano e dos espaços do cotidiano do indivíduo urbano.

Seu real lado inferior estava, sugiro, em sua celebração subterrânea do poder e da racionalidade burocráticos corporativos, sob o disfarce de um retorno ao culto superficial da máquina eficiente como mito capaz de encerrar todas as aspirações humanas. $\mathrm{Na}$ arquitetura e no planejamento, isso significava desprezar o ornamento e a personalização (a ponto dos inquilinos das casas públicas não poderem modificar o ambiente para atender a necessidades pessoais e de os alunos que viviam no Pavilhão Suíço de Le Corbusier terem de torrar todos os verões porque o arquiteto se recusava, por razões estéticas, a permitir a instalação de persianas. (HARVEY, 1999, pg. 42 e 43, grifo nosso) 
A arte e a alta cultura se tornaram uma reserva tão exclusiva de uma elite dominante que a experimentação no seu âmbito (com, por exemplo, novas formas de perspectivismo) ficou cada vez mais difícil, exceto em campos estéticos relativamente novos como o cinema. Pior ainda, parecia que essa arte e essa cultura não podiam senão monumentalizar o poder corporativo ou estatal, ou o "sonho americano", como mitos auto-referenciais, projetando um certo vazio de sensibilidade no lado da formulação de Baudelaire que se apoiava nas aspirações humanas e nas verdades eternas.

Foi esse o contexto em que os vários movimentos contraculturais e antimodernistas dos anos 60 apareceram. Antagônicas às qualidades opressivas e da racionalidade técnico-burocrática de base científica manifesta nas formas corporativas e estatais monopolíticas e em outras formas de poder institucionalizado, as contraculturas exploram os domínios da autorealização individualizada por meio de uma política distintivamente "neo-esquerdista" da incorporação de gestos antiautoritários e de hábitos iconoclastas (na música, no vestuário, na linguagem e no estilo de vida) e da crítica da vida cotidiana. (HARVEY, 1999, pg. 44, grifo nosso)

Alguns destes movimentos contraculturais antimodernistas dos anos 60 trazem à tona uma reflexão crítica sobre a vida cotidiana e a produção dos espaços urbanos. Destaco a Internacional Situacionista e as contribuições de Guy Debord e Henri Lefebvre. Este movimento desencadeou uma crítica ao urbanismo e ao modo de vida com uma outra abordagem para se ver o mundo e seu processo de modernização, entender sua produção e propor novas formas de apreendê-las. Um exemplo é Manuel Castells, ex-aluno de Lefebvre, que na década de 70 veio a contribuir com o urbanismo trazendo à tona uma crise conceitual ao apontar boa parte dos estudos em urbanismo como uma ideologia urbanística que se distanciava da realidade. Sua crítica acerca do espaço urbano publicado em A Questão Urbana iniciou diversos estudos sobre 0 urbanismo a partir dos movimentos sociais urbanos e das suas relações de reprodução (consumo). Jane Jacobs e Richard Sennett também são autores que na mesma época colocam em questão o urbanismo e o modo de vida modernos, estes podem ser considerados os primeiros textos do urbanismo pós-estruturalista (FAINSTEIN, 1997, pg. 26) ${ }^{11}$ representado hoje, principalmente, pelos escritos de Michael Sorkin, Neil Smith, Edward W. Soja, Trevor Boddy, Mike Davis e M. Christine Boyer apenas para citar alguns.

Trazendo uma ilustração deste movimento de contracultura, destaco o filme Play Time ${ }^{12}$ (1967) de Jaques Tati' ${ }^{13}$. Filmado entre 1964 e 1967, este filme de Tati juntamente com Meu Tio (Mon Oncle, 1958) e As Férias do Sr. Hulot (Les Vacances de Monsieur Hulot, 1953) desmonta e critica uma série conceitos modernos. Satirizando com muito humor a vida moderna formalizada e padronizada (grandes verdades - metanarrativas), Tati transforma o cotidiano mostrado no filme num espetáculo. Neste cenário, Tati satiriza o urbanismo moderno onde se (re)produzem comportamentos ridículos e absurdos. O filme mostra seu personagem principal, Sr.Hulot,

11 FAINSTAIN, Susan. 1997. "Justice, Politics and The Creation of Urban Space". In: MERRIFIELD, A.; SWYNGEDOUW, E. 1997. "The Urbanization of Justice". New York: New York University Press. p. 18-44

${ }^{12}$ Anexo no fim da dissertação fotografias do cenário de Jaques Tati, fotografias de frames do filme e no DVD-Rom uma seleção de cenas relacionadas aos temas discutidos pelo movimento modernista.

13 Play Time (1967) Jacques Tati. (http://www.tativille.com) ver também: VILCHES, Gloria Fernández. "La ciudad moderna en Mon Oncle y Playtime Una aproximación a Jacques Tati" in: http://www.otrocampo.com/8/tati.html 
desorientado diante da moderna burocratização do cotidiano. Em geral o filme Playtime critica a arquitetura e 0 planejamento modernista (Le Corbusier 1943 - Carta de Atenas e o estilo internacional) que dividia a vida do cidadão em quatro funções: trabalhar, habitar, desfrutar do seu tempo livre e circular (esta última, com lugares específicos na cidade, é uma forma imprescindível de articular os espaços especializados das três primeiras funções).

Um momento marcante do filme, com explícita referencia ao estilo internacional, está nos cartazes de destinos turísticos internacionais onde cartazes com fotos de edifícios estilo internacional se repetem quer sejam os destinos. Vale destacar que parte da narrativa do filme aborda um grupo de turistas americanos em visita a Paris. As imagens características de Paris como a Torre Eiffel o Arco do Triunfo e a Sacre Coeur aparecem eventualmente em reflexos dos vidros da Paris moderna.

É na espetacularização da vida cotidiana que seu filme banaliza toda a ordem espacial do cotidiano moderno apresentando-o como se fosse uma grande brincadeira em um parque de diversões. Um contraponto à critica do filme e uma excelente descrição social deste momento é a de Debord no livro "A Sociedade do Espetáculo" (1967) com a primeira edição no mesmo ano de lançamento deste filme:

Toda a vida das sociedades nas quais reinam as modernas condições de produção se apresenta como uma imensa acumulação de espetáculos. Tudo o que era vivido diretamente tornou-se representação." (DEBORD, 1997, pg. 13, grifo nosso) "O espetáculo não é um conjunto de imagens, mas uma relação social entre pessoas, mediada por imagens." (DEBORD, 1997, pg. 14) "O espetáculo é o capital em tal grau de acumulação que se torna imagem. (DEBORD, 1997, pg. 25)

O filme de Tati em diversos momentos pode ser usado para ilustrar os textos de Debord, por exemplo:

O tempo gasto nos transportes, como bem observou Lê Corbusier, é um sobre trabalho que reduz a jornada de vida chamada livre. Precisamos passar do transito como suplemento do trabalho ao transito como prazer. (DEBORD, Is $n$ 3, dezembro de 1959)

É freqüente a crítica que Tati faz ao transito em seus filmes. O final de Playtime, por exemplo, Tati transforma o engarrafamento de uma rotatória num parque de diversões.

Quando a produção cultural cede à instabilidade e às qualidades fugidias da modernização, um outro momento se inicia, coincidentemente, e muito bem teorizado por Harvey, é uma transição que coincide com uma alteração dos modos de produção e reprodução do capital - o novo padrão flexível de acumulação. Mais uma vez, assim como o modernismo veio carregado de ideologias que apoiaram uma nova estruturação econômico/produtiva do capitalismo ocidental (fordismo-keynesianismo) o pós-moderno é uma dominante cultural do capitalismo tardio (JAMESON, 2002, pg. 72), consequentemente uma ideologia de uma sociedade de consumo dirigido. Aqui temos um novo momento onde as contradições inerentes ao processo de modernização são celebradas. 
[...] Começo com o que pode ser mais espantoso sobre o pós-modernismo: sua total aceitação do efêmero, do fragmentário, do descontínuo e do caótico que formavam uma metade do conceito baudelairiano de modernidade. Mas o pós-modernismo responde a isso de uma maneira bem particular; ele não tenta transcende-lo, opor-se a ele e sequer definir os elementos 'eternos e imutáveis' que poderiam estar contidos nele. 0 pósmodernismo nada, e até se espoja, nas fragmentárias e caóticas correntes da mudança, como se isso fosse tudo o que existisse. (HARVEY, 1999, pg. 49, grifo nosso) 


\section{o tempo de diversão [ playtime ]}

Uma recente interpretação deste processo de transformação, melhor explicitado como reação cultural, é a de Gilles Lipovetsky. Ele parte do "advento de uma temporalidade social inédita, marcada pela primazia do aqui-agora" (LIPOVETSKY, 2004, pg. 51) e diz que "no momento em que triunfam a tecnologia genética, a globalização liberal e os direitos humanos, o rótulo pós-moderno já ganhou rugas, tendo esgotado sua capacidade de exprimir o mundo que se anuncia." (LIPOVETSKY, 2004, pg. 52)

A partir dos anos 70 , a noção de pós-modernidade fez sua entrada no palco intelectual com o fim de qualificar o novo estado cultural das sociedades desenvolvidas. (...) ela bem depressa foi mobilizada para designar ora 0 abalo dos alicerces absolutos da racionalidade e o fracasso das grandes ideologias da história, ora a poderosa dinâmica de individualização e de pluralização de nossas sociedades. Para além das diversas interpretações propostas, impôs-se a idéia de que estávamos diante de uma sociedade mais diversa, mais facultativa, menos carregada de expectativas em relação ao futuro. As divisões entusiásticas do progresso histórico sucediam-se horizontes mais curtos, uma temporalidade dominada pelo precário e pelo efêmero. (LIPOVETSKY, 2004, pg. 51)

A questão tempo passa a ser o meio para interpretar uma sociedade que ele chama de hipermoderna.

Entretanto ele reconhece uma contribuição do pós-moderno (segundo Lipovestky, 'neologismo pós-moderno');

[...] salientar uma mudança de direção, uma reorganização em profundidade do modo de funcionamento social e cultural das sociedades democráticas avançadas. Rápida expansão do consumo e da comunicação de massa; enfraquecimento das normas autoritárias e disciplinares; surto de individualização; consagração do hedonismo e do pscicologismo; perda da fé no futuro revolucionário; descontentamento com as paixões políticas e as militâncias - era mesmo preciso dar um nome a enorme transformação que se desenrolava no palco das sociedades abastadas, livres do peso das grandes utopias futuristas da primeira modernidade. (LIPOVETSKY, 2004, pg. 52, grifo nosso)

Ao mesmo tempo a expressão pós-moderno era ambígua, desajeitada, para não dizer vaga. Isso porque era evidentemente uma modernidade de novo gênero a que tomava corpo, e não uma simples superação daquela anterior. (LIPOVETSKY, 2004, pg. 51, grifo nosso)

Neste momento de transformação, Lipovetsky sugere um novo arranjo do regime do tempo social onde podemos encontrar:

(I) a passagem do capitalismo de produção para uma economia de consumo e de comunicação de massa; e (II) a substituição de uma sociedade rigorístico-disciplinar por uma 'sociedade-moda' completamente reestruturada pelas técnicas do efêmero, da renovação e da sedução permanentes. (LIPOVETSKY, 2004, pg. 60)

Num cenário veloz, onde o presente está sempre em fuga, o futuro pouco importa. Não é uma prática social construir hoje para o futuro. Todos nós somos seduzidos permanentemente pelo efêmero em tempos de diversão. 
questões de colapso (início e fim)

Se a única coisa certa sobre a modernidade é a incerteza, devemos sem dúvida dar considerável atenção às forças sociais que produzem tal condição. (HARVEY, 1999, pg. 113, grifo nosso)

Questões de colapso podem ser usadas para abordar uma coleção de recortes sobre o processo de modernização. Podemos falar de um colapso de horizontes temporais (Harvey), de uma implosão da vida pública (Caldeira), do fim das ideologias (Bell), do fim do espaço público (Sorkin), uma alteração de comportamento (Jameson), da sociedade pós-industrial (Bell), do urbanismo em fim de linha (Arantes), de um espaço crítico (Virilio), de uma pós-metrópole (Soja), de uma crise das matrizes espaciais (Duarte) e do declínio do homem público (Sennett) apenas para citar alguns. Entretanto o que nos interessa não é ressaltar o colapso, o colapso aqui não é relevado à concepção de fim, processo terminal. Este colapso pode ser entendido, baseado nas reflexões de Harvey e Lipovetsky, enquanto um momento de afloramento de uma crise que é contínua e inerente ao processo de modernização.

Quanto menos o futuro é previsível mais ele precisa ser mutável, flexível, reativo, permanentemente pronto a mudar, supermoderno, mais moderno que os modernos dos tempos heróicos. A mitologia da ruptura radical foi substituída pela cultura do mais rápido e do sempre mais: mais rentabilidade, mais desempenho, mais flexibilidade, mais inovação. (LIPOVETSKY, 2004, pg. 57) 
1.1.3.

espaço, paisagem e eventos [ dogville ]

1. 0 espaço comum

1.1. sobre o espaço comum

1.1.1. o urbano e o modo de vida comum [ encontros e desencontros ]

1.1.2. tempo de diversão [ playtime

1.1.3. espaço, paisagem e eventos [ dogville ] 


\section{$[\ldots]$}

2nd SCENE: - NIGHT. SEASON: EARLY SPRING 2

\section{NARRATOR}

Despite considerable effort on his part to prolong things, Tom had achieved the triumph at the checkerboard pretty quickly. It had started to rain and the wind had become a regular gale when Tom strolled home through Elm Street.

If Tom were to prove that the citizens of Dogville had a problem receiving in his lecture the next day... he sorely lacked an illustration... a gift... Bill might have been right it hadn't exactly rained gifts on this particular township.

\section{NARRATOR}

There was no doubt in his mind. They were gun shots. The pile driver in the marshes didn't sound like that at all. The shots had come from down in the valley, or perhaps from Canyon Road some place in the direction of Georgetown. He listened for more shots for ages. But they were not repeated. A tad disappointed, Tom sat down on the old lady's bench to think. To hang onto the feeling of danger for a moment. But it wasn't long before his thoughts were back on his favorite subjects again, and in the midst of the storm they metamorphosed into articles and novels and great gatherings that'd listen in silence to Tom after the publication of yet another volume that scourged and purged the human soul. And he saw men - and among them even other writers - throw their arms round one another as, through his words, life had opened up for them anew. It hadn't been easy. But by his diligence and application to narrative and drama his message had gotten through, and asked about his technique he would have to say but one word: "lllustration".

NARRATOR (cont'd)

Tom could have spent another half hour or more on the bench, but another unusual noise roused him. It was Moses barking. Oh, that wasn't unusual in itself, but it was the way he barked that was new. His barking was not loud, but more of a snarl, as if the danger was quite close at hand and not merely a passing raccoon or fox. As if the dog were standing face to face with a force to be taken seriously.

TOM

Hey Lady! I wouldn't go up there if I were you. I know the mountain well, I doubt if I'd get away with my life. It's a very nasty drop.

GRACE

Is there another way?

TOM

Yeah.

GRACE

Where?

TOM

Back down the way you came from. Back down to Georgetown. Why do you need to get out of the mountain? Did you have anything to do with those gunshots? 
Help me, help me please!

TOM

You can hide in the mine, in there!

DRIVER

Hey where's this road headed to?

TOM

No where, it's a dead end, if you want to pass, turn around go back by way of Georgetown, this place uh it's called Dogville.

\section{DRIVER}

Dogville? Well it figures, it's a stupid name if I ever heard one. Hey we're look'n for somebody...

TOM

Oh really, who might that be?

$[\ldots]$

(VON TRIER, Lars. DOGVILLE. 2003) 


\section{considerações iniciais}

O presente texto pretende delimitar um conceito de espaço enquanto instrumento operativo para este trabalho. Após pesquisar diversas referências, conceitos e teorias, agrupamos e relacionamos as idéias que contribuíram para delimitar o espaço da ação, da prática e das experiências que serão aplicados no desenvolvimento desta pesquisa. As referências vieram de geógrafos, sociólogos e filósofos dentre os quais destaco as contribuições fundamentais para este trabalho de Henri Lefebvre, Paul Virillio e Milton Santos.

Talvez, o objetivo principal deste trabalho seja aproximar-se de uma abordagem conceitual e ao mesmo tempo instrumental de espaço que possa ser aplicada a pratica da arquitetura, do urbanismo e do design. Então, no desenvolver desta questão podemos perceber:

- quais são as características e/ou definições de espaço às quais vamos nos referir/adotar?

- que categorias e/ou instrumentos teórico-metodológicos do espaço são referências deste trabalho?

\section{do espaço idealizado ao espaço sensível}

Frequentemente dicionários tentam definir o espaço como algo com uma 'extensão ilimitada...'. A própria quantificação de 'ilimitado' parece ter sido tomada como alternativa à uma impossibilidade definidora. Parece quase nada querer dizer. E no entanto diz; e o diz com a clara intenção de que a infinitude atrelada à incompletude do espaço se mantenha. (DUARTE, 2002, pg. 30)

Definir espaço é uma tarefa um pouco complexa e a princípio sem propósito. Entretanto, em meio a esta impossibilidade definidora podemos colocar alguns conceitos que podem ser úteis neste momento para um fim específico. Logo, o objetivo aqui é tentar conceituar e delimitar a questão espacial contribuindo para a construção do objeto desta dissertação que é o espaço comum. Diversas formas de se conceituar e definir 0 espaço podem ser encontrados na física, na filosofia, na sociologia e na geografia. Os conceitos e definições dos geógrafos parecem mais adequados à discussão da arquitetura e do urbanismo uma vez que seu campo de ação se assemelha à do arquiteto e urbanista abrangendo questões filosóficas e sociais num contexto material (físico), logo, são conceitos e definições que aglutinam as questões espaciais físicas - a materialidade do mundo (biologia, geologia, etc.), e as questões espaciais culturais - a imaterialidade do mundo (sociologia, filosofia, etc.)

Duarte (2002), resgata algumas definições de espaço em diversos momentos sob duas óticas distintas; o espaço postulado e o espaço produzido. Duarte coloca que "[...] o espaço infinito foi descrito não por ter sido constatado, mas postulado. 0 conceito do espaço não mais correspondia ao vivido, mas ao que poderia ser formulado através da linguagem científica [...]" (DUARTE, 2002, pg. 30). Sendo assim, neste espaço infinito e 
incorpóreo onde está o homem? ${ }^{14}$ Por outro lado, o espaço produzido introduzido por Henri Lèfebvre pressupõe um corpo, considerado ao mesmo tempo sujeito e objeto.

O espaço postulado é um ideal moderno. É um espaço onde o corpo não existe, um vazio. Mesmo na arquitetura, nas suas origens (modernas), o espaço não era uma questão que inquietava seus pensadores; 0 termo espaço (spatium) não aparece nos primeiros tratados de arquitetura de Vitrúvius e Alberti, por exemplo, e continuou ausente até o século XX.

“... então, a teoria da arquitetura lidava com proporções, harmonia, conveniência, efeito, ordem e distribuição de seus elementos, sendo que seus problemas eram resolvidos fundamentalmente através do desenho. Tal ausência do trato direto do espaço na arquitetura é realmente espantosa e foi ressaltada por Henri Lefebvre (1981:312-313), que considera capital a obra de Vitrúvio como um tratado de semiologia aquitetônica, mas que falta um dado, para ele fundamental, na constituição do espaço: 0 efeito urbano, sem o qual não existe qualquer possibilidade de se falar em espaço cívico, em espaço como algo vivido coletivamente." (DUARTE, 2002, pg. 30 e 31, grifo nosso)

Este espanto ressaltado por Lefebvre foi muito bem caracterizado por Sergio Ferro ${ }^{15}$ ao fazer uma análise crítica da posição do arquiteto entre 0 canteiro e o desenho. Ferro mostra 0 distanciamento do arquiteto da práxis - que é o canteiro - até sua completa alienação produtiva no desenho. Ferro mostra como as questões do espaço, ressaltadas com espanto por Lefebvre, foram sendo deixadas gradualmente de lado. 0 desenho como mostra Ferro foi um instrumento de alienação do arquiteto da prática, do cotidiano e conseqüentemente do espaço urbano. Trata-se da criação de um instrumento (des)sensibilizador de questões sociais urbanas. Um instrumento que esvazia o espaço de seu conteúdo essencial, o corpo.

Lefebvre, filósofo francês que se dedicou à crítica à vida cotidiana e aos modos de vida da sociedade moderna desenvolveu uma teoria sobre a produção social do espaço, uma teoria que se afastava um pouco da visão estruturalista Marxista, sem negá-la, entretanto compreendendo uma diversidade de fatores que os estruturalistas deixavam escapar. Lefebvre considerando o espaço de convívio coletivo - o espaço comum elabora uma teoria da produção do espaço social, ou seja, o espaço socialmente produzido.

A primeira noção de espaço que gostaríamos de adotar nesta dissertação seria a noção de um espaço sensível, um espaço em que o corpo do homem se faz presente. Um espaço que não é idealizado, mas um

14 "A definição ontológica do espaço como sendo infinito e incorpóreo (Abbagnand, 1971) é recorrente no desenvolvimento das ciências e da filosofia modernas, passando pelas obras de Newton e conseqüentes, até início do século XX. [...] 0 corpo considerado ao mesmo tempo "sujeito" e "objeto", sem poder ser separado em conceitos distintos, não se encaixaria na exatidão do pensamento filosófico e científico nascente. Poder-se-ia perguntar: nesse espaço infinito e incorpóreo, onde colocar o corpo humano? Henri Lefebvre (1981:467) alerta para a abolição do corpo que se instaurava no pensamento ocidental, considerando-a como traição filosófica. Jan Marajko (1994: 29-30) ainda observa que se é necessária a alienação do sujeito do objeto observado para se chegar a uma definição precisa, se todos os cientistas decidissem se retirar do espaço para defini-lo, ninguém e nada mais restaria no mundo. É o mundo histérico do homem histérico, aquele que não sabe mais o que fazer com seu corpo, imaginando-se fora de qualquer enraizamento espaço-temporal." (DUARTE, 2002, pg. 30 e 31, grifo nosso) 
espaço que é vivido. Para trabalhar com estes espaço é necessário uma sensibilização, uma percepção que pressupõe um processo muito distante do ideal moderno e distanciado de espaço.

\section{o espaço segundo Milton Santos}

O brasileiro Milton Santos contribuiu significativamente para o pensamento geográfico e convergiu questões e interesses multidisciplinares para se pensar uma nova geografia. Elaborou questões que são discutidas não somente por geógrafos, mas também por artistas, arquitetos, urbanistas, planejadores, filósofos, economistas, políticos, educadores, etc.

Destaco a relação entre o pensamento de Santos e Lefebvre fato é que acontecerá um paralelo entre os dois aqui. Nos seus textos, apesar de não se referir diretamente a Lefebvre, salvo em bibliografia, Santos o referência e vai mais além com as questões sócio-espaciais. Santos também se destaca pela clareza e objetividade na organização de seus argumentos, seu compromisso enquanto educador. Já Lefebvre não é tão claro e objetivo, mas seus textos abrem questões muito mais complexas e sempre nos convida a uma releitura.

É interessante notar que quando Santos trás para a questão espacial as ações e os fluxos e Lefebvre trás a práxis do cotidiano uma outra questão vem a reboque; o tempo. 0 tempo talvez seja uma das principais diferenças entre o espaço postulado idealizado, neste não cabe o corpo que trás consigo as dinâmicas - fluxos, ações e práxis. Einstein argumentou cientificamente uma relação de equivalência entre espaço e tempo e a que a separação dos dois só seria possível por meios postulados - um ideal dado, uma mentira.

Destaco alguns trechos dos textos de Santos no qual ele procura inquietantemente uma definição instrumental, esta definição passa por diversos momentos e termina em um ponto que tornou-se fundamental para este trabalho que é a distinção entre espaço, espacialidades (eventos) e paisagem. Os momentos em que Santos tenta explicar o espaço são os seguintes:

- Momento 1: fixos e fluxos (as configurações do território)

- Momento 2: sistema de objetos e sistema de ações (o sistema contraditório)

- Momento 3: o tempo (os eventos) e o espaço

- Momento 4: a distinção entre paisagem e espaço

Momento 1: fixos e fluxos (as configurações do território)

Os elementos fixos, fixados em cada lugar, permitem ações que modificam o próprio lugar, fluxos novos ou renovados que recriam as condições ambientais e as condições sociais, e redefinem cada lugar. Os fluxos são um resultado direto ou indireto das ações e atravessam ou instalam nos fixos, modificando a sua significação e o seu valor, ao mesmo tempo em que, também, se modificam. (Santos, 2002, pg. 61 e 62) 
Argumentando que os fixos estão cada vez mais; artificiais e fixados ao solo; os fluxos são cada vez mais diversos, mais amplos, mais numerosos, mais rápidos; Santos aponta uma outra possibilidade; trabalhar com outro par de categorias; a configuração territorial e as relações sociais.

A configuração territorial é dada pelo conjunto formado pelos sistemas naturais existentes em um dado país ou numa dada área e pelos acréscimos que os homens superimpuseram a esses sistemas naturais. A configuração territorial é dada pelo conjunto formado pelos sistemas naturais. A configuração territorial não é o espaço já que sua realidade vem de sua materialidade e a vida que a anima. (SANTOS, 2002, pg. 62, grifo nosso)

Note que Santos destaca que a configuração territorial não é o espaço. A configuração territorial é um resultado de uma ação; de uma vida que a anima. Aqui, Santos já chama atenção para a importância dos fluxos e das relações sociais que dão vida e animam a materialidade. Sem negar seu valor, estas categorias espaciais ainda são conceitos pouco plausíveis para a discussão que estamos propondo, então seguiremos para um próximo momento onde estes conceitos serão ampliados e melhor explorados pelo autor.

Momento 2: sistema de objetos e sistema de ações (o sistema contraditório)

O espaço é formado por um conjunto indissociável, solidário e também contraditório, de sistemas de objetos e sistemas de ações, não considerados isoladamente, mas como 0 quadro único no qual a história se dá.

[...]

Sistemas de objetos e sistemas de ações interagem. De um lado, os sistemas de objetos condicionam a forma como se dão as ações e, de outro lado, o sistema de ações leva à criação de objetos novos ou se realiza sobre objetos preexistentes. É assim que o espaço encontra a sua dinâmica e se transforma. (SANTOS, 2002, pg. 63)

Santos desenvolve as categorias do primeiro momento, inclusive, tornando-as mais claras. Entretanto, o que queremos destacar aqui, além do desenvolvimento do pensamento e da gradual elucidação das idéias, é a permanência da:

- interação ou interdependência que o leva a usar o termo sistema

- importância do elemento gerador, da ação que dinamiza e transforma.

A noção de sistema é muito oportuna pois o sistema pressupõe uma estrutura não rígida e não linear. Um sistema está apto a condicionar e a ser condicionado, ou seja o sistema pré-supõe uma constante transformação na sua estrutura, uma adequação que se dá a cada momento em que se faz necessário uma mudança. 0 espaço é uma relação dinâmica entre sistemas que se interagem e se transformam continuamente. 


\section{Momento 3: a distinção entre paisagem e espaço}

Num terceiro momento, Santos insere neste raciocínio espacial uma categoria instrumental comum à geografia, à arquitetura e ao urbanismo - a paisagem. Neste caso, Santos volta ao primeiro momento ampliando a noção de configuração territorial.

A paisagem é o conjunto de formas que, num dado momento, exprimem as heranças que representam as sucessivas relações localizadas entre homens e natureza. O espaço são essas formas mais a vida que as anima. (SANTOS, 2002, pg. 103)

Santos afirma que a paisagem não é espaço, sendo assim, "[...] a paisagem é transtemporal, juntando objetos passados e presentes, numa construção transversal. O espaço é sempre um presente, uma construção horizontal, uma situação única. [...]" (SANTOS, 2002, pg. 103).

Ainda segundo Santos, podemos dizer que a paisagem é relativa ao material, um sistema material e 0 espaço à ação que a dinamiza e a transforma, um sistema de valores ${ }^{16}$. 0 espaço é dotado de tempo, é sempre um presente porque sua dinâmica temporária não contém uma interrupção. A paisagem pode ser de um tempo outro que não o presente. Se não é presente, logo a paisagem é referente a algo passado. A paisagem enquanto passado pode ser perfeitamente desprovida de um tempo contínuo, sem a dimensão temporal. Entretanto a paisagem mesmo que passado, quando se faz presente é espaço. Isto nos aponta para a hipótese de que a paisagem enquanto passado congelada e imutável é algo que não existe pois a paisagem sempre está pronta para receber as ações dinamizadoras do espaço e ser transformada.

Santos aproxima o espaço do cotidiano urbano ao afirmar que o espaço é a sociedade. E a partir deste momento podemos falar de uma paisagem humana. Aqui também podemos fazer um paralelo a Lefebvre que fala insistentemente da relação de uma sociedade e de um corpo social na produção do espaço.

Segundo C. Reboratti (1993, p.17) 'a paisagem humana é uma combinação de vários tempos presentes'. Na verdade, paisagem e espaço são sempre uma espécie de palimpsesto onde, mediante acumulações e substituições, a ação das diferentes gerações se superpõe. O espaço constitui a matriz sobre a qual as novas ações substituem as ações passadas. É ele, portanto, presente, porque passado e futuro. (SANTOS, 2002, pg. 103 e 104, grifo nosso)

A paisagem é um instrumento para entender o espaço e tratar suas questões, "[...] a paisagem é apenas uma abstração, Apesar de sua concretude como coisa material. Sua realidade é histórica e lhe advém de sua associação com o espaço social. [...]" (SANTOS, 2002, pg. 108) Santos incita a hipótese de que a paisagem não existe, na realidade, a paisagem é um produto, uma abstração criada pelo homem que o permite

${ }^{16}$ A paisagem é, pois, um sistema material e, nessa condição, relativamente imutável: o espaço é um sistema de valores que se transforma permanentemente." (SANTOS, 2002, pg. 103) 
falar, perceber e analisar o espaço. A paisagem é uma construção histórica e é através dela que nós podemos estudar 0 espaço.

Momento 4: o tempo (os eventos) e o espaço

A palavra evento pode ter diferentes acepções e ser usada em multiplos sentidos.

[...] nos dicionários filosóficos, o que aqui estamos considerando como evento aparece, também, com outros nomes. Cada autor qualifica o vocábulo no interior do seu sistema de idéias. Onde Lefebvre escreve a palavra 'momento', Bacherlard fala de 'instante' e Whitehead de 'ocasião'. Já para Russel $(1948,1966$, p.289), um evento resulta de uma série de instantes. Assim a sinonímia não é exata, mas a construção de uma teoria geográfica do evento pode utilizar tais vocábulos quase indiferentemente. É preciso, porém, que a teoria geográfica seja internamente coerente e, desse modo, atribua um valor próprio a esses termos. (SANTOS, 2002, pg. 143 e 144)

A questão do presente $\mathrm{x}$ passado no que ser refere ao espaço e a paisagem é retomada aqui por Santos. Santos considera que os eventos são todos presente, "Eles acontecem em um dado instante, uma fração de tempo que eles qualificam. Os eventos são, simultaneamente, a matriz do tempo e do espaço." (SANTOS, 2002, pg. 145, grifo nosso)

\section{Na verdade os eventos mudam as coisas, transformam objetos, dando-lhes, ali mesmo onde estão, novas características. [...] \\ Não há evento sem ator. Não há evento sem sujeito, lembra-nos C. Diano (1994, p.66). Nesse sentido toda teoria da ação é, também, uma teoria do evento e vice-versa. (SANTOS, 2002, pg. 146 e 147)}

Santos também considera que os eventos também são idéias e não apenas fatos (SANTOS, 2002, pg. 148). O evento possui uma duração, uma extensão, escala e superposições. O evento é sempre presente, mas o presente não é o instantâneo, daí a idéia de duração. E se há uma duração poderemos ter eventos que acontecem simultaneamente, eventos que podem acontecer simultaneamente inclusive num mesmo lugar, daí a superposição. Um evento pode ter uma escala, uma escala de abrangência local e até mesmo mundial.

Sistematizando um pouco a idéias colocadas por Santos sem tentar tirar uma conclusão definitiva e muito menos única das idéias contidas neste texto coloco a distinção entre paisagem, espacialidade e espaço ilustrado pela fúrmula abaixo:

\section{[paisagem $x$ espacialidades (eventos) $x$ espaço]=espaço}

Esta fórmula diagramática é uma ilustração de um entendimento colocado por Santos. 0 espaço é 0 resultado de uma dinâmica constante entre paisagem e eventos - uma multiplicando a outra - e ainda assim o 
espaço tem uma função multiplicadora nesta dinâmica, ou seja o espaço também altera 0 resultado desta dinâmica, sendo a assim o espaço nunca é constante, está sempre em transformação.

paisagem

"A rigor a paisagem é apenas a porção da configuração territorial que é possível abarcar com a visão". (SANTOS, 2002, pg. 103) Mas Santos trás uma nova reflexão acerca da paisagem pode ser mais que isso. A paisagem é o que podemos ver, mas ela trás consigo algumas características essenciais à compreensão do espaço.

É interessante como Santos coloca a questão da paisagem como um momento histórico temporal, logo a paisagem é um passado, um fato histórico e o espaço é sempre presente. "A paisagem é história congelada, mas participa da história viva." (SANTOS, 2002, pg. 107, grifo nosso) Ou seja a paisagem, ainda que faça parte de um espaço (que é sempre presente) é passado. A paisagem é um resultado final do acúmulo de presentes que coexistem no espaço.

A paisagem diz respeito às coisas e aos objetos. Podemos considerar a paisagem como um resultado e ao mesmo tempo condicionante material do espaço numa construção transversal e transtemporal como coloca Santos:

A paisagem se dá como conjunto de objetos reais-concretos. Nesse sentido a paisagem é transtemporal, juntando objetos passados e presentes, uma construção transversal. 0 espaço é sempre um presente, uma construção horizontal, uma situação única. (SANTOS, 2002, pg. 103, grifo nosso)

\section{o espaço socialmente produzido}

Se o espaço é sempre o presente, e baseando-se nas teorias de Santos que se referem aos espaços, concluímos que ele é um sistema de objetos (os fixos). É interessante notar a evolução do conceito de santos de fixos para sistema. 0 sistema é uma abordagem conceitual muito mais completa do espaço presente e é 0 que Lefebvre busca detalhar em sua obra "The Production of Space" (1974). Lefebvre percebe que o espaço é um meio-estrutural, um sistema onde os objetos estão aptos a serem formados e (re)formados (produzidos, reproduzidos e transformados) por uma estrutura, um sistema que é genuinamente social. Daí a dialética lefebvriana sócio-espacial. A dialética é inseparável pois sem o social, estaríamos falando do espaço sem tempo e sem o corpo (tempo + corpo $=$ ação). 0 espaço socialmente produzido de Lefebvre é o que ele considera como espaço. Porque quando este espaço socialmente produzido modifica seus objetos num ciclo contínuo (re)transformando constantemente sua estrutura é que realmente reconhecemos nele as características de um sistema. Um sistema está sempre aberto a mudanças e a alterações estruturais. Se o espaço é sempre presente, se é o sistema de produção social do espaço, precisamos de uma fonte de ignição deste processo. 
Esta fonte seriam as ações, os eventos e/ou as espacialidades. Estes assim como o espaço sempre presente, mas não necessariamente instantâneos, tem uma duração.

espacialidades, eventos, ações

Sistemas de objetos e sistemas de ações interagem. De um lado, os sistemas de objetos condicionam a forma como se dão as ações e, de outro lado, o sistema de ações leva à criação de objetos novos ou se realiza sobre objetos preexistentes. É assim que o espaço encontra a sua dinâmica e se transforma. (SANTOS, 2002, pg. 63)

Os objetos e as ações - o espaço e a espacialidade se interagem constantemente, o espaço condiciona a ação assim como a ação produz um outro espaço. Uma dinâmica constante. As espacialidades podem acontecer em diversos momentos, podem acontecer simultaneamente compartilhando o mesmo espaço e podem ter períodos (duração) diferentes. As espacialidades são múltiplas o espaço é único. "(...) um evento é um instante do tempo dando-se em um ponto do espaço' (...). (SANTOS, 2002, pg. 144)

\section{PRODUÇÃO SOCIAL DO ESPAÇO}

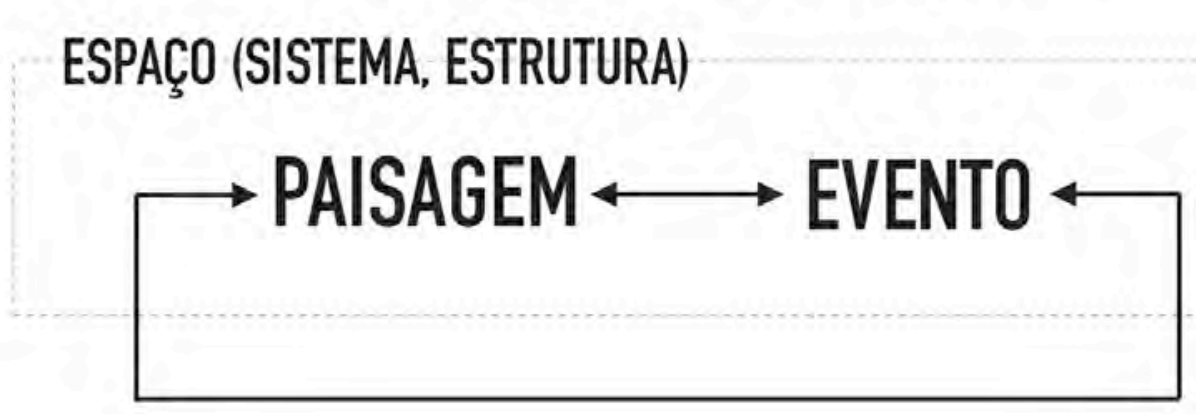

fig.4 diagrama síntese das idéias de Santos e Lefebvre.

Estes conceitos extraídos de Santos e Lefebvre, ilustrado na figura 1 acima, são uma simplificação de estudos que vão muito mais além do que comentamos, vale lembrar que Lefebvre escreve um livro para explicar esta relação (o espaço socialmente produzido), então, vamos simular um pouco esta teoria com alguns exemplos.

Evento:

Aula

Espaço:

O espaço é todo um sistema espacial socialmente produzido que condiciona a aula (a ação). Ou seja, para uma descrição bem rasa do que é esta condição sócio-espacial temos, a estrutura 
institucional, o projeto pedagógico do curso, os planos de ensino, as informações, os livros, as mesas, as cadeiras, os equipamentos de áudio-visual, etc. Repare que espaço não é apenas material, a matéria ou a materialização das ações - fazer uma cadeira - é um passado, logo - paisagem. Mas a mesma carteira, que é uma paisagem da sua própria manufatura é no presente uma condição espacial, uma condição para se produzir um outro espaço e ter como resultado uma paisagem transformada.

Paisagem:

A sala de aula é uma paisagem, paisagem por exemplo da obra que a construiu, uma ação, um evento passado. A posição das carteiras é uma paisagem da ação - limpar - produzida pelos faxineiros num evento que é passado, logo paisagem. Ao fim da aula, as carteiras reviradas, o quadro escrito, o chão sujo é uma paisagem do evento aula que enquanto presente era um espaço socialmente produzido - para Lefebvre, simplesmente, espaço.

Concluído, para o momento, de forma bastante simplificada a questão - espaço. A paisagem, sempre passado, é a materialização do espaço socialmente produzido. A paisagem é a materialização do espaço. $O$ espaço por sua vez é a multiplicação inter-relacionada dos fatores espaço (condicionantes/sistemas) e eventos(ações).

Se a paisagem, é tudo que pode ser visto, logo é imagem. Enquanto imagem, a paisagem também faz parte de um sistema de objetos e automaticamente torna-se espaço. Ou seja a paisagem é espaço. Imagem é espaço; imagem condiciona eventos. 


\section{algumas questões sobre o espaço em Henri Lefèbvre}

Segue aqui uma coleção de trechos do livro a Produção do Espaço (The Production of Space) que elucidam uma pouco mais as questões que já foram colocadas dialogando com o trabalho de Milton Santos, ora confirmando, ora complementando seus estudos.

Lefebvre cita falhas que existem entre as abordagens do espaço:

entre espaço teórico (epistemológico) e espaço prático

entre espaço mental e espaço social

entre espaço dos filósofos e espaço das pessoas que lidam com coisas materiais

Uma sala, um apartamento, uma esquina, um mercado, um espaço público, um shopping, entre outros. São termos do dia a dia usados para distinguir, mas não isolar, espaços particulares, e em geral para descrever o espaço social. Eles correspondem a um uso específico do espaço, e por este motivo uma prática social que eles expressam e constituem. Lefebvre aponta que ao fim de seu trabalho ele pretende construir um sistema espacial.

In either event, the result of our thinking would be the construction of a 'system of space'. (LEFEBVRE, 1974, pg. 16)

A idéia de Lefebvre para a produção do espaço caminha no sentido de se entender o espaço enquanto um produto social. Um produto da prática social, da ação humana apoiado nos ritmos do seu cotidiano ${ }^{17}$.

Uma outra questão importante colocada por Lefebvre é a relação entre corpo e espaço - "bodyspace" (LEFEBVRE, 1974, pg. 170). Primeiramente Lefèbvre nega o espaço absoluto e pressupõe que o espaço é sempre ocupado por corpos.

How does a body 'occupy' space? The metaphorical term 'occupied' is borrowed from an everyday experience as space as already specific, already 'occupied'. The connection between space as 'available' and space as 'occupied, however, has nothing simple or obvious about it. Unfortunately, a metaphor cannot do duty for thought. We know that space is not a pre-existing void, endowed with formal properties alone. To criticize and reject absolute space is simply to refuse a particular representation, that of a container waiting to be filled by content - i.e. matter, or bodies. According to this picture of things (formal) content and (material) container are indifferent to each other and so offer no graspable difference. Any thing may go in any set of places in the container. Any part of the container can receive anything. (LEFEBVRE, 1974, pg. 170)

17 'The history of space does not have to choose between 'processes' and 'structures', change and invariability, events and institutions. Its periodizations, moreover, will differ from generally accepted ones. Naturally, the history of space should not be distanced in any way from the history of time (a history clearly distinct from all philosophical theories of time in general). The departure point for this history of space is not to be found in geographical descriptions of natural space, but rather in the study of natural rhythms, and of modification of those rhythms and their inscription in space by means of human actions, especially work-related actions. It begins, then, with the spatio-temporal rythms of nature as transformed by a social practice." (LEFEBVRE, 1974, pg. 117, grifo nosso) 
Mais adiante, Lefèbvre trabalha a hipótese de que este corpo que ocupa 0 espaço é 0 principal elemento da sua criação.

Can the body, with its capacity for action, and its various energies, be said to create space? Assuredly, but not in the sense that occupation might be said to 'manufacture' spatiality; rather, there is an immediate relationship between the body and its space, between the body's deployment in space and its occupation of space. Before producing effects in the material realm (tools and objects), before producing itself by drawing nourishment from that realm, and before reproducing itself by generating other bodies, each living body is space and has its space: it produces itself in space and it also produces that space. This is a truly remarkable relationship: the body with the energies at its disposal, the living body, creates or produces its own space; conversely, the laws of space, which is to say the laws of discrimination in space, also govern the living body and the deployment of its energies at its disposal, the living body, creates or produces its own space; conversely, the laws of space, which is to say the laws of discrimination in space, also govern the living body and the deployment of its energies. Herman Weyl demonstrates this very clearly in his work on symmetry. In nature, whether organic or inorganic, symmetries (in plane or about an axis) exist wherever there is bilateralism or duality, left and right, 'reflection', or rotation (in space); these symmetries are not properties external bodies, however. Though definable 'purely' mathematical terms - as applications, operations, transformations or functions - they are not imposed upon material bodies, as many philosophers suppose, by prior thought. Bodies deployments of energy - produce space and produce themselves, along with their motions, according to the laws of space. And this remains true, Weyl argues, whether we are concerned with corpuscles or planets, crystals, electromagnetic fields, cell division, shells, or architectural forms, to wich last Weyl attributes great importance. (LEFEBVRE, 1974, pg. 171, grifo nosso)

[...] the form of a seashell is the result neither of a 'design' nor of 'unconscious' thought, nor yet of a 'higher' plan. The poetry of shells - their methaphorical role - has nothing to do with mysteriouscreative force, but corresponds merely to the way in wich energy, under specific conditions (on a specific scale, in a specific material environment, etc.), is deployed; the relationship between nature and space is immediate in the sense that it does not depend on the mediation of an external force, whether natural or divine. The law of space resides within space itself, and cannot be resolved into a deceptively clear inside-versusoutside relationship, which is merely a representation of space. (LEFEBVRE, 1974, pg. 173, grifo nosso)

Aqui Lefebvre conceitua a arquitetura do espaço, ou seja, quais são os componentes que criam 0 espaço. Lefebvre vai na raiz da produção - o corpo - 0 corpo do homem. É notável esta colocação pois vivemos num momento onde o espaço, suas relações e os seus eventos, sua espacialidade estão cada vez mais sendo produzidas por meios digitais - os meios, as espacialidades e os espaços e suas conseqüentes paisagem das redes de informação estão trazendo a materialização do espaço para um momento crítico, apontado por Paul Virilio (1996). O espaço crítico é o espaço onde o tempo das ações e dos eventos é radicalmente alterado acarretando numa ruptura na própria continuidade da materialização do espaço, a materialização do espaço, a produção de paisagens caminha numa velocidade inversa a da espacialidade e da produção do espaço. Nunca se produziu tantos espaços e nunca foi possível se estabelecer e tantas espacialidades em um curto espaço de tempo. Entretanto, a materialização destes espaços e destes eventos é tão veloz que na mesma velocidade que é produzido é também dissolvido. Daí a impermanência e a efemeridade das paisagens contemporâneas. A paisagem de hoje, antes mesmo de ser passado, é inútil tamanha velocidade do estabelecimento e da dissolução dos eventos e dos seus espaços. 
Alguns poucos eventos ainda caminham numa velocidade onde é possível produzir paisagens que tenham uma certa utilidade. O corpo, como ponto de partida para perceber e reconhecer estes espaços é um excelente ponto de partida. O corpo é o espaço e o espaço é produzido a partir do corpo. Logo, a raiz de tudo que se pode pensar sobre o espaço está na sua arquitetura, tendo como arquiteto, o corpo humano.

\section{arquitetura: condição para vida ou ficção urbana?}

A paisagem material não é o suficiente para termos uma cidade, um espaço urbano. Faltam-lhe as dimensões temporais, eventuais, culturais, etc. que dinamizam a vida urbana. Uma construção, por exemplo, como os cenários do Projac ${ }^{18}$ das novelas de Rede Globo são cenários para uma encenação, cenário para uma ficção. A arquitetura na cidade não pode se presentificar como ficção. Logo, sua espacialidade não está apenas na cena, mas numa vida, a vida urbana. Um edifício é muito mais que suporte para uma encenação urbana. Um edifício, uma paisagem urbana é o campo de ação da vida urbana.

dogville

O filme Dogville ${ }^{19}$ (2003) de Lars Von Trier se desenvolve num cenário onde quase toda a paisagem urbana material foi subtraída restando apenas alguns objetos e a vida urbana de uma vila. Este filme sugere que a paisagem é antes de tudo um suporte para a vida urbana. Já o contrário, acreditar que a falta da paisagem pode subtrair a vida é tão insensato quanto a produção arquitetônica que se apóia apenas nas imagens superficiais do edifício.

O ambiente urbano começa no interior das edificações e se estende para fora dos limites da construção. O conjunto de construções é a cidade, a paisagem urbana que é formada por elementos materiais e imateriais. A arquitetura estando na cidade deve fazer parte deste ambiente urbano que é muito mais do que as aparências das superfícies externas da construção. A arquitetura estando na cidade faz parte da vida urbana e se desenvolve numa abordagem oposta à ficção cênica. Dada a ausência da paisagem visual, o filme explora intensamente a paisagem de eventos e a paisagem sonora. Existe um cão na entrada da cidade que sempre late quando um desconhecido aponta na estrada, entretanto, visualmente o cachorro não existe. Existe apenas sua paisagem sonora. Dogville não existe visualmente, assim como seu dog. Entretanto seus eventos são condicionados por esta paisagem visualmente ausente. Este filme trás de forma sutil à nossa percepção uma noção de que a paisagem e os espaços urbanos vão muito além das superfícies materiais visíveis do nosso cotidiano.

${ }^{18}$ Central Globo de Produção, o Projac, em Jacarepaguá (Rio de Janeiro), o maior centro de produção da televisão da América Latina. A área total é de 1.300 .000 metros quadrados, sendo 150 mil de área construída.

19 Uma seleção de frames do filme Dogville podem ser encontradas em anexo no fim da dissertação. 
capítulo 2.

a experiência comum

2.1. hipóteses de percepção, análise e critica do espaço - a paisagem material e a imaterial

2.1.1. análise dos ritmos do cotidiano (Lefebvre - Rhythmanalysis)

2.1.2. paisagem de eventos (Paul Virilio e Tschumi)

2.1.3. paisagem sonora

2.1.4. body violence (Tschumi - Architecture and Disjunction)

2.2. posições do observador/pesquisador; o corpo no urbano - o corpo na paisagem

2.2.1. procedimentos analíticos do corpo na paisagem; da patologia à imersão

2.2.2. a imersão corporal paisagística e seus procedimentos operativos

2.3. práticas: visualização e percepção do espaço comum

2.3.1. considerações gerais

2.3.1.1. a fotografia

2.3.1.2. o panorama

2.3.1.3. o Podcast e o iPod

2.3.2. os experimentos

2.3.2.1. o panorama temporário ${ }^{\mathrm{MM}}$ | panorama.temporario.org

2.3.2.2. paisagens temporárias ${ }^{\mathrm{MM}}$ | temporarylandscape.com

2.3.2.3. 15 minutos $^{\mathrm{MM}}$

2.3.2.4. diárias urbanas ${ }^{\mathrm{MM}}$

2.3.2.5. podscape pM $^{\mathrm{MM}}$

2.3.2.6. MMSoundscapes ${ }^{\mathrm{MM}}$ 
O espaço comum é rebatido aqui enquanto prática, uma prática do arquiteto, do designer e do urbanista em busca de linguagens sensíveis para se experimentar e discutir o espaço comum.

Inicialmente utilizando a fotografia e o vídeo experimentou-se outras formas de registrar as dinâmicas urbanas da metrópole. $\mathrm{O}$ ensaio panoramas temporários ${ }^{\mathrm{MM}}$, por exemplo, aborda questões do tempo, do espaço e da vida cotidiana utilizando uma linguagem não-verbal. Ao longo do seu desenvolvimento percebeu-se seu potencial analítico e crítico. Este experimento que a princípio era um instrumento ilustrativo assume um papel instrumental. Portanto, neste capitulo, experimentos tornam-se procedimentos, ou modos de ação investigativos.

Os experimentos, ainda embrionários, sugerem uma ampliação do repertório técnico operativo de linguagens representacionais aplicados à crítica e à prática do arquiteto, do urbanista e do designer.

Os procedimentos analíticos e críticos propostos aqui são uma série de posturas e ações investigativas desenvolvidas a partir dos experimentos somados às questões teóricas e conceituais colocadas no primeiro capítulo. 
2.1.

hipóteses de percepção, análise e critica do espaço

paisagem: a mentira funcional

2.1. hipóteses de percepção, análise e critica do espaço - a paisagem material e a imaterial

2.1.1. análise dos ritmos do cotidiano (Lefebvre - Rhythmanalysis)

2.1.2. paisagem de eventos (Paul Virilio e Tschumi)

2.1.3. paisagem sonora

2.1.4. body violence (Tschumi - Architecture and Disjunction)

2.2. posições do observador/pesquisador; 0 corpo no urbano - o corpo na paisagem

2.2.1. procedimentos analíticos do corpo na paisagem; da patologia à imersão

2.2.2. a imersão corporal paisagística e seus procedimentos operativos

2.3. práticas: visualização e percepção do espaço comum

2.3.1. considerações gerais

2.3.1.1. a fotografia

2.3.1.2. o panorama

2.3.1.3. o Podcast e o iPod

2.3.2. os experimentos

2.3.2.1. o panorama temporário ${ }^{\mathrm{MM}}$ | panorama.temporario.org

2.3.2.2. paisagens temporárias ${ }^{\mathrm{MM}}$ | temporarylandscape.com

2.3.2.3. 15 minutos $^{\mathrm{MM}}$

2.3.2.4. diárias urbanas ${ }^{\mathrm{MM}}$

2.3.2.5. podscape $^{\mathrm{MM}}$

2.3.2.6. MMSoundscapes ${ }^{\mathrm{MM}}$ 
A paisagem é um conceito operativo que nos permite analisar o espaço. Entendemos a paisagem aqui como um conceito funcional que nos permite estudar o espaço. Milton Santos a considerou como uma espécie de mentira funcional (SANTOS, 2002, p. 23) pois não existe paisagem parada e inerte, se usamos este conceito, o usamos como um recurso analítico (SANTOS, 1997, p.71). No uso deste recurso desenvolvemos alguns conceitos que nos permitem explorar seu potencial analítico. Primeiramente é importante destaca que a paisagem "[...] não é formada apenas de volumes, mas também de cores, movimentos, odores, sons, etc [...]" (SANTOS, 1997, p. 61), "[...] é materialidade formada por objetos materiais e não-materiais [...]" (SANTOS, 1997 p.71).

Ao explorar os recursos analíticos da paisagem, muitos autores acabam agregando conceitos que ampliam seu potencial, exemplos; uma paisagem de eventos (VIRILIO, 2000), paisagem natural e artificial (SANTOS, 1997). Sendo assim, propomos aqui apresentar recursos analíticos de outros autores; ora dialogando, ora embasando os recursos analíticos que foram desenvolvidos ao longo dos experimentos práticos deste trabalho.

\section{paisagem material}

humana e (des)humana

A paisagem material é tátil, visível e tem permanência (SANTOS, 1997), ou seja, por mais que os eventos ao longo do tempo a modifiquem ela sempre estará lá. O fato de ela ter permanência não quer dizer que não seja mutável. Ela é sempre o passado ainda que recente (SANTOS, 1997, p.73), é como se fosse a marca de um evento anterior que se apresenta, se faz presente e está disposto a ser transformado pelo tempo. A paisagem material é o templo de uma igreja, são os edifícios de uma cidade, é o banco de uma praça, uma cadeira numa sala, uma árvore, um campo gramado, uma praia, etc. Tudo que pode ser apreendido pela visão e ser tocado é uma paisagem material. Esta paisagem é a paisagem frequentemente operada pelos paisagistas, fotógrafos, ambientalistas, artistas, defensores do patrimônio histórico, arquitetos, etc. É uma paisagem frequentemente discutida, afinal, é à que nós atribuímos valores financeiros, sentimentais e simbólicos. É uma paisagem que pode ser apropriada, pode-se tomar posse, daí o seu valor agregado.

A paisagem artificial é a paisagem transformada pelo homem, enquanto grosseiramente podemos dizer que paisagem natural é aquela ainda não mudada pelo esforço humano. Se no passado havia a paisagem natural, hoje esta modalidade de paisagem praticamente não existe mais. Se um lugar não é fisicamente tocado pela força do homem, ele, todavia, é objeto de preocupações e de intenções econômicas ou políticas. (SANTOS, 1997 p. 64, grifo nosso)

Como o próprio Santos coloca no seu texto, a paisagem natural é uma modalidade que praticamente não existe mais. Ainda que a paisagem nunca tenha sido alvo de transformações materiais pelo homem, ela já é alvo de posse e de intenções. Então, propomos uma outra interpretação para a paisagem natural e artificial de Santos, ambas interpretadas como paisagem humana. A paisagem humana aqui em questão, assim como a 
natural e a artificial de Santos, podem ser tanto materiais quanto imateriais. No que diz respeito às suas características materiais desenvolvemos: consideraremos a paisagem material como razão consciente, sendo material a partir do momento que o homem toma ciência de sua presença. Esta paisagem material pode ser virgem (SANTOS, 1997, p.70), é o caso dos lugares aonde o homem ainda não chegou e transformou. Ela é natural a partir do momento que o homem toma conhecimento de sua existência - toma posse - abrindo possibilidades para a sua transformação ao longo do tempo. Esta paisagem está prestes a ser uma paisagem transformada pelo homem. A importância desta distinção está justamente ao serem relevadas as características temporais intrínsecas à transformação do espaço por ações humanas. Outro ponto importante é reconhecer que estas transformações são feitas pelo homem enquanto parte de processos naturais, parte da natureza humana. Uma paisagem natural humana. Sendo assim, para efeito deste trabalho, consideraremos que toda paisagem material é natural e humana, ou seja, faz parte da natureza humana. Se a paisagem material não faz parte da natureza humana, não o faz porque o homem não tem ciência da sua existência.

É importante deixar claro que esta distinção, além de ser instrumental, ela é dialética. Os processos de transformação da paisagem natural ao longo do tempo podem se apresentar em escalas de transformações que vão de um ponto de mínima transformação a uma transformação total. Um exemplo de pontos nesta escala seria a paisagem de uma reserva indígena na Amazônia e a paisagem do centro de São Paulo. Podemos dizer que a paisagem tende à uma transformação completa pela ação do homem no espaço.

Desenvolvendo 0 argumento deste texto, concluímos que paisagem natural é uma paisagem humana, ou humanizada com graus de transformação que vão de zero tendendo à sua total transformação. Ou seja, a paisagem artificial de Santos, estamos considerando-a natural apoiados inclusive no próprio argumento do autor que afirma que paisagem natural praticamente não existe mais. A natureza humana é o que está em questão.

Então qual o sentido de se reinterpretar a distinção entre paisagem natural e artificial originalmente colocados por Santos? Porque, dentro da perspectiva de se construir conceitos analíticos espaciais precisamos repensar no que seria uma paisagem artificial?

A paisagem artificial é também uma paisagem transformada pelo homem. É também uma paisagem da natureza humana. Tal como colocado por Santos, praticamente não existe mais uma distinção entre o natural e 0 artificial. Entretanto existe uma modalidade de paisagem humana que se insere no contratempo dos processos naturais de transformação humana da paisagem. É uma paisagem falsa, uma simulação. Daí talvez uma possível reinterpretação deste artificialismo. Artificial do ponto de vista humano.

Esta paisagem que se constrói no contratempo dos processo naturais é uma paisagem sem o homem mesmo que ainda criada pelo homem. É uma paisagem desprovida do homem - (des)humana. Roma, por exemplo, é uma paisagem transformada pelo homem ao longo de milhares de anos. A disposição dos edifícios, 
as fachadas, as relações sociais são paisagens naturalmente construídas pelo homem. Em contrapartida, uma cidade temática de um parque de diversões é uma paisagem artificial, uma paisagem falsa, uma simulação criada pelo homem. As relações do seu cotidiano são baseados num sistema fictício, é um ambiente que existe às custas de uma sistematização espetacular e que para tal funcionamento carece do empenho de recursos humanos (financeiros ou não) que podem ser desfeitos num piscar de olhos. É uma cidade baseada numa construção artificial tal que nos é possível pensar na sua extinção a qualquer momento. Já para uma cidade como Roma, sua extinção seria muito menos factível. Aqui está o verdadeiro sentido de permanência da paisagem colocado por Santos. É uma permanência que está em constante transformação. E esta transformação, natural.

A paisagem material, apesar de ser a maior condicionante do espaço vivido, de ser a mais freqüentada pelos arquitetos, fará parte da análise não com destaque não para suas características materiais físicas, mas atentando para suas possibilidades de condicionar as transformações que o homem realiza no espaço num recorte temporário. A partir da proposição de outras paisagens operativas poderemos tentar buscar uma outra forma de perceber e analisar o espaço.

\section{a paisagem imaterial}

A paisagem imaterial é essencialmente humana e corporal. Ela pressupõe um corpo para percebe-la e/ou (re)produzi-la. É a paisagem da percepção, das sensações e dos sentidos corporais. É uma paisagem efêmera de permanência frágil e temporária.

Se resgatarmos os conceitos operativos de Santos de espaço, paisagem e eventos são os elementos dialéticos que ele usa para entender o espaço. Sabemos que o espaço possui uma dimensão geométrica temporal, logo, o que estamos propondo aqui, seria a ampliação do potencial operativo da paisagem a partir da sua dimensão temporal. A paisagem material supervaloriza o espaço geométrico. A paisagem operativa que estamos propondo parte da hipótese de que se queremos perceber e analisar o espaço precisamos operar com instrumentos que sejam capazes de lidar com todas as suas dimensões, geométricas e temporárias. Daí a importância de introduzirmos os ritmos do cotidiano à analise do espaço. Os ritmos estão no nosso corpo; são percebidos e (re)produzidos pelo corpo. O tempo é dado pelo nosso corpo numa percepção relativa. As ações são conseqüências dos ritmos do nosso cotidiano.

O que temos aqui pode ser entendido como uma paisagem do tempo. Uma paisagem temporária. Logo para nós não nos interessa a dimensão geométrica do espaço, não nos interessa a paisagem material. 0 que está em questão é a dimensão temporal do espaço e uma paisagem que é dada pelo corpo no espaço. Esta paisagem imaterial pode ser entendida também como paisagem dos ritmos (rhythmanalysis), paisagem temporária e/ou paisagem dos eventos. "Cada tipo de paisagem é a reprodução de níveis diferentes de forças 
produtivas, materiais e imateriais, pois o conhecimento também faz parte do rol das forças produtivas." (SANTOS, 1997 p.64) Portanto, faz-se necessário ampliarmos os recursos analíticos espaciais - a paisagem confrontando a paisagem material com a paisagem imaterial. 
2.1.1.

análise dos ritmos do cotidiano

rhythmanalysis

space, time and every day life (LEFEBVRE, 2004)

2.1. hipóteses de percepção, análise e critica do espaço - a paisagem material e a imaterial

2.1.1. análise dos ritmos do cotidiano (Lefebvre - Rhythmanalysis)

2.1.2. paisagem de eventos (Paul Virilio e Tschumi)

2.1.3. paisagem sonora

2.1.4. body violence (Tschumi - Architecture and Disjunction)

2.2. posições do observador/pesquisador; o corpo no urbano - o corpo na paisagem

2.2.1. procedimentos analíticos do corpo na paisagem; da patologia à imersão

2.2.2. a imersão corporal paisagística e seus procedimentos operativos

2.3. práticas: visualização e percepção do espaço comum

2.3.1. considerações gerais

2.3.1.1. a fotografia

2.3.1.2. o panorama

2.3.1.3. o Podcast e o iPod

2.3.2. os experimentos

2.3.2.1. o panorama temporário ${ }^{\mathrm{MM}}$ | panorama.temporario.org

2.3.2.2. paisagens temporárias ${ }^{\mathrm{MM}}$ | temporarylandscape.com

2.3.2.3. 15 minutos $^{\mathrm{MM}}$

2.3.2.4. diárias urbanas ${ }^{\mathrm{MM}}$

2.3.2.5. podscape MM $^{\mathrm{M}}$

2.3.2.6. MMSoundscapes ${ }^{\mathrm{MM}}$ 
Henri Lefebvre em 1992 ao escrever Élements de Rythmanalyse procurava encontrar uma ciência, um novo campo do conhecimento: a análise de ritmos com conseqüências práticas. A idéia era trazer o conceito de ritmo para o campo do conhecimento. Assim, "[...] Lefebvre usa o ritmo como um modo de análise - uma ferramenta para análise mais do que um objeto de análise - para examinar e re-examinar diversos assuntos. [...]" (ELDEN, 2004, p. 12, grifo do autor). Uma metodologia aplicada à critica da vida cotidiana. Para faze-lo, Lefebvre usa o corpo como pivô desta discussão.

In the discussion of the body we can see how Lefebvre recognizes the coexistence of social and biological rhythms, with the body as the point of contact. Our biological rhythms of sleep, hunger and thirst, excretion and so on are more and more conditioned by the social environment and our working lives. We train ourselves, and are trained, to behave in a number of ways. However, Lefebvre believes that the rhythmanalyst does not simply analyse the body as a subject, but uses the body as the first point of analysis, the tool for subsequent investigations. The body serves us as a metronome. This stress on the mode of analysis is what is meant by a rhythmanalysis rather than an analysis of rhythms. (ELDEN, 2004, p. 12, grifo do autor)

In the very last lines of Rythmanalyse, Lefebvre is pleading for listening as the genuine approach to rhythmicity and summarizes that rhythmanalysis is a transdisciplinary field, not a separate discipline. He contradicts the distancing effect of scientific approaches and asks for practical participation. (WINKLER, 2003, p.2)

Lefebvre aponta a análise de ritmos como um campo do conhecimento transdisciplinar; um procedimento cientifíco que requisita uma ação prática do pesquisador. 


\section{a ritmanálise}

O que é ritmo? Todos nós temos noção do que esta palavra significa. Percebemos e sentimos os ritmos, pois fazem parte da nossa vida, mas isso não significa que conhecemos todos os ritmos. (LEFEBVRE, 2004). Revendo Ferrara (1988); percebemos o ritmo, o que não significa que temos um juízo perceptivo do mesmo. Tornamos-nos conscientes dos ritmos quando somos confrontados por alguma irregularidade no mesmo, um descompasso, uma arritmia. (LEFEBVRE, 2004). É pelo desequilíbrio do próprio ritmo e um conseqüente estranhamento que o percebido torna-se conhecido. Outra referência oportuna, usada pelo arquiteto holandês Lars Spuybroek é o da propriocepção. A propriocepção é a habilidade que o corpo possui de executar tarefas dirigidas pelo subconsciente automaticamente. Por exemplo: andar. Se tivéssemos que pensar para executar cada movimento feito por cada músculo da perna ao andar não seríamos capazes de andar e conversar, ou ler um jornal e tomar um café ao mesmo tempo. Esta habilidade do subconsciente nos permite apreender e perceber ritmos sem um juízo lógico. O ritmo é percebido pelo corpo sem necessariamente haver uma consciência desta percepção.

O ritmo difere da repetição mecânica pois é formado por uma seqüência de eventos endógenos. São eventos que fazem parte de um corpo, ou um grupo de corpos, de ações e reações advindas de uma seqüência de eventos.

A repetição mecânica é baseada em um evento exógeno. O relógio por exemplo, modela a vida cotidiana num tempo quantitativo e é baseado numa repetição independente de qualquer seqüência de eventos. 0 ritmo por outro lado tem um tempo diferenciado e uma duração qualificada. Enquanto o mecânico é baseado numa repetição brutal, o ritmo é composto por um conjunto de eventos que podem ser apresentados de forma linear, cíclica, entre outras. (LEFEBVRE, 2004). O ritmo pode ser interrompido ou alterado pela arritmia/disritmia, já a repetição mecânica é contínua e precisa.

A repetição é cansativa, exaustiva e entediante. O recomeço de um ciclo, por outro lado, é a manifestação de um evento e de um advento. Seu começo é sempre um recomeço e parece sempre possuir o frescor de uma descoberta, uma nova invenção. (LEFEBVRE, 2004).

Ao acompanharmos o ciclo de um ipê amarelo até o seu florescimento (o evento) após a secagem e queda das folhas da copa da árvore (o advento), percebemos um ritmo que sempre apresenta com o frescor de uma descoberta, um recomeço. Assim como o nascer e o por do sol que dão ritmos percebidos por nós, mas que não nos impõe uma repetição exaustiva e entediante. Os ritmos são formados por uma série de fatores e condicionantes naturais percebidos e vividos pelo nosso corpo. Logo a análise da vida cotidiana - o cumprimento de tarefas, o transito, os horários de trabalho, o tempo de lazer e outros - nos mostram porque o tempo social é por si só um produto social. O relógio, o tempo mecânico, foi introduzido na nossa cultura aos poucos e este tempo social, ou produto social, assim como todo o produto possui um valor de uso e um valor de troca. Este tempo é por um lado vendido e por outro vivido. (LEFEBVRE, 2004). 
A análise dos ritmos proposta por Lefebvre é uma metodologia de análise do espaço que pressupõe:

- um ponto de vista de um indivíduo específico - o pesquisador por, exemplo.

- e que este indivíduo, é dotado de um corpo sensível apto a perceber as rupturas, arritmias e contratempos do que está sendo analisado.

Trata-se de uma experiência onde o pesquisador usa seu corpo, se insere no espaço de análise e assume um ponto de vista. Trata-se de uma visão aproximada e intuitiva. Uma postura que nega uma visão distante, panorâmica e totalizadora. É o reconhecimento da incapacidade de se conquistar um ponto de vista universal sem que o distanciamento nos leve ao campo das ideologias.

Neste livro Lefebvre coloca em prática o que propõe e faz uma análise do cruzamento da Rua Rambuteau em frente ao Centro Georges Pompidou. Seen From The Window é o nome do texto. Observando detalhadamente todos os eventos do cruzamento por dias e noites ele faz uma análise pessoal de tudo o que observou e percebeu a partir da janela do seu apartamento. Ao finalizar seu relato analítico, conclui:

No camera, no image or series of images can show these rhythms. It requires equally attentive eyes and ears, a head and a memory and a heart. A memory? Yes, in order to grasp this present otherwise than in an instantaneous moment, to restore it in its moments, in the movement of diverse rhythms. The recollection of other moments and of all hours is indispensable, not as a simple point of reference, but in order not to isolate the present and in order to live it in all its diversity, made up of subjects and objects, subjective states and objective figures. Here the old philosophical question (of subject, object and their relations) is found posed in non-speculative terms, close to practice. The observer in the window knows that he takes his time as first reference, but that the first impression displaces itself and includes the most diverse rhythms, on the condition that they remain to scale. The passage from subject to object requires neither a leap over an abyss, nor the crossing of a desert. (LEFEBVRE, 2004, p. 36, grifo do autor) 
2.1.2.

a paisagem de eventos

e a paisagem temporária $M M$

e o cinema panorâmico

2.1. hipóteses de percepção, análise e critica do espaço - a paisagem material e a imaterial

2.1.1. análise dos ritmos do cotidiano (Lefebvre - Rhythmanalysis)

2.1.2. paisagem de eventos (Paul Virilio e Tschumi)

2.1.3. paisagem sonora

2.1.4. body violence (Tschumi - Architecture and Disjunction)

2.2. posições do observador/pesquisador; 0 corpo no urbano - o corpo na paisagem

2.2.1. procedimentos analíticos do corpo na paisagem; da patologia à imersão

2.2.2. a imersão corporal paisagística e seus procedimentos operativos

2.3. práticas: visualização e percepção do espaço comum

2.3.1. considerações gerais

2.3.1.1. a fotografia

2.3.1.2. o panorama

2.3.1.3. o Podcast e o iPod

2.3.2. os experimentos

2.3.2.1. o panorama temporário ${ }^{\mathrm{MM}}$ | panorama.temporario.org

2.3.2.2. paisagens temporáriasMM | temporarylandscape.com

2.3.2.3. 15 minutos $^{\mathrm{MM}}$

2.3.2.4. diárias urbanas ${ }^{\mathrm{MM}}$

2.3.2.5. podscape $\mathrm{MM}^{\mathrm{M}}$

2.3.2.6. MMSoundscapes ${ }^{\mathrm{MM}}$ 


\section{a paisagem de eventos}

Para Paul Virilio (2000) a paisagem não possui um significado fixo e muito menos um ponto de vista privilegiado. A paisagem está para ser apreciada, percebida elou vivida. Seus pontos de vista e seus significados são tantos que é impossível chegar a uma resposta congelada (fixa). Para isso, seria necessário congelar 0 tempo. É neste argumento que ele fundamenta toda uma crítica à análise contemporânea dos fatos históricos. Para ele a "história é uma paisagem de eventos" (VIRILIO, 2000 p.10). Não é possível apreender a história a partir de uma seqüência de eventos única. A história é uma coleção de eventos que se apresentam num plano temporal, sua leitura, apreciação e percepção é individual e sujeita a interpretações diversas. Assim como um observador que ao se colocar diante de uma paisagem percorre em todas as direções com seu olhar em busca de interpretações, assim é a postura sugerida por Virilio diante dos múltiplos fatos históricos. Observar dos grandes aos mínimos eventos dispostos numa paisagem.

Esta postura diante dos fatos históricos também pode ser aplicada aos se observar o espaço cotidiano. Uma postura em que o observado se coloca a observar os eventos. Uma paisagem de eventos.

Como conseqüência das rápidas transformações aplicadas pela modernização global, o tempo, que é uma dimensão espacial, supera a dimensão geométrica do espaço. Aceleração, simultaneidade, colapso são qualidades temporais do espaço contemporâneo. Verificamos estes argumentos ao perceber que cada vez mais estamos medindo distâncias pela dimensão temporal do espaço, ou seja, medir quanto tempo se gasta para chegar num lugar é mais importante do que medir os quilômetros.

[...] Indeed, rarely has a contemporary writer so engaged in an exacerbated analysis of the acceleration of time, to the point where space itself becomes gulfed in time. Space becomes temporal.

For us, as architects, time is spatial because space is what we construct, and time is there to activate these spaces, occasionally to transform them by challenging the perception of their boundaries. Time is what allow us to measure space. [...] society has become entirely a function of time, and that duration is really a conjunction of simultaneities. [...]

[...] Paul Virilio's thesis may be simply that time has finally overcome space as our main mode of perception. (TSCHUMI, 2000, p.8, grifo nosso)

Bernard Tschumi insiste que o arquiteto que constrói espaços para uma sociedade onde o tempo superou a geometria deve estar atento aos eventos. O evento, a dimensão temporal do espaço, ativa os espaços e estabelece seus verdadeiros limites. Tschumi afirma que "(...) não existe espaço sem eventos, nem arquitetura sem programas. (...) a arquitetura - sua importância social e criação formal - não pode ser dissociada dos eventos que acontecem em seus espaços." (TSCHUMI, 1996, p. 139). 


\section{a paisagem temporária $\mathrm{MM}$}

A paisagem temporáriaMM pode ser entendida sob dois aspectos:

- o primeiro diz respeito a uma paisagem que se apresenta por um determinado tempo e depois se desfaz;

- o segundo diz respeito a uma paisagem que é percebida e registrada por um determinado tempo.

Logo temos uma interpretação que é apresentativa e uma outra (re)presentativa. Uma diz respeito ao presente, ao momento vivido e percebido, outra, ao passado de um momento vivido e percebido, capturado e eternizado por um instrumento que o permita se (re)fazer presente - (re)presentificar a qualquer momento.

Os eventos são uma paisagem temporária naturalmente, acontecem por um determinado tempo num espaço. Os eventos dizem respeito ao presente. Quando capturados, estes são temporários, mas temporários não mais no sentido de sua natureza apresentativa, sua duração, mas também somados à uma duração do próprio registro.

O cinema é uma paisagem temporária? Não. Apesar de registrar um evento e ser um instrumento capaz de (re)presentificá-lo a qualquer momento o cinema é um recorte temporário, e não uma paisagem. Assim como coloca Paul Virilio, a paisagem deve permitir uma relação espaço/tempo e pressupõe uma sobreposição de tempos, um tempo múltiplo. Pressupões também a possibilidade do observador se colocar diante dos eventos e direcionar seu olhar para a direção que bem entender. O cinema é de tempo único, única visada e abre poucas possibilidades para se expandir novos horizontes visuais. Mas isso não significa que 0 cinema seja incapaz de buscar uma (re)presentação da paisagem. O filme Play Time ${ }^{20}$ (1967) de Jacques Tati é

\section{Play Time}

Grand prix de l'académie du cinéma, Paris, 1968. Médaille d'argent au festival de Moscou, 1969. Prix du festival du film de Vienne, 1969. Oscar du cinéma suédois, Stockholm, 1969.

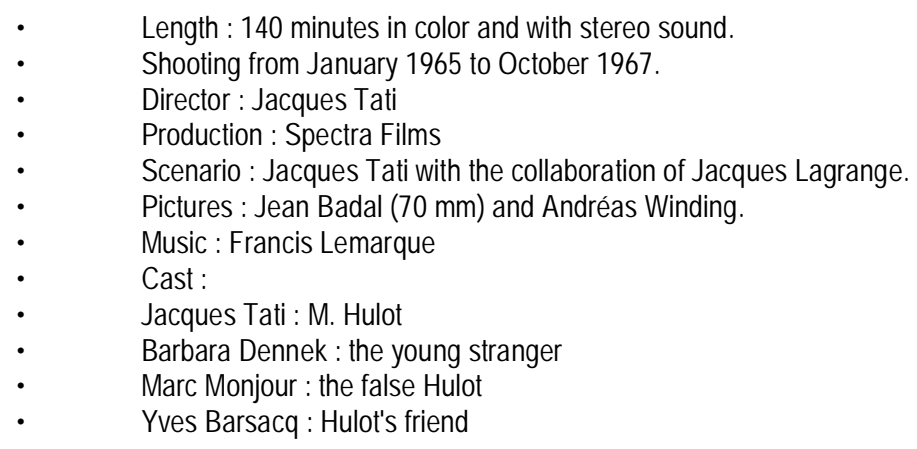

Playtime is the epic of the modern world. Everything has the same size as the highways and the buildings. Tati gives up the 35 $\mathrm{mm}$ in favor of the $70 \mathrm{~mm}$. When you have to film a frontage, the $35 \mathrm{~mm}$ shows only few windows, but the $70 \mathrm{~mm}$ shows the whole building. Playtime is firstly a set: the hall of an airport, the interior and surroundings of some modern buildings, and the interior of a restaurant.

Tati thought that he could film his movie on location, but the cost and the material difficulties forced him to avoid this part of his project. 
um exemplo singular nesta questão. $O$ fato do cinema não ter sido frequentemente tratado como paisagem não significa que esta hipótese não exista.

Tati e o cenógrafo e arquiteto Eugène Roman construíram nos arredores de paris, perto de Vicennes uma cidade cinematográfica para locar uma ficção que retratasse o cotidiano de uma cidade modernista.

Play Time foi filmado em $70 \mathrm{~mm}$ de modo que pudesse criar espaço suficiente na tela para permitir que o olhar do espectador vagueie pelo cenário. Esta película, de proporções panorâmicas, adicionado aos planos gerais do diretor abre uma vasta janela com diversos eventos simultâneos em diferentes pontos do espaço. Deste modo, o filme permite que o olhar do espectador percorra todo o cenário como na vida real. 0 plano geral também lhe permite perder Hulot (o personagem principal do filme) que frequentemente deixar de ser o centro da atenção transferindo-a para figurantes não profissionais.

Aqui temos uma experiência de Tati, feita no cinema que busca de alguma forma registrar e (re)presentar o espaço agregando a este registro suas dimensões temporais. 0 evento torna-se o centro do registro e o modo de (re)presentação, tendendo a panorama, busca uma paisagem, uma paisagem temporáriaMM

Assim, temos a paisagem temporária ${ }^{\mathrm{MM}}$ enquanto um instrumento de (re)presentação da paisagem dos eventos de Virilio. Por ser temporária é capaz de conter múltiplas camadas de tempo e assim como o espaço permitir múltiplas leituras e percepções.

\section{o cinema panorâmico}

Imagine-se inserido num edifício como o Panorama de Robert Barker e que ao invés de um grande painel pintado tivéssemos projeções em toda superfície circular do edifício. Este seria o cinema panorâmico, uma tela com projeções em 360 graus. Existem alguns experimentos de cinema panorâmico. Na França, por exemplo, existem três. Arromanches ${ }^{21}$ é um destes experimentos.

Then he began to build Tativille, the background of his movie, on the East side of Paris near Vincennes. The construction began in July 1964. 2 electricity plants were also built. The construction was finished in January 1965

A lot of cars enable Tati to simulate heavy traffic.

On the scene, the technicians and the actors discover step by step what Tati wants from them. He explains that the actors perform better when they do not know all the details of the scenario.Tati's requirements (shooting again and again the same sequences) and the accumulation of delays make Tati get into very important financial difficulties.Playtime was to have a very bad career: Hulot is not visible enough, and the number of cinema rooms with $70 \mathrm{~mm}$ projectors is too small. Tati must accept his failure.

fonte: http://www.delboy.com/ptus.htm (verificado a disponibilidade em 19/12/2005)

${ }^{21}$ Arromanches, a travel in History...

The SAEM Arromanches 360, created upon the initiative of Lower Normandy Regional Council for the Fiftieth Anniversary of the Landings, presents for you an exceptional film on 9 screens in a circular cinema: The Price of Freedom. 
Ao inserir o espectador no centro de um evento numa (re)presentação espacial temporária, tanto no registro quanto em sua reprodução, o cinema panorâmico desenvolve o que Tati havia iniciado. Este cinema possui um grande potencial para se discutir, experimentar e analisar as dimensões temporais do espaço sem negar sua dimensão geométrica. Aqui temos um dos instrumentos de visualização mais instigantes para ser desenvolvido e explorado nos próximos anos. 0 cinema panorâmico poderá, assim como a fotografia, o précinema, o cinema e o vídeo, trazer outras contribuições para a ciência permitindo ao corpo experimentar 0 espaço de outras formas.

The price of freedom, an Arromanches 360 exclusive.

An exclusive procedure is employed to obtain the 360-degree projection: the Circorama, conceived by Patrick Besenval and the Futuroscope productions.

The 360 degree theater at Futuroscope is the first in France. Today there are three similar cinemas: Futuroscope, Euro-Disney and Arromanches 360 .

Arromanches 360 , the film.

At Arromanches 360 you will be at the heart of the event. This film The Price of Freedom, presented on 9 screens in a circular cinema and projected by an exclusive process, mixes unreleased footage from archives of war correspondents with present day pictures shot on location in now peaceful settings.

With its 360 degrees projection, you will be plunged at the Heart of the Action, among the fighters on D-Day, and will thus feel all the intensity of this great moment that was the Landings of the Allied forces in Normandy.To see, to understand, to meditate... The special trip in history, this return to the past on the beaches of 6 June 1944, will be for all an intensitive emotion and an unforgettable experience.

Unique in the region, Arromanches 360 is the third cicular cinema in France. The filming of the current images of Normandy were achieved due to an exclusive procedure made popular by Futuroscope.The system of 9 cameras mounted on a tank, a helicopter, a ship... will place you at the heart of the countryside and the action. You will drift among the pontoons at Arromanches, overfly the Pointe du Hoc, penetrate to the heart of the bunkers and come ashore at Omaha Beach.

The price of Freedom is projected on 9 screens in a circular theater. A projector and a fim canister with 585 meters of film serves each screen. 18 minutes of projection in 360 degrees corresponds to 2 long feature films. The Price of Freedom consists of 65,000 images of archives filmed during those events in 1944. A major effort was realized in order to adapt them to the 360 degree technique. Shaking because they were filmed in very difficult conditions, they were all rephotographed in order to be stabilized and cut into two or three screens. In classic films the projection speed is 24 images per second; for a perfect synchronization between the images and the sound track we have 25 images per second.

At arromanches 360 , the projection is entirely automated by a programmable automation which controls also the opening of the doors as well as the ambient lighting.

During the projection the sound surrounds you. The Price of Freedom does not include any commentary, a sound track was created for the film. The nine speakers are placed behind each screen. The images of archives are accompagnied by the noise retained in the memory of the veterans of the period and the current images are accompanied by music. 
2.1.3.

a paisagem sonora ${ }^{\mathrm{MM}}$ (soundscape ${ }^{22}$ )

2.1. hipóteses de percepção, análise e critica do espaço - a paisagem material e a imaterial

2.1.1. análise dos ritmos do cotidiano (Lefebvre - Rhythmanalysis)

2.1.2. paisagem de eventos (Paul Virilio e Tschumi)

2.1.3. paisagem sonora

2.1.4. body violence (Tschumi - Architecture and Disjunction)

2.2. posições do observador/pesquisador; 0 corpo no urbano - o corpo na paisagem

2.2.1. procedimentos analíticos do corpo na paisagem; da patologia à imersão

2.2.2. a imersão corporal paisagística e seus procedimentos operativos

2.3. práticas: visualização e percepção do espaço comum

2.3.1. considerações gerais

2.3.1.1. a fotografia

2.3.1.2. o panorama

2.3.1.3. o Podcast e o iPod

2.3.2. os experimentos
2.3.2.1. o panorama temporário ${ }^{\mathrm{MM}} \mid$ panorama.temporario.org
2.3.2.2. paisagens temporárias ${ }^{\mathrm{MM}} \mid$ temporarylandscape.com
2.3.2.3. 15 minutos ${ }^{\mathrm{MM}}$
2.3.2.4. diárias urbanas $\mathrm{MM}$
2.3.2.5. podscape $\mathrm{MM}$
2.3.2.6. MMSoundscapes ${ }^{\mathrm{MM}}$

${ }^{22}$ Soundscape is an artificial word, playing on the acoustic similarity of sound and land. Composer and sound theorist Murray Schafer created the word in the late 1960s.

Simultaneously and independently, Michael Southworth at MIT also used the term. The World Soundscape Project at Simon Fraser University made the word widely known and linked with a specific approach subsumed under the then new and then- fashionable notion of ecology. (WINLKEY, 2003, p.15) 
O som é essencialmente dotado de dimensões espaciais geométricas e temporais. Sendo assim, o som é um meio que possui um grande potencial para se pesquisar o cotidiano urbano.

A partir de sua condição espacial, perceptível e sensível ao homem, o som pode ser entendido como paisagem a partir de uma noção ambiental. $O$ estudo de ambientes sonoros remontam a experimentos científicos a partir do século XIX, entretanto seus principais precursores foram o psicólogo alemão Willy Hellpach e o geógrafo Johan Gabriel Grano já nos anos 30 do século XX (Winkler, 2003). Estes experimentos embrionários foram resgatados e introduzidos com o termo soundscape por R. Murray Schafer nos anos 60 na Simon Fraser University in British Columbia. Outros experimentos com soundscapes foram desenvolvidos no fim dos anos 70 por Jean- François Augoyard na Universidade de Grenoble e pelo departamento de Planejamento e Arquitetura do MIT (Massachusetts Institute for Technology) entre outras instituições de ensino e pesquisa conforme nos conta Justin Winkler23 (2003):

The so far the most focused activities that led to systematic scientific approaches go back to the 1960s and 70s. When teaching at the 1965 newly founded Simon Fraser University in British Columbia composer and musicologist R. Murray Schafer started the "World Soundscape Project" WSP (1970-1975). In 1979 was created the "Centre de recherche sur l'espace sonore" CRESSON in Grenoble by philosopher and urbanist Jean- François Augoyard.

Activities with less institutional continuity are recorded in 1968-69 in the planning and architecture department at the Massachusetts Institute for Technology MIT (Michael Southworth), 1984 in "Espaces Nouveaux" (Louis Dandrel), since 1987 at

the "Laboratoire d'acoustique et musique urbaines" LAMU (Pierre Mariétan) in Paris, and since 1990 at the planning department of the Universität/Gesamthochschule Kassel (Detlev Ipsen). In the 1990s research is done at Folk Studies Department of University of Tampere (Helmi Järviluoma), Geography Department of University of Basel (Justin Winkler), and in the interdisciplinary research program Mensch-Umwelt- Beziehungen of University of Oldenburg (August Schick, Wolfgang Nitsch et al.).

Parallel with these attempts to create systematic approaches a number of punctual work in the zone between science, arts and broadcast can be tracked. Despite efforts to create sonological curricula, musicological and musical institutions are practically absent. A great

\footnotetext{
${ }^{23} \mathrm{http}: / / w w w . h u m g e o . u n i b a s . c h / h o m e p a g e s /$ winkler.htm
}

PD Dr. Justin Winkler

Department of Geosciences Geography / Urban and Regional Studies University of Basel Klingelbergstrasse

Main fields of activity

soundscape studies

- landscape aesthetics \& landscape history, aesthetics \& history of environment, plurisensory perception

- cultural geography, rural and urban geography

- research methodologies and history

- Klanglandschaftsforschung

- Landschaftsästhetik und Landschaftsgeschichte, Umweltästhetik, plurisensorielle Perzeption

- Forschungsmethodik und -geschichte

- études du paysage sonore

- esthétique du paysage et histoire du paysage, esthétique de l'environnement, perception

- plurisensorielle

- méthodes et histoire de recherche 
number of graduate, master and doctoral theses have been written in various disciplines which did not find their way out to the public sphere.

(WINKLER, 2003, p.29 e 30, grifo nosso)

O que nos motiva a incluir estes experimentos neste trabalho são seus procedimentos e posturas metodológicas de pesquisa transdisciplinares. Este procedimento implica numa relação de proximidade entre 0 sujeito e o objeto, o pesquisador e seus assuntos de interesse tal como nos coloca Winkler:

[...] the idea of a radical transdisciplinarity is basically known to all soundscape researchers; it implies that there are no fundamental divisions between subjective and objective, the researcher and his/her subject of interest. [...] (WINKLER, 2003, p.3)

Trata-se de uma postura comparada à paisagem de eventos onde a forma que 0 observador se coloca diante dos eventos da paisagem é a questão. 0 pesquisador e o objeto ou o pesquisador e a paisagem se misturam. É o pesquisador inserido na paisagem.

Outro postura que nos interessa é a ênfase temporal, ou seja, a possibilidade de se apreender as características temporais do espaço. Como o espaço se modifica ao longo de algumas horas, dias e semanas? Para isso, a análise rítmica do espaço torna-se uma referência para Winkley. Os ciclos de eventos, segundo Lefebvre em rhythmanalisys, pode direcionar os métodos de captura e análise das paisagens sonoras.

Approaching soundscape from two opposite directions means that any "systematic" documentation has to cope from the start with enormous complexity and has to spend considerable time in order to achieve an adequate representation of sequences and cycles which constitute it. This is also why recording a "soundscape", and not merely producing "acoustic postcards", is so rarely achieved, and why archiving single sound events is far from documenting soundscapes. (WINKLEY, 2003, p.29 e 30, grifo nosso) 


\title{
2.1.4.
}

body violence (Tschumi - Architecture and Disjuction))

evento, corpo e espaço

2.1. hipóteses de percepção, análise e critica do espaço - a paisagem material e a imaterial

2.1.1. análise dos ritmos do cotidiano (Lefebvre - Rhythmanalysis)

2.1.2. paisagem de eventos (Paul Virilio e Tschumi)

2.1.3. paisagem sonora

2.1.4. body violence (Tschumi - Architecture and Disjunction)

2.2. posições do observador/pesquisador; o corpo no urbano - o corpo na paisagem

2.2.1. procedimentos analíticos do corpo na paisagem; da patologia à imersão

2.2.2. a imersão corporal paisagística e seus procedimentos operativos

2.3. práticas: visualização e percepção do espaço comum

2.3.1. considerações gerais

2.3.1.1. a fotografia

2.3.1.2. o panorama

2.3.1.3. o Podcast e o iPod

2.3.2. os experimentos

\author{
2.3.2.1. o panorama temporário ${ }^{\mathrm{MM}} \mid$ panorama.temporario.org \\ 2.3.2.2. paisagens temporárias ${ }^{\mathrm{MM}}$ | temporarylandscape.com \\ 2.3.2.3. 15 minutos $^{\mathrm{MM}}$ \\ 2.3.2.4. diárias urbanas ${ }^{\mathrm{MM}}$ \\ 2.3.2.5. podscape ${ }^{\mathrm{MM}}$ \\ 2.3.2.6. MMSoundscapes ${ }^{\mathrm{MM}}$
}


No livro "Architecture and Disjunction", Bernard Tchumi assume uma postura crítica teórica e prática frente ao cenário da arquitetura dos anos 80 e 90. Sua inquietação concentrava-se principalmente no distanciamento da prática sócio-espacial recorrente na produção e crítica da arquitetura. Ou seja, a exacerbada importância que o ensino de arquitetura, a crítica e os arquitetos davam aos estilos acabavam por reduzir a arquitetura à um "sistema de superfícies significantes"24 (TSCHUMI, 1996, pg. 140). Sendo assim, Tschumi revogava, tanto à teoria quanto a prática da arquitetura a questão programática. 0 programa era tratado como evento no espaço. Assim como na paisagem de eventos de Paul Virilio, os eventos para Tschumi tem uma atenção especial, pois estes são os pivôs do espaço. E segundo o próprio Tschumi;

[...] There is no architecture without action, no architecture without events, no architecture without program. [...] (TSCHUMI, 1996, pg. 121, grifo nosso) [...] architecture -its social relevance and formal invention - cannot be dissociated from the events that "happen" in it. [...] (TSCHUMI, 1996, pg. 139, grifo nosso)

Nesta mesma publicação, Tschumi relata sua experiência docente na Architectural Association (AA) em Londres no programa Teoria, Linguagem e Atitudes. A partir das teorias criticas de Baudrillard, Lefèbvre, Adorno, Lukàcs e Benjamin sobre a cidade, Tschumi (1996, pg. 142) explora a sensibilidade artística da fotografia, da arte conceitual e da performance acreditando que a oposição entre linguagem verbal e visual são complementares.

[...] Student's projects explored that overlapping sensibility, often in a manner sufficiently obscure to generate initial hostility through the school. Of course the codes used in student's work differed sharply from those seen in schools and architectural offices at the time. At the end-of-year exhibition texts, tapes, films, manifestos, rows of story-boards, and photographs of ghostlike figures, each with their own specific conventions, instruded in space arranged according to codes disparate from those of the profession. [...] (TSCHUMI, 1996, pg. 143, grifo nosso)

Para Tschumi, não há arquitetura sem ação, eventos, programas "consequentemente, não há arquitetura sem violência" (TSCHUMI, 1996, pg. 121). A lógica dos objetos e a lógica do homem são independentes na relação com o mundo, inevitavelmente existe um confronto intenso entre homens e objetos. A relação entre o edifício e seus usuários é uma violência para Tschumi que argumenta que qualquer uso dos

24 [...] For throughout the 1970s there was an exacerbation of stylistic concerns at the expense of programmatic ones and a reduction of architecture as a form of knowledge to architecture as knowledge of form. From modernism to postmodernism, the history of architecture was surreptitiously turned into a history of styles. This perverted form of history borrowed from semiotics the ability to "read" layers of interpretation but reduced architecture to a system of surface signs at the expense of the reciprocal, indifferent, or even conflictive relationship of space and events." [...] (TSCHUMI, 1996, pg. 140)

[...] However, it should be stressed that it is no accident that this emphasis on stylistic issues corresponded to a double and wider phenomenon: on the one hand, the increasing role of the developer in planning large buildings, encouraging many architects to become mere decorators, and on the other, the tendency of many architectural critics to concentrate on surface readings, signs, metaphors, and other modes of presentation, often to the exclusion of spatial or programmatic concerns. These are two faces of a single coin, typical of an increasing desertion by the architectural profession of its responsibilities vis-à-vis the events and activities that take place in the spaces it designs." [...] (TSCHUMI, 1996, pg. 140 - 141) 
espaços significa a "intrusão do corpo humano" (TSCHUMI, 1996, pg. 121). Com estes argumentos ele introduz o termo body violence ampliando um pouco mais a noção de espaço arquitetônico. Primeiramente ele introduz a necessidade de se entender a arquitetura e seus espaços a partir das ações e seus eventos, entretanto aqui ele ressalta que reduzir os espaços arquitetônicos a eventos é tão simplista quanto reduzir a arquitetura a suas fachadas. A intrusão é inerente à arquitetura. Esta intrusão, ou violação é vista por Tschumi por dois aspectos: tanto o corpo pode violar os espaços quanto os espaços podem violar o corpo:

[...] First, there is the violence that all individuals inflict on spaces by their very presence, by their intrusion into the controlled order of architecture. Entering a buiding may be delicate act, but it violates the balance of a precisely ordered geometry (do architectural photographs ever include runners, fighters, lovers?). Bodies carve all sorts of new and unexpected spaces, through fluid or erratic motions. Architecture, then, is only an organism engaged in constant intercourse with users, whose bodies rush against the carefully estabilished rules of architectural thought. No wonder the human body has always been suspect in architecture: it has always set limits to the most extreme architectural ambitions. The body disturbs the purity of architectural order. It is equivalent to a dangerous prohibition.

Violence is not present. Just as riots, brawls, insurrections, and revolutions are of limited duration, so is the violence a body commits against space. Yet it is always implicit. Each door implies the movement of someone crossing the frame. Each corridor implies the progression of movement that blocks it. Each architectural space implies (and desires) the intruding presence that will inhabit it. [...]

[...] But if bodies violates the purity of architectural spaces, one might rightly wonder about the reverse: the violence inflicted by narrow corridors on large crowds, the symbolic or physical violence of buildings on users. A word of warning: I do not wish to resurrect recent behaviorist architectural approaches. Instead, I wish simply to underline the mere existence of a physical presence and the fact that it begins quite innocently, in an imaginary sort of way. [...] Violence exercised by and through space is spatial torture. [...]

(TSCHUMI, 1996, pg. 123 - 124, grifo nosso)

O trabalho de Tschumi apresentado aqui é uma referência importante para este trabalho a partir dos seguintes argumentos;

O primeiro, seria o entendimento da arquitetura enquanto disciplina sócio-espacial que precisa ser prioritariamente analisada e criticada a partir de suas dimensões espaciais temporais - 0 evento - e nunca apenas de suas dimensões geométricas ou de suas imagens e significados impressos nas suas superfícies materiais.

O segundo, é a ampliação do primeiro. O evento em si não é nada se não considerarmos como pivô de análise o corpo humano que é o responsável não somente pela geração dos eventos, mas também por, constantemente, entrar em conflito com as dimensões geométricas do espaço. Resgatando um pouco mais as discussões de Lefèbvre, aqui podemos estabelecer um diálogo com o texto Spatial Architetectonics do livro The Production of Space (1974). Neste texto, Lefèbvre diz que o corpo é espaço ao mesmo tempo que produz seu próprio espaço. Para Tschumi o corpo tem uma função essencial na análise, na percepção e na geração dos espaços arquitetônicos. É exatamente nessa relação referenciada corpo-espaço que os experimentos apresentados nesta dissertação se apóiam assim como enfatizam a dimensão temporal do espaço ao registrar eventos do cotidiano urbano. 
2.2.

posições do observador/pesquisador; o corpo no urbano - o corpo na paisagem

2.1. hipóteses de percepção, análise e critica do espaço - a paisagem material e a imaterial

2.1.1. análise dos ritmos do cotidiano (Lefebvre - Rhythmanalysis)

2.1.2. paisagem de eventos (Paul Virilio e Tschumi)

2.1.3. paisagem sonora

2.1.4. body violence (Tschumi - Architecture and Disjunction)

2.2. posições do observador/pesquisador; o corpo no urbano - o corpo na paisagem

2.2.1. procedimentos analíticos do corpo na paisagem; da patologia à imersão

2.2.2. a imersão corporal paisagística e seus procedimentos operativos

2.3. práticas: visualização e percepção do espaço comum

2.3.1. consideraç̃os gerais
2.3.1.1. a fotografia
2.3.1.2. o panorama
2.3.1.3. o Podcast e o iPod

2.3.2. os experimentos

2.3.2.1. panoramas temporários ${ }^{\mathrm{MM}}$

2.3.2.2. paisagens temporárias ${ }^{\mathrm{MM}}$ | temporarylandscape.com

2.3.2.3. 15 minutos $^{\mathrm{MM}}$

2.3.2.4. diárias urbanas ${ }^{\mathrm{MM}}$

2.3.2.5. podscape ${ }^{\mathrm{MM}}$

2.3.2.6. MMSoundscapes ${ }^{\mathrm{MM}}$ 
2.2.1.

procedimentos analíticos do corpo na paisagem; da patologia à imersão.

2.1. hipóteses de percepção, análise e critica do espaço - a paisagem material e a imaterial

2.1.1. análise dos ritmos do cotidiano (Lefebvre - Rhythmanalysis)

2.1.2. paisagem de eventos (Paul Virilio e Tschumi)

2.1.3. paisagem sonora

2.1.4. body violence (Tschumi - Architecture and Disjunction)

2.2. posições do observador/pesquisador; o corpo no urbano - o corpo na paisagem

2.2.1. procedimentos analíticos do corpo na paisagem; da patologia à imersão

2.2.2. a imersão corporal paisagística e seus procedimentos operativos

2.3. práticas: visualização e percepção do espaço comum

2.3.1. considerações gerais

2.3.1.1. a fotografia

2.3.1.2. o panorama

2.3.1.3. o Podcast e o iPod

2.3.2. os experimentos

2.3.2.1. o panorama temporário ${ }^{\mathrm{MM}} \mid$ panorama.temporario.org

2.3.2.2. paisagens temporárias ${ }^{\mathrm{MM}}$ | temporarylandscape.com

2.3.2.3. 15 minutos $^{\mathrm{MM}}$

2.3.2.4. diárias urbanas ${ }^{\mathrm{MM}}$

2.3.2.5. podscape ${ }^{\mathrm{MM}}$

2.3.2.6. MMSoundscapes ${ }^{\mathrm{MM}}$ 
Os procedimentos recorrentes para análise do espaço urbano praticado pelos arquitetos e pelos designers tem sido quase sempre a partir da patologia de imagens. Trata-se de um procedimento análogo à patologia ${ }^{25}$, um procedimento da medicina. A partir de paisagens congeladas pelo instante fotográfico são desenvolvidos diagnósticos que nos permitam discutir e associar as linguagens desenvolvidas no urbano através de suas imagens. Neste procedimento são detectados falhas e erros de construção contrapostos a uma imagem perfeita - uma imagem ideal para a cidade (se é que existe tal imagem). A partir deste diagnóstico podemos dissertar sobre uma cidade doente que precisa ser curada, (re)construída segundo os modelos idealizados pelos arquitetos e designers. Entretanto devemos nos perguntar qual o limite desta postura? Até quando nós arquitetos podemos estabelecer os modelos ideais, a imagem ideal para a cidade e continuar praticando análises patológicas do espaço urbano? Trata-se de uma questão de postura do arquiteto e do designer. Um arquiteto que se posiciona como um médico que a partir de imagens tais como radiografias, dados coletados, exames, sintomas, relatos e observações elabora um diagnóstico e propõe uma ação que visa a cura. O médico não consegue elaborar uma análise experimentando as percepções e sensações do paciente, salvo numa situação de auto-análise. A análise patológica é sempre uma análise distanciada, uma análise de um corpo OUTRO que não o EU.

Para efeito deste trabalho não cabe discutir este procedimento em si e seus desdobramentos teóricos e conceituais. O que está em questão aqui é a possibilidade de se fazer uma análise imersiva, ou seja, a partir de uma experiência do corpo fazer a análise do urbano. É um procedimento em que o corpo está imerso no objeto de estudo, é o corpo inserido na paisagem.

Para efeito prático, nesta postura o pesquisador deve ser destituído de impessoalidades e se posicionar enquanto sujeito. 0 sujeito que é 0 arquiteto, o designer, o planejador, o pesquisador, etc, e que enquanto sujeito, possui um corpo que está inserido no espaço de análise. Assumindo a postura proposta, podemos desenvolver adotar alguns procedimentos operativos.

Os procedimentos que estamos discutindo aqui foram desenvolvidos, aplicados e/ou adotados nos experimentos que serão apresentados e comentados nesta dissertação. São procedimentos e/ou posturas de referência do pesquisador no espaço pesquisado - o espaço comum. Seguindo o trabalho, estaremos discutindo a imersão corporal paisagística e seus procedimentos operativos.

$$
{ }^{25} \text { patologia }
$$

Acepções

substantivo feminino

1 Rubrica: medicina.

especialidade médica que estuda as doenças e as alterações que estas provocam no organismo

2 Rubrica: medicina.

qualquer desvio anatômico e/ou fisiológico, em relação à normalidade, que constitua uma doença ou caracterize determinada doença

3 Derivação: por extensão de sentido.

desvio em relação ao que é próprio ou adequado ou em relação ao que é considerado como o estado normal de uma coisa inanimada ou imaterial 
2.2.2.

a imersão corporal paisagística e seus procedimentos operativos

2.1. hipóteses de percepção, análise e critica do espaço - a paisagem material e a imaterial

2.1.1. análise dos ritmos do cotidiano (Lefebvre - Rhythmanalysis)

2.1.2. paisagem de eventos (Paul Virilio e Tschumi)

2.1.3. paisagem sonora

2.1.4. body violence (Tschumi - Architecture and Disjunction)

2.2. posições do observador/pesquisador; o corpo no urbano - o corpo na paisagem

2.2.1. procedimentos analíticos do corpo na paisagem; da patologia à imersão

2.2.2. a imersão corporal paisagística e seus procedimentos operativos

2.3. práticas: visualização e percepção do espaço comum

2.3.1. considerações gerais

2.3.1.1. a fotografia

2.3.1.2. o panorama

2.3.1.3. o Podcast e o iPod

2.3.2. os experimentos

2.3.2.1. o panorama temporário ${ }^{\mathrm{MM}} \mid$ panorama.temporario.org

2.3.2.2. paisagens temporárias ${ }^{\mathrm{MM}} \mid$ temporarylandscape.com

2.3.2.3. 15 minutos $^{\mathrm{MM}}$

2.3.2.4. diárias urbanas ${ }^{\mathrm{MM}}$

2.3.2.5. podscape $^{\mathrm{MM}}$

2.3.2.6. MMSoundscapes ${ }^{\mathrm{MM}}$ 
O pesquisador é o arquiteto e urbanista que participa dos eventos de um espaço. Este espaço é uma situação urbana ou um estudo de caso. Logo o arquiteto pesquisador está inserindo na paisagem pesquisada, ou seja o corpo do pesquisador faz parte da paisagem pesquisada. O que se propõe é uma imersão corporal paisagística. A pesquisa presencial torna-se um procedimento fundamental neste trabalho. Sendo assim, qualquer registro coletado - fotos, vídeos, sons, entre outros - não são ilustrações ou exemplos de uma pesquisa previamente elaborada, de fato é a própria pesquisa que se constrói simultaneamente com os registros. Este pesquisador pode a princípio assumir duas posturas distintas;

- o pesquisador presencia os eventos sem interferir, sem participar ativamente destes eventos

- o pesquisador presencia e participa ativamente dos eventos

A primeira hipótese, em que o pesquisador participa sem interferir ele assume um papel de testemunha. Talvez alguns podem entender esta postura como a de um observador, um voyeur, e consequentemente entender este pesquisador como fora da paisagem, um olhar distanciado. Entretanto este afastamento não existe, ele seria possível apenas se o pesquisador não estivesse lá com a sua câmera ou qualquer outro instrumento de registro. Basta, por exemplo, ver as fotos, algumas pessoas olham para a câmera, outras se aproximam, algumas fogem, escondem. Ainda que o registro não tenha competência para tanto, a memória do pesquisador associa estes registros às sensações térmicas, cheiros, ruídos, sons, diálogos entre outros simplesmente por estar inserido naquela paisagem. Sem falar que o próprio manusear, direcionar e operar 0 equipamento fotográfico é uma ação. Daí o valor desta postura e a sua justificativa fundamental para este trabalho. Logo, não está em questão registros feitos por um terceiro. Todos os registros visuais e sonoros deste trabalho são experiências e percepções do próprio pesquisador.

Caso o pesquisador participe dos eventos da paisagem na qual ele se insere, ainda podemos falar de uma escala de interferência. O pesquisador, a princípio, pode;

- participar dos eventos de uma paisagem interferindo totalmente;

- participar dos evento com pouca ou quase nenhuma interferência na paisagem.

Aqui temos dois pontos virtualmente opostos, isto significa que as duas hipóteses são virtualmente possíveis, apesar de não existirem. Estas hipóteses raramente ocorrem, salvo sob situações específicas. Isto significa que podemos ter dois sentidos na postura do pesquisador e estes sempre serão intencionais. 0 pesquisador pode optar por participar ativamente de um evento e consequentemente interferir na paisagem, ou, se afastar dos eventos interferindo o mínimo possível na paisagem. 
2.3.

práticas: visualização e percepção do espaço comum

2.1. hipóteses de percepção, análise e critica do espaço - a paisagem material e a imaterial

2.1.1. análise dos ritmos do cotidiano (Lefebvre - Rhythmanalysis)

2.1.2. paisagem de eventos (Paul Virilio e Tschumi)

2.1.3. paisagem sonora

2.1.4. body violence (Tschumi - Architecture and Disjunction)

2.2. posições do observador/pesquisador; o corpo no urbano - o corpo na paisagem

2.2.1. procedimentos analíticos do corpo na paisagem; da patologia à imersão

2.2.2. a imersão corporal paisagística e seus procedimentos operativos

2.3. práticas: visualização e percepção do espaço comum

2.3.1. considerações gerais

2.3.1.1. a fotografia

2.3.1.2. o panorama

2.3.1.3. o Podcast e o iPod

2.3.2. os experimentos

2.3.2.1. o panorama temporário ${ }^{\mathrm{MM}}$ | panorama.temporario.org

2.3.2.2. paisagens temporárias ${ }^{\mathrm{MM}}$ | temporarylandscape.com

2.3.2.3. 15 minutos $^{\mathrm{MM}}$

2.3.2.4. diárias urbanas ${ }^{\mathrm{MM}}$

2.3.2.5. podscape ${ }^{\mathrm{MM}}$

2.3.2.6. MMSoundscapes ${ }^{\mathrm{MM}}$ 
Ao inserir-se na paisagem o pesquisador a princípio precisa de "olhos e ouvidos atentos, cabeça e memória, e um coração" (LEFEBVRE, 2004, p. 36). Mas esta percepção pode ser explorada e ampliada por meio de instrumentos operativos. Estes instrumentos podem ser usados para registrar imagens e sons e é exatamente aqui que entramos na questão fundamental desta dissertação; experimentar: instrumentos sensíveis para visualizar e perceber o espaço urbano.

A fotografia é um instrumento frequentemente usado para registrar e pesquisar a vida cotidiana, entretanto o momento congelado é um problema que precisa ser solucionado. Precisamos arrumar uma alternativa que lide com a dinâmica espacial. Um meio para registrar uma paisagem de eventos, uma paisagem em constante transformação. Logo a dimensão temporal desta paisagem torna-se essencial assim como sua dimensão geométrica. A imagem aqui é da ordem do espaço socialmente produzido. É portanto uma imagem que não para. Trata-se de uma imagem dinâmica capaz de apreender um coletivo de instantes. Por conseguinte os desdobramentos da fotografia - a cronofotografia, o panorama, o cinema e o vídeo também são instrumentos que podem ser explorados.

Outro instrumento seria o registro sonoro (paisagens sonoras), a captura dos sons do ambiente urbano. 
2.3.1.

considerações gerais sobre os instrumentos utilizados

2.1. hipóteses de percepção, análise e critica do espaço - a paisagem material e a imaterial

2.1.1. análise dos ritmos do cotidiano (Lefebvre - Rhythmanalysis)

2.1.2. paisagem de eventos (Paul Virilio e Tschumi)

2.1.3. paisagem sonora

2.1.4. body violence (Tschumi - Architecture and Disjunction)

2.2. posições do observador/pesquisador; o corpo no urbano - o corpo na paisagem

2.2.1. procedimentos analíticos do corpo na paisagem; da patologia à imersão

2.2.2. a imersão corporal paisagística e seus procedimentos operativos

2.3. práticas: visualização e percepção do espaço comum

2.3.1. considerações gerais

2.3.1.1. a fotografia

2.3.1.2. o panorama

2.3.1.3. o Podcast e o iPod

2.3.2. os experimentos

2.3.2.1. o panorama temporário ${ }^{\mathrm{MM}} \mid$ panorama.temporario.org

2.3.2.2. paisagens temporárias ${ }^{\mathrm{MM}} \mid$ temporarylandscape.com

2.3.2.3. 15 minutos $^{\mathrm{MM}}$

2.3.2.4. diárias urbana MM

2.3.2.5. podscape ${ }^{\mathrm{MM}}$

2.3.2.6. MMSoundscapes ${ }^{\mathrm{MM}}$ 
Os experimentos a princípio procuram perceber descompassos entre os ritmos do cotidiano e os ritmos introduzidos nas intervenções e/ou (re)produções paisagísticas do arquiteto, designer e/ou planejador. O que está em foco é a paisagem comum, o coletivo, os espaços de encontro do cotidiano de uma metrópole.

Entretanto surge uma questão; como esta ruptura aparece, como poderá ser verificada, existe algum exemplo? Os ritmos estão presentes no nosso cotidiano ainda que muitas vezes não o notamos. Ele faz parte do vivido e nos percebemos e vivemos parte dele mas só podemos reconhecê-lo quando este se apresenta de forma irregular - um descompasso. Automaticamente ele torna-se parte do nosso juízo perceptivo. 0 ritmo de uma rua é vivido durante o nosso deslocamento, mas é apenas quando participamos de um congestionamento, uma irregularidade rítmica, é que tomamos juízo do nosso ritmo. Mas a questão rítmica não responde totalmente a questão colocada. A princípio, podemos fazer uma descrição, tipo um depoimento da minha experiência enquanto pesquisador que buscar registrar um descompasso que se dá numa ordem verbal e ampliar sua percepção com o uso da linguagem não verbal. $O$ uso da linguagem não verbal quer sejam imagens coletadas nos desdobramentos da linguagem fotográfica e da captura de áudio são 0 centro das atenções e das experiências desenvolvidas. Aqui esta linguagem torna-se um instrumento de percepção e visualização.

A crítica ao descompasso (ou neste caso específico - a falta de senso comum) é factível quando se tem um alvo específico: a produção da arquitetura contemporânea a partir das publicações de revistas e bienais, por exemplo. Basta estabelecer os parâmetros ideais e comparar com o que foi produzido. A crítica aqui seria uma patologia. Iríamos procurar os sintomas e os descompassos baseado num tratado que estabelece o que é saudável e o que não é. Seria uma crítica distanciada, pois eu, enquanto arquiteto teria que me colocar numa posição privilegiada encenando uma postura fictícia na qual eu estivesse livre - afastado - de todas as questões ideológicas e culturais que direcionam a produção contemporânea. A distância seria uma postura que daria a entender que o pesquisador jamais teria a capacidade de praticar os descompassos deliberadamente criticados. Sabemos que enquanto se adota uma postura distanciada é perfeitamente possível assumir este papel, mas ao inserirmos no contexto a nossa postura poderá ser corrompida pelo sistema cultural e ideológico. O resultado desta postura pode ser uma crítica coerente, entretanto sem uma aproximação necessária para não se correr 0 risco de se fazer uma crítica ideológica de uma ideologia. Uma ideologia para criticar e ilustrar a falta de senso comum nos espaços idealizados; projetados e até mesmo construídos.

Na prática cotidiana, o espaço comum é o espaço vivido. Logo, todo o espaço idealizado torna-se comum independente das pretensões dos seus planejadores. Independente da contribuição do (re)produtor dos espaços o cotidiano transforma, reinterpreta e absorve estes espaços e a crítica ao aproximar-se da prática revela-se frágil diante das transformações realizadas pela natureza humana. Ou seja, dependendo de quem usa ou de quem vive nos espaços a crítica pode ter mais de uma interpretação. Por este motivo, preferimos assumir uma análise critica específica e intrínseco ao espaço em detrimento de uma análise mais abrangente, genérica e extrínseca. 
Os experimentos desenvolvidos são elaborados a partir de recursos de imagem que solicitam definições e procedimentos que permitam agrupar esta série de estudos num compendio válido para a discussão dos conceitos e questões abordados por esta dissertação.

Sendo um trabalho que parte de imagens para se construir um repertório crítico para o debate, a escolha destas fontes visuais torna-se uma questão particular e específica do procedimento escolhido para 0 desenvolvimento deste trabalho. $\mathrm{O}$ trabalho se desenvolve a partir de uma postura analítica metodológica e conceitual de percepções visuais do objeto de pesquisa.

Quanto ao espaço do pesquisador ou o lugar do pesquisador na paisagem podemos apontar algumas questões; a primeira é: estamos lidando apenas com uma representação? Acredito que pode ser mais que isso. Se observarmos a representação do urbano pelos artistas e arquitetos podemos verificar que frequentemente 0 artista se coloca como um observador que parece criar na imagem um sutil distanciamento da paisagem em questão. É um olhar que está carregado de paisagens passadas que se presentificam na (re)presentificação da representação. A paisagem que é passado quando representada permanece como passado ao congelar 0 tempo. Desta forma, sem a dimensão temporal, a paisagem perde sua dinâmica eventual e passa a ser uma representação do falsa do espaço pois the falta a dimensão dinamizadora que the é estrutural. Podemos dizer que representações sem o tempo são espaços estéreis, ou seja espaços mortos, daí falsos. 
2.3.1.1.

a fotografia

2.1. hipóteses de percepção, análise e critica do espaço - a paisagem material e a imaterial

2.1.1. análise dos ritmos do cotidiano (Lefebvre - Rhythmanalysis)

2.1.2. paisagem de eventos (Paul Virilio e Tschumi)

2.1.3. paisagem sonora

2.1.4. body violence (Tschumi - Architecture and Disjunction)

2.2. posições do observador/pesquisador; o corpo no urbano - o corpo na paisagem

2.2.1. procedimentos analíticos do corpo na paisagem; da patologia à imersão

2.2.2. a imersão corporal paisagística e seus procedimentos operativos

2.3. práticas: visualização e percepção do espaço comum

2.3.1. considerações gerais

\subsubsection{1. a fotografia}

2.3.1.2. o panorama

2.3.1.3. o Podcast e o iPod

2.3.2. os experimentos

2.3.2.1. o panorama temporário ${ }^{\mathrm{MM}} \mid$ panorama.temporario.org

2.3.2.2. paisagens temporárias ${ }^{\mathrm{MM}}$ | temporarylandscape.com

2.3.2.3. 15 minutos $^{\mathrm{MM}}$

2.3.2.4. diárias urbanas ${ }^{\mathrm{MM}}$

2.3.2.5. podscape $^{\mathrm{MM}}$

2.3.2.6. MMSoundscapes ${ }^{\mathrm{MM}}$ 
Para um trabalho que pretende lidar com o espaço vivido, a paisagem habitada ou uma paisagem com eventos, a escolha dos instrumentos de registro e visualização é um ponto de partida. Quanto aos instrumentos, podemos listar: fotografia, cinema e vídeo. Como não cabe neste trabalho discutir as diferenças e potencialidades de cada um destes instrumentos, escolho o que mais me convém para discutir e experimentar suas linguagens e métodos relacionado às questões deste trabalho. Posto, a fotografia digital e seus desdobramentos serão comentados neste texto.

O instante não é apenas uma questão técnica para a fotografia, trata-se também, de uma relação com 0 espaço vivido, "uma relação com o espaço, o tempo, o corpo e o mundo" (DUBOIS, 2005 p.203). É congelar os momentos de um evento e ver o que não pode ser visto a olho nu. Conseguir visualizar um contraponto do vivido "(...) arrancado de um só golpe no continuum do real" (DUBOIS, 2005 p.203).

Apesar do trabalho de pioneiros como Etienne-Jules Marey ou Edward Muybridge, entre outros, a fotografia logo se tornou a arte e a técnica da tomada isolada, da imagem única, do congelamento de um instante temporal curto, deslocado do antes e do depois do fluxo de tempo.

(BAETENS, 2005 p.224)

O fascínio pelo instante delineou os ideais da fotografia e acabou limitando o desenvolvimento de outras possibilidades de visualização. Entretanto, se buscarmos alguns experimentos do pré-cinema, como a cronofotografia, poderemos levantar questões que parecem ter sido esquecidas pela fotografia. A cronofotografia de Etienne-Jules Marey revela uma outra possibilidade de visualização e "[...] abre dimensões que ultrapassam amplamente essa noção de instantaneidade e de análise do movimento, a que, muitas vezes, foi sistematicamente reduzida" (DUBOIS, 2005 p.203).

Assim, este trabalho, se dispõe a expor alguns experimentos em processo, situá-los num cenário entre outros autores que trataram de questões semelhantes e estabelecer um diálogo. Antes de apresentar os experimentos, precisamos rapidamente rediscutir as questões que abrangem esta dissertação introduzindo-as no corrente capítulo. $O$ espaço, o tempo e a paisagem na fotografia.

O espaço, que é uma relação dinâmica entre paisagem e eventos, e é eminentemente temporal. Isto é, dissociar o tempo do espaço seria o mesmo que ter em mãos um evento congelado ou uma paisagem morta. E é exatamente nesta paisagem atemporal, no instantâneo do evento que a fotografia generalizadamente buscou arrancar a dimensão temporal do espaço. "(...) O apogeu de uma certa idéia da fotografia: toda a espessura temporal que cerca o momento da tomada é como que anulada ou esvaziada de sua substância" (BAETENS, 2005 p.224). Esta paisagem sem o tempo, sem o evento, é uma abstração, e é exatamente aqui que se baseiam as nossas relações com o espaço, o tempo e o corpo. No exercício do projeto de arquitetura, por exemplo, precisamos eliminar o tempo, banir o corpo em atividade evitando qualquer ação (evento) que possa desestabilizar o espaço idealizado pelo arquiteto. Por outro lado, desenhar o espaço com suas mutações 
cotidianas inerentes ao espaço habitado seria uma tarefa praticamente impossível, isto, se apoiado nos métodos para lidar com o espaço que temos praticado.

É fundamentado nestas questões que os experimentos de visualização do espaço que serão apresentados foram desenvolvidos. São experimentos que buscam registrar o espaço vivido, isto é o espaço que contém o tempo. Um espaço que contém a relação dinâmica entre eventos e paisagem, fluxos e paisagem, ações e paisagem. Logo, todos os experimentos que serão apresentados e os diálogos que serão estabelecidos com outros autores, procuram insistentemente, por meio da linguagem fotográfica digital, visualizar o espaço vivido. São formas de registro que priorizam a dimensão espacial temporal podendo em alguns momentos subverter a dimensão espacial geométrica (material).

O filme Dogville (2003) de Lars Von Trier se desenvolve num cenário onde quase toda a paisagem material foi substituída por uma paisagem imaginária. Em cena restam apenas alguns objetos imediatos às ações cotidianas. $O$ que nos dá capacidade para entender a trama deste drama são as imagens (paisagens urbanas) culturalmente idealizadas. É o imaginário coletivo construído pela nossa cultura que nos permite completar a paisagem ausente. Este filme, que incorpora os recursos cênicos do teatro aplicando-os nas narrativas videográficas, nos mostra que a paisagem é antes de tudo um suporte para a vida urbana. Quem sabe podemos até acreditar que a ausência de paisagens nos permita prosseguir, já o contrário, acreditar que as construções podem subtrair a vida é tão incerto quanto elaborar um projeto pensando apenas em sua imagem culturalmente idealizada moldada num espaço geométrico desprovido de tempo. 
2.3.1.2.

o panorama

2.1. hipóteses de percepção, análise e critica do espaço - a paisagem material e a imaterial 2.1.1. análise dos ritmos do cotidiano (Lefebvre - Rhythmanalysis)

2.1.2. paisagem de eventos (Paul Virilio e Tschumi)

2.1.3. paisagem sonora

2.1.4. body violence (Tschumi - Architecture and Disjunction)

2.2. posições do observador/pesquisador; o corpo no urbano - o corpo na paisagem

2.2.1. procedimentos analíticos do corpo na paisagem; da patologia à imersão

2.2.2. a imersão corporal paisagística e seus procedimentos operativos

2.3. práticas: visualização e percepção do espaço comum

2.3.1. considerações gerais

2.3.1.1. a fotografia

2.3.1.2. o panorama

2.3.1.3. o Podcast e o iPod

2.3.2. os experimentos

2.3.2.1. o panorama temporário ${ }^{\mathrm{MM}}$ | panorama.temporario.org

2.3.2.2. paisagens temporárias ${ }^{\mathrm{MM}}$ | temporarylandscape.com

2.3.2.3. 15 minutos $^{\mathrm{MM}}$

2.3.2.4. diárias urbanas ${ }^{\mathrm{MM}}$

2.3.2.5. podscape MM $^{\mathrm{MM}}$

2.3.2.6. MMSoundscapes ${ }^{M M}$ 
Panorama foi registrado e patenteado em 1787 por Robert Barker em Londres. Eram pinturas em centros de edifícios, especialmente projetados que recebiam vistas panorâmicas em suas paredes. A iluminação era trabalhada para criar um efeito de imersão somado ao posicionamento preciso do observador por meio de uma passarela central. "[...] O panorama engaja o espectador num impressionante dispositivo espaço-temporal, que mistura arquitetura, teatro, pintura, ilusão de ótica, iluminação etc., do qual o próprio espectador torna-se 0 ponto-eixo essencial" (DUBOIS, P. 2005 p.207).

A imersão num ambiente ilusório permite ao panorama algumas características que o colocam num estado entre a fotografia e o cinema. É uma fotografia sem limites, "(...)A imagem se estende ao longo de toda a circunferência do edifício, tal modo que os extremos possam juntar-se, fechar-se e que as junções desapareçam: representação contínua, que não tem nem começo e nem fim, que não tem borda que assinale 0 limiar" (DUBOIS, P. 2005 p.209). É uma fotografia que se dá ao longo de um tempo e este tempo pode ser tanto o tempo da captura quanto o de sua leitura. É como se fosse um "plano de cinema realizado em fotografia" (DUBOIS, P. 2005 p.218). Mesmo assim, tal como o panorama não é uma fotografia ele também não é cinema. O ritmo e a construção de uma narrativa literária se dá pelo olhar do observador e não pelo direcionamento de uma câmera.

A relação com o tempo no panorama fotográfico é, evidentemente, um de seus parâmetros mais essenciais. Ao princípio habitual do instantâneo, o panorama opõe uma forma de registro do tempo radicalmente diferente. Não é exatamente o fato, por assim dizer, de capturar lapsos de tempo longos, estendidos como o espaço, mas de capturá-los progressiva e continuamente, isto é, ao deslocarem-se. É o movimento durante a tomada que é a causa de tudo. A superfície sensível dos panoramas não é impressionada, inteiramente de uma só vez, como é o caso da foto convencional, e sim sucessivamente, partindo de um extremo para se dirigir a outro, ao bel-prazer (invertido) da rotação da objetiva ou do aparelho. Existem, dessa maneira, diferentes zonas de tempo, todas contínuas, que se escalonam ao longo do panorama, fazendo com que, quando se chega ao final do percurso, encontre-se um outro momento mais tardio que 0 do começo. A variação pode ser breve ou longa segundo 0 caso. O que fica certo é que se capturou uma duração e que se inscreveu o tempo dentro da imagem, um tempo que passa, que desfila literalmente ante nossos olhos. E é claro que isso se repete para o espectador no momento da contemplação: uma foto panorâmica, à diferença de um instantâneo, não pode ser olhada com um único golpe de vista. O olho deve vê-la, isto é, percorre-la cumprindo uma travessia (na maioria dos casos da esquerda para a direita: reflexos do costume da leitura e da escrita). Esse percurso do olho leva tempo. Desenrola-se tanto no tempo quanto no espaço. O espaço do panorama, já disse, é um tempo alastrado. Entre a borda esquerda e a borda direita, corre uma duração - e ao fio desse tempo fatos podem acontecer, coisas podem modificar-se. (DUBOIS, 2005 p.219)

É exatamente nesta fresta, entre cinema e fotografia que encontramos um potencial de visualização do espaço. Alguns experimentos do pré-cinema como a cronofotografia de Marey e Muybridge também estão nesta fresta, uma fresta que está entre o registro do espaço que elimina o contínuo do tempo (fotografia) e o registro que constrói um espaço escrevendo uma linha de tempo certeira (cinema). Ambos registros são visualizações quase totalmente dirigidas e pouco abertas à construção de novas narrativas pelo leitor. Estamos buscando aqui, assim como no panorama, alternativas para visualização do espaço vivido que estejam abertas a múltiplas leituras, quantas forem possíveis. Muybridge, provou que os cavalos quando correm, por um pequeno momento, 
não tocam o chão. Muybridge e Marey, permitiram a ciência ver o que os olhos não conseguem ver. Esta segunda hipótese também é bastante desafiadora.

Assim como os panoramas, nos interessam experimentos que sejam abertos a múltiplas leituras (interativas) que nos permitam perceber o que o nosso olhar naturalmente não conseguiria. 
2.3.1.3.

o Podcast e o iPod $\AA^{26}$

2.1. hipóteses de percepção, análise e critica do espaço - a paisagem material e a imaterial

2.1.1. análise dos ritmos do cotidiano (Lefebvre - Rhythmanalysis)

2.1.2. paisagem de eventos (Paul Virilio e Tschumi)

2.1.3. paisagem sonora

2.1.4. body violence (Tschumi - Architecture and Disjunction)

2.2. posições do observador/pesquisador; o corpo no urbano - o corpo na paisagem

2.2.1. procedimentos analíticos do corpo na paisagem; da patologia à imersão

2.2.2. a imersão corporal paisagística e seus procedimentos operativos

2.3. práticas: visualização e percepção do espaço comum

2.3.1. considerações gerais

2.3.1.1. a fotografia

2.3.1.2. o panorama

2.3.1.3. o Podcast e o iPod

2.3.2. os experimentos

2.3.2.1. o panorama temporário ${ }^{\mathrm{MM}}$ | panorama.temporario.org

2.3.2.2. paisagens temporárias ${ }^{\mathrm{MM}}$ | temporarylandscape.com

2.3.2.3. 15 minutos $^{\mathrm{MM}}$

2.3.2.4. diárias urbanas ${ }^{\mathrm{MM}}$

2.3.2.5. podscape $^{\mathrm{MM}}$

2.3.2.6. MMSoundscapes ${ }^{\mathrm{MM}}$

26 iPod $($ - aparelho reprodutor de música portátil desenvolvido e fabricado pela Apple $®$. 
Podcast ou podcasting é um termo da língua inglesa usado para descrever uma coleção de tecnologias destinados à distribuição automática de programas de áudio e vídeo pela internet. Ele difere do padrão de distribuição online, o streaming - uma transmissão em tempo real -, ao transferir automaticamente, num tempo qualquer, arquivos de mídia digital ao computador do usuário para uso posterior.

A palavra podcast introduzida pelo software iTunes da Apple implica na junção das palavras iPod e broadcast. iPod é o aparelho reprodutor de áudio/vídeo digital da Apple. Broadcast, na língua inglesa significa transmissão de programas de rádio e televisão. Distinto do broadcast, em que a audiência depende de uma transmissão contínua (rádio ou TV), o podcast independe da transmissão. Para ouvir ou assistir aos programas basta o aparelho de áudio digital, o iPod ou similares.

O Podcast associado ao iPod® e suas diferenças comparado ao rádio e a TV;

1. o usuário escolhe sua programação; o que ouvir ou assistir não depende de uma programação da emissora de rádio e/ou TV.

2. estas escolhas ficam disponíveis a qualquer hora e local independente dos limites de transmissão de uma emissora; logo a escolha independe de pais, fuso-horário, etc.

3. as possibilidades de uso tem sua limitação reduzida pela portabilidade do sistema; logo pode-se ouvir e assistir aos programas no metrô, durante um vôo, numa auto-estrada, durante uma corrida, num passeio de bicicleta, andando pela cidade, etc.

A titulo de curiosidade, a palavra Pod que sugere interpretações como "Personal, On-Demand" ou foneticamente "Portable Audio", tem seu significado na língua inglesa como: parte destacável de uma aeronave, espaçonave ou veículo que possui uma função específica. Pod, por exemplo, pode ser um tanque de combustíveis sobre a asa de uma aeronave, ou, no caso de um inseto, uma bolsa com ovos. O nome iPod sugere uma parte destacável da internet com uma função específica e autônoma (a letra "i" minúscula, segundo a Apple refere-se à produtos (hardware e software) desenvolvidos para a internet; iSight, iTunes, iBook, iDVD, iLife, iPhoto, entre outros).

O termo podcast era um termo pouco preciso até a iniciativa da Apple em associa-lo ao iPod, aparelho reprodutor de áudio digital portátil que, quase simultaneamente com o podcast, se insere no mercado com um novo modelo capaz de reproduzir vídeos e visualizar fotos por um visor colorido. Uma estratégia de design e um planejamento de marketing preciso que rendeu créditos de um novo e promissor método de distribuição de mídia à Apple. Créditos merecidos apenas pela iniciativa e não pela tecnologia, o nome podcast baseado num produto da Apple populariza-se juntamente com o software iTunes e impulsioa a cultura dos podcasts. Preocupados com 0 potencial ainda pouco explorado deste método, alguns tentaram introduzir nomes alternativos como blogcasting, audioblogging e rsscasting. Entretanto o nome podcast se popularizou e tornou-se comum. 
No dia 30 de junho de 2005 a Apple $\circledR^{27}$ anunciou que em apenas dois dias os usuários do iTunes ${ }^{28}$ assinaram mais de um milhão de Podcasts do recem lançado iTunes Podcast Directory ${ }^{29}$. A popularidade desta ação pode ser confirmada com dados da própria internet. O termo podcasts se popularizou rapidamente. Doc Searls ${ }^{30}$ acompanhou os hits do Google verificando quantas vezes a palavra podcast foi pesquisada. No dia 28 de setembro de 2004 foram 24 entradas. No dia 30 de setembro o numero subiu para 526 e três dias depois chegou a 2,750 entradas. O número dobrava a cada dois dias chegando a mais de 100,000 no dia 18 de outubro. Um ano depois, o Google registrou mais de 100,000,000 de requisições para a palavra podcasts por dia.

Um podcast pode ser assinado, assim como uma assinatura do seu jornal ou revista favoritos. Assim que um podcast novo for publicado o computador do assinante receberá os arquivos disponibilizando automaticamente os novos programas. Caso o reprodutor de áudio/vídeo digital esteja, ou venha a ser conectado ao computador, o software se encarregara de atualizar automaticamente seus programas assinados no equipamento portátil (iPod). Uma assinatura de um Podcast, paga ou gratuita, permite que assim que novos programas estejam disponíveis nos diretórios de Podcast da internet, os mesmos, sejam adquiridos automaticamente pelo computador do assinante e, se desejado, também atualizado (sincronizado) automaticamente no iPod®.

Um podcast pode ser encontrado na internet utilizando-se um software podcatcher (um software que administra as assinaturas de podcasts) como 0 iTunes ${ }^{\circledR}$. Também pode ser encontrado nos sites dos podmakers (os que produzem podcasts) ou em sites de busca como o Google. Uma vez encontrado um podcast do seu interesse, você poderá ouvir ou assistir às suas últimas publicações diretamente no seu computador ou no seu iPod.

O podcast permite que produtores independentes criem e publiquem seus programas de rádio, TV,

${ }^{27}$ Apple ignited the personal computer revolution in the 1970s with the Apple II and reinvented the personal computer in the 1980s with the Macintosh. Today, Apple continues to lead the industry in innovation with its award-winning desktop and notebook computers, OS $X$ operating system, and iLife and professional applications. Apple is also spearheading the digital music revolution with its iPod portable music players and iTunes online music store.

28 iTunes $₫$ - software desenvolvido e distribuído gratuitamente pela Apple ${ }^{\circ}$ para vender, compartilhar, sincronizar e organizar arquivos de áudio e vídeo entre a internet, um computador pessoal, um CD de audio e um tocador de musica portátil (o iPod®).

"iTunes 4.9 has everything users need to discover, subscribe, manage and listen to Podcasts built in, so users can now have each new episode of their favorite Podcasts automatically delivered over the Internet to their computer and iPod $₫ "$.

"With Apple's legendary ease of use, pioneering features such as integrated Podcasting support, iMix playlist sharing, seamless integration with iPod and groundbreaking personal use rights, the iTunes Music Store is the best way for Mac and PC users to legally discover, purchase and download music online. The iTunes Music Store features more than 1.5 million songs from the major music companies and over 1,000 independent record labels, 10,000 audiobooks, gift certificates and exclusive music not found anywhere else online". (fonte: http://www.apple.com/pr/library/2005/jun/30podcast.html verificado disponibilidade em 10/12/2005)

29 fonte: http://www.apple.com/pr/library/2005/jun/30podcast.html verificado disponibilidade em 10/12/2005

${ }^{30}$ Fellow blogger and technology columnist Doc Searls 
música e vídeo sugerindo um novo método de distribuição de mídia. E este é um dos potenciais por trás deste método que, no que diz respeito à distribuição, coloca um indivíduo comum e uma rede de televisão num campo de ação até certo ponto bastante semelhantes. Exceto pela capacidade de produzir conteúdos e administrar uma comunicação de massas com maior profissionalismo e eficácia, as possibilidades de alcançar um público, uma certa audiência, são teoricamente as mesmas.

O Podcast, até 0 momento, adota uma linguagem semelhante à dos programas de rádio e TV. Entretanto 0 desenvolvimento desta linguagem e das possibilidades que a tecnologia e o método de distribuição apontam ainda foram pouco explorados.

O Podcast, assim como o rádio e a TV possuem uma espacialidade que condiciona o consumo e 0 comportamento de um grupo cultural. Entretanto, a portatibilidade deste método e a sua intensa relação com 0 corpo e com o indivíduo o tornam um condicionador do espaço social (o espaço urbano). Desta forma o iPod é potencialmente uma paisagem urbana. Uma paisagem dotada de sons e imagens que acompanham o corpo pela cidade. Uma paisagem auditiva que a partir da percepção e cognição do corpo na cidade tornam-se paisagens sonoras portáteis.

Atribuir condicionantes do desenho urbano a um objeto de design não é uma novidade introduzida pelo iPod. O automóvel, de uma forma clara, se apresenta para nós como um dos maiores condicionantes da paisagem e consequentemente do modo de vida urbano das nossas cidades. Comparações entre cidades Los Angeles e Tokyo por exemplo, a primeira priorizando o uso do carro e a segunda priorizando o transporte ferroviário (trens e metros), construíram paisagens completamente distintas e modos de vida condicionados à esta paisagem. Ao longo do século XX, Los Angeles e Tokyo ${ }^{31}$ se constituíram enquanto um laboratório de

${ }^{31}$ Carlos Garcia Vázquez no texto Visões Urbanas do Século XXI mostra como 0 automóvel e 0 trem foram responsáveis pelo desenho das grandes metrópoles, o contraponto entre Los Angeles e Tokyo é destacado a seguir;

"La importancia que la red de metro y ferrocarril de Tokyo (la mayor del mundo) ha tenido en la conformación de la ciudad es enorme. Tras la II Guerra Mundial, y a diferencia de la apuesta norteamericana por las autopistas, Japón opto por concentrar las inversiones en los transportes públicos, lo que evitó la disolución de los centros urbanos y una eclosión suburbial que no hubiera tenido precedentes. En ese momento, las compañías de ferrocarril (la mayoría de ellas privadas) comenzaron a condicionar la forma de Tokyo. Su estrategia consistía en comprar terrenos agrícolas, implantar líneas férreas y edificar conjuntos residenciales junto a las estaciones. En una sociedad en movimiento, donde vivir cerca de un apeadero es crucial, esta táctica tan solo podía estar abocada al éxito. El fractal estación de ferrocarril se convirtió así en extraño atractor, una pieza arquitectónica que haría cristalizar en torno a ella un denso y activo tejido urbano." (VÁZQUEZ, 2004 pg. 159)

"Los Ángeles es un organismo urbano tremendamente singular. Su inmenso territorio no conforma, ni mucho menos, una unidad administrativa, sino que comprende 163 ciudades y 6 condados. Esto es fruto de una particular forma de crecimiento donde muchos centros secundarios comenzaron a desarrollarse antes, y más rápidamente, que el pueblo de Nuestra Señora de Los Ángeles. Varias veces reconstruida y desplazada de sitio debido a catástrofes naturales, la antigua población española nunca logró convertirse en un claro referente territorial. La consolidación de este fenómeno y su prolongación en el tiempo derivó en la megalópoli actual: sin centro, sin límites, sin comienzo, sin final, un territorio urbanizado abierto, centrífugo, discontinuo, hiperfragmentado y sin jerarquía. (...)

Quien se empeñe en encontrar alguna "estructura" que arroje luz sobre este magma urbano tendría que acudir; indefectiblemente, a la red de autopistas. Su trazado reproduce el de líneas de ferrocarril de finales del siglo XIX, posteriormente transmitido a la red de transvías. Actualmente atraviesan la ciudad 15 autopistas: 4 de norte a sur, 4 de nordeste a sureste y 7 de oeste a este. Esta inmensa red, permanentemente ampliada y siempre colapsada, ha convertido a Los Ángeles en la capital mundial del automóvil, un hecho que ha impregnado la cultura y la forma de vida de sus habitantes. (...)" (VÁZQUEZ, 2004 pg. 100-101) 
testes que ilustra que as escolhas do design e do consumo não são nem um pouco irrelevantes para 0 planejamento urbano (a construção de uma paisagem urbana) e o condicionamento dos modos de vida. As grandes metrópoles no século XXI nos mostram que grande parte dos atributos que formam o urbano está nas mãos do design, da cultura e do consumo dirigido. Planejamento urbano não está apenas nas mãos do planejador e da legislação urbana. $O$ consumo de massas a cultura e 0 design contribuem para a produção do ambiente urbano. 0 design e o consumo de massas como desenho urbano é uma questão que 0 planejamento urbano ainda não abordou com a ênfase merecida. 
2.3.2.

os experimentos

2.1. hipóteses de percepção, análise e critica do espaço - a paisagem material e a imaterial

2.1.1. análise dos ritmos do cotidiano (Lefebvre - Rhythmanalysis)

2.1.2. paisagem de eventos (Paul Virilio e Tschumi)

2.1.3. paisagem sonora

2.1.4. body violence (Tschumi - Architecture and Disjunction)

2.2. posições do observador/pesquisador; o corpo no urbano - o corpo na paisagem

2.2.1. procedimentos analíticos do corpo na paisagem; da patologia à imersão

2.2.2. a imersão corporal paisagística e seus procedimentos operativos

2.3. práticas: visualização e percepção do espaço comum

2.3.1. considerações gerais
2.3.1.1. a fotografia
2.3.1.2. o panorama
2.3.1.3. o Podcast e o iPod

2.3.2. os experimentos

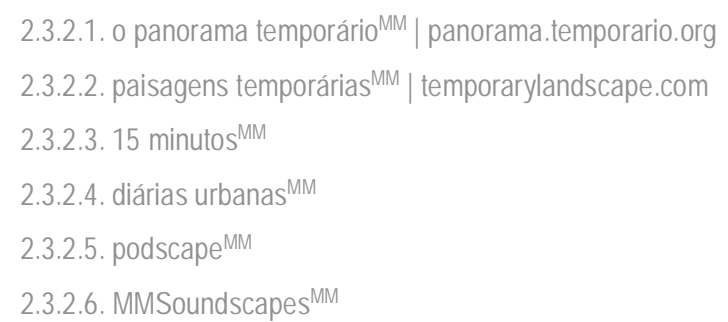


Apresentaremos aqui os instrumentos e/ou experimentos de visualização urbana desenvolvidos. Não é objetivo deste trabalho, assim como dos instrumentos apresentados chegar à uma pesquisa, ou análise urbana finalizada. $\mathrm{O}$ que estamos apresentando aqui são experimentos (possibilidades) e o que estamos propondo aqui é apresentar o seu potencial. Estes experimentos foram desenvolvidos e portanto devem ser considerados como uma ferramenta para a discussão e a sensibilização do arquiteto, do designer, do planejador, entre outros, para os condicionantes sociais e espaciais da sociedade contemporânea. Trata-se de um trabalho prático, fundamentado em argumentos teóricos-conceituais que busca um repertório crítico para se pensar a prática arquitetônica e o design no espaço urbano..

Os experimentos apresentados aqui são;

- panoramas temporários ${ }^{M M}$

- temporarylandscape.com ${ }^{\mathrm{MM}} \mid$ here, there, whre ${ }^{\mathrm{MM}}$

- 15 minutos MM

- diárias urbanas ${ }^{\mathrm{MM}}$

- podscape ${ }^{\mathrm{MM}}$

- MMSoundscapes ${ }^{M M}$

Estes experimentos são apresentados e comentados no corpo desta dissertação acompanhado por algumas ilustrações. O conteúdo completo dos experimentos se encontra no DVD-Rom e/ou nos endereços eletrônicos indicados. 


\subsubsection{1.}

o panorama temporário ${ }^{\mathrm{MM}}$ | panorama.temporario.org

2.1. hipóteses de percepção, análise e critica do espaço - a paisagem material e a imaterial

2.1.1. análise dos ritmos do cotidiano (Lefebvre - Rhythmanalysis)

2.1.2. paisagem de eventos (Paul Virilio e Tschumi)

2.1.3. paisagem sonora

2.1.4. body violence (Tschumi - Architecture and Disjunction)

2.2. posições do observador/pesquisador; o corpo no urbano - o corpo na paisagem

2.2.1. procedimentos analíticos do corpo na paisagem; da patologia à imersão

2.2.2. a imersão corporal paisagística e seus procedimentos operativos

2.3. práticas: visualização e percepção do espaço comum

2.3.1. considerações gerais
2.3.1.1. a fotografia
2.3.1.2. o panorama
2.3.1.3. o Podcast e o iPod

2.3.2. os experimentos

2.3.2.1. o panorama temporário ${ }^{\mathrm{MM}} \mid$ panorama.temporario.org

2.3.2.2. paisagens temporárias ${ }^{\mathrm{MM}}$ | temporarylandscape.com

2.3.2.3. 15 minutos $^{\mathrm{MM}}$

2.3.2.4. diárias urbanas ${ }^{\mathrm{MM}}$

2.3.2.5. podscape pM $^{\mathrm{MM}}$

2.3.2.6. MMSoundscapes ${ }^{\mathrm{MM}}$ 
conceitos

Este ensaio fotográfico é uma série de experimentos apresentados em forma de panoramas. Estes panoramas não se referem ao espaço geométrico, uma rua por exemplo, são panoramas do tempo de onde retiramos recortes temporários; panoramas temporários do tempo. É exatamente na subversão do espaço geométrico e na (hi)percepção do tempo que nos situamos. São registros do continuum temporal naturalmente sem início e fim. São visualizações que querem fugir do instante pelo continuum infinito - percepção em fuga. 0 que interessa não é só a rua, mas o que acontece nela. Este panorama poderia se entender pelas paredes de uma sala e seguir edifício a fora infinitamente. São panoramas que não tem limites, portanto qualquer apresentação seria um recorte temporário. São representações do espaço vivido que ao acompanhar o tempo se esquece dos instantes que ficaram para trás. São representações que caminham com o tempo atrás de uma efemeridade. Sempre em movimento, em tempo, impossibilitado de interromper seu percurso para acumular uma paisagem material que é uma paisagem limitada pelo início e pelo fim.

Este trabalho procura investigar outras formas de perceber e representar a vida urbana.

Espaço sem tempo, sem ações, sem eventos é um espaço vazio. É o espaço sem o corpo, uma paisagem morta. O espaço é vivo quando constituído de sua dimensão tempo, ou seja, quando uma ação ou um objeto (objetivo) o acompanha. Ainda que o objeto não seja uma ação ele é uma ação em potencial. Sempre que usamos a palavra espaço, esta vem acompanhada de uma ação; espaço de morar, espaço de dormir, etc., ou de um objeto (objetivo); espaço público, espaço privado, etc. O espaço que queremos registrar e/ou representar não é somente o espaço físico dotado de dimensões, texturas, imagens, formas e sensações, mas um espaço gerado por corpos imprevisíveis que constantemente alteram e modificam as características materiais aparentemente intactas e imutáveis do instante fotográfico.

Trata-se de registrar uma coleção de momentos, uma coleção de fragmentos do tempo que em conjunto nos possibilitam visualizar o espaço vivido. Isto é, o espaço formado pela dinâmica ininterrupta entre paisagem e eventos. São panoramas que perdem o espaço geométrico e buscam o espaço vivido, o espaço urbano.

\section{manuseando o tempo}

O registro fotográfico para a montagem destes panoramas adota alguns procedimentos específicos. As fotografias são tiradas em intervalos de tempo o suficiente para se perceber o movimento, mas ao mesmo tempo numa velocidade inferior a do cinema e do vídeo. 
O cinema trabalha com uma freqüência de projeção de 24 quadros por segundo ou 24 fps (fps=frames per second; em inglês significa quadros por segundo). Logo a câmera cinematográfica pode ser entendida como uma máquina fotográfica que tirar aproximadamente 24 fotos por segundo. Esta velocidade pode ser variável dependendo da mídia que está sendo usada e dos objetivos da produção $0^{32}$.

A percepção de movimento pelo olho humano numa seqüência de fotos é bastante razoável a partir de 12 fps, menos que isso, nosso olhar percebe a seqüência de imagens que formam o movimento. Esta percepção de movimento que nos dá entender que há uma vida, um movimento na imagem é gerada pelo mesmo instrumento de percepção que é usado para interromper, congelar o tempo. Ou seja o que nos é mostrado são imagens congeladas, a percepção de movimento é construída no nosso cérebro. Ter a sensação de fluidez temporal a partir de um recurso que a princípio interrompe o fluxo temporal nos trás esta noção de manipulação temporal. A manipulação temporal é tão complexa que até hoje a ciência não tem resposta para algumas perguntas como, por exemplo: até quantos quadros por segundo (fps) o olho humano consegue enxergar? ${ }^{33}$ Repare que esta pergunta não é o mesmo que perguntar quantos quadros por segundo eu preciso para fazer com que tenhamos a percepção de movimentos fluidos. Sabemos que a seqüência de imagens do cinema nos parece bastante fluido a 24fps e a televisão a 30fps. Alguns argumentam que freqüências superiores como $60 \mathrm{fps}$ ou 100fps apresentam animações com uma suavidade muito mais intensa do que freqüências inferiores. Estas questões ainda não têm uma resposta cientificamente precisa por dois motivos: um lado por não existir equipamentos capazes de capturar movimentos nesta velocidade (já que a indústria cinematográfica e o vídeo/tv não tiveram motivo e/ou necessidade de superar o padrão 24fps); por outro lado, devido ao fato de que esta percepção não é atribuída apenas às características fisiológicas da visão mas envolvendo, principalmente, fatores psíquicos.

32 Understanding Framerates:

Ok, so the simple definition of the framerate of a film is:

the number of still frames displayed per second = frames per second (fps)

The fps per second of a given medium depends on a number of things eg, the history and development of the medium.

Current Motion Pictures (at the cinema): $24 \mathrm{fps}$

Super 8 film: $18 \mathrm{fps}$

NTSC tv: $29.9 \mathrm{fps}$

PAL tv: $25 \mathrm{fps}$

Standard digital video $15 \mathrm{fps}$

High quality digital video $30 \mathrm{fps}$

(note: I have not considered the implications of the interlacing of tv, such that two half fields are refreshed per second. ie every second scan line...)

No need to go into the history of why motion pictures are set at $24 \mathrm{fps}$ (combo of ease, mechanics, research at the time etc etc) but that is where it sits.

You have probably heard of professional stop motion animators 'shooting on twos' or 'shooting on ones'. That is where they decide to take 2 frames at once (no movement) or 1 frame at a time.

Shooting on twos straight onto film results in a frame rate of $12 \mathrm{fps}$ (1/2 of $24 \mathrm{fps}$ ) (or $9 \mathrm{fps}$ if using super 8 film...)

fonte: http://www.brickfilms.com/viewresource.php?id=22 (verificado a disponibilidade em 06/01/2006)

${ }^{33} \mathrm{http}: / /$ www.100fps.com/how_many_frames_can_humans_see.htm (verificado a disponibilidade em 06/01/2006) 
The theory that developed to explain the phenomenon of apparent motion has been called the 'persistence of vision,' but perceptual psychologists put forward a different theory, claiming that virtually every other account to explain the phenomenon is wrong (Nichols \& Lederman 1980, p96) and that 'persistence of vision' is nothing more than a myth (Anderson \& Fisher 1978). In this essay, I look at the different optical and psychological theories explaining apparent movement in motion pictures before contrasting apparent and real movement and exploring the implications of the issue today. After all, 'upon [the persistence of vision] rests the fortune of the entire motion-picture industry' (Knight in Anderson \& Fisher 1978). (Jonathan Greenaway, 200434)

Independente das questões técnicas, fisiológicas e psíquicas que permeiam a percepção de movimento e os instrumentos de captura e reprodução de imagens o que nos interessa aqui é o manuseio temporal implícito nestes instrumentos. As possibilidades que temos aqui são instigantes. Quando a cronofotografia e todos os experimentos do pré-cinema foram criados havia uma constante motivação para se ver 0 que 0 olho não conseguiria ver, daí a manipulação do tempo por meio de uma coleção de instantes. Esta coleção de instantes, o quadro de uma fotografia, poderia ser registrado numa determinada freqüência e reproduzido em outra, assim poderíamos ver os movimentos registrados num ritmo acelerado ou reduzido. Imagine se tivéssemos uma câmera a registrar em 120 quadros por segundo o vôo de um pássaro. Agora, ao reproduzirmos este filme a 24 fps poderíamos ver e perceber movimentos do vôo e da asa do pássaro impossíveis ao olho humano. 0 manuseio do tempo aqui foi da seguinte ordem, ampliamos a velocidade percepção para depois visualizar esta percepção numa velocidade que o nosso cérebro é capaz de processar a informação visual. Este recurso não é recente e é frequentemente usado no cinema e por cientistas - basta ver os programas de televisão que mostram a vida selvagem. 0 procedimento inverso também é bastante usual, reduzir a velocidade de percepção para, por exemplo, registrar o crescimento de uma planta, ou o movimento das nuvens no céu em poucos instantes.

A velocidade de percepção instrumentalizada pela fotografia é uma questão técnica fundamental para os experimentos realizados neste trabalho. Manusear o tempo ao registrar e ao reproduzir os eventos é tão essencial quanto conceituar seus procedimentos operativos.

\section{manuseando o tempo no panorama temporário ${ }^{\mathrm{MM}}$}

O panorama temporárioMM é montado sobre o mesmo suporte e técnica do panorama de Robert Barker acrescido de tempo e do recorte temporário o que o torna independente do espaço geométrico, sendo assim, $180^{\circ}, 360^{\circ}$, etc. são apenas formas de apresentação cilíndricas e/ou recortes de um espaço que é infinito, logo temporal. Sendo assim, podemos dispor este panorama temporal em uma fita contínua ou em uma superfície cilíndrica com giros múltiplos desenvolvendo-se em espiral, aí podemos falar em panoramas de $460^{\circ}, 700^{\circ}$, $1200^{\circ}$, etc. A dimensão em graus não diz respeito a um ponto no espaço geométrico representado, mas a um espaço de tempo. Ou a vários pontos no espaço ou o movimento no tempo.

${ }^{34}$ Apparent Movement in Motion Pictures by Jonathan Greenaway, MC10220 UWA, 5/5/2004, jog3@aber.ac.uk www.aber.ac.uk/media/Students/jog0302.doc acessado em 07/01/2006 
No panorama tradicional a câmera é colocada no centro do espaço a ser registrado e uma seqüência de fotos completando um giro de até $360^{\circ}$ na horizontal e/ou na vertical é feito para que posteriormente o espaço fotografado possa ser (re)apresentado em um outro momento. Por outro lado, para o registro fotográfico do panorama temporárioMM não importa a posição da câmera nem a direção de captura da imagem. 0 que nos interessa é a freqüência com que as fotografias serão feitas. As fotografias que serão usadas para a montagem do panorama temporário ${ }^{\mathrm{MM}}$ são manipulações do tempo. Um olhar sobre o tempo, no espaço. Este experimento é um hibrido da fotografia panorâmica e do cinema. 


\section{processando o panorama temporário $\mathrm{MM}$}

llustro aqui os procedimentos técnicos e as posturas adotadas ao longo do processo do panorama temporário ${ }^{\mathrm{MM}}$ de uma avenida.

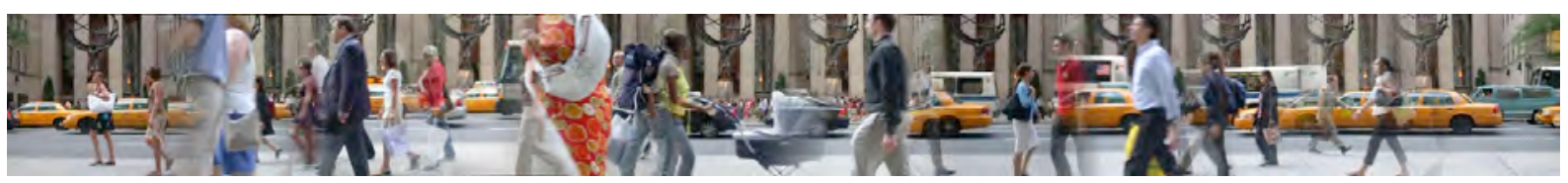

fig.5. panorama temporário de uma avenida, 5a Avenida, NY, julho 2004.

Posicionado numa calçada registrei o fluxo de pessoas e de carros da $5^{a}$ Avenida em Nova lorque por aproximadamente 40 minutos entre $13 \mathrm{hs}$ e $14 \mathrm{hs}$. Foram tiradas 102 fotografias num intervalo médio de 23 segundos para cada foto. Em quadros por segundo $0,04 \mathrm{fps}$, uma freqüência muito inferior a do cinema e a da animação. (fig.02) É uma freqüência insuficiente para se ter a percepção fluida do movimento, por outro lado, uma freqüência suficiente para se ter a percepção do fluxo e dos eventos daquele espaço naquele período de tempo.

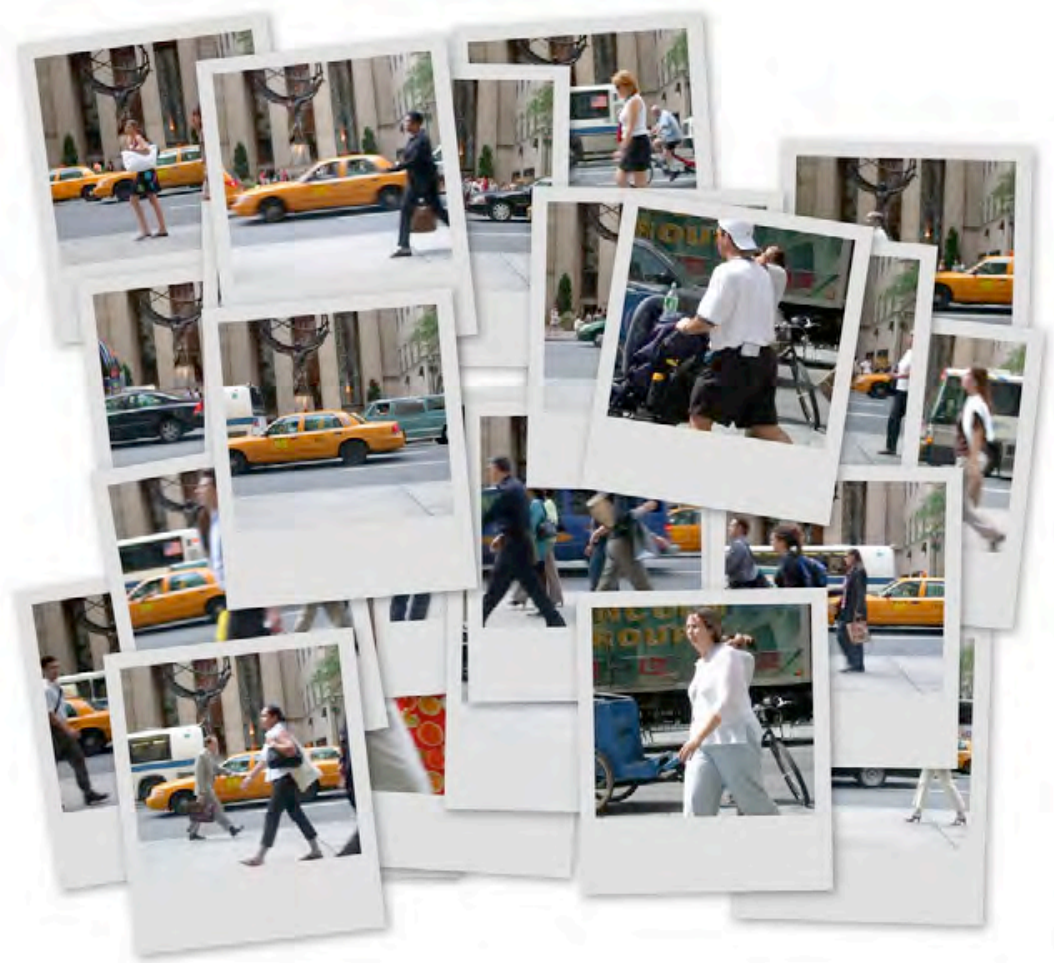

fig.6. seqüência de fotografias tiradas na 5a Avenida, NY em julho 2004.

Mas qual seria a diferença entre este registro fotográfico e a filmagem deste mesmo fluxo/evento/espaço? A princípio o cinema com a freqüência de 24 fps seria um registro muito mais completo (fluido) e portanto muito mais eficiente para compor um relato ou um experimento. 
Imaginemos a cena entre o homem da cronofotografia e os Lumière, por exemplo, ao sair de uma das primeiras sessões do cinematógrafo. Marey, de um lado, declarando não encontrar nenhum interesse na invenção dos dois irmãos, uma vez que esta apenas reproduz aquilo que, de toda maneira, o olho já vê tal como é, na percepção natural. O cinematógrafo, para ele, é puro mimetismo. Não oferece nada a mais ou nada melhor ao que se vê e já se sabe. Não pertence ao leque das ferramentas que permitem ir alem do visível (perceptivo), de descobrir o alem das aparências, de ultrapassar o estágio do olho comum para esperar chegar e atingir uma 'visão superior' qualquer (desenbocando num saber novo do real). No seu ponto de vista, assim, o cinematógrafo é, realmente, 'uma invenção sem futuro', ao passo que sua descoberta, a cronofotografia, permite justamente ver mais além, ver diferentemente, ver 0 que 0 olho não pode ver no estado normal. Tratando-se do movimento, observar o detalhe, enfim dado ao conhecimento (por meio da parada sobre a imagem) da locomoção animal ou humana. Decompor, parar o fluxo ('a vida') para ver melhor, para, em todo caso, ver o que nunca se tinha visto verdadeiramente, nunca assim, eis o que interessa a Marey mais do que qualquer outra coisa.

Não se pode esquecer que o trabalho de Marey, no fim do século XIX, é plenamente contemporâneo a inúmeros movimentos científicos (e a cientistas também) que ambicionaram fazer ver e entender o que foi até então apenas trevas ou mistérios, e que alocam nos instrumentos técnicos, no dispositivo fotográfico em particular, uma potência inquisitiva e reveladora muito grande, para não dizer, às vezes, desmedida. (DUBOIS, 2005, p.204)

Quanto a radical opinião de Marey; sabemos muito bem que o cinema tem um potencial muito grande.

Mesmo que o mimetismo ainda seja o seu objetivo principal, o cinema possui uma linguagem que vem sendo amplamente explorada. No nosso caso, o panorama temporário ${ }^{\mathrm{MM}}$ aborda uma outra relação de registro/percepção, uma relação que não cabe discutir se é mais adequada e/ou eficiente que o cinema. Se estamos trabalhando uma manipulação temporal, assim como os experimentos do pré-cimena, estamos buscando outras formas de perceber e visualizar. No caso do panorama, o registro do fluxo da avenida nos permite congelar alguns instantes sem congelar 0 fluxo. Ao congelar 0 instante podemos observar com mais precisão 0 andar das pessoas, o que elas carregam, como se vestem, se estão falando ao celular enquanto andam, se estão sozinhas, etc. (fig. 03) Estas observações, detalhes das ações, não seriam possíveis num registro de 24 quadros por segundo. Os instantes passariam rápidos demais e não seríamos capazes de perceber tais detalhes. Tais detalhes ainda, são possíveis apenas pelo registro fotográfico. Com a câmera digital conseguimos imagens de mais de 3 mil pixels (pontos) de largura enquanto que a câmera filmadora digital nos daria uma imagem de no máximo 1 mil pixels (pontos) de largura. A imagem da fotografia digital nos permite uma ampliação, um zoom na imagem muito mais potente que o da filmadora digital. 

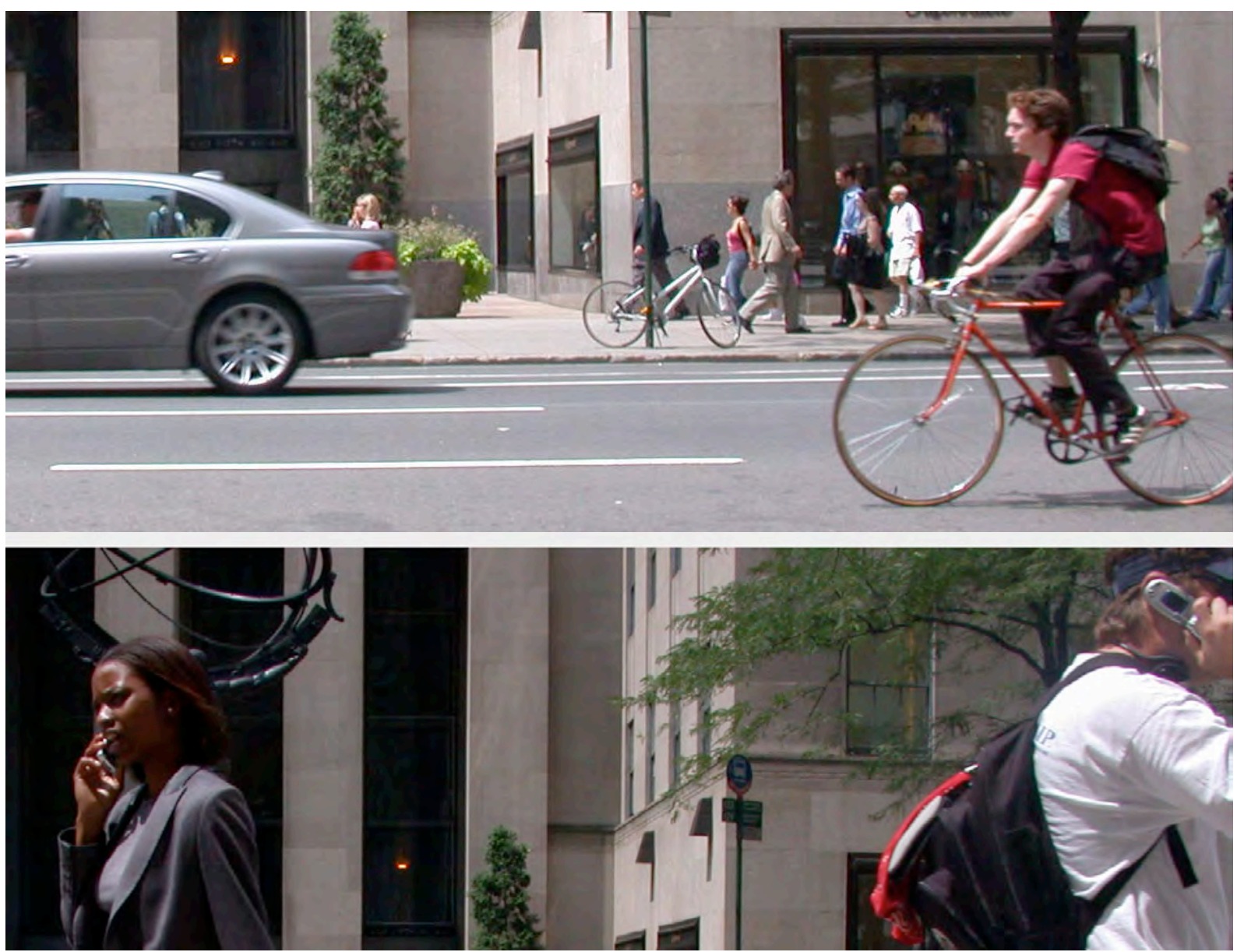

fig.7. detalhe das fotografias.

panoramas temporários ${ }^{\mathrm{MM}}$ | panorama.temporario.org

Os panoramas temporários ${ }^{\mathrm{MM}}$ listados abaixo foram produzidos entre 2004 e 2005 e fazem parte deste trabalho;

- panorama temporárioMM de uma avenida - 5th Avenue, NY, julho 2004.

- panorama temporárioMM de um almoço - Columbus Center, NY, julho 2004.

- panorama temporárioMM de uma loja de departamentos - Times Square, NY, julho 2004.

- panorama temporárioMM de uma jornada de metrô - estações e trens do metro, NY, julho 2004.

- panorama temporárioMM de uma rua - Coronel Fabriciano, MG, abril 2005

- panorama temporário ${ }^{\mathrm{MM}}$ de uma mercearia - Coronel Fabriciano, MG, abril 2005.

- panorama temporárioMM de um aeroporto - Congonhas, SP, junho 2005.

- panorama temporárioMM de uma esquina - Soho, NY, julho 2004.

- panorama temporárioMM de um parque - Central Park, NY, julho 2004. 
Os panoramas são apresentados em 2 meios: em fotografia impressa sobre papel e em formato digital interativo incluso no DVD-Rom, ambos anexados no corpo deste trabalho. O formato digital interativo também encontra-se publicado no site http://panorama.temporario.org. As fotografias impressas encontram-se no anexo.

O formato digital é uma interface que simula um ambiente tridimensional. A visualização, quando auxiliada pela ferramenta de zoom permite a observação de detalhes das imagens que não são possíveis no formato impresso. 
2.3.2.2.

paisagens temporárias ${ }^{\mathrm{MM}}$ | temporarylandscape.com

2.1. hipóteses de percepção, análise e critica do espaço - a paisagem material e a imaterial

2.1.1. análise dos ritmos do cotidiano (Lefebvre - Rhythmanalysis)

2.1.2. paisagem de eventos (Paul Virilio e Tschumi)

2.1.3. paisagem sonora

2.1.4. body violence (Tschumi - Architecture and Disjunction)

2.2. posições do observador/pesquisador; o corpo no urbano - o corpo na paisagem

2.2.1. procedimentos analíticos do corpo na paisagem; da patologia à imersão

2.2.2. a imersão corporal paisagística e seus procedimentos operativos

2.3. práticas: visualização e percepção do espaço comum

2.3.1. considerações gerais
2.3.1.1. a fotografia
2.3.1.2. o panorama
2.3.1.3. o podcast

2.3.2. os experimentos

2.3.2.1. o panorama temporário ${ }^{\mathrm{MM}} \mid$ panorama.temporario.org

2.3.2.2. paisagens temporárias ${ }^{\mathrm{MM}}$ | temporarylandscape.com

2.3.2.3. 15 minutos $^{\mathrm{MM}}$

2.3.2.4. diárias urbanas ${ }^{\mathrm{MM}}$

2.3.2.5. podscape $^{\mathrm{MM}}$

2.3.2.6. MMSoundscapes ${ }^{\mathrm{MM}}$ 


\section{conceito}

here, there, where ${ }^{\mathrm{MM}}$ é um projeto de multimídia interativo na internet para compartilhar experiências urbanas agrupando textos, sons e imagens. Textos ativam sons, imagens ativam sons, textos ativam imagens, imagens ativam sons e assim por diante em combinações infinitas e randômicas. Uma fusão das linguagens visual, auditiva e escrita, é apresentado simultaneamente numa seqüência não linear. Trata-se de uma visualização múltipla, imprevisível e suscetível a interpretações individualizadas que sob alguns aspectos é uma referência ao caminhar pelas ruas de uma cidade. 0 multimídia desenvolvido em $\mathrm{htm} /$ para a internet tem a possibilidade de ser constantemente alimentado com novas experiências urbanas e gradualmente ir construindo um repertório de experiências. Este repertório pode ser reciclado, ampliado, eliminado, etc. O próprio processo de formação e (de)formação é uma referência à efemeridade e à mutação da experiência urbana. As experiências são compartilhadas por loops de fotos, panoramas, panoramas temporários ${ }^{\mathrm{MM}}$, soundscapes, textos, músicas, vídeos e filmes.

Este projeto interativo poderá ser constantemente alimentado por informações que estão sendo coletadas. Ele se produz e (re)produz assim como o nosso modo de vida urbano. O projeto here, there, wheremM é um experimento representacional que busca abordar o confronto do corpo no espaço e a sua ocupação do espaço.

[...] Antes de produzir efeitos no mundo material (ferramentas e objetos), antes de produzir a si mesmo provendo-se do sustento do meio, e antes de (re)produzir a si mesmo gerando outros corpos, cada corpo vivo é espaço e tem espaço: ele produz a si mesmo no espaço assim como produz este espaço. (LEFEBVRE, H. 1974 p. 170).

Procuramos não somente representar a cidade, mas também estudar a sua produção e reprodução através de seus corpos vivos. Neste momento, nosso objeto é o cotidiano da vida metropolitana. Tempo é distinto, mas não separado do espaço, logo, o primeiro passo deste experimento é procurar por formas de registrar e representar o espaço/tempo no confronto entre corpo e metrópole. Talvez, uma outra forma de vivenciar o cotidiano metropolitano.

\section{o projeto}

Este projeto não é um experimento científico, e nem uma pesquisa metodologicamente formatada. Ele é entendido como um projeto experimental que abre possibilidades para leitura e representação das dinâmicas espaciais urbanas. Tratasse de um projeto interativo, não linear e dispensado de toda e qualquer forma de narrativa pré-concebida. 
Este experimento está entre um cd-room multimídia e um website. Enquanto cd-room, ele não poderia ser freqüentemente alimentado por novas informações; enquanto website; dispensa muito tempo no download de todos os panoramas, sons, musicas e vídeos associados a este sistema. Neste momento, a internet é muito lenta para viabilzá-lo, o que é momentâneo. A tecnologia para a internet não é a nossa questão neste momento. Então, estamos entre-meios aqui.

O projeto here, there, where ${ }^{\mathrm{MM}}$ pode ser visto no DVD-Rom em anexo ou na internet em http://here.temporarylandscape.com/. Anexo no fim da dissertação algumas imagens do multimídia em funcionamento capturadas da tela do computador. 
2.3.2.3.

15 minutos $\mathrm{MM}$

Sistema Operativo para uma Cartografia Temporária do Espaço

2.1. hipóteses de percepção, análise e critica do espaço - a paisagem material e a imaterial

2.1.1. análise dos ritmos do cotidiano (Lefebvre - Rhythmanalysis)

2.1.2. paisagem de eventos (Paul Virilio e Tschumi)

2.1.3. paisagem sonora

2.1.4. body violence (Tschumi - Architecture and Disjunction)

2.2. posições do observador/pesquisador; o corpo no urbano - o corpo na paisagem

2.2.1. procedimentos analíticos do corpo na paisagem; da patologia à imersão

2.2.2. a imersão corporal paisagística e seus procedimentos operativos

2.3. práticas: visualização e percepção do espaço comum

2.3.1. considerações gerais
2.3.1.1. a fotografia
2.3.1.2. o panorama
2.3.1.3. o Podcast e o iPod

2.3.2. os experimentos

2.3.2.1. o panorama temporário ${ }^{\mathrm{MM}} \mid$ panorama.temporario.org

2.3.2.2. paisagens temporárias ${ }^{\mathrm{MM}}$ | temporarylandscape.com

2.3.2.3. 15 minutos $^{\mathrm{MM}}$

2.3.2.4. diárias urbanas ${ }^{\mathrm{Mm}}$

2.3.2.5. podscape $^{\mathrm{MM}}$

2.3.2.6. MMSoundscapes ${ }^{\mathrm{MM}}$ 


\section{sobre o trabalho}

15 minutos $^{\mathrm{MM}}$ é o nome dado ao trabalho desenvolvido juntamente com a professora Ana Paula Assis para 0 Atlas do Vale do Aço ${ }^{35}$, projeto de pesquisa do grupo Cartografias Urbanas ${ }^{36}$ do Curso de Arquitetura e Urbanismo do UnilesteMG ${ }^{37}$. Este trabalho participou da mostra itinerante do CICLO de Arquitetura e Urbanismo ${ }^{38}$ em 2004

\section{conceito}

Partindo dos mesmos conceitos e procedimentos adotados nos panoramas temporários ${ }^{\mathrm{MM}}$, neste experimento, aplicamos o recorte temporário a algumas situações específicas do Vale do Aço. 15 minutos ${ }^{\mathrm{MM}}$ foi o recorte temporário médio dos experimentos. Neste recorte temporário procuramos perceber as características eventuais de alguns espaços urbanos. 0 modo de vida dos habitantes focado na mobilidade urbana foi o centro da análise.

Quanto tempo gasto até Coronel Fabriciano? ou A quanto tempo de distancia está Coronel Fabriciano? A questão que nos é apresentada a todo o momento, expressada de maneira coloquial, coloca-nos diante de uma situação recorrente no nosso cotidiano. O tempo é um meio para se dimensionar o espaço tão importante quanto a distância. A poucos interessa saber quantos quilômetros separam lugares, mais valem os preciosos minutos dispensados ao longo do deslocamento.

A ampliação das possibilidades e disponibilidades dos sistemas de transportes combinado às redes de

35 Subvertendo o caráter tradicional do mapa, bem como o de sua compilação - o Atlas - o PROJETO ATLAS_VALE DO AÇO se coloca como um objeto crítico da região focada, apresentando e mapeando a lógica por detrás das representações cotidianas no Vale do Aço. Isto será feito a partir do levantamento crítico não só de aspectos físicos da região de estudo, mas também culturais, econômicos, políticos e sociais, utilizando-se de representações interativas produtoras de análises subjetivas e mais abrangentes. Sendo o PROJETO ATLAS_VALE DO AÇO uma radiografia do cotidiano tomando como ponto de partida o espaço e suas componentes sociais, políticas, econômicas e sociais; este tem de ser um retrato do momento onde 0 território se insere dentro da lógica tanto local quanto global.

O Vale do Aço é um pólo industrial do aço e da celulose situada no vale do Rio Doce, Minas Gerais. O Vale do Aço é formado pelos municípios de Timóteo, Coronel Fabriciano, Ipatinga e Santana do Paraíso.

36 O grupo Cartografias Urbanas se apresenta como local de convergência de debates e pesquisas acerca das dinâmicas urbanas notadas no Vale do Aço ao longo de sua história e das estratégias de intervenção sobre esse espaço e suas complexidades geográficas, econômicas, sociais, políticas, ambientais. Partindo das linhas de pesquisa estabelecidas pelo grupo - Dinâmicas Urbanas, Visualizações Complexas e Estratégias de Intervenção e Gestão do Espaço - pretende-se a documentação, a representação e a intervenção, respectivamente, tendo como eixo as sucessivas reconfigurações territoriais da região objeto de estudo.

${ }^{37}$ CAU/UnilesteMG. Curso de Arquitetura e Urbanismo do Centro Universitário do Leste de Minas Gerais. www.unilestemg.br/arquitetura/.

38 "O CICLO de Arquitetura e Cultura é um processo contínuo de agenciamento de diversas práticas, programas e propostas que ampliem as possibilidades da experiência, da produção, da intervenção, da organização e da gestão espacial e material em todas as suas escalas. Tem como proposta o rastreamento, o reconhecimento, o debate, a divulgação e a exibição da produção de uma cultura arquitetônica e urbana, através de exposição itinerante, seminário, publicações gratuitas e vídeos. O CICLO, de periodicidade anual, pretende divulgar e disseminar formas que expandam o cânone de produção da arquitetura, do urbanismo e da paisagem, e que sejam potencialmente transformadoras das relações sociais, políticas, culturais e ecológicas do cotidiano das cidades brasileiras." fonte: (http://www.ciclos.org.br/ verificado a disponibilidade em 13/01/2006) 
informação nos oferece uma noção de proximidade desvinculada das unidades de medida espaciais. Estes sistemas eficientes de deslocamento de corpos físicos e corpos informacionais multiplicam a possibilidade de deslocamento e participação espacial pela tele-presença. Pelo sistema de deslocamento aéreo é possível tomar café da manhã em Porto Alegre, almoçar em São Paulo, jantar em Manaus e dormir em Bogotá. Com um equipamento de teleconferência é possível reunir empresários em Tókio com investidores em Los Angeles e arquitetos em Londres. Com uma noite dormindo num ônibus posso acordar em São Paulo. Uma noite dormindo num avião acordo em Nova lorque.

Se a variável tempo assume tal relevância na fruição e percepção dos espaços contemporâneos, por que também não assumi-la como representação deste mesmo espaço? Colocada a questão de tal maneira, buscamos definir um instrumental capaz de gerar uma abordagem cartográfica que considerasse o tempo como uma variável qualitativa do espaço vivido. 


\section{processando 15 minutos ${ }^{\mathrm{MM}}$}

Produzimos durante estes ensaios fotográficos, seqüências de fotos e panoramas temporários ${ }^{\mathrm{MM}}$ das seguintes situações;

- situação 1 - esquina da Rua Belo Horizonte, Caladinho, Coronel Fabriciano.

- situação 2 - trevo acesso ao bairro Cidade Nobre, BR-381, Ipatinga.

- situação 3 - o deslocar de ônibus do bairro Horto, Ipatinga ao bairro Caladinho, Coronel Fabriciano.

Todas as situações foram registradas por aproximadamente 15 minutos. Para o registro foram utilizados simultaneamente 2 máquinas fotográficas e uma câmera de vídeo. Assim os eventos de cada situação foram registrado por 15 minutos de dois ou mais pontos de vista. 0 deslocamento de ônibus também se deu num período de 15 minutos.

O procedimento e a forma de lidar com os instrumentos deste trabalho, assim como os demais experimentos apresentados nesta dissertação não pretendem ser experimentos conclusivos. Ainda que aqui coloquemos algumas das nossas percepções, ressalto que o registro está aberto a outras percepções e múltiplas leituras.

$\mathrm{Na}$ situação 1 por exemplo, oferecemos um retrato do cotidiano de um bairro periférico percebido aqui não como periferia de Coronel Fabriciano, mas como periferia do Vale do Aço. Aqui moram trabalhadores das usinas de Timóteo, de Ipatinga e Santana do Paraíso. Neste breve ensaio fotográfico podemos perceber que muitos dos funcionários da USIMINAS ${ }^{39}$ que moram neste bairro usam a bicicleta para ir trabalhar. Estes podem ser facilmente identificados pelo uniforme cinza da usina. A bicicleta é um meio de transporte muito usado neste bairro. Na situação 2, identificamos os mesmos funcionários da usina, só que desta vez de moto. Os funcionários que andam de moto moram nos bairros de Ipatinga. Ipatinga, por sua vez, é uma cidade planejada e possui bairros dispersos e largas avenidas. Seus moradores usufruem de infra-estrutura numa media acima da maioria dos municípios brasileiros, inclusive, Coronel Fabriciano. Os moradores do bairro Caladinho não usufruem de uma infra-estrutura adequada, constantemente o bairro é alagado e não possui saneamento, pavimentação e drenagem na grande maioria de suas ruas. Na situação 3 podemos perceber durante 0 trajeto a quantidade de pessoas que usam a ciclovia às margens da BR-381, não são apenas os funcionários da USIMINAS. Neste trajeto de 15 minutos nenhum passageiro entrou ou saiu do ônibus. Pareceu-me que o ônibus era uma opção para trajetos de acima de 15 minutos, também percebeu-se que os deslocamentos entre os bairros do Vale do Aço são longos, gasta-se um bom tempo nos deslocamentos. Vale lembrar que os deslocamentos são intermunicipais. Podemos perceber na situação 2 o fluxo de carros, quantos são os carros que estão passando pelo Vale do Aço em viajem e quantos estão usando a BR-381 para deslocamento local. Podemos observar o perfil das pessoas que andam de carro, os tipos de carros e como as pessoas andam.

39 Usina Siderúrgica situada em Ipatinga-MG. www.usiminas.com.br 
Enfim, observar como as pessoas se deslocam, para onde vão, suas escolhas, como se vestem e como andam pode nos dizer muita coisa.

Anexo no fim da dissertação os ensaios fotográficos e os panoramas montados para o trabalho 15 minutos $^{M M}$. No DVD-Rom em anexo encontram-se as fotografias em formato digital deste trabalho 
2.3.2.4.

diária urbana $\mathrm{MM}$

a experiência da habitação num sistema urbano

2.1. hipóteses de percepção, análise e critica do espaço - a paisagem material e a imaterial

2.1.1. análise dos ritmos do cotidiano (Lefebvre - Rhythmanalysis)

2.1.2. paisagem de eventos (Paul Virilio e Tschumi)

2.1.3. paisagem sonora

2.1.4. body violence (Tschumi - Architecture and Disjunction)

2.2. posições do observador/pesquisador; o corpo no urbano - o corpo na paisagem

2.2.1. procedimentos analíticos do corpo na paisagem; da patologia à imersão

2.2.2. a imersão corporal paisagística e seus procedimentos operativos

2.3. práticas: visualização e percepção do espaço comum

2.3.1. considerações gerais

2.3.1.1. a fotografia

2.3.1.2. o panorama

2.3.1.3. 0 podcast

2.3.2. os experimentos

2.3.2.1. o panorama temporário ${ }^{\mathrm{MM}} \mid$ panorama.temporario.org

2.3.2.2. paisagens temporárias ${ }^{\mathrm{MM}}$ | temporarylandscape.com

2.3.2.3. 15 minutos ${ }^{M M}$

2.3.2.4. diárias urbanas ${ }^{\mathrm{MM}}$

2.3.2.5. podscape $^{\mathrm{MM}}$

2.3.2.6. MMSoundscapes ${ }^{\mathrm{MM}}$ 
Este experimento é um relato crítico de uma experiência urbana baseado em hipóteses eventuais. 0 objetivo é experimentar o urbano a partir de uma proposta de hipóteses estéticas relatando esta experiência. A proposta seria a possível hospedagem de um indivíduo por 24hs no sistema urbano ${ }^{40}$ e 0 cálculo de sua tarifa - custo da hospedagem. A hospedagem por sua vez seria por si só um evento urbano inerente às dimensões físicas e temporais do espaço.

A apresentação deste experimento acontece em 3 etapas, ou momentos:

$1^{\mathrm{a}}$ etapa: a construção de hipóteses críticas à respeito da hospedagem.

$2^{\mathrm{a}}$ etapa: o relato de uma experiência/hospedagem no sistema urbano.

$3^{a}$ etapa: a produção de um vídeo paralelo à experiência relatada.

\section{$1^{\text {a }}$ etapa;}

uma hipótese para tarifar a diária do sistema urbano

A diária urbana é calculada levando-se em consideração 3 dimensões de hospedagem: 0 deslocamento $[\mathrm{km}]$, a duração [horas] e o consumo [r\$]. Para efeito de cálculo as unidades de medida de cada uma destas dimensões serão respectivamente: kilômetro [km], horas [hs] e reais [r\$]. Sendo assim adotaremos as seguintes dimensões:

- deslocamento $[\mathrm{km}]$

- duração [hs]

- consumo $[\mathrm{r} \$]$

O evento urbano, ou, a hospedagem no sistema urbano, além de possuir 3 dimensões quantitativas para efeito de cálculo matemático possui também uma dimensão social caracterizada por modos ou modulações. As modulações dos eventos urbanos adotados são 2:

- encontros

- desencontros

sobre as modulações: encontros e desencontros

A socialização entre os hóspedes do sistema urbano pode se dar em qualquer uma das dimensões da hospedagem modulados em encontros e desencontros.

"O encontro de estranhos é um evento sem passado. Freqüentemente é também um evento sem futuro (o esperado é não ter futuro), uma história para não ser continuada." (Bauman, 2001, pg. 111).

\footnotetext{
40 o sistema urbano é o espaço comum, o espaço compartilhado pelos indivíduos moradores da cidade.
} 
O encontro de estranhos é o evento sem passado e uma história para não ser continuada, como coloca Bauman, neste caso preferimos substituir a palavra encontro por desencontros para caracterizar esta experiência comum. Nesta substituição de palavras não podemos deixar de explicitar a referência à experiência urbana ilustrada por Sofia Coppola no filme Lost in Translation ${ }^{41}$ (2003).

Os encontros são os momentos onde as relações têm um fim que vão além da instantânea e efêmera hospedagem. Sendo assim, solicitam do hóspede deste sistema a manutenção da estadia. Esta manutenção significa registrar na memória. O encontro passa a ser um evento relativo à percepção consciente.

Ainda que a duração do encontro não possa ser mantida em virtude do deslocamento, o encontro permanece na memória. Sendo assim, a repetição de um encontro, quantas vezes forem possíveis, desejados e/ou necessários é a manutenção de uma duração específica.

Por outro lado, os desencontros não possuem memória. É uma percepção inconsciente. Eles acontecem quando a duração de um evento urbano (a hospedagem) não teve um fim específico tendo um fim apenas operacional e/ou habitual.

\section{sobre as dimensões quantitativas}

O deslocamento refere-se à amplitude de apreensão do sistema urbano. Quanto mais um indivíduo se deslocar, mais amplo será sua participação no sistema urbano.

A duração refere-se aos momentos de repouso no sistema. São pausas essenciais para produção e/ou recuperação ocorrendo na maioria das vezes num ritmo natural dado pelo próprio indivíduo. Entretanto a duração pode ser imposta pelo sistema urbano num momento de desequilíbrio, insustentabilidade e/ou saturação. Neste caso o hóspede urbano é involuntariamente submetido a uma duração desconfortável. Neste caso 0 indivíduo torna-se muito mais sensível à percepção de uma duração. Ao assistir um filme no cinema a percepção de duração é muito menos sensível do que numa jornada num ônibus lotado, por exemplo.

A duração refere-se também ao sustento da atividade urbana que se dá: por recursos energéticos para os componentes mecânicos (carros, eletrodomésticos, equipamentos eletrônicos, etc.), por recursos humanos e culturais que dinamizam e instrumentalizam o sistema. A duração tem um papel fundamental no custo e na sustentabilidade do sistema. A duração pode tornar um determinado evento urbano insustentável simplesmente

41 O filme "Lost in Translation" de Sofia Coppola foi lançado no Brasil com o titulo Encontros e Desencontros. A relação e a experiência urbana temática deste filme é uma referência direta para este trabalho pois retrata a relação entre estranhos e desconhecidos no cotidiano urbano de uma metrópole, no caso; Tóquio. 
por acarretar altos custos devido a um consumo energético de longa duração. Este consumo energético de grande duração pode ser tanto de recursos materiais quanto de recursos humanos.

O consumo é uma dimensão que está diretamente ligado à duração. A duração de um evento urbano (a hospedagem) está diretamente relacionado ao valor de consumo. Logo, hospedagens (eventos urbanos) que demandam uma longa duração de consumo de recursos humanos e/ou materiais naturalmente terão valores mais elevados.

o cálculo: $[\mathrm{DT}]$ = [dinâmicas temporárias]

Para se calcular o valor de uma diária da hospedagem num sistema urbano vamos adotar a seguinte fórmula: multiplica-se o deslocamento [km] pela duração [horas] e pelo consumo [r\$].

$\mathrm{Km} \times$ horas $\mathrm{x} \mathrm{r} \$=\mathrm{km} . \mathrm{hs} . \mathrm{r} \$$.

Considerando que tempo possui um valor monetário dentro do sistema produtivo urbano, logo hs e r\$ podem ser considerados como uma variável temporal. hs. $\$$ = tempo $[T]$. Se km refere-se a distância que inclui o deslocamento que é dinamizador do sistema adotaremos a variável [D].

Logo nossas diárias serão calculadas em [DT] = [dinâmicas temporárias].

Pela fórmula podemos deduzir que as hospedagens com maior amplitude de deslocamento tendem a custar mais que as hospedagens com menor ou nenhum deslocamento e as diárias mais caras são aquelas que possuem o maior deslocamento numa determinada duração. Entretanto, esta constatação não é válida para os indivíduos que tem a sua forma de produção no deslocamento (ou seja que possuem o consumo nulo) ex: motoristas de ônibus, caminhoneiros, pilotos e comissários de bordo. Neste caso, o valor do consumo seria igual a zero o que resultaria em um DT nulo; ex:

[100 km x 1 hs $\times 0$ or\$ $[0,0 D T]$

\section{$2^{\mathrm{a}}$ etapa}

uma diária urbana - estudo de caso: Belo Horizonte > São Paulo > Coronel Fabriciano em 24hs

\section{Domingo, Belo Horizonte, 22:25.}

O auto falante do terminal rodoviário de Belo Horizonte anuncia: "atenção senhores passageiros, faltam 5 minutos para a próxima partida, ocupem seus lugares". Logo, dirijo-me ao ônibus para ocupar o meu lugar. Antes, cumprimento o motorista do ônibus com uma boa noite e ele me 
retribui - "tenha uma boa viagem" - no mesmo tom que ele repetiu para os 36 passageiros daquela noite, para os 252 da semana, para os 1.008 do mês e para os 12.096 do ano. Ao ocupar o meu lugar, identifico visualmente o meu companheiro do assento ao lado, vamos dormir e passar uma noite juntos praticamente com a mesma certeza de que nunca mais nos encontraremos novamente, então é melhor dormir durante toda a viagem evitando eventuais conversas. Não se trata de uma antipatia, é apenas uma preguiça de fazer 'amigos descartáveis' (amigos descartáveis: amigos que você tem por um período de tempo necessariamente conveniente, geralmente ao longo da duração de um deslocamento e/ou consumo e que provavelmente nunca mais será visto.

[665km x 8hs x 105r\$)] [558.600,00 DT]

\section{São Paulo, segunda, 05:55.}

Deixo o ônibus ainda um pouco sonolento e caminho por entre fluxos de pessoas em motion blur. Por 5 minutos não consigo enxergar bem e ando entre vultos. Quando consigo enxergar perfeitamente já estou na estação na plataforma do metrô. Embarco, ocupo um lugar, encosto a cabeça na bolsa e durmo mais um pouco.

$[11 \mathrm{~km} \times 0,3 \mathrm{hs} \times 2,10 \mathrm{r} \$[6,93 \mathrm{DT}]$

\section{6:35, São Paulo, estação do metrô Ana Rosa.}

Acordo pela segunda vez em São Paulo. Desta vez faço uma pequena caminhada até em casa. Casa local de encontro. Local onde a duração de algumas memórias é mantida e ao mesmo tempo referencia o deslocamento.

$[1 \mathrm{~km} \times 0,2 \mathrm{hs} \times$ Or $\$[0,00 \mathrm{DT}]$

\section{7:00, São Paulo, casa.}

Dormir, banhar, comer, conversar, ler jornal.

[0 km $\times 1 \mathrm{hs} \times 10 \mathrm{r} \$[0,00 \mathrm{DT}]$

\section{8:45, São Paulo, estação do metrô Ana Rosa.}

O sistema de metrô da cidade de São Paulo transporta 1,7 milhões de pessoas por dia. Isto não é muito, trata-se de um sistema ainda muito pequeno perto da demanda existente. Nova York, por exemplo, com uma população inferior a São Paulo, possui um sistema que transporta mais de 9 milhões por dia.

Eu e mais 1.699.999 paulistanos nos dirigimos para um desencontro coletivo. As conversas devem ser evitadas, trocar olhares pode ser constrangedor. Ler um livro ou olhar para o sistema de ventilação no teto do trem é uma alternativa.

[10km x 0,6hs x 3,80r\$] [22,80DT] 


\section{9:25, São Paulo, FAU, rua Maranhão.}

Aula na pós-graduação, as mesmas pessoas o mesmo encontro. Conversas, idéias e café no intervalo. Uma hospedagem que fica na memória e permanece.

$[0,3 \mathrm{~km} \times 4 \mathrm{hs} \times 4 \mathrm{r} \$][4,80 \mathrm{DT}]$

12:42, Consolação, ônibus, metro, táxi.

O corredor de ônibus que a prefeitura de São Paulo fez no eixo Consolação-Rebouças é incrível. Os ônibus correm em pistas exclusivas no centro da avenida e os carros ficam nas margens sem poder trafegar pela faixa preferencial. Se alguém quebrar a regra será multado imediatamente. 0 curioso, é ver a coisa funcionando nos horários de pico, os ônibus passam e os carros ficam, é como se fosse uma punição para quem não usa o transporte público. Um ônibus que antes gastava 40 minutos para ir do Makenzie à Faria Lima agora leva de 20 a 25 minutos. Para os carros, continua a mesma coisa.

$[10 \mathrm{~km} \times 1,2 \mathrm{hs} \times 20 \mathrm{r} \$][240,00 \mathrm{DT}]$

O engarrafamento é uma das formas de hospedagem mais freqüentes de uma metrópole como São Paulo. É uma hospedagem que combina o deslocamento com a duração modulado num desencontro coletivo. 0 deslocamento $[\mathrm{km}]$, uma distância relativamente pequena nestes casos, quando multiplicada pelo duração [horas] e pelo consumo [r\$] atingem valores acima da média. Exemplo: se eu tivesse optado por fazer todo 0 trajeto de táxi sem usar o metro e o ônibus a tarifa seria de [10km x 2hs x 48r\$] [960,0DT], 4 vezes mais.

\section{4:07, Congonhas, sala de embarque.}

É incrível o quanto as companhias aéreas sentem prazer em ter você como passageiro. A sala de embarque, que pode ser chamada sala de passagem, é uma seqüência de portões, cada um com um destino programado. Sintetizando, é um ambiente dentro do sistema urbano com várias portas. Numa destas vamos entrar e ao fim de uma caminhada proposta pelos comissários, após um período de espera assentado em desconfortáveis poltronas enfileiradas em um ambiente tubular, somos convidados novamente a caminhar e a sair por uma outra porta a muitos de quilômetros de onde isto tudo começou. É uma hospedagem de passagem.

$[0 \mathrm{~km} \times 0,1 \mathrm{hs} \times 14,7 \mathrm{r} \$][0,00 \mathrm{DT}]$

55 minutos, vôo, Gol 1706.

A duração de um vôo simultâneo a um grande deslocamento e um consumo alto acaba gerando uma tarifa muito alta. Mais uma vez surge a oportunidade de se fazer um 'amigo descartável'. Por opção leio um livro.

[570km x 1hs $\times 260.0 \mathrm{r} \$[148.200,00 \mathrm{DT}]$ 
Resolvi fazer uma caminhada até a Avenida Antônio Carlos Para pegar um ônibus. No trajeto fui trazendo a memória minhas últimas horas e tentei lembrar da fisionomia das pessoas com quem desencontrei. É incrível, faça este exercício também. Não tenho a menor idéia de quem me vendeu 0 bilhete do metrô, quem me serviu um café na padaria ou se o caixa do supermercado era homem ou mulher... nada. Realmente os desencontros são encontros para serem esquecidos.

$[1 \mathrm{~km} \times 0,2 \mathrm{hs} \times$ Or $\$[0,00 \mathrm{DT}]$

15:30, avenida Antônio Carlos, ônibus.

$[8 \mathrm{~km} \times 0,5 \mathrm{hs} \times 1,4 \mathrm{r} \$[5,60 \mathrm{DT}]$

16:20, supermercado.

Passo rapidamente pelo supermercado próximo de casa para comprar alguma coisa para comer.

$[0,2 \mathrm{~km} \times 0,3 \mathrm{hs} \times 35 \mathrm{r} \$][2,10 \mathrm{DT}]$

\section{6:58, casa, lanche.}

Ligo a televisão para assistir um pouco do noticiário. Saber o que acontece, consumir notícias do sistema urbano é essencial para se estabelecer uma memória coletiva de fatos que ninguém presenciou, mas que todos podem a qualquer momento utilizar numa conversa desencontrada ou num encontro sem assunto.

[0km $\times 2 \mathrm{hs} \times 15 \mathrm{r} \$][0,00 \mathrm{DT}]$

18:55, táxi, av. Afonso Pena.

Um taxista muito simpático puxa uma conversa. Aí podemos usar nossa memória coletiva para comentar e relembrar momentos que nunca presenciamos. Quando a memória coletiva não é o tema da conversa, assuntos particulares e específicos são abordados numa conversa que na maioria das vezes se torna desagradável ou inconveniente.

$[1,4 \mathrm{~km} \times 0,1 \mathrm{hs} \times 10 \mathrm{r} \$][1,4 \mathrm{DT}]$

19:30, ônibus, ida para Coronel Fabriciano.

É sempre o mesmo motorista e eu sei o nome dele pelo crachá com uma foto, uma foto do motorista, dele mesmo.

[254km x 3hs $\times 37 \mathrm{r} \$][28.194,00 \mathrm{DT}]$

\section{2:30, segunda, Coronel Fabriciano, terminal rodoviário.}

Fim de mais um deslocamento. Vou dormir um pouco mais, desta vez numa cama, num hotel. Amanhã tenho um encontro, vou trabalhar cedo. 
$[0 \mathrm{~km} \times 8 \mathrm{hs} \times 60 \mathrm{r} \$[0,00 \mathrm{DT}]$

Finalmente podemos chegar num valor aproximado para a hospedagem no sistema urbano segundo este modo de vida. Ressaltamos que cada modo de vida tem o seu valor. O valor sempre será individual e distinto. Seria impossível estabelecer uma tarifa padrão para qualquer grupo de indivíduos que habitam o sistema urbano. Os modos de vida são muito específicos. Para este relato, o valor da diária urbana seria tarifada em 655.477,63 DT com uma modulação de 25\% de encontros e $75 \%$ de desencontros.

\section{$3^{\text {a }}$ etapa:}

O vídeo 5305 fotos ilustra esta diária urbanaMM. O vídeo se encontra no DVD-Rom anexo à esta dissertação. 
2.3.2.5.

podscape $^{\mathrm{MM}}$

2.1. hipóteses de percepção, análise e critica do espaço - a paisagem material e a imaterial

2.1.1. análise dos ritmos do cotidiano (Lefebvre - Rhythmanalysis)

2.1.2. paisagem de eventos (Paul Virilio e Tschumi)

2.1.3. paisagem sonora

2.1.4. body violence (Tschumi - Architecture and Disjunction)

2.2. posições do observador/pesquisador; o corpo no urbano - o corpo na paisagem

2.2.1. procedimentos analíticos do corpo na paisagem; da patologia à imersão

2.2.2. a imersão corporal paisagística e seus procedimentos operativos

2.3. práticas: visualização e percepção do espaço comum

2.3.1. considerações gerais
2.3.1.1. a fotografia
2.3.1.2. o panorama
2.3.1.3. o Podcast e o iPod

2.3.2. os experimentos

2.3.2.1. o panorama temporário ${ }^{\mathrm{MM}}$ | panorama.temporario.org

2.3.2.2. paisagens temporárias ${ }^{\mathrm{MM}}$ | temporarylandscape.com

2.3.2.3. 15 minutos $^{\mathrm{MM}}$

2.3.2.4. diárias urbanas ${ }^{\mathrm{MM}}$

2.3.2.5. podscape $\mathrm{MM}^{\mathrm{MM}}$

2.3.2.6. MMSoundscapes ${ }^{M M}$ 
conceito

Podscape $^{\mathrm{MM}}$, que é a junção de podcast e soundscape, é um termo adotado neste trabalho para denominar uma proposta que busca expandir as possibilidades do podcast e do soundscape. Na verdade, o que temos aqui é uma proposta de prática espacial a partir dos recursos oferecidos pelo podcast e pelo soundscape. Estamos propondo uma experiência especulando as possibilidades de se criar e perceber novas paisagens urbanas por meio dos instrumentos em questão.

\section{a proposta}

Munido de um reprodutor de áudio portátil (um iPod@), por exemplo) e de um software gerenciador de podcats - RSS ${ }^{42}$ feeder (o iTunes(C) por exemplo) podemos experimentar 0 urbano por meio de paisagens sonoras.

construindo a minha paisagem sonora - um exemplo;

Meu computador conectado a internet me permite acessar os podcasts que são tecnicamente distribuídos pelos RSS feeders e gerenciados pelos RSS readers. Neste exemplo estarei usando como gerenciador de RSS feeders o iTunes@ e como unidade de áudio portátil o iPod@C.

A figura mostra a página inicial do iTunes Store onde posso procurar por podcasts que me interesso e assinar gratuitamente os que eu quiser. Os podcasts assinados são salvos no meu iTunes(c e imediatamente todos os programas disponíveis e sinopses são listados. 0 último episódio do programa assinado é carregado ${ }^{43}$ pelo software, caso deseje algum episódio anterior, posso solicitá-lo clicando no link correspondente.

42 RSS feeders são arquivos disponibilizados sites da internet capazes de gerenciar os arquivos de áudio e vídeo dos podcasts. Estes arquivos enviam comunicam aos softwares gerenciadores de podcasts a atualização de um programa, a disponibilização de um novo vídeo fazendo com que o software adquira os arquivos automaticamente do site.

${ }^{43}$ Carregado neste sentido é o mesmo que download, linguagem da internet originado do inglês. O processo "download" se dá quando um arquivo solicitado pelo usuário é transferido de um outro computador utilizando a rede mundial de computadores (a internet). Também é comum a expressão "baixar o arquivo". 


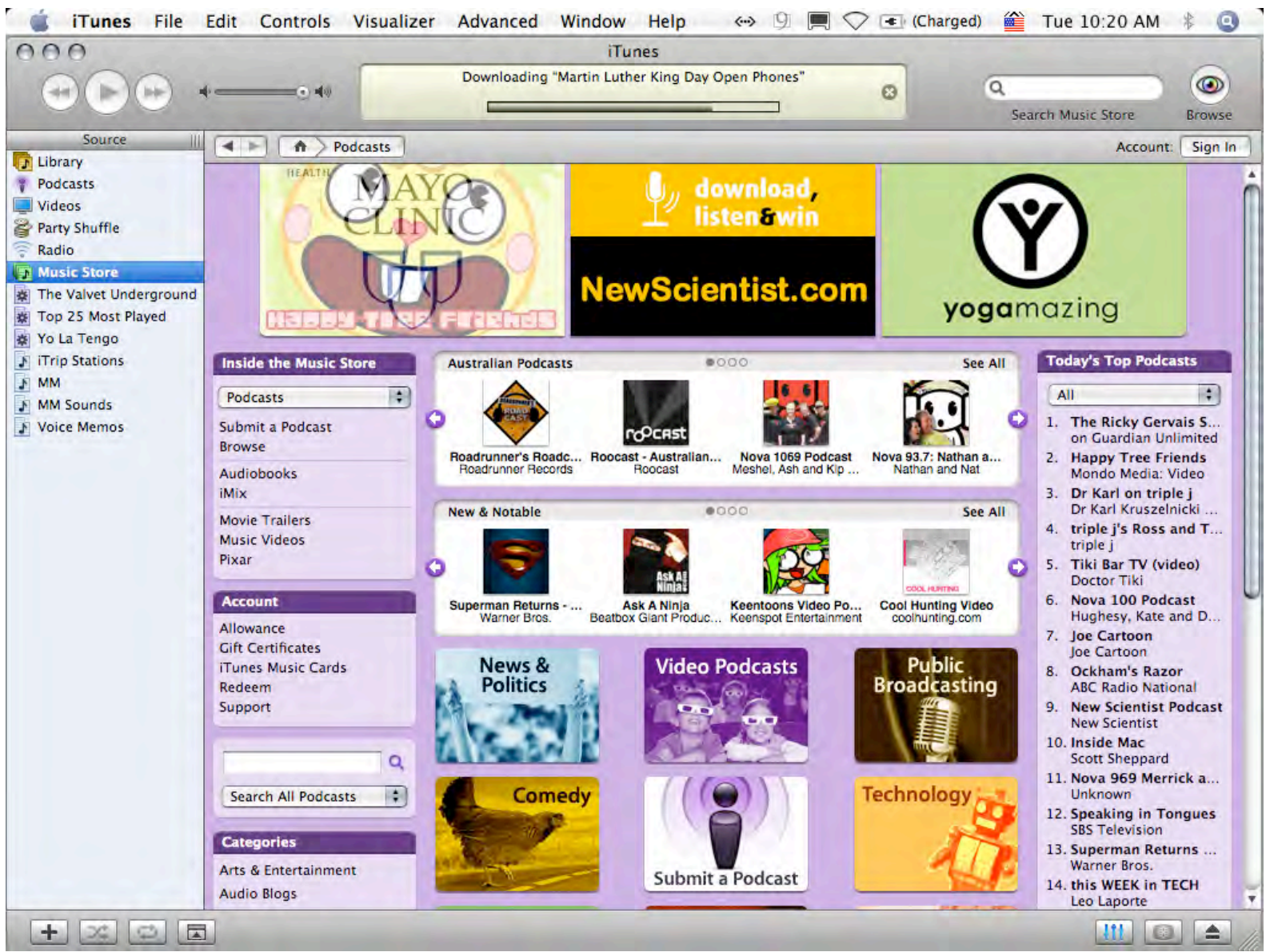

fig.8. página inicial do iTunes Store de distribuição, procura e divulgação de podcasts.

Todos os podcasts carregados no meu computador são automaticamente transferidos para a minha unidade portátil de som; 0 iPod@. A qualquer momento, saindo de casa, levo o meu aparelho e percorro os espaços comuns da cidade com uma paisagem sonora muito particular, construída pelas minhas escolhas. Vale lembrar que este processo tem alguma semelhança com o rádio, mas guarda algumas particularidades sutis com um resultado final instigante. Selecionar o que ouvir parece banal, mas quando analisado como modo de vida urbano e como componente de uma paisagem sonora urbana, o que era banal torna-se um incomodo condicionador sócio-espacial.

\section{Por exemplo:}

Supõe-se que presos no transito de São Paulo milhares de paulistanos escutam a CBN ${ }^{44}$, se estes milhares estivessem escutando os podcasts de uma unidade de som portátil conectado ao som do carro, ou uma unidade portátil de áudio, seriam milhares de programações completamente diferentes. Neste momento hipotético, podemos visualizar a uma sociedade cada vez mais fragmentada, seccionada em comunidades

$44 \mathrm{O}$ investimento em produção de notícias pelo rádio se transformou em prioridade para o Sistema Globo de Rádio, levando à criação da CBN - Central Brasileira de Notícias, nos moldes das melhores agências de notícias. A CBN é hoje a maior rede de emissoras all news, que transmite via satélite 24 horas de jornalismo. Criada em $1^{\circ}$ de outubro de 1991, a CBN está presente nas principais cidades e capitais como Rio de Janeiro, São Paulo, Belo Horizonte e Brasília. Com mais de 200 jornalistas pelo país, a rádio que toca notícia focaliza os principais assuntos nacionais e internacionais, com um estilo de programação próprio e exclusivo. fonte: http://radioclick.globo.com/cbn/ verificado a disponibilidade em 17/01/2006. 
formadas por identidades e construídas por preferências. Manuel Castells e Zygmunt Bauman respectivamente com seus livros O Poder da Identidade (CASTELLS, 1999) e Comunidade (BAUMAN, 2003) ${ }^{45}$ aprofundam esta questão. São espaços sonoros que se formam e se fundem criando relações que se superpõe às espacialidades criadas pelas imagens que compõe a paisagem urbana. A percepção espacial de cada indivíduo passa a ser única numa escala infinitamente maior do que já seria naturalmente (naturalmente devido aos fenômenos psíquicos da percepção). Se a visão e a audição são as fontes de percepção do corpo ao andar pela cidade, tendo uma das percepções (a auditiva) deslocada para uma outra paisagem, podemos dizer que estamos percebendo e participando da cidade parcialmente. Quem sabe poderíamos desenvolver um estudo para detectar qual a porcentagem de deslocamento corporal, ou percepção parcial que esta experiência nos traria? Esta hipótese nos sugere uma experiência oposta: percorrer a cidade, se possível, de olhos fechados, guiandose apenas pela sua paisagem auditiva. Os cegos fazem isto. Como o fazem? Sabemos que a paisagem sonora permite uma percepção espacial factível. Apesar desta paisagem não ser tema de projeto dos designers, dos arquitetos e dos planejadores, ela está presente e está pronta para condicionar o modo de vida urbano. 
construindo uma paisagem sonora portátil

○ iTunes@ não é a única forma de se procurar por podcasts, existem outros softwares similares além de sites de busca, algo como um Google para podcasts, é o caso do Podscope (http://www.podscope.com). A interface do Podscope é ilustrada nas figuras 2, 3 e 4 numa seqüência de busca.

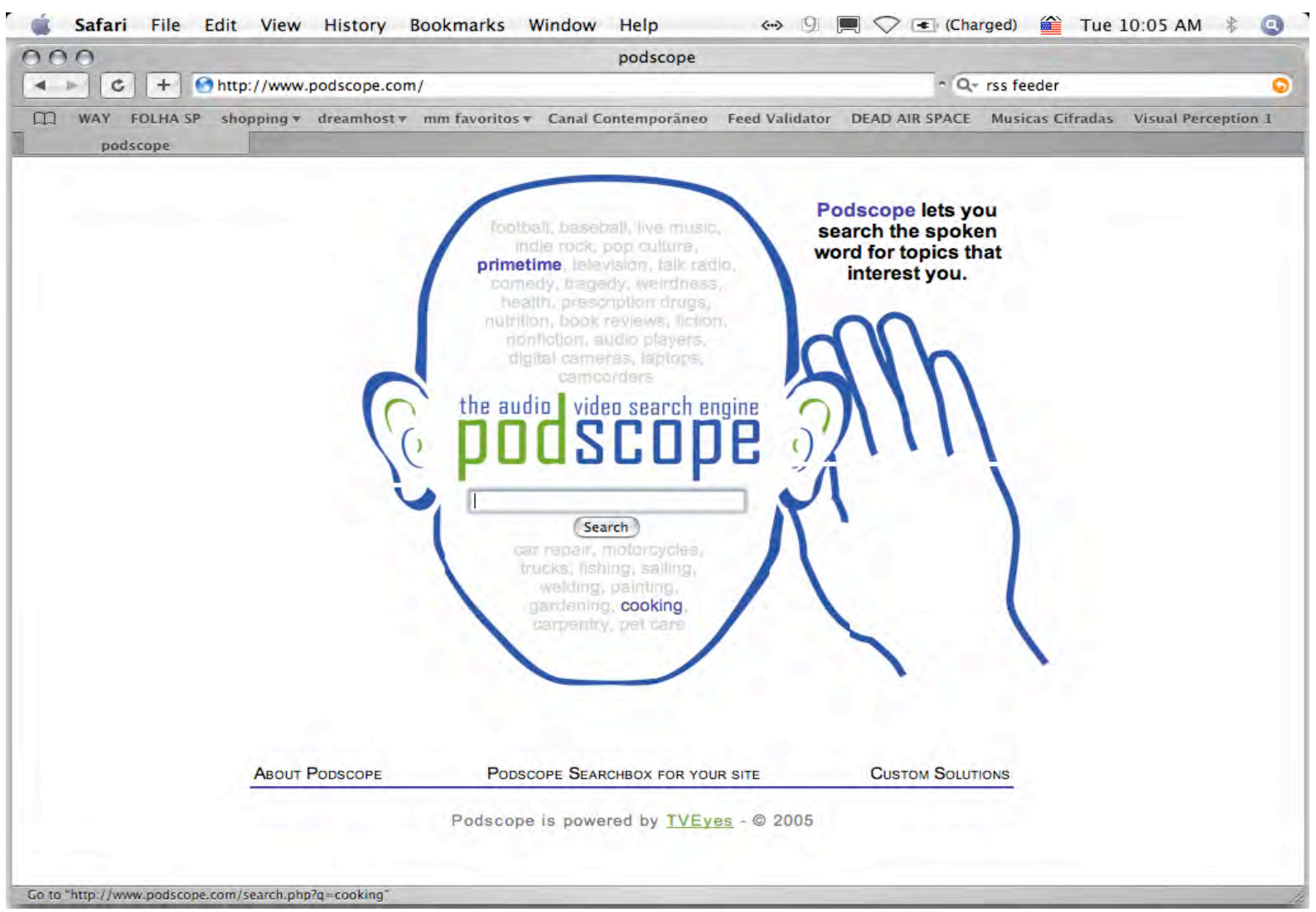

fig.9. página inicial do Podscope no dia 17/01/2006. 


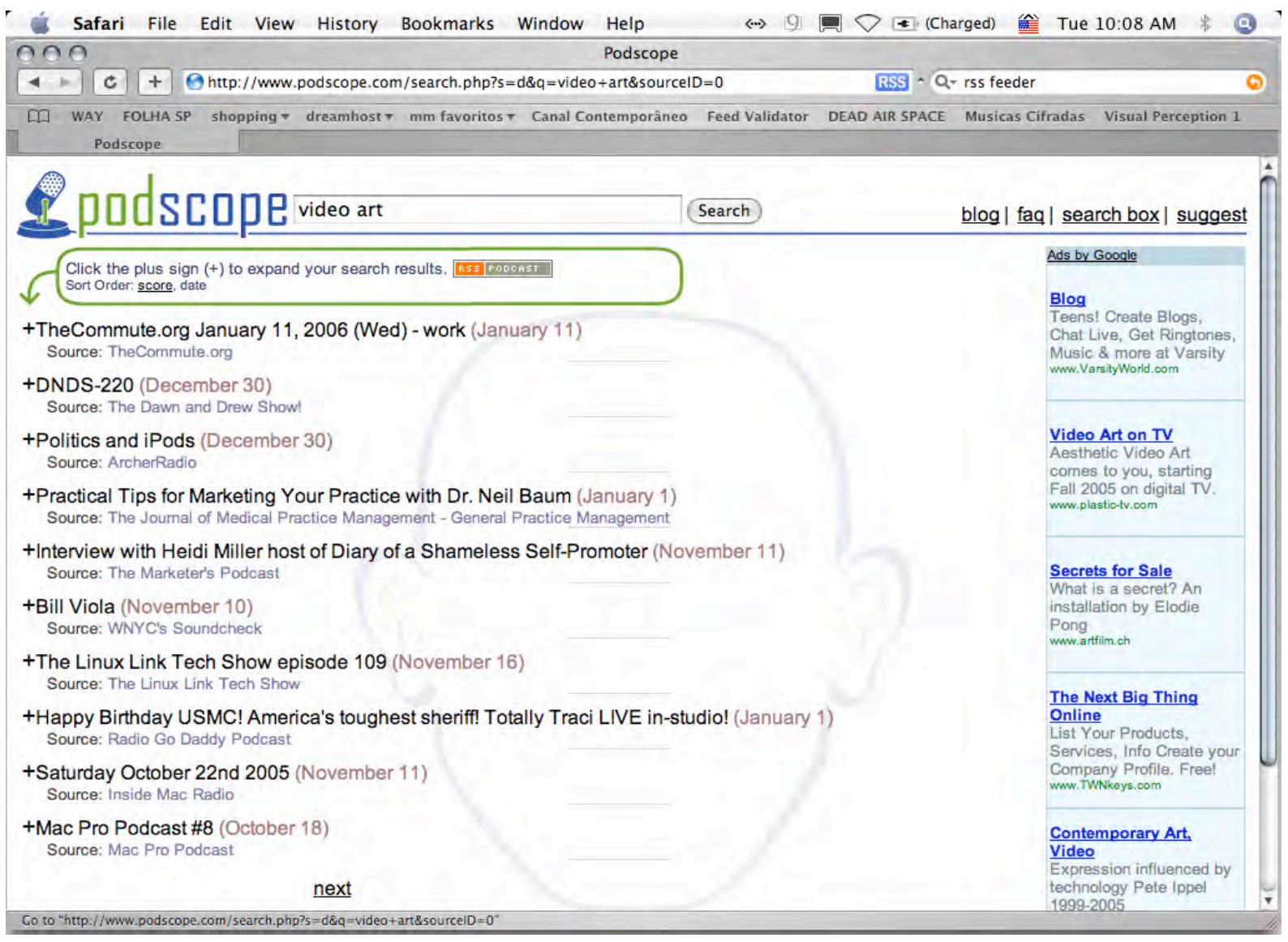

fig.10. busca por "vídeo art" no podscope e a lista das primeiras ocorrências.

Digitei a expressão vídeo art e procurei por algumas referências, dos resultados, o link Bill Viola me chamou a atenção. Resolvi seguir o link, selecionar o programa e acabei descobrindo o WNYC.org shows. Assinei alguns podcasts conforme a seqüência de imagens ilustra. 


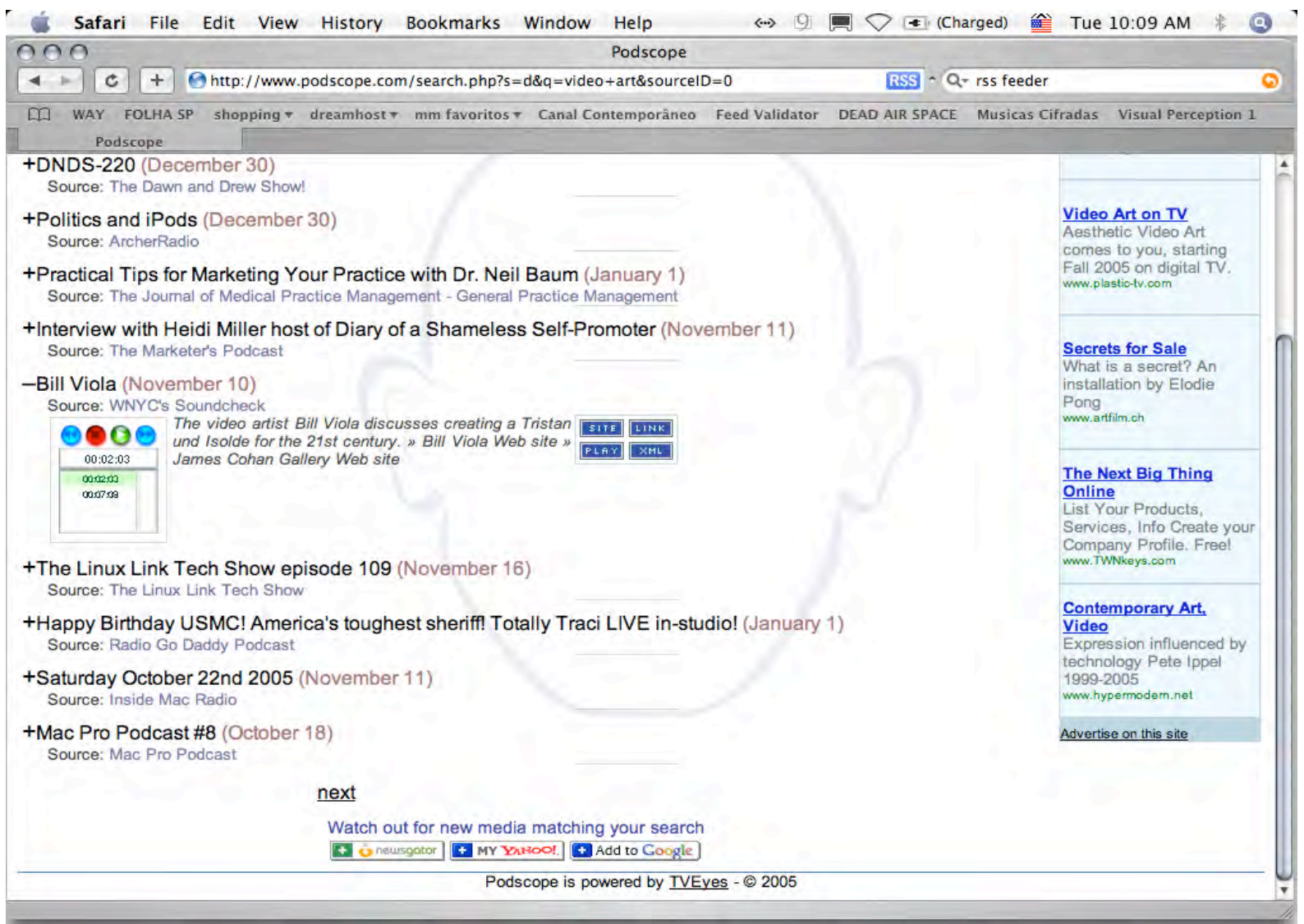

fig.11. link para o podcast referente ao trabalho de Bill Viola, publicado por soundcheck, programa da WNYC.org.

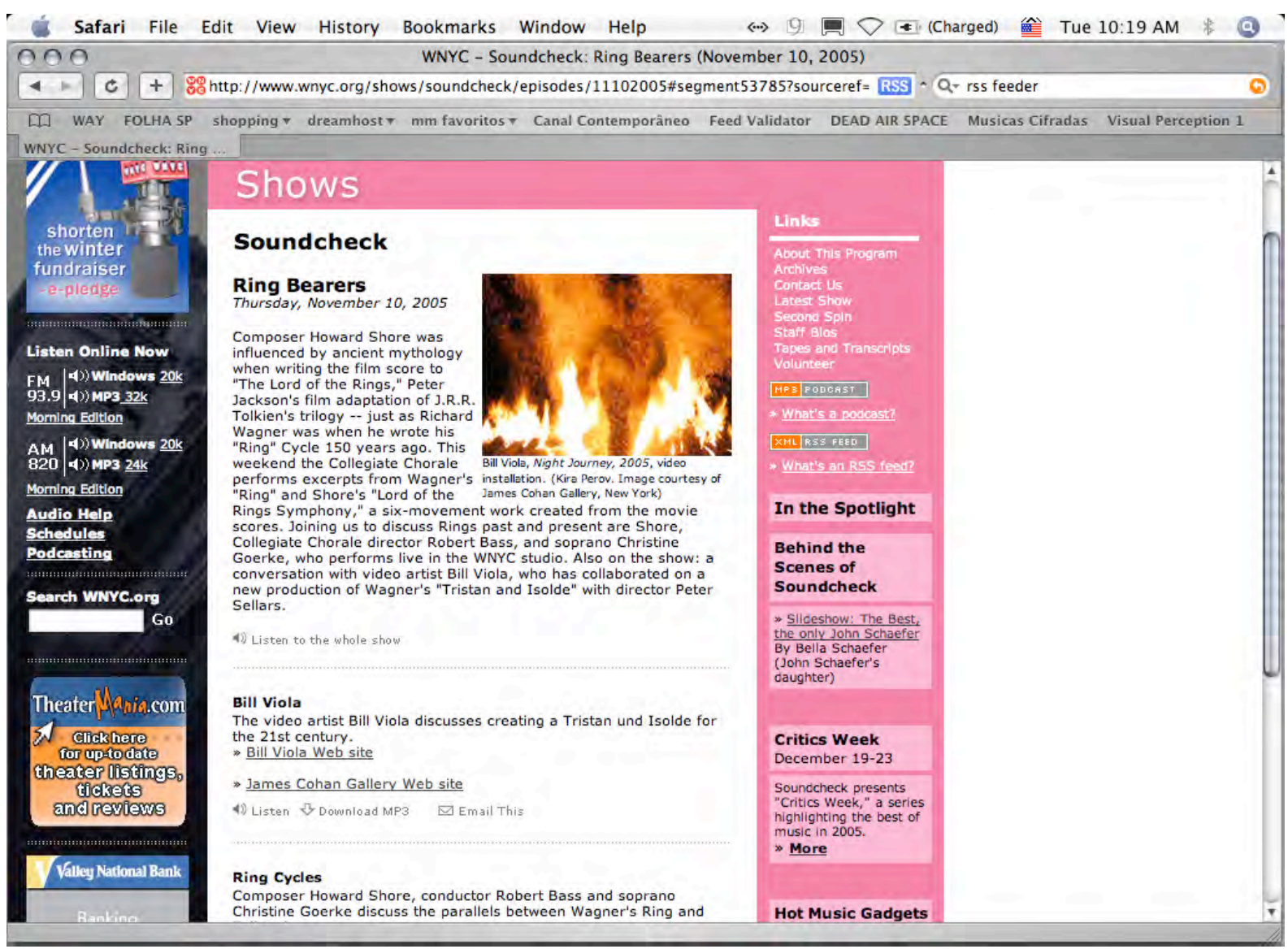

fig.12. sinopse do programa da WNYC.org sobre Bill Viola. 


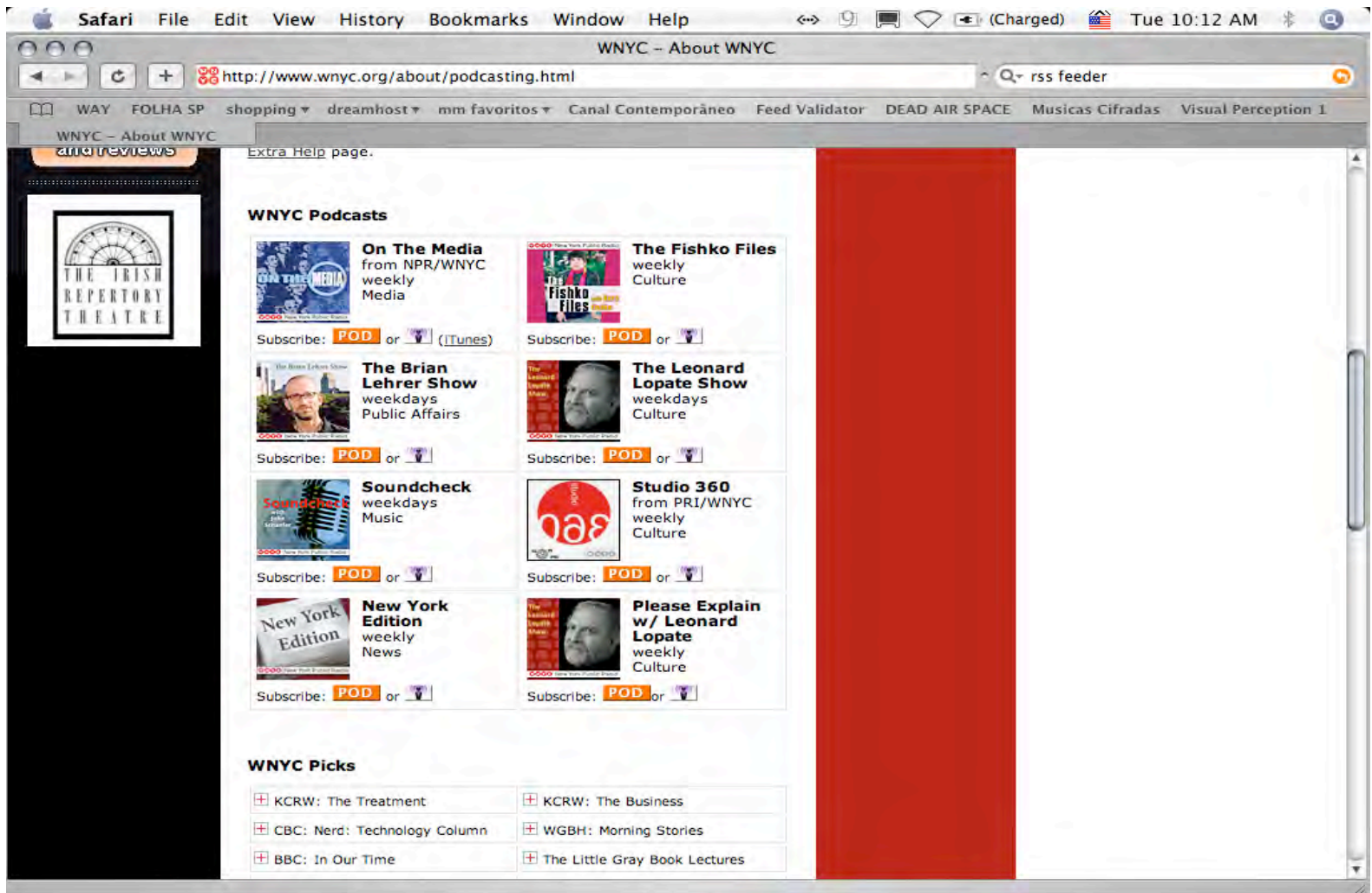

fig.13. outros programas da WNYC.org. Por curiosidade, segui o link do "The Brian Lehrer Show". O link me levou para o iTunes Store conforme mostra a figura 12 .

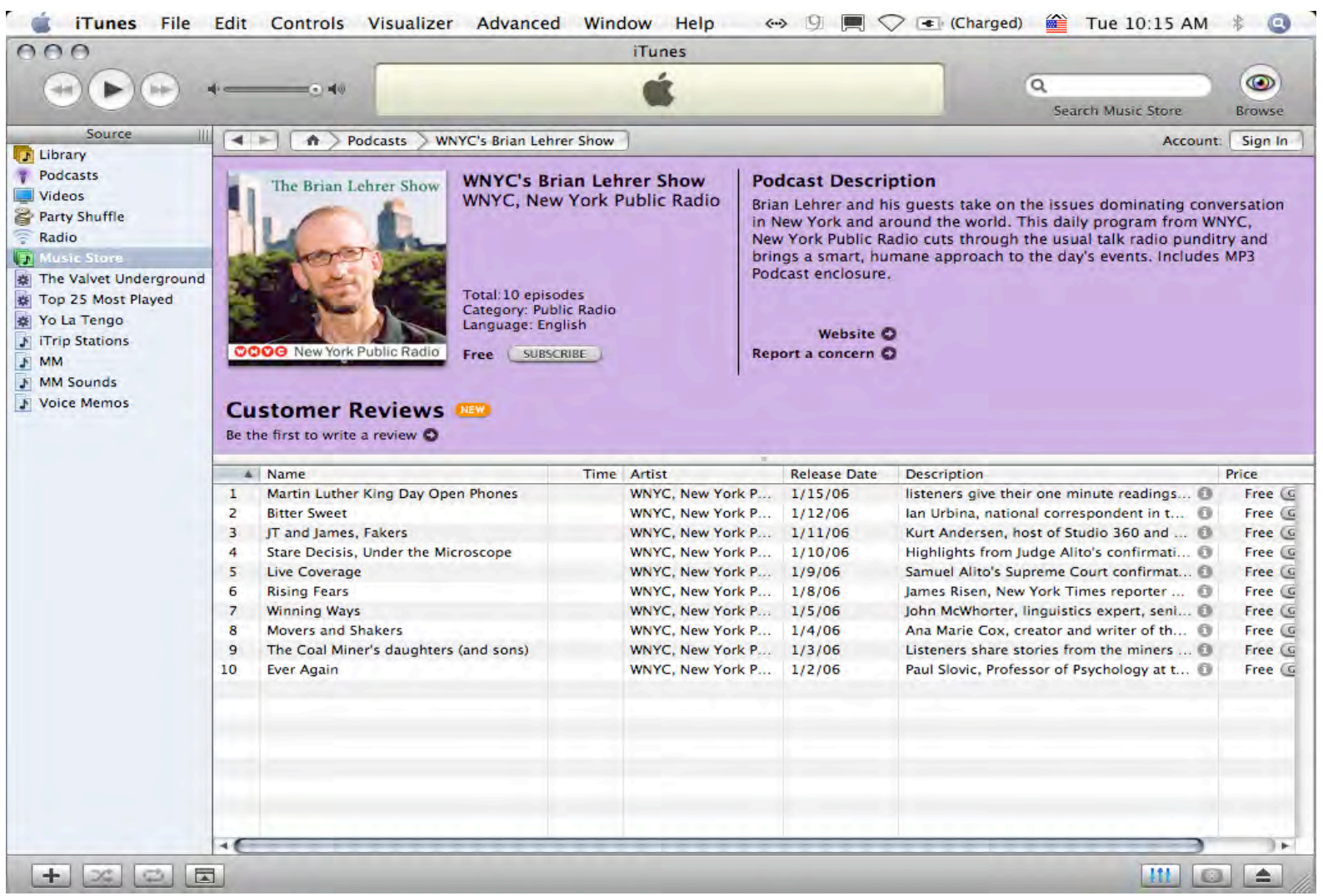

fig.14. WNYC.org Brian Lehrer Show na interface do iTunes $@$ para ler e gerenciar os RSS feeders do programa. 
Observe a lista com os programas já publicados, a direita seguem as informações; artista, data da publicação, e sinopse. Esta interface mostra apenas as primeiras palavras do texto, o texto completo pode ser visto clicando ícone circular cinza.

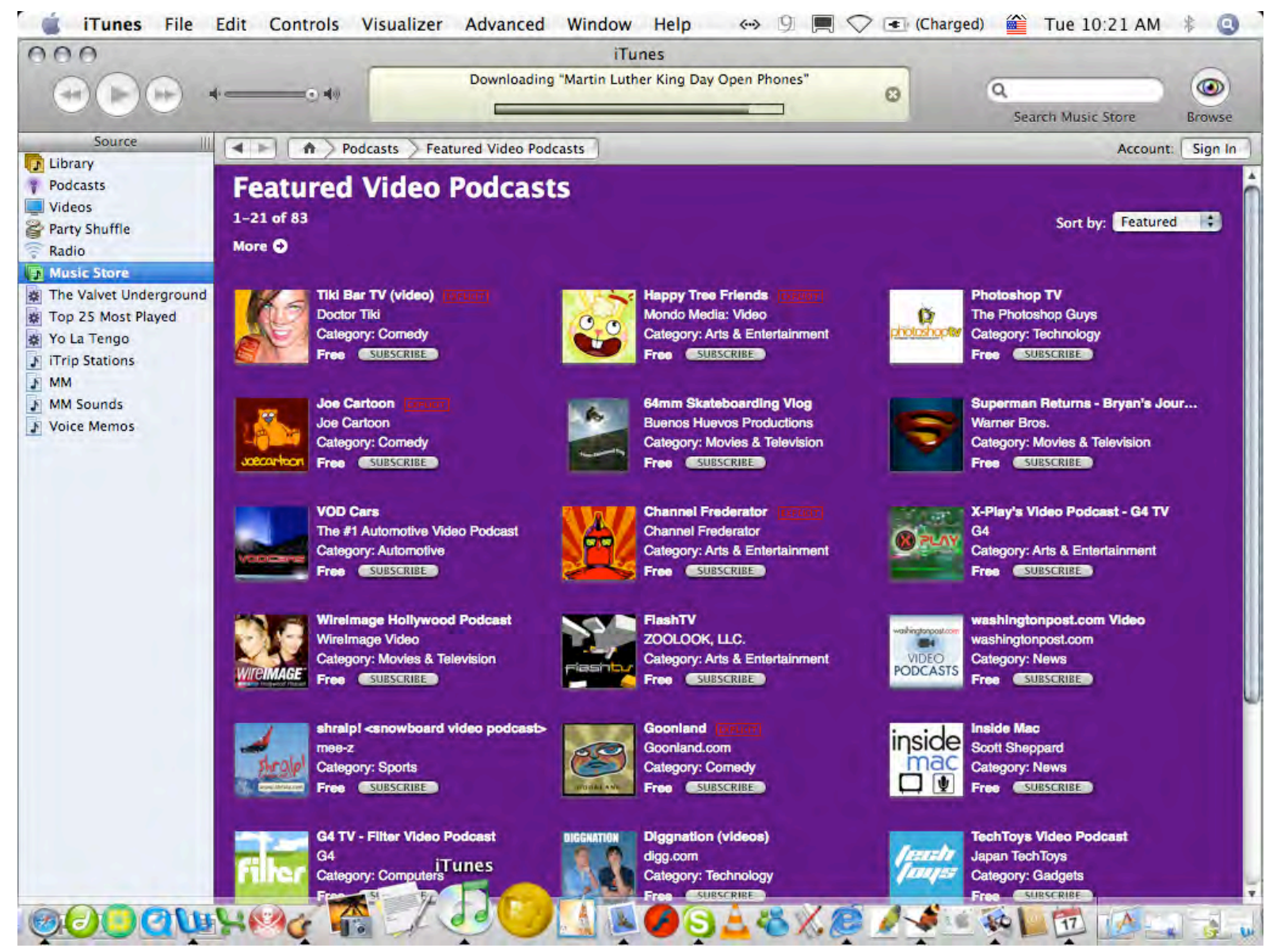

fig.15. lista de Vídeo Podcasts publicados pelo iTunes. 
O iTunes Store pode publicar podcasts e vídeo podcasts de seus assinantes. Se você quiser produzir o seu próprio programa de podcast, ou de vídeo podcast o iTunes poderá incluí-lo no seu diretório organizado por temas e assuntos diversos.

O vídeo podcast F.E.M. (Four Eyed Monsters) é um bom exemplo. Dois produtores independentes de cinema (Arlin Crumley e Susan Buice) publicam mensalmente um vídeo contando suas experiências de trabalho.

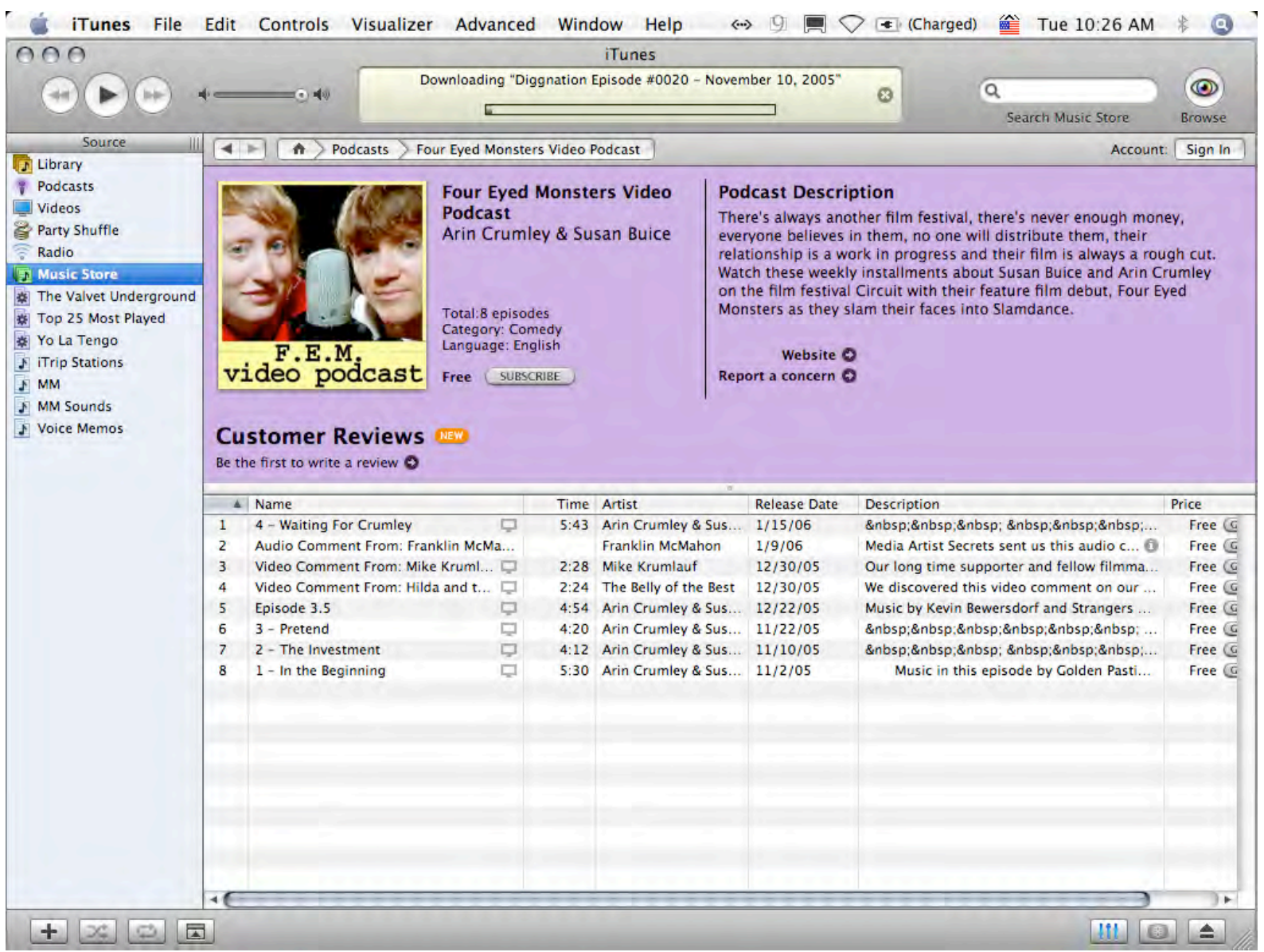

fig.16. Four Eyed Monster Video Podcast segundo publicação no iTunes Store em 17/01/2006. 


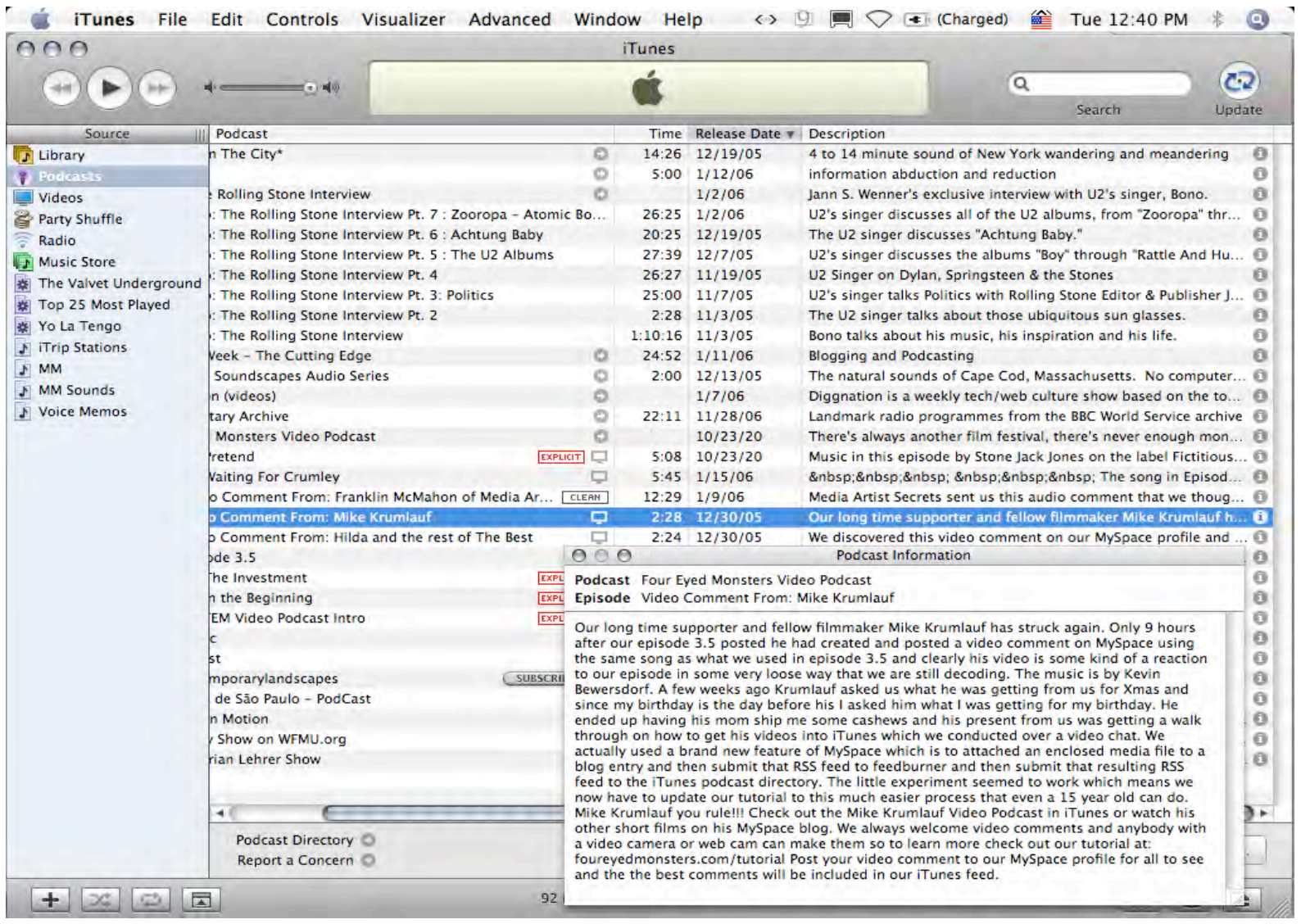

fig.17. sinopse do episódio selecionado.

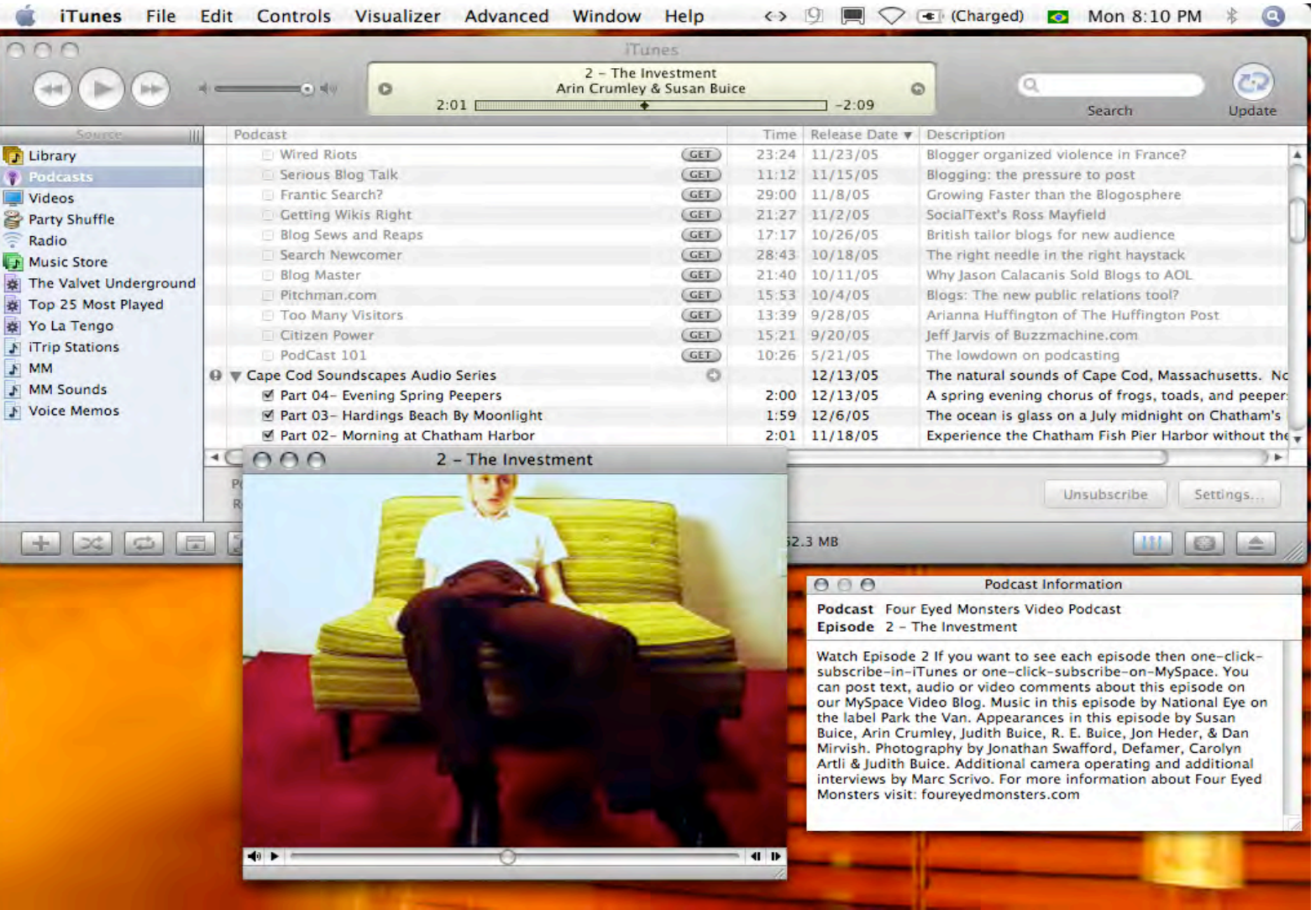

fig.18. Four Eyed Monsters, Video Podcast sendo exibido numa janela e a sinopse do programa. Interface do iTunes@ em 17/01/2006. 
Após a construção da minha paisagem sonora portátil, segundo minhas preferências, saio pelos espaços comuns da cidade pronto para uma outra experiência.

Complementando a proposta produzimos um vídeo que pudesse relacionar o espaço comum com 0 podscape. $O$ vídeo se encontra no DVD-Rom anexo a esta dissertação.

\section{uma crítica sobre a experiência}

É fato que a experiência proposta não é, e talvez nunca será uma experiência generalizada. Nada é certo, nada é impossível. Apesar da inserção de novas tecnologias como o telefone celular e a internet terem sido facilmente assimilados pelo nosso cotidiano não podemos fazer previsões semelhantes para outras tecnologias. Neste caso, podemos trabalhar com hipóteses que aparentemente inúteis num cenário de incertezas nos servem de algum suporte para transpor o terreno instável.

Uma hipótese possível, seria a de que uma grande parte da população construa seus próprios podscapes. Nesta hipótese algumas alterações no modo de vida e na própria paisagem produzida da cidade seriam percebidas. Alguns exemplos hipotéticos seriam; a redução no consumo de jornais e revistas, a redução da audiência dos programas de rádio e tv, já que os podcasts e o iPod Vídeo podem lidar muito bem com a distribuição e a visualização dos programas de TV. Numa hipótese muito radical, seria uma inversão completa da mídia e consequentemente uma outra forma de se construir uma memória coletiva para o espetáculo coletivo de Deborg. Automaticamente, outras formas de se distribuir mídias e de divulgar produtos vão surgir na paisagem. Outdoors, bancas de jornais e revistas, lojas de CD's e livrarias talvez não caberiam mais na paisagem das nossas cidades. Seriam em pouco tempo considerados uma forma obsoleta de mediação do espetáculo social.

Apesar da possibilidade de qualquer um produzir um podcast e se inserir no espaço da mídia não é certo que tal formato, a princípio democrático venha a ser mantido. Logo, as grandes empresas de mídia terão seu espaço retomado neste novo formato de distribuição ditando as regras do espetáculo. Voltando a nossa experiência urbana; se cada indivíduo entra num trem, no ônibus, no carro, numa sala de espera tendo uma experiência visual com este espaço somado a uma experiência auditiva fragmentada o resultado seria uma crescente dispersão das relações sociais no meio físico urbano e uma excessivo enlaçamento de relações sociais e formação de comunidades numa dimensão espacial cada vez menos material. Consequentemente a paisagem urbana vai ser gradualmente alterada em função destes novos eventos coletivos ainda estranhos que vêem substituindo gradualmente os eventos anteriores. A paisagem, enquanto resultante e condicionador dos eventos está para ser alterada num processo de mutação sutil que muitas vezes passa desapercebido sob nossos olhos. 
2.3.2.6.

MMSoundscapes ${ }^{\mathrm{MM}}$

2.1. hipóteses de percepção, análise e critica do espaço - a paisagem material e a imaterial 2.1.1. análise dos ritmos do cotidiano (Lefebvre - Rhythmanalysis)

2.1.2. paisagem de eventos (Paul Virilio e Tschumi)

2.1.3. paisagem sonora

2.1.4. body violence (Tschumi - Architecture and Disjunction)

2.2. posições do observador/pesquisador; o corpo no urbano - o corpo na paisagem

2.2.1. procedimentos analíticos do corpo na paisagem; da patologia à imersão

2.2.2. a imersão corporal paisagística e seus procedimentos operativos

2.3. práticas: visualização e percepção do espaço comum

2.3.1. considerações gerais
2.3.1.1. a fotografia
2.3.1.2. o panorama
2.3.1.3. o Podcast e o iPod

2.3.2. os experimentos

2.3.2.1. o panorama temporário ${ }^{\mathrm{MM}}$ | panorama.temporario.org

2.3.2.2. paisagens temporárias ${ }^{\mathrm{MM}}$ | temporarylandscape.com

2.3.2.3. 15 minutos $^{\mathrm{MM}}$

2.3.2.4. diárias urbanas ${ }^{\mathrm{MM}}$

2.3.2.5. podscape $^{\mathrm{MM}}$

2.3.2.6. MMSoundscapes ${ }^{\mathrm{MM}}$ 
MMSoundscapes ${ }^{\mathrm{MM}}$ é um multimídia que gerencia e manipula a reprodução de registros sonoros de ambientes urbanos. Este experimento sobre a paisagem sonora de situações urbanas é explorado sob duas formas com os seguintes títulos;

"...da minha varanda" e

"[re]construção de paisagens sonoras"

"...da minha varanda"

"...da minha varanda" é uma coleção de registros sonoros feitos a partir da varanda do meu apartamento. Os registros foram feitos em diversos horários do dia ao longo de uma semana. O objetivo aqui é ter uma coleção de registros que nos permita perceber o cadeamento rítmico do cotidiano do meu bairro. São registros do espaço com potencialidades distintas e ainda pouco exploradas. Assim como fotografia e o vídeo nos permitem apreender o espaço através da sua paisagem visual, o registro sonoro nos permite apreender 0 espaço através da sua paisagem sonora. A paisagem sonora também é um registro temporário do espaço. Os registros sonoros são recortes temporários do espaço. Surpreendentemente, ao analisar e comparar os recortes temporários - registros feitos em outro dia/outro horário - pode-se perceber uma série de ritmos do cotidiano que naturalmente se passavam desapercebidos.

"[re]construção de paisagens sonoras"

Como o próprio nome indica, este multimídia permite a construção (ou talvez a reconstrução) de uma paisagem sonora. Como a construção é composta por recortes temporários do espaço, daí a sugestão do ato de re-construir uma paisagem. Trata-se de uma colagem de sons que podem ser ativados e controlando sua intensidade (volume) e posição (ouvido esquerdo/direito) podemos construir um ambiente sonoro - uma paisagem sonora. Este experimento sugere que; assim como é possível ao arquiteto e ao designer manipular as imagens e os recortes temporários da paisagem visual urbana, o mesmo é possível à paisagem sonora urbana.

Ambos experimentos estabelecem um diálogo com o texto Análise de Ritmos de Henri Lefebvre (Rhythmanalysis, 2004), especialmente com o texto Seen From My Window onde Lefebvre permanece 24hs observando, memorizando e anotando tudo o que percebia, escutava e via num cruzamento de Paris a partir da janela do seu apartamento. 
conclusão 


\section{fluxo de idéias}

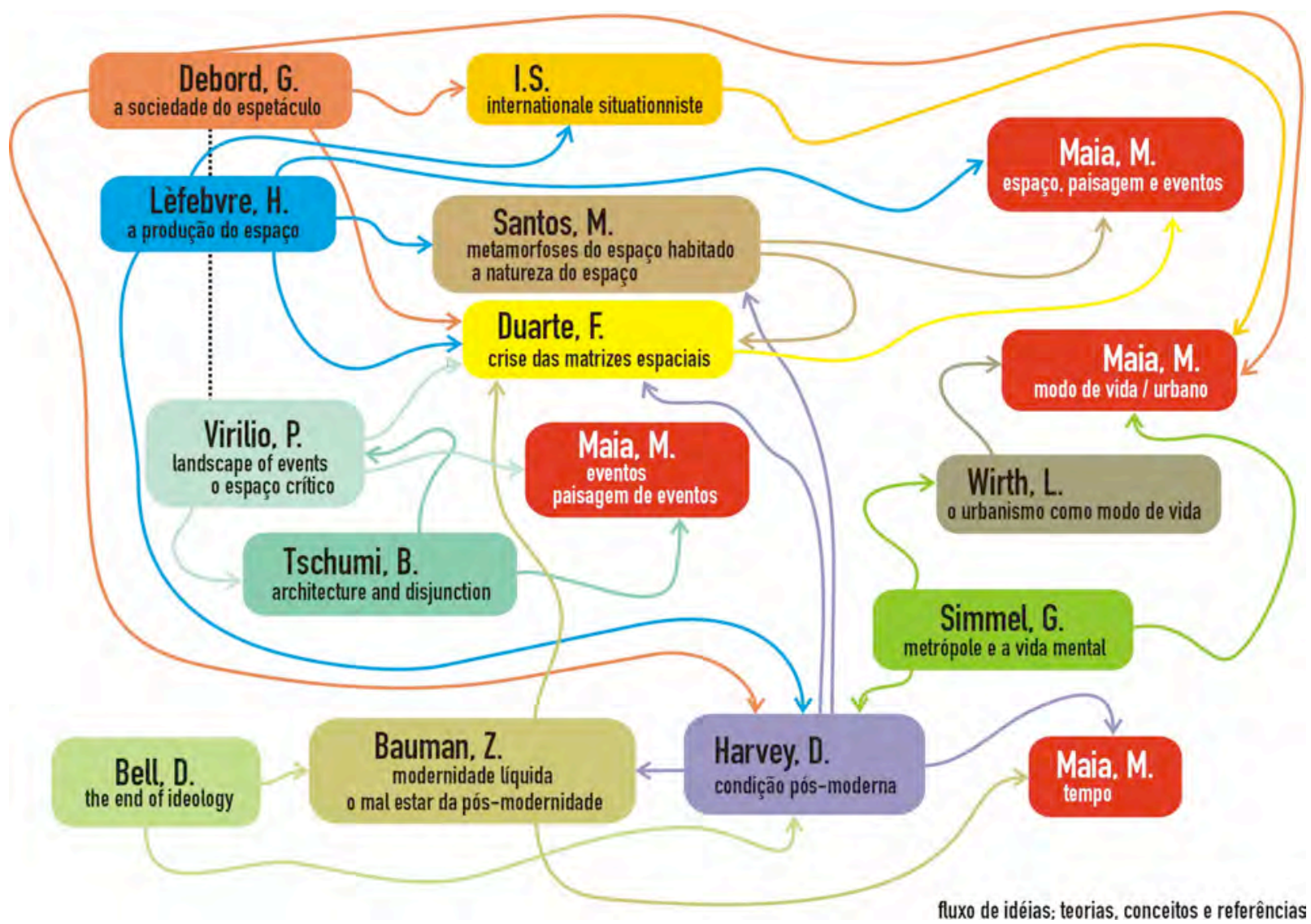

fig.19. fluxo de idéias.

O fluxo de idéias ilustrado pelo diagrama acima (ver. fig. 1). Trata-se de um inter-relacionamento das idéias da dissertação passando por diversos autores. Cada autor é apresentado no diagrama e associado a uma cor. Abaixo do nome do autor é listado o título da(s) obra(s) de referência. As setas que partem de um determinado autor e apontam para outro autor indicam um fluxo de idéias, conceitos e/ou conteúdos que são identificados e referenciados pelos próprios autores. Deborg, por exemplo é citado em bibliografia e é referência para Harvey e Duarte, mas também possui uma conexão com Lèfebvre e Virilio que não é citado em bibliografia mas é relatado em entrevistas e/ou outros relatos representado pela linha tracejada que liga os três autores.

O fluxo de idéias convergem para os conceitos e/ou termos desenvolvidos ao longo deste trabalho listados:

- tempo

- espaço, paisagem e eventos

- eventos (paisagem de eventos)

- modo de vida (o urbano) 
O tempo é uma convergência das idéias de Harvey e Bauman. Entretanto é importante destacar, enquanto contraponto a estas idéias, Lipovetsky com o texto Os Tempos Hipermodernos (2004) e Tati com 0 filme Playtime (1967).

Espaço, paisagem e eventos é uma contribuição fundamental para a discussão estabelecida aqui que foi introduzida por Lèfebvre e instrumentalizado por Santos.

Eventos e paisagem de eventos é um termo de Virilio que é amplamente desenvolvido, discutido e aplicado à arquitetura por Tschumi. Estes conceitos complementam a dinâmica da produção sócio espacial proposta por Lèfebvre e instrumentalizado por Santos intensificando a conexão com 0 urbano e com a arquitetura na questão espacial, principalmente nas suas dinâmicas temporárias.

Modo de vida, o urbano é um conceito que parte de Simmel com o texto "A Metrópole e a Vida Mental" e passa por Wirth no texto "O Urbanismo como Modo de Vida". A associação das idéias destes textos com as idéias de Lèfebvre e Debord via Internacional Situacionista constroem o conceito de urbano, dito modo de vida, discutido amplamente neste trabalho. 
rebatimentos

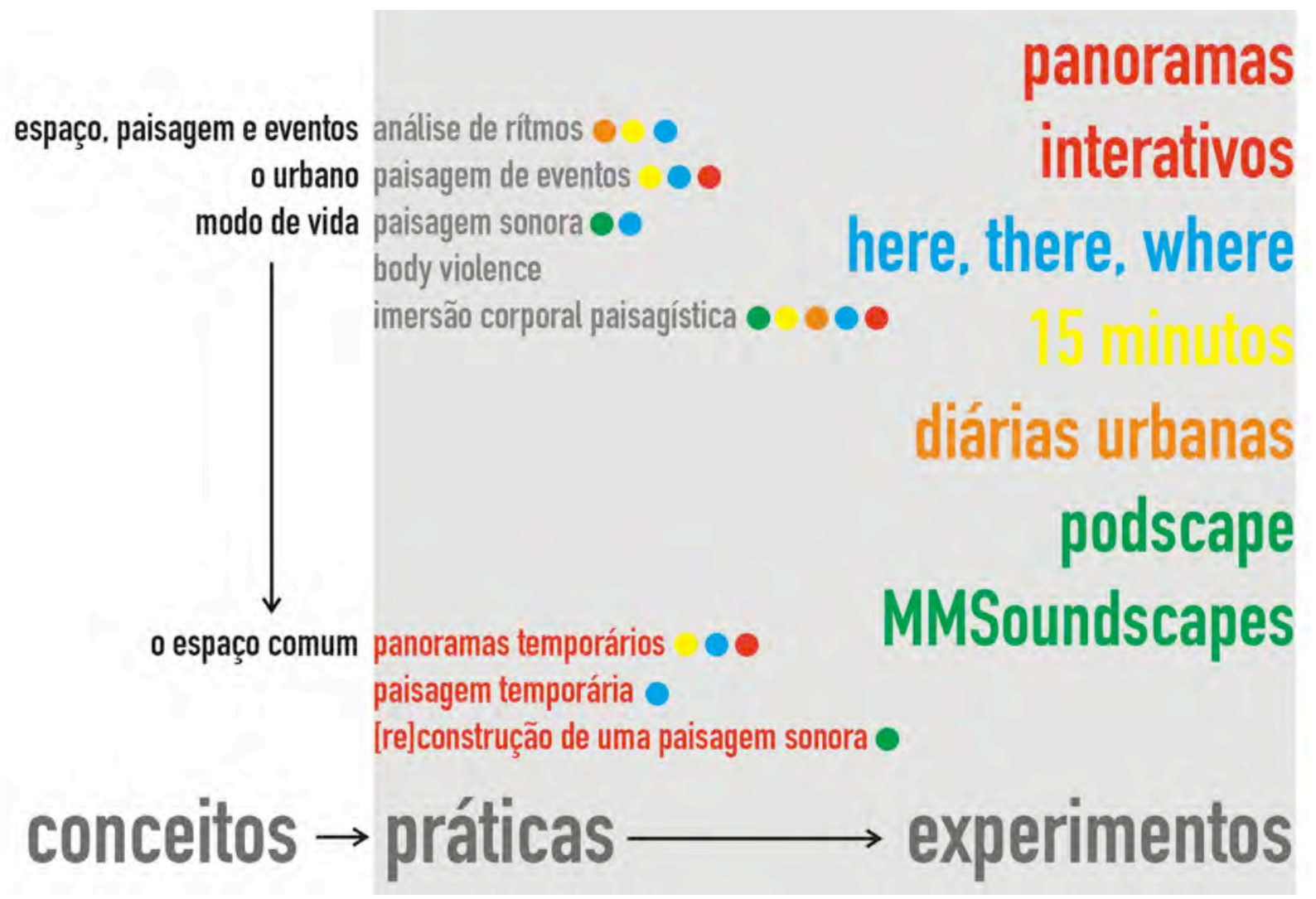

fig.20. rebatimentos.

O diagrama apresentado acima (ver fig. 02) ilustra o rebatimento dos conceitos abordados durante 0 trabalho nos experimentos. Na parte superior do quadro são apresentados conceitos e referências de outros autores. Na parte inferior, o conceito síntese (o espaço comum) e os produtos desenvolvidos ao longo do trabalho (em vermelho). Os círculos coloridos marcam o rebatimento dos conceitos e dos produtos nos experimentos apresentados. Os experimentos podem ser encontrados no DVD-Rom em anexo e na internet no endereço http://comum.temporario.org. 


\section{conclusões temporárias sobre o espaço comum}

A arquitetura (inclui-se aqui o urbanismo) e o design são disciplinas que essencialmente lidam com 0 espaço. São produtos culturais que são condicionados e que condicionam os espaços urbanos. Pensar em arquitetura e design sem pensar no urbano seria o mesmo que pensar numa arquitetura e num design para ser contemplado e nunca apropriado. O produtor cultural (o arquiteto) que projeta um edifício dentro dos limites de um lote e estabelece uma rígida relação público e privada, quer seja pelo traço (desenho) acompanhado por muros e dispositivos de segurança que pretensiosamente declaram uma independência do urbano sem a menor noção do seu papel urbano. A intervenção arquitetônica é uma intervenção urbana em potencial.

O design também é urbano, talvez até mais do que se tem discutido. A televisão, o automóvel, o computador pessoal, a internet (web design), o telefone celular, o iPod, etc., condicionam os modos de vida e sutilmente alteram o tempo e consequentemente o espaço urbano.

O tempo por sua vez é uma dimensão espacial que tem se tornado cada vez mais forte na cultura contemporânea. Sem desconsiderar a dimensão geométrica do espaço e sem negar sua condição essencial à vida urbana, entretanto, percebe-se que historicamente as dimensões geométricas que era o centro da cultura estão sendo superadas pela dimensão temporal. Numa breve passagem sobre a história, as propriedades materiais, especificamente a terra e a arquitetura eram o centro da cultura até a revolução industrial. A nobreza e a igreja de posse de terras e arquiteturas notáveis (templos, palácios e fortalezas) eram a maior referência cultural e se em algum momento deste período destacarmos o surgimento de uma cultura urbana, esta estaria vinculada a eles.

Historicamente, a propriedade material, a terra, o edifício, a arquitetura, sempre foram conquistas humanas centradas ou que pelo menos orbitavam nas relações culturais da sociedade. Com a revolução industrial, o foco das relações culturais foi sendo transferido das propriedades para os bens de produção. Com 0 surgimento da sociedade de massas, a tecnologia, que transformou os processos de produção, passou a superar as propriedades. Saber fazer, saber transformar e como produzir e atingir as massas passou a ser mais importante do que a propriedade. Num curto espaço de tempo, este saber tecnológico aliado ao tempo e aos sistemas de informação passaram a valer tanto quanto ou mais que a propriedade material. Destacamos por exemplo a Apple, o Google, e a Microsoft (citando alguns aleatoriamente). São propriedades tecnológicas que estão relacionadas à dimensão temporal do espaço. Praticamente, ao venderem sistemas de informação que condicionam a vida urbana, estes são detentores de uma dimensão espacial urbana que toma cada vez mais força na cultura contemporânea.

Por outro lado a dimensão material também ganha força, mas ganha força não do ponto de vista de propriedade, mas do ponto de vista coletivo. O material, ou os recursos materiais, as fontes de energia do nosso planeta são preocupações que dizem respeito à uma dimensão cada vez mais urbana. O consumo de carvão na 
Rússia, na Europa e na América do Norte já anuncia problemas climáticos para Ásia. Ou seja, o modo de vida da Rússia tende a influenciar o modo de vida de outros países. Além do aquecimento global temos a questão da água, do lixo e dos resíduos tóxicos. A cultura contemporânea caminha num sentido de intenso compartilhamento dos recursos materiais e uma homogeneização do tempo e da cultura (a globalização). Logo as dimensões materiais e temporais nunca foram tão requisitados à um interesse comum quanto hoje. $\mathrm{O}$ urbano, que é a inter-relação de indivíduos compartilhando o mesmo espaço, é uma inter-relação de indivíduos compartilhando os mesmos tempos e os mesmos recursos naturais numa escala mundial. 0 espaço comum é uma tendência irreversível.

O design está mais atento à estas questões. Quer sejam às questões da dimensão temporal no urbano (o iPod), quer sejam das questões da gestão dos recursos materiais (o eco design). A Arquitetura, por outro lado, carrega uma cisma espacial idealizada pelo movimento moderno. Um espaço austero, projetado preferencialmente para não ser habitado. Uma cisma relacionado à paisagens eternas, rígidas e monumentais que são completamente incompatíveis com as dinâmicas espaciais atuais. As paisagens marcantes do século 21 são eventuais, instantâneas e dinâmicas. Seus monumentos são eventuais. 0 atentado de 11 de setembro é uma referência para estas questões.

Entretanto as correntes culturais não apontam para esta tendência. A segregação urbana explode em escalas mundiais. $O$ que antes era uma exclusividade dos países em desenvolvimento, hoje atinge os Estados Unidos e a Europa. Entretanto, vale lembrar que a segregação urbana é viabilizada por fortes instrumentos de artificialização ambiental. São ambientes artificialmente construídos que impedem a interrelação natural de um ambiente urbano. São ambientes semelhantes às estações espaciais e/ou submarinas que artificialmente criam um ambiente independente do meio ao qual este se coloca. Sabemos que o custo ambiental é alto e insustentável. São ambientes anti-urbanos. São culturas anti-urbanas. Se 0 urbano é uma cultura responsável pela produção e gestão do bem estar das nossas cidades. Assim como a ecologia é responsável pela produção e reprodução da vida numa reserva ambiental, o urbano é responsável pela produção e reprodução dos modos de vida e da qualidade de vida urbano-ambiental das nossas cidades. O surgimento de uma cultura anti-urbana pode ser insustentável e pode gerar prejuízos irreversíveis à gestão de recursos espaciais, quer sejam eles temporais ou materiais.

Este trabalho indiretamente buscou ampliar a noção de espaço abrangido por elas. Entretanto, este trabalho não deve ser considerado como uma pesquisa acerca do espaço da arquitetura e do design na sociedade e na cultura contemporânea. Antes uma analise do espaço urbano no qual a arquitetura e o design podem se inserir. É portanto, aqui também, uma experiência pois busca de alguma forma colocar uma sensibilidade para as questões espaciais e urbanas que dizem respeito (ou pelo menos deveriam) à arquitetura e ao design. 
Por meio de práticas sensíveis uma outra discussão é lançada aqui. A representação como meio de visualizar, perceber e conceber espaços na arquitetura caminhou desde o renascimento por meios ideológicos onde 0 homem, e principalmente o corpo do homem e o tempo do homem não importavam. 0 posicionamento era científico, o observador sempre distante, assim era a perspectiva e os métodos cartesianos de representação. Aos poucos uma alienação espacial foi tomando conta do fazer arquitetônico. Uma distância/alienação tanto dos processos sociais, espaciais e culturais urbanos quanto dos processo produtivos da própria arquitetura. A tecnologia passou a ser conferida ao engenheiro. Os processos construtivos e a técnica impulsionados pela indústria trouxeram a figura do designer um pouco mais atento aos processos espaciais de produção. Entretanto o designer, ainda estava um pouco distante dos processos espaciais urbanos. A arquitetura ao fim do século XIX atinge 0 ápice da alienação espacial ao conferir sobre seus projetos estudos que dizem respeito apenas à proporção, distribuição e adequação de desenhos bi-dimensionais à suas composições neo-clássicas. Aqui a arquitetura perdeu completamente a dimensão espacial e se tornou apenas uma representação. 0 movimento modernista no início do século 20 resgatou o espaço e o espaço de produção, entretanto a contribuição da arquitetura ao urbano estava impregnado de ideologias. 0 distanciamento arquitetura e prática urbana era tanto que foi necessário instaurar 0 urbanismo enquanto disciplina para um ideal urbano, ou uma disciplina para se criar modos de vida e instituir um cotidiano projetado. Era quase que uma disciplina que se propunha a conceber modos de vida para uma sociedade ou projetos de comportamento social. A alienação aqui não era espacial, era urbana. Era uma alienação social. A sociedade e os modos de vida cotidianos estavam distantes demais, há muito abandonados pelos modernos, por desconhecimento, ou despercebimento dos modernistas precisavam ser substituídos ou reinventados por outros idealizados.

\section{CAU; experiências educacionais de sensibilização}

O DVD-Rom anexo contém uma coletânea de animações elaborada por alunos do Curso de Arquitetura e Urbanismo do UnilesteMG. São animações desenvolvidas na disciplina Animação e Modelagem (http://www.rimusnoc.com/cau/aem) que leciono juntamente com o prof. Alexandre Campos. Esta disciplina procura por meio de animações, trazer questões referentes às possibilidades de perceber, conceber e representar os espaços. É nosso objetivo, enquanto educadores, desenvolver uma sensibilidade sócio-espacialurbana nos alunos. Trabalhando com animações, panoramas, música e registros sonoros a disciplina explora 0 potencial da linguagem digital ampliando o instrumental conceptivo e representativo do estudante. 


\section{a imaterialidade da paisagem instantânea}

Este trabalho procurou por práticas sensíveis, ou seja, instrumentos de visualização, percepção e potencialmente de concepção de espaços. São práticas que ampliam a possibilidade do arquiteto de do designer lidar principalmente com as dimensões temporárias do espaço. É notável que os instrumentos que lidam com a dimensão material da arquitetura foram e ainda são amplamente desenvolvidos. Entretanto é possível observar uma certa incapacidade da arquitetura em desenvolver instrumentos capazes de lidar com as dimensões temporárias do espaço. Logo, se o arquiteto pretende atuar na esfera urbana, o tempo não pode ser desprezado. 0 tempo passa a ser uma dimensão tão fundamental quanto a dimensão física. 0 tempo, parte da dimensão espacial urbana, traz para o projeto as variáveis culturais, econômicas, sociais, ecos-ambientais, políticas, etc. A geometria, que também é parte da dimensão espacial urbana, traz para o projeto as variáveis climáticas (insolação e ventilação), as técnicas construtivas, e a própria ergonomia dos espaços, esta, fundamentalmente apoiado nos eventos que geram a forma e que por sua vez é tempo novamente. Numa visão mais abrangente, 0 tempo sempre condicionou os espaços e gerou formas. 0 tempo através dos eventos formou a matéria. $O$ que se observa hoje é que a formação da matéria dada pelo tempo tem acontecido numa velocidade crescente. Em alguns casos, como a internet, espaços são criados e eventos acontecem sem conformar matéria, portanto sem criar paisagens. São instantâneos. Que a internet é espaço não há dúvida pois neste espaço ocorrem eventos, encontros, trocas, etc. Entretanto, qual a paisagem da internet? A internet possui uma paisagem? $\mathrm{O}$ artista italiano Marco Cadiolit6 possui um projeto que também levanta esta questão.

${ }^{46}$ Internet Landscape is a project of photo reportage from the world of the Net.

On line sinse 2003 it looks at the growing cyberspace landscape, at the first collective environments, at the presence of human and robots between the interfaces on the screen. 


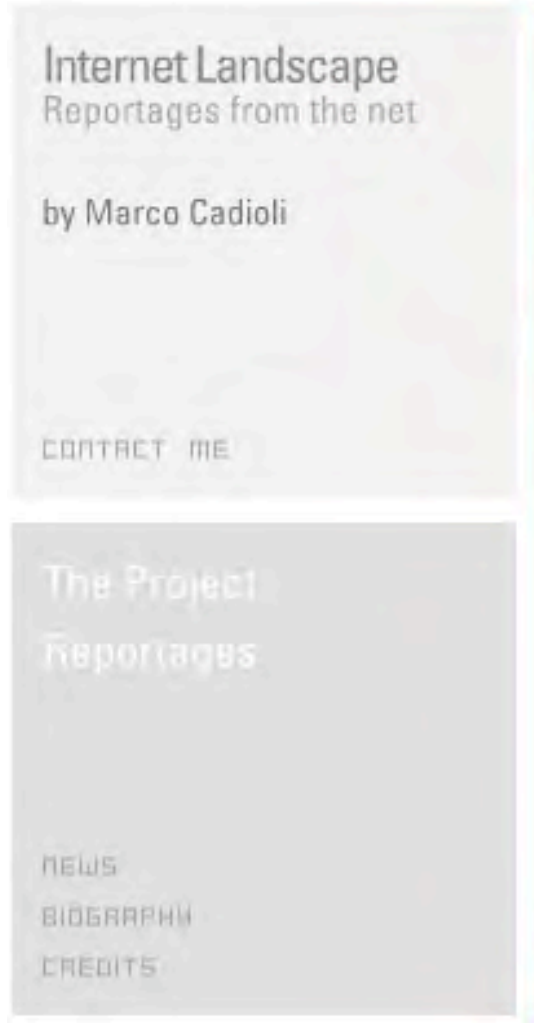

\section{I take shots of the net.}

At any given time I can catch

the reality beyond the screen.

I can tell about places I have been.

I can seize the moment and focus

on time and place.

I can record experiences.

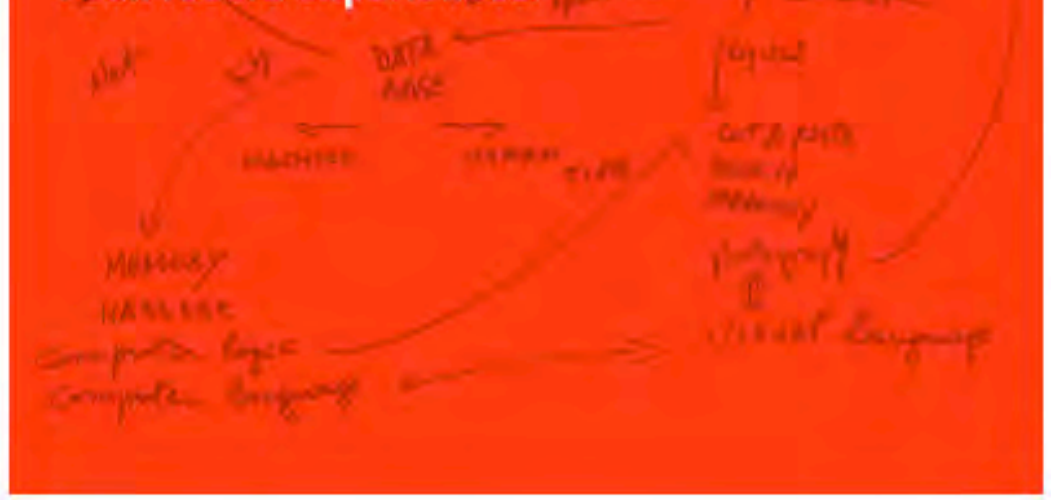

fig.21. internet landscape project publicado em http://rhizome.org.

Sendo assim, uma outra questão colocada por estes experimentos é da necessidade de se desenvolver instrumentos de representação capazes de lidar com a dinâmica espacial contemporânea na concepção do projeto. Por outro lado, os experimentos apontam para uma necessidade de se desenvolver também uma sensibilidade para as questões urbanas. O distanciamento e alienação do arquiteto e do urbanista só podem ser questionados a partir de uma sensibilização não apenas do arquiteto, mas principalmente de todos os atores envolvidos no processo de dinamização do urbano. A sensibilização urbana talvez seja um novo papel do arquiteto e do designer que passa a atuar efetivamente como um produtor cultural, o produtor e difusor de uma cultura urbana. Um papel que se confunde com 0 do artista e que trás para a arquitetura uma postura crítica pronta para ser constantemente resgatada. 
referências bibliográficas 
- BAUMAN, Zygmunt. "Mal Estar da Pós-Modernidade" Rio de Janeiro: Jorge Zahar, 1998

- $\quad$ BAUMAN, Zygmunt. "Modernidade Líquida" Rio de Janeiro: Jorge Zahar, 2001

- BELL, Daniel. 1962. The End of Ideology. New York: The Free Press

- CALDEIRA, Tereza P. R. 2003. Cidade de Muros. São Paulo: EDUSP/Ed. 34

- DEBORD, Guy. 1997. Comentários Sobre a Sociedade do Espetáculo. Rio de Janeiro: Contraponto

- DUARTE, Fabio. "Crise das Matrizes Espaciais" São Paulo: Perspectiva, 2002

- HARVEY, David. A Condição Pós-Moderna. São Paulo: Loyola, 1989

- JACQUES, Paola. (Org.) "Apologia da Deriva - Escritos Situacionistas Sobre a Cidade" Rio de Janeiro: Casa da Palavra, 2003

- LEFEBVRE, Henri. 1991. The Production of Space. Oxford: Blackwell Publishing Ltd.

- LEFEBVRE, Henri. 2004. A Revolução Urbana. Belo Horizonte: Editora UFMG

- LEFEBVRE, Henri. 2004. Rhythmanalysis: Space, Time and Every Day Life. London: Continuum

- LIPOVETSKY, Gilles. 2004. Os Tempos Hipermodernos. São Paulo: Barcarolla

- ROSS, Kristen. 1983. Henri Lefebvre on the Situacionist International

- SANTOS, Milton. 1997. Metamorfoses do Espaço Habitado. São Paulo: HUCITEC

- SANTOS, Milton. 2002. A Natureza do Espaço. São Paulo: EDUSP

- SIMMEL, Georg. A Metrópole e a Vida Mental. in: VELHO, O. G. (org). 1973. O Fenômeno Urbano. Rio de Janeiro: Jorge Zahar.

- SOLA-MORALES RUBIO, Ignasi. "Topographies of Contemporary Architecture" Cambridge: MIT Press, 1996

- SOLÀ-MORALES, Ignasi. Territórios. Barcelona: Gustavo Gilli, 2002.

- TCHUMI, Bernard. "Architecture and Disjunction" Cambridge: MIT Press, 1996

- VIRILIO, Paul, "Landscape of Events" Cambridge: MIT Press, 2001

- VIRILIO, Paul, "O Espaço Crítico" São Paulo: Ed. 34, 1999

- WIRTH, Louis. O Urbanismo Como Modo de Vida. in: VELHO, O. G. (org). 1973. O Fenômeno Urbano. Rio de Janeiro: Jorge Zahar.

- "Hyper Surface Architecture II" - Architetcural Design vol. 691999 edited by Stephen Perrella

- $\quad$ AUGE, Marc. "Não Lugares" Campinas: Ed. Papirus, 1994

- $\quad$ ARANTES, Pedro Fiori. "Arquitetura Nova" São Paulo: Ed. 34, 2002

- BAUMAN, Zygmunt. "Comunidade" Rio de Janeiro: Jorge Zahar, 2003

- BAUMAN, Zygmunt. "Globalização" Rio de Janeiro: Jorge Zahar, 1999

- BELL, Daniel, "The Coming of Post-Industrial Society" New York: Basic Books, 1999

- BENKO, Georges; STROHMAYER, Ulf. (Orgs.) "Space and Social Theory - Interpreting Modernity and Postmodernity" Oxford: Blackwell, 1997

- BETSKY, Aeron. (editor) "Scanning: The Aberrant Architectures of Diller + Scofidio"

- BOERI, Stephan; KOOLHAAS, Rem. "Mutations" Barcelona: ACTAR, 2001

- BRISSAC PEIXOTO, Nelson; MG-ES Um Sistema Infra Estrutural. C.Fabriciano: CAU, 2003 [pdf disponível para download no site: http://www.pucsp.br/artecidade/novo/publicacoes/MG_ES1.pdf (acessado em 10/07/2005)

- BRUZZI, Hygina M. "Do Visível ao Tangível - Em Busca de um Lugar Pós-Utópico" Belo Horizonte: C/ Arte, 2001

- CASTELLS, Manuel. "A Questão Urbana" Ed. Paz e Terra, 1993

- CASTELLS, Manuel. "Sociedade em Rede" Ed. Paz e Terra, 1999

- CHOAY, Françoise "Urbanismo" São Paulo: Perspectiva, 1979 
- Dessauce, Marc (editor) "The Inflatable Moment - Pneumatics and Protest in '68" New York: Princeton Architectural Press, 2001

- DILLER, Elizabeth, SCOFIDIO, Ricardo. "Blur: The Making of Nothing"

- DILLER, Elizabeth. "Flesh: Architecture Probes: The Mutant Body of Architecture"

- FAINSTEIN, S. 1997. Justice, Politics and the Creation of Urban Space. in: MERRIFIELD, A., SWYNGEDOUW, E. 1997. The Urbanization of Justice. New York: New York University Press

- FERRO, Sérgio. O Canteiro e o Desenho. São Paulo: Projeto Editores Associados, 1982.

- FIX, Mariana. Parceiros da Exclusão. São Paulo: Boitempo, 201.

- GAUSA, Manuel (editor) "Barcelona - Metapolis 1.0" Barcelona: ACTAR, 1998

- HAYS, K. Michael. (Org.) "Architecture Theory Since 1968" Cambridge: MIT Press, 2000

- INURA. Possible Urban Worlds. Urban Strategies at the End of the 20th Century. Berlin: Ed. Birkhäuser, 2002.

- JACQUES, Paola. "Estética da Ginga" Rio de Janeiro: Casa da Palavra, 2001

- KOOLHAAS, Rem. Delirious New York. New York: Ed. Monacelli Press, 2002.

- KOOLHAAS, Rem; CHUNG, Chuihua Judy; INABA, Jefrfey; LEONG, Sze Tsung (Ed.) "Great Leap Forward Harvard Project On The City 1 - Harvard Design School" Köln: TASHEN, 2001

- KOOLHAAS, Rem; JUDY, Chuihua; INABA, Jeffrey; Sze Tsung Leong (Ed.) "Guide to Shopping - Harvard Project On The City 2 - Harvard Design School" Köln: TASHEN, 2001

- $\quad$ KOOLHAAS, Rem; MAU, Bruce; WERLEMANN, Hans. "S,M,L,XL" Ed. Monacelli-Press, 1998

- KWINTER, Sanford. "Architectures of Time: Toward a Theory of the Event in Modernist Culture"

- LÉVY, Pierre; "Cybercultura" São Paulo: Ed. 34, 1999

- MASS, Winy. (editor) MVRDV: Costa Ibérica Upbeat To The Leisure City Barcelona, ACTAR, 2000

- MASS, Winy; MVRDV. Farmax. Barcelona, ACTAR, 1998

- MITCHELL, Willian, "City of Bits" Cambridge: MIT Press, 1996

- MVRDV (editor) "Projects" Barcelona: ACTAR, 2003

- MVRDV (editor) "Megacity/Datatown". Barcelona: ACTAR, 1999

- NAISBITT, John, "Hight Tech, High Touch" Ed. Cultrix, 2000

- PARENTE, André (Org.) "Imagem Máquina" São Paulo: Ed. 34, 1999

- Projeto AMNESIAS TOPOGRAFICAS; Louise Ganz e Carlos Teixeira. http://www.vazio.com.br

- SANTOS, Milton; "Técnica, Espaço e Tempo. Globalização e Meio Técnico-Cinetífico-Informacional" São Paulo: Hucitec, 1996

- SANTOS, Milton; SILVEIRA, Maria Laura; SOUZA, Maria Adélia. (Orgs.) "Território - Globalização e Fragmentação" São Paulo: Hucitec/Anpur, 1994

- SORKIN, Michael. (org). 1992. Variations on a Theme Park, The New American City and The End of Public Space. New York: Hill and Wang

- SPUYBROEK, Lars. "The Weight of the Image" Rotterdam: NAI Publishers, 2001

- SPUYBROEK, Lars. (NOX) "The Strategy of the Form" Roterdã in: www.v2/nl/DEAF/96/nodes/NOX: Dutch Eletronic Art Festival - Digital Territories, 1996

- TCHUMI, Bernard. "Event Cities" Cambridge: MIT Press, 1994 
anexos 
| imagens - impressos |

conteúdo:

- Playtime

- Futuro House

- Dogville

- panoramas temporários ${ }^{\mathrm{MM}}$

- paisagem temporária ${ }^{\mathrm{MM}}$

- 15 Minutos $^{\mathrm{MM}}$

\section{|DVD-Rom |}

conteúdo:

| multimídia >

- $\quad$ panoramas temporários ${ }^{\mathrm{MM}}$ |

- $\quad$ | paisagem temporária ${ }^{\mathrm{MM}}$ | here, there, where ${ }^{\mathrm{MM}}$ |

| MMSoundscapes ${ }^{\mathrm{MM}}$ >

- | [re]construção de paisagens sonoras |

- $\mid$... da minha varanda |

| vídeos e cenas de filmes >

- $\quad 5305$ fotos [diária urbana] |

- $\mid$ podscape ${ }^{\mathrm{MM}} \mid$

- | cenas dos filmes |

- | CAU; práticas educacionais de sensibilização |

\section{| fotografias >}

- | panoramas temporários ${ }^{\mathrm{MM}}$ |

- $\quad 15$ minutos ${ }^{\mathrm{MM}} \mid$ 
| imagens - impressos |

Playtime 


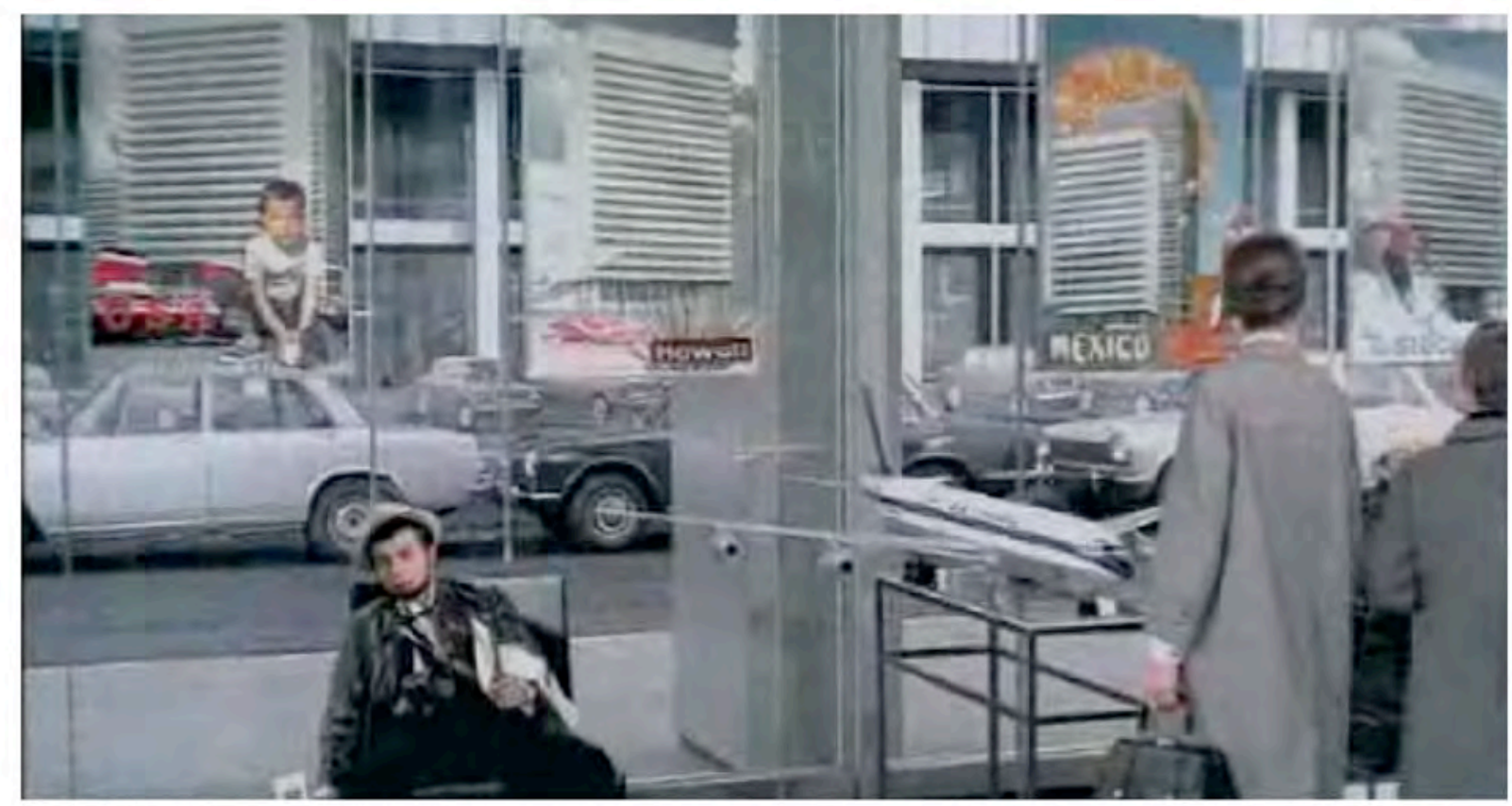

cena do filme Play Time (1967) de Jaques Tati. uma das personagens do filme repara os cartazes turísticos dos principais destinos mundiais; todos iguais.

cena do filme Play Time. a Paris moderna de Tati resgata sua paisagem histórica nos reflexos dos vidros das construções modernas.

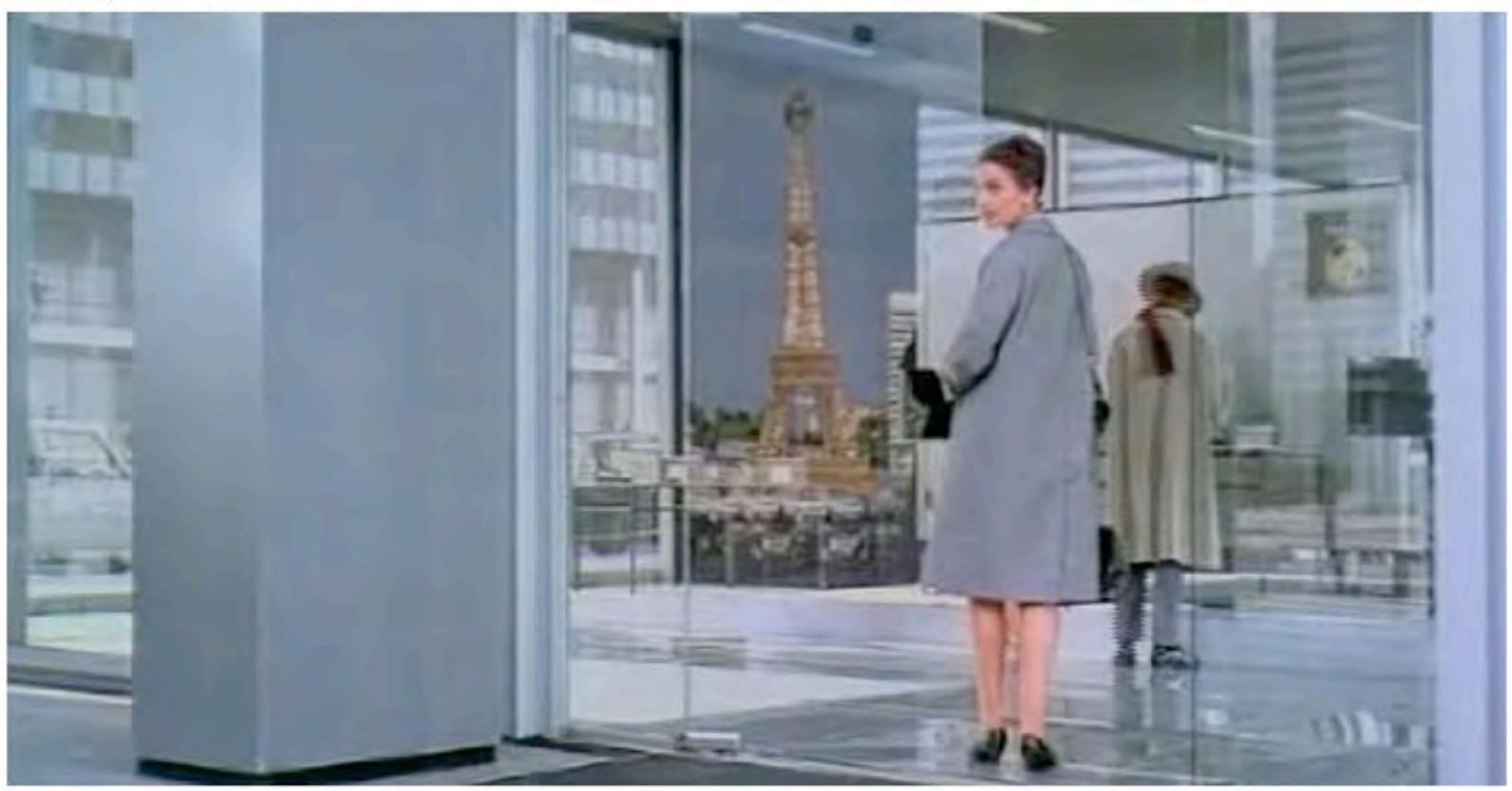




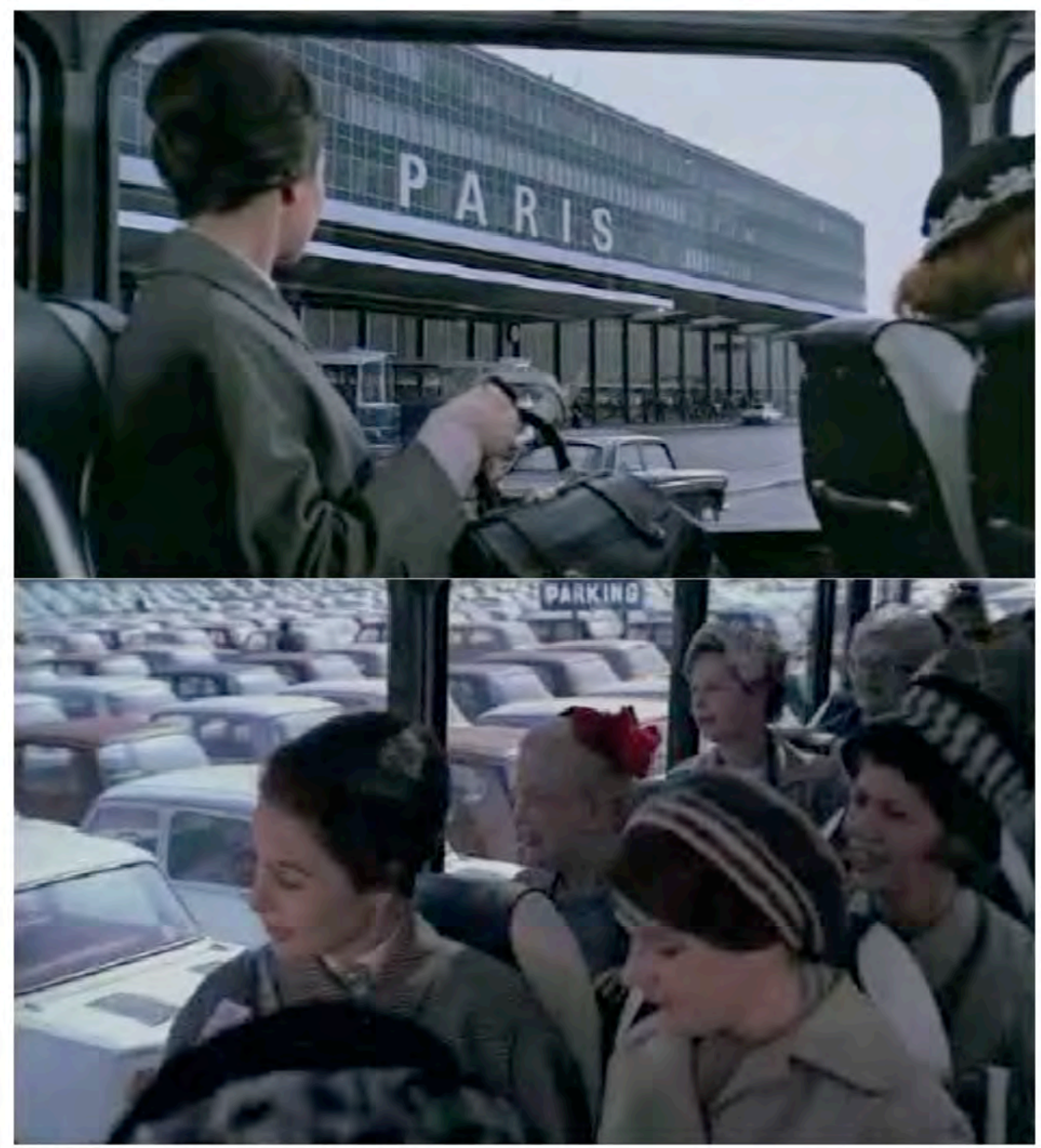

cena do filme Play Time (1967) de Jaques Tati.

"Tativille" em construção. fonte: www.tativille.com

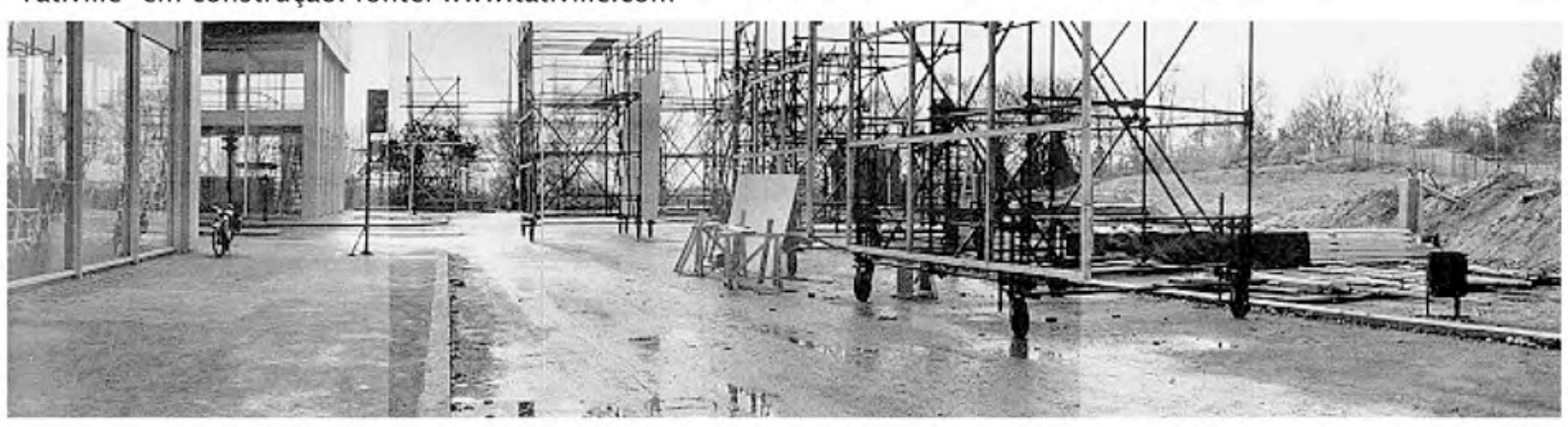


| imagens - impressos |

Futuro House 


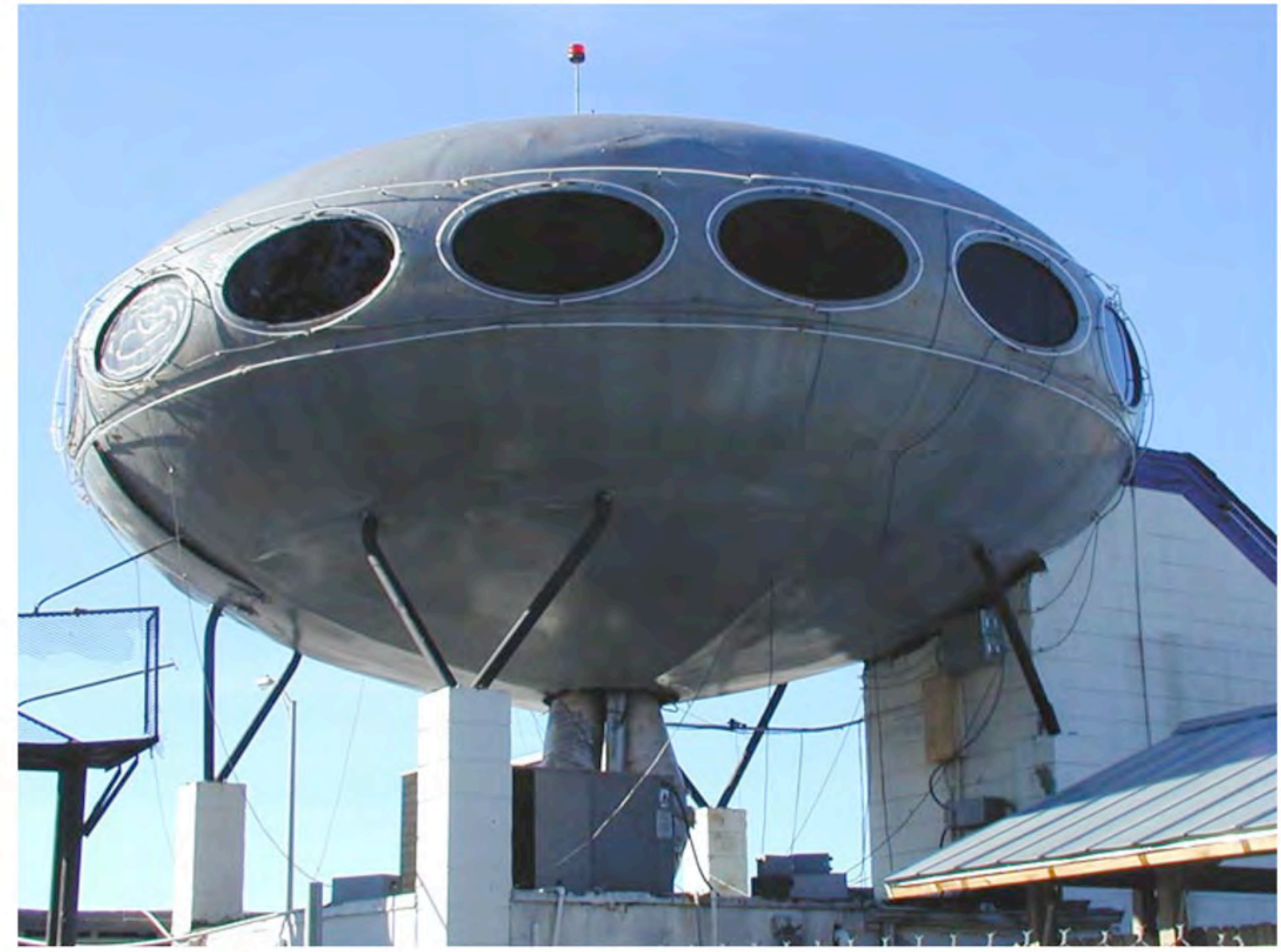

Futuro House instalada no terraço de uma casa.

maquete da Futuro House.

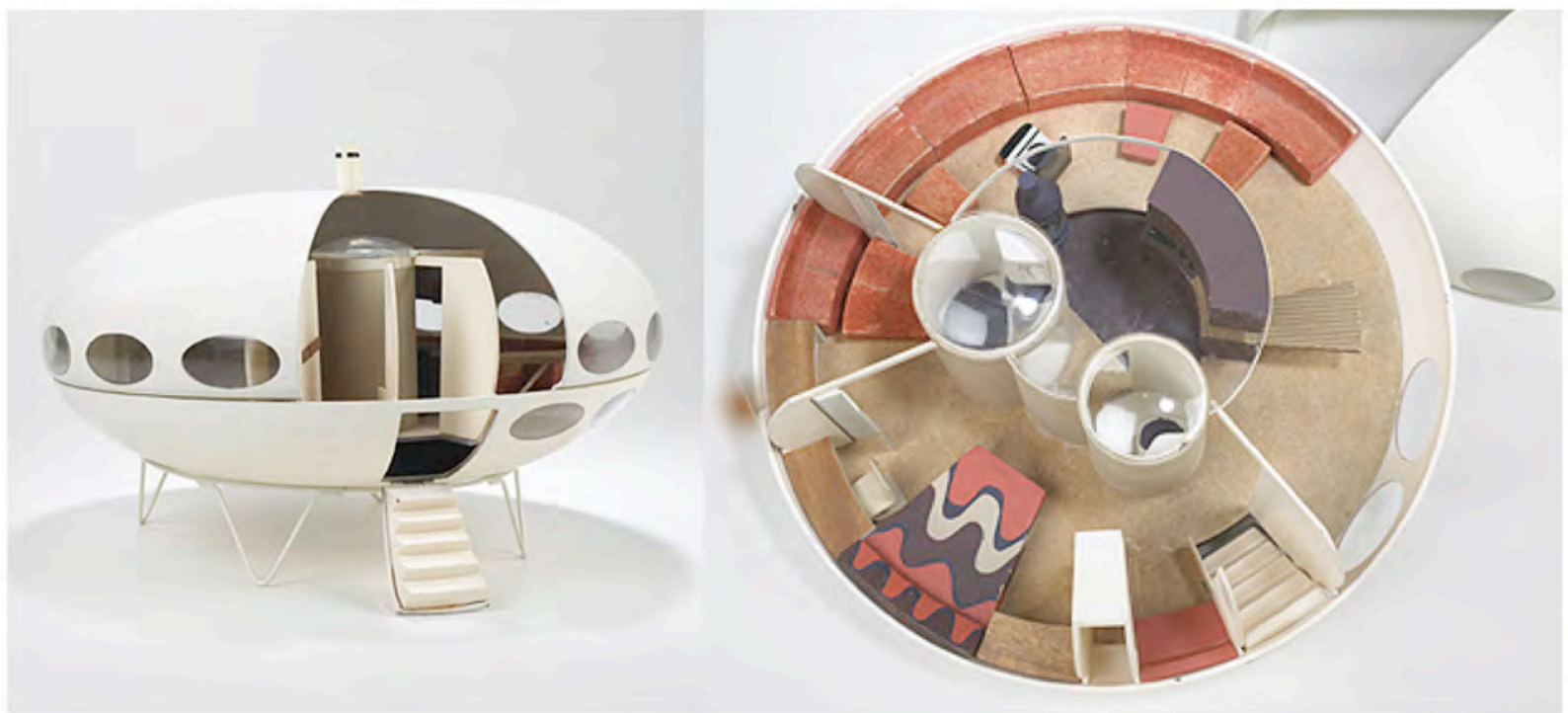


| imagens - impressos |

Dogville 


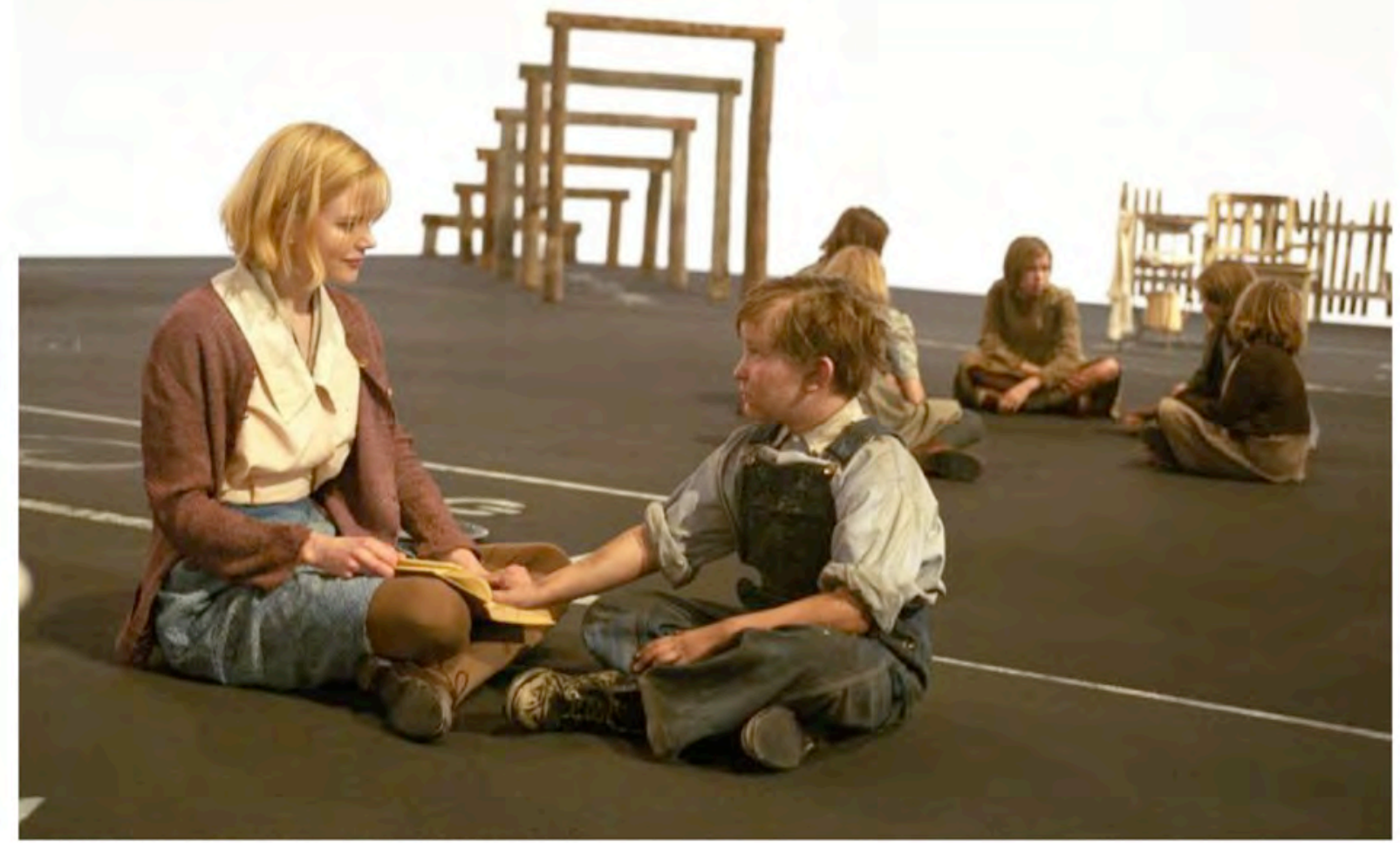

cenas do filme Dogville (2003) de Lars Von Trier.

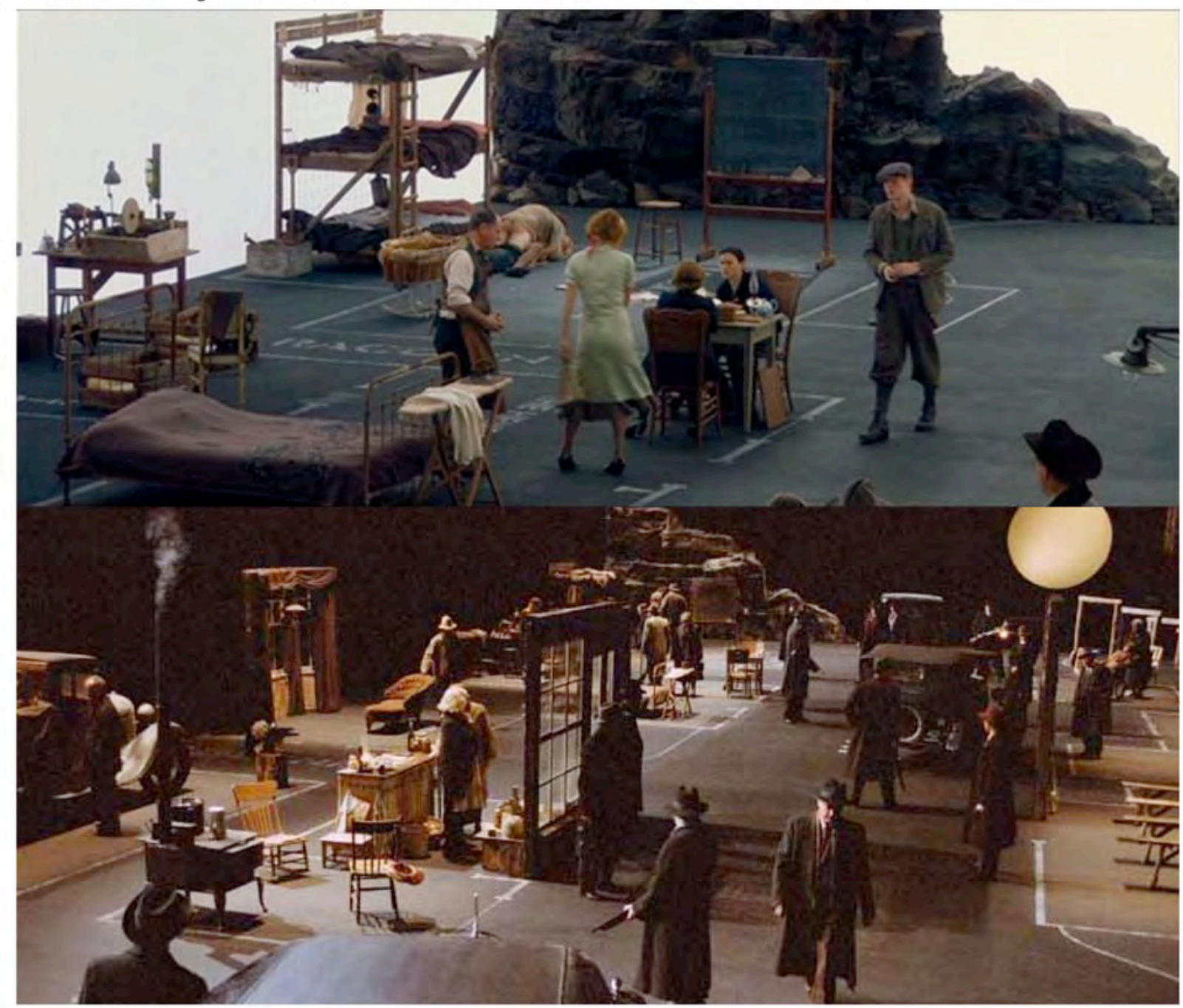




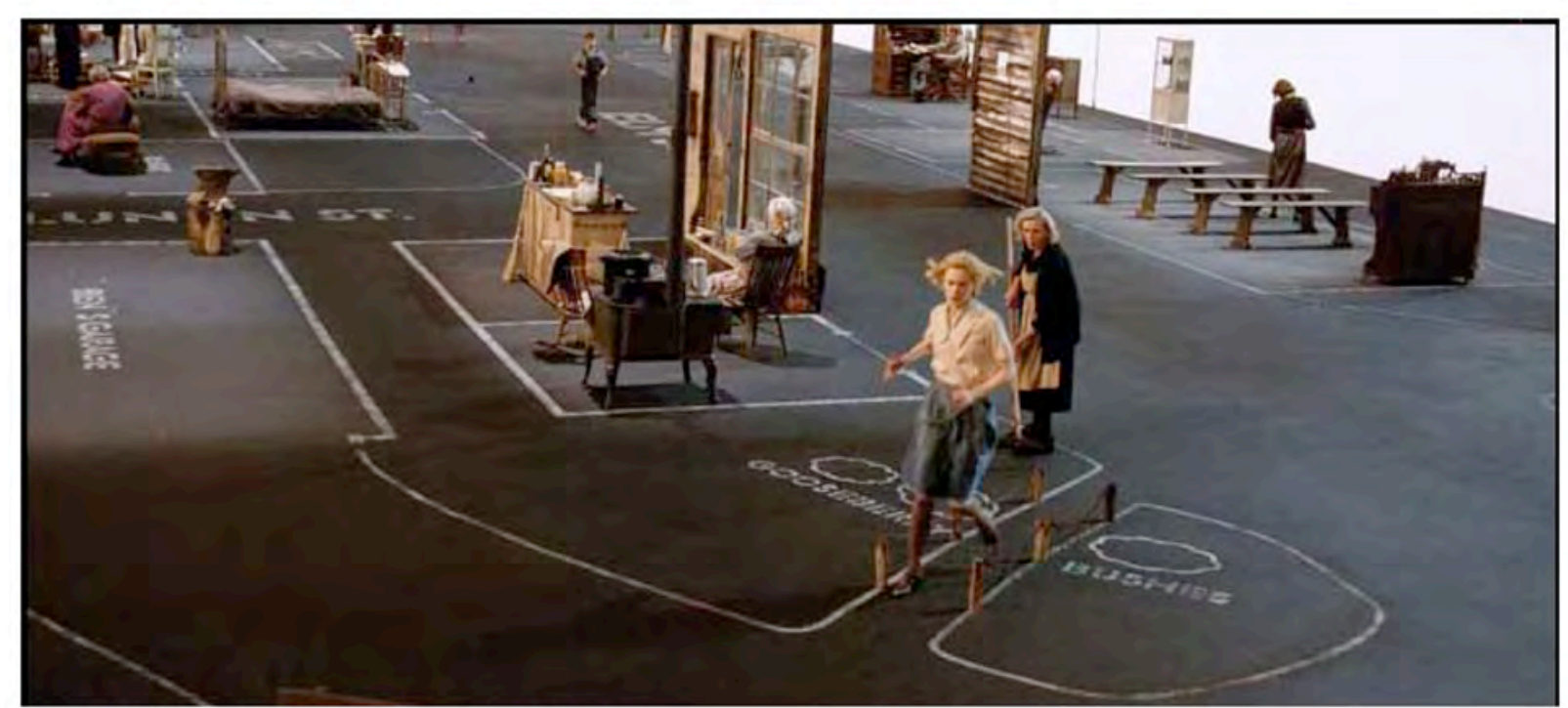

cenas do filme Dogville (2003) de Lars Von Trier.

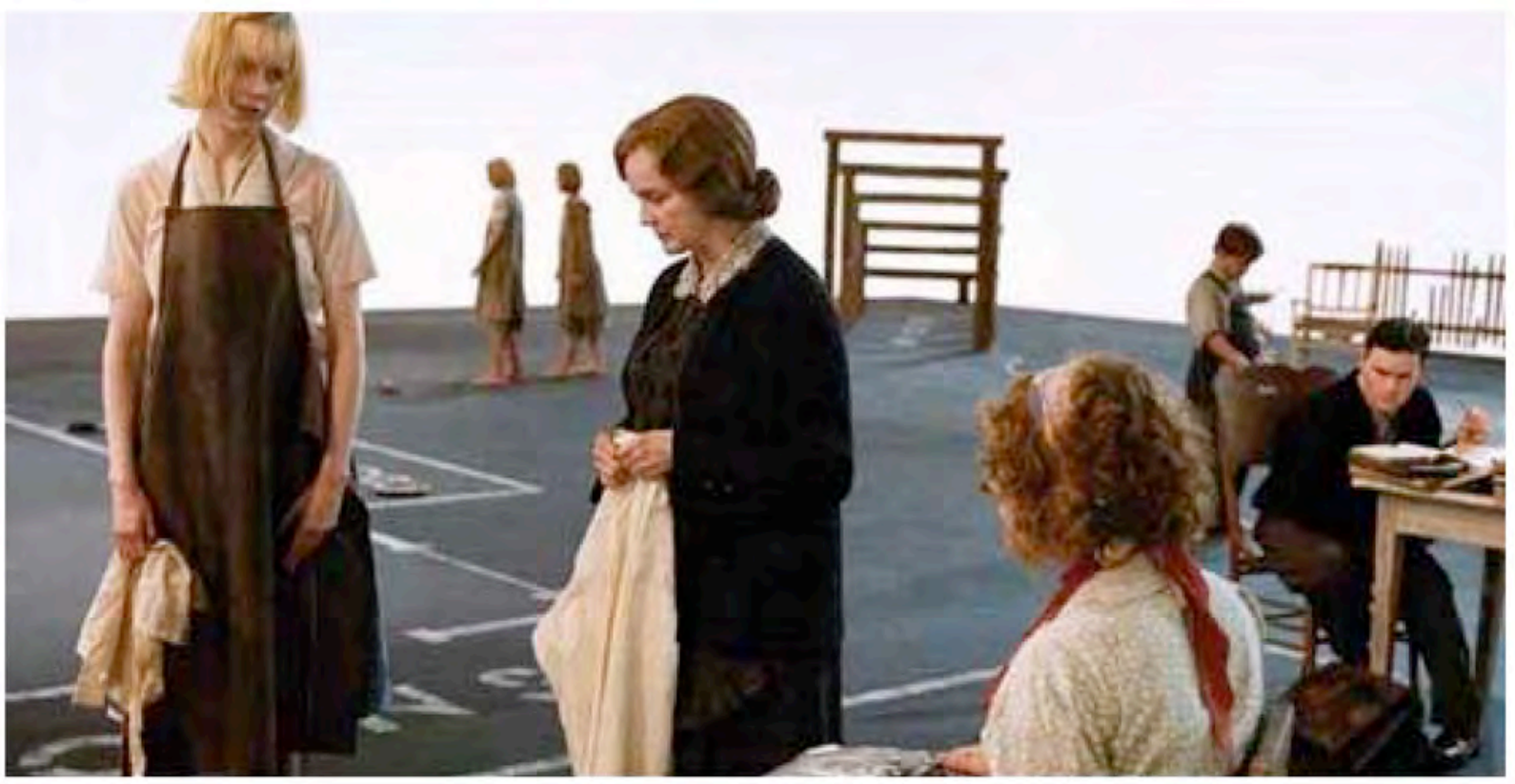


| imagens - impressos |

panoramas temporários ${ }^{\mathrm{MM}}$ 


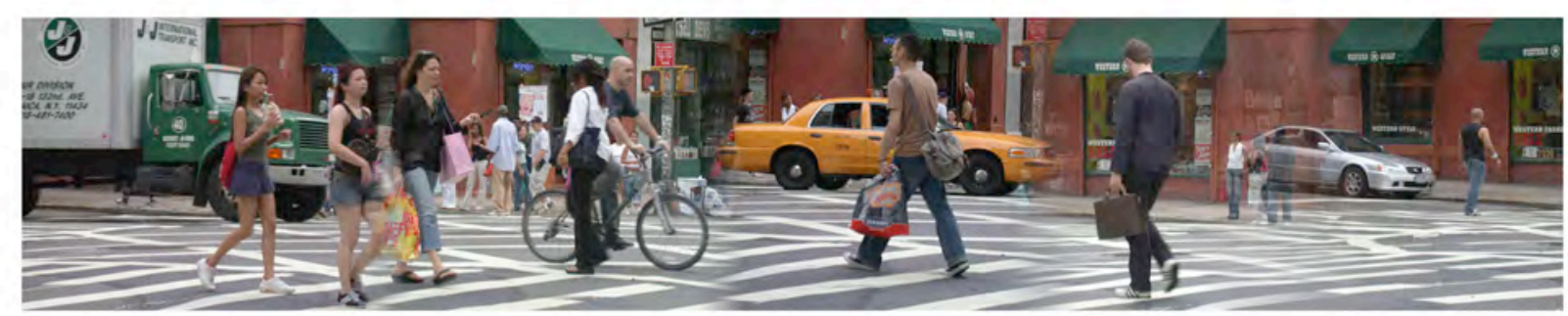

panorama temporário de uma esquina - Soho, NY, julho 2004
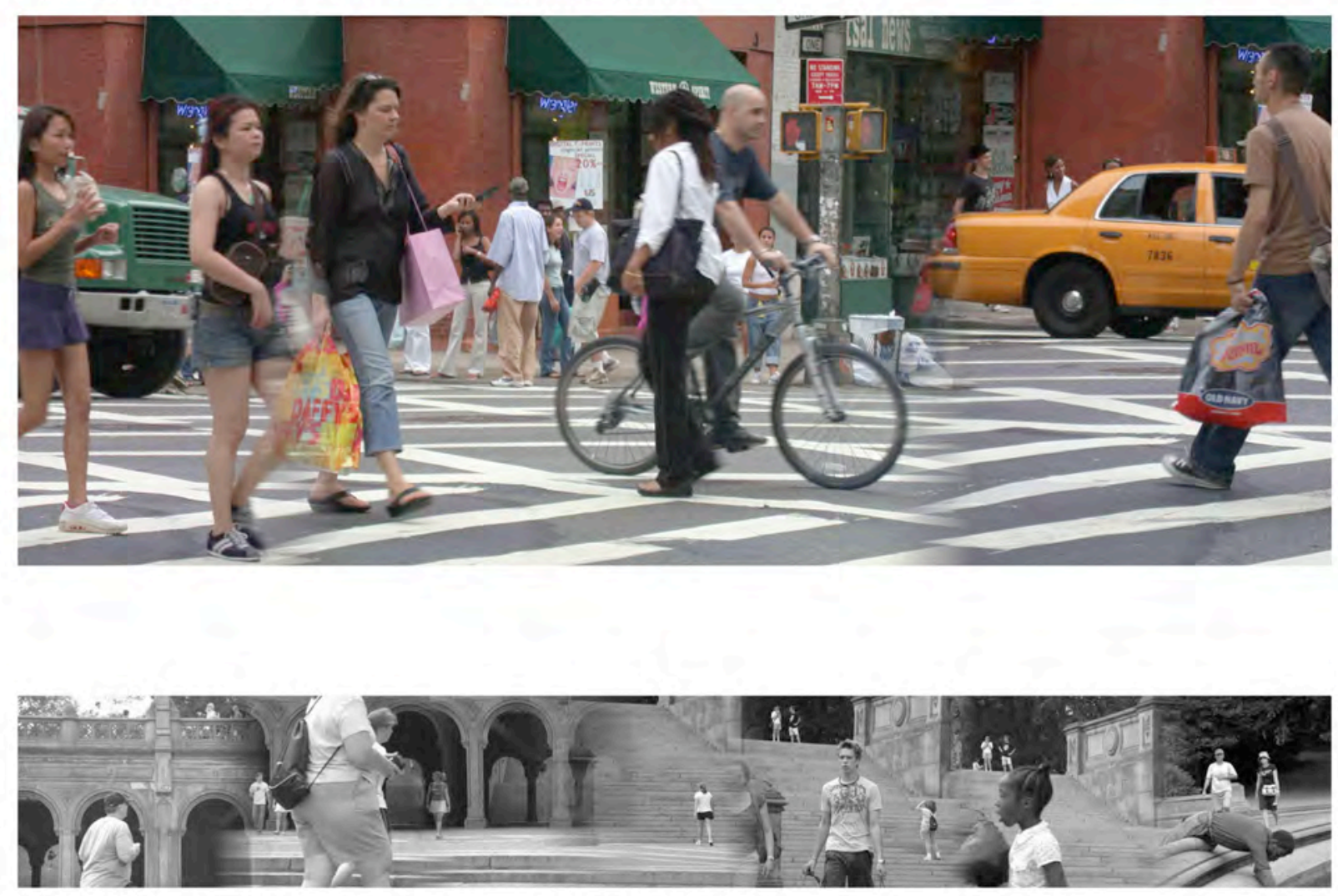

panorama temporário de um parque - Central Park, NY, julho 2004

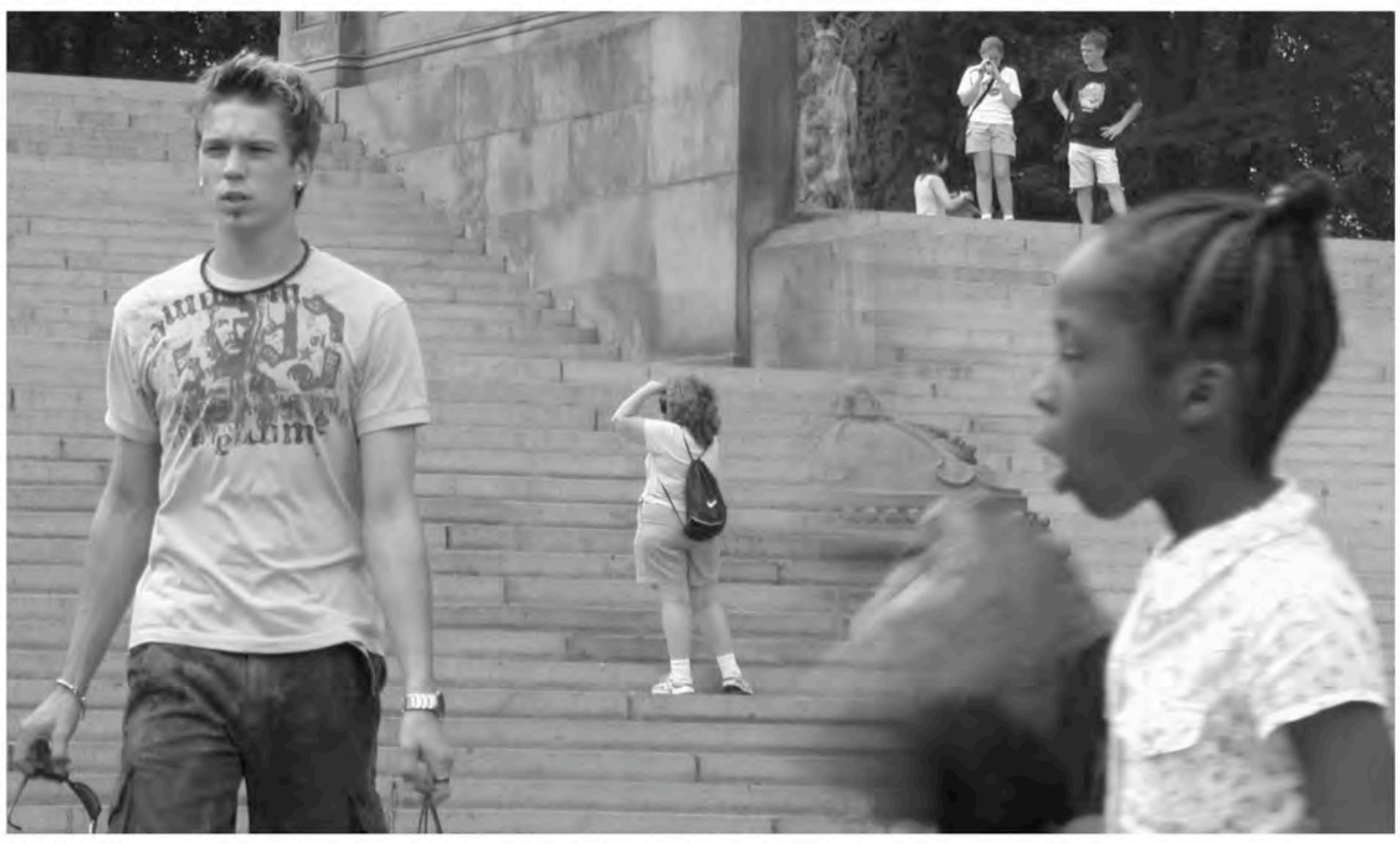




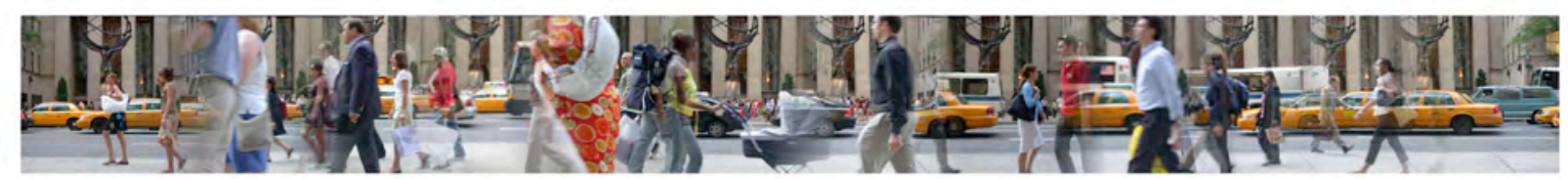

panorama temporário de uma avenida - 5th Avenue, NY, julho 2004
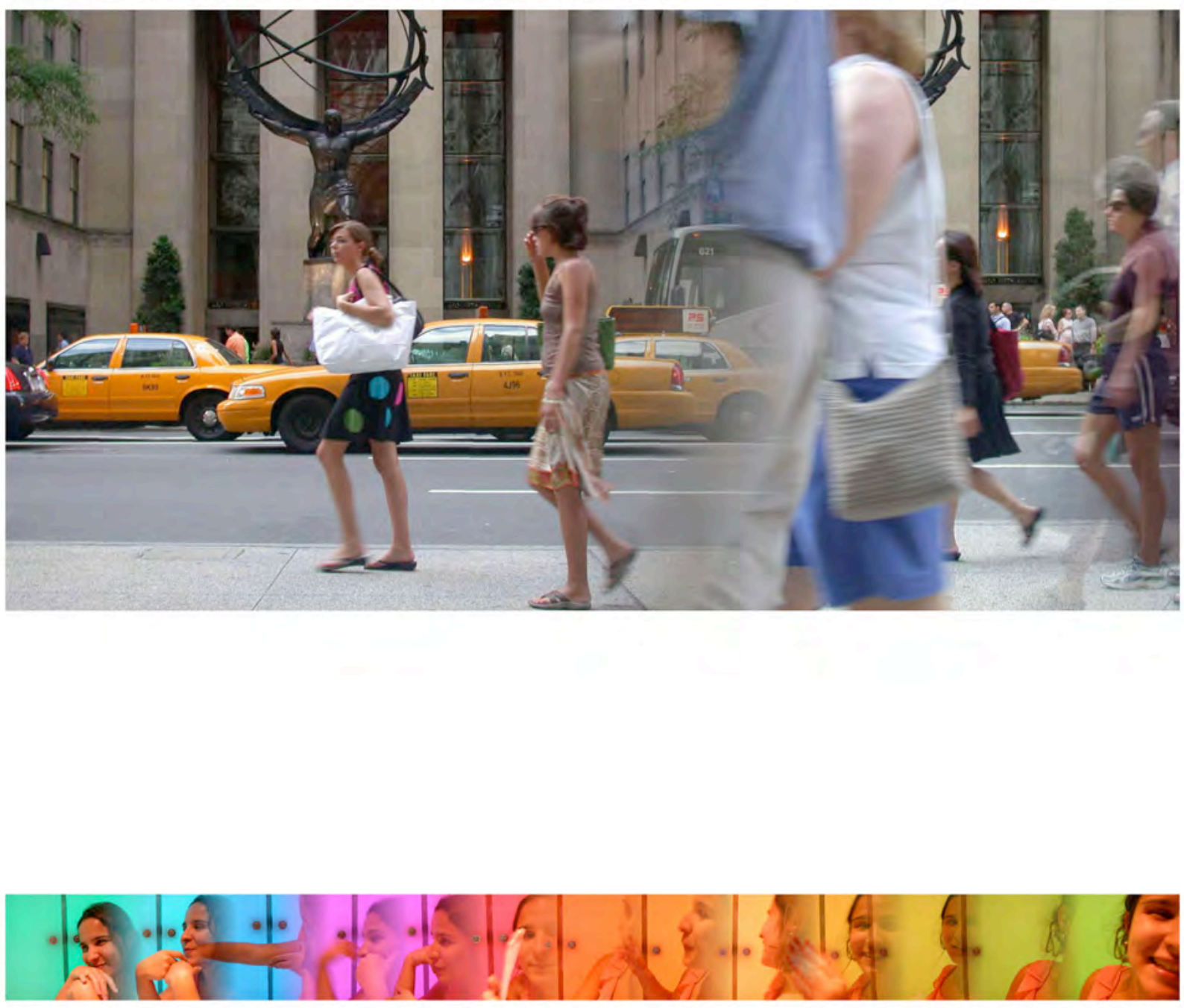

panorama temporário de um almoço - Columbus Center, NY, julho 2004

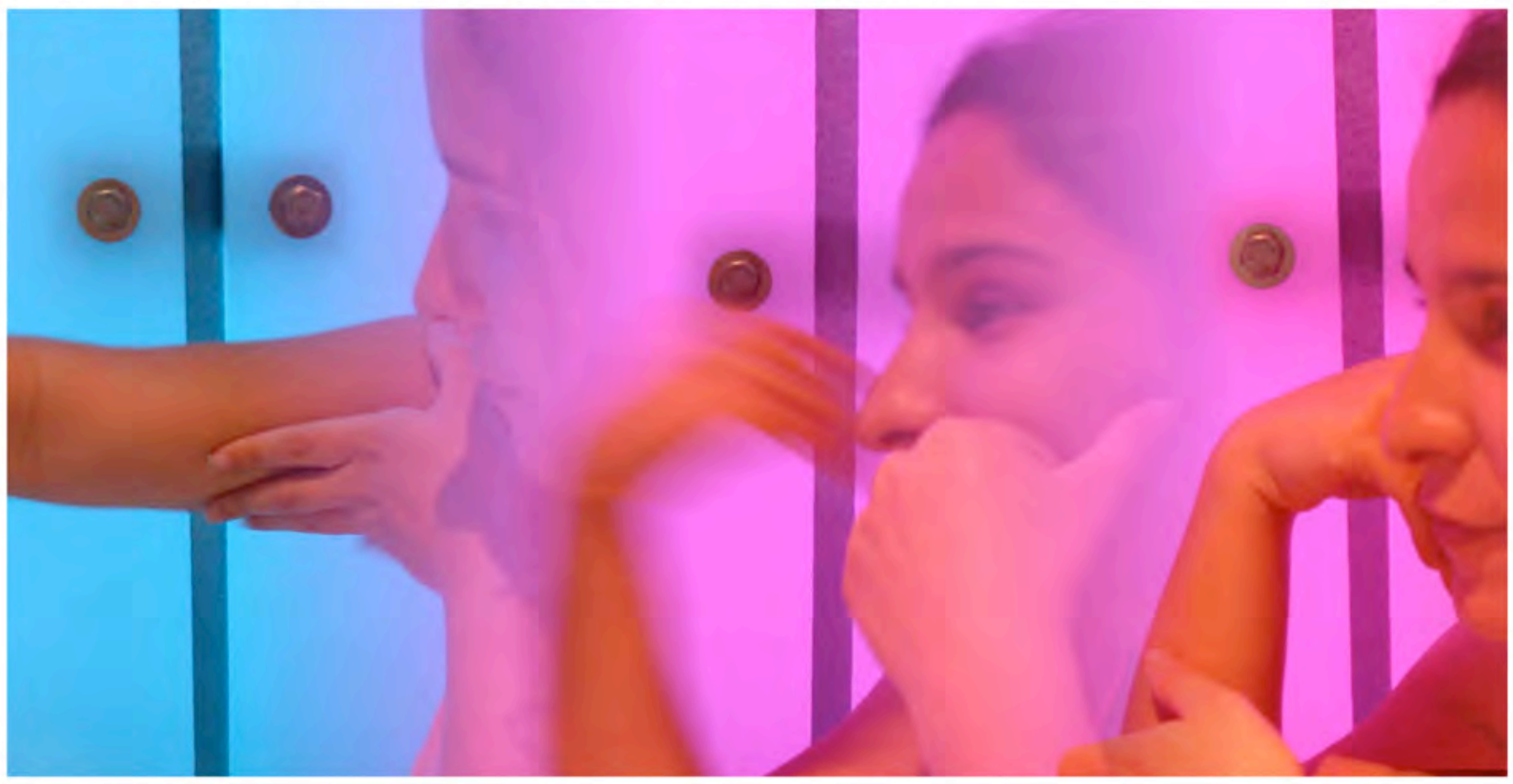



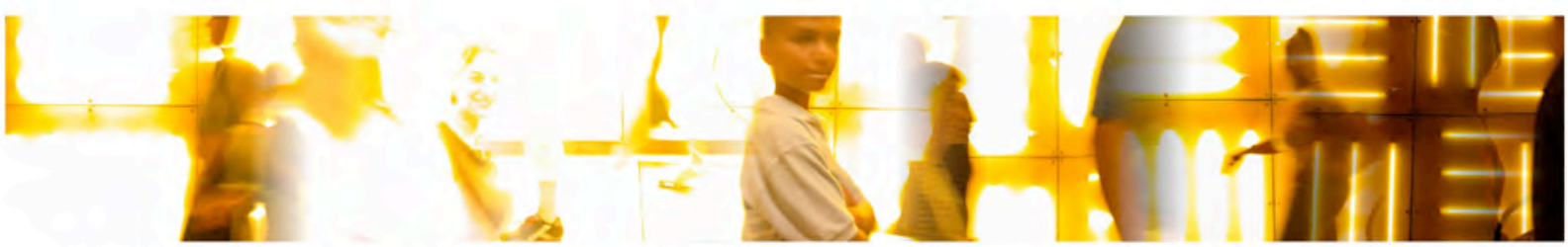

panorama temporário de uma loja de departamentos - Times Square, NY, julho 2004
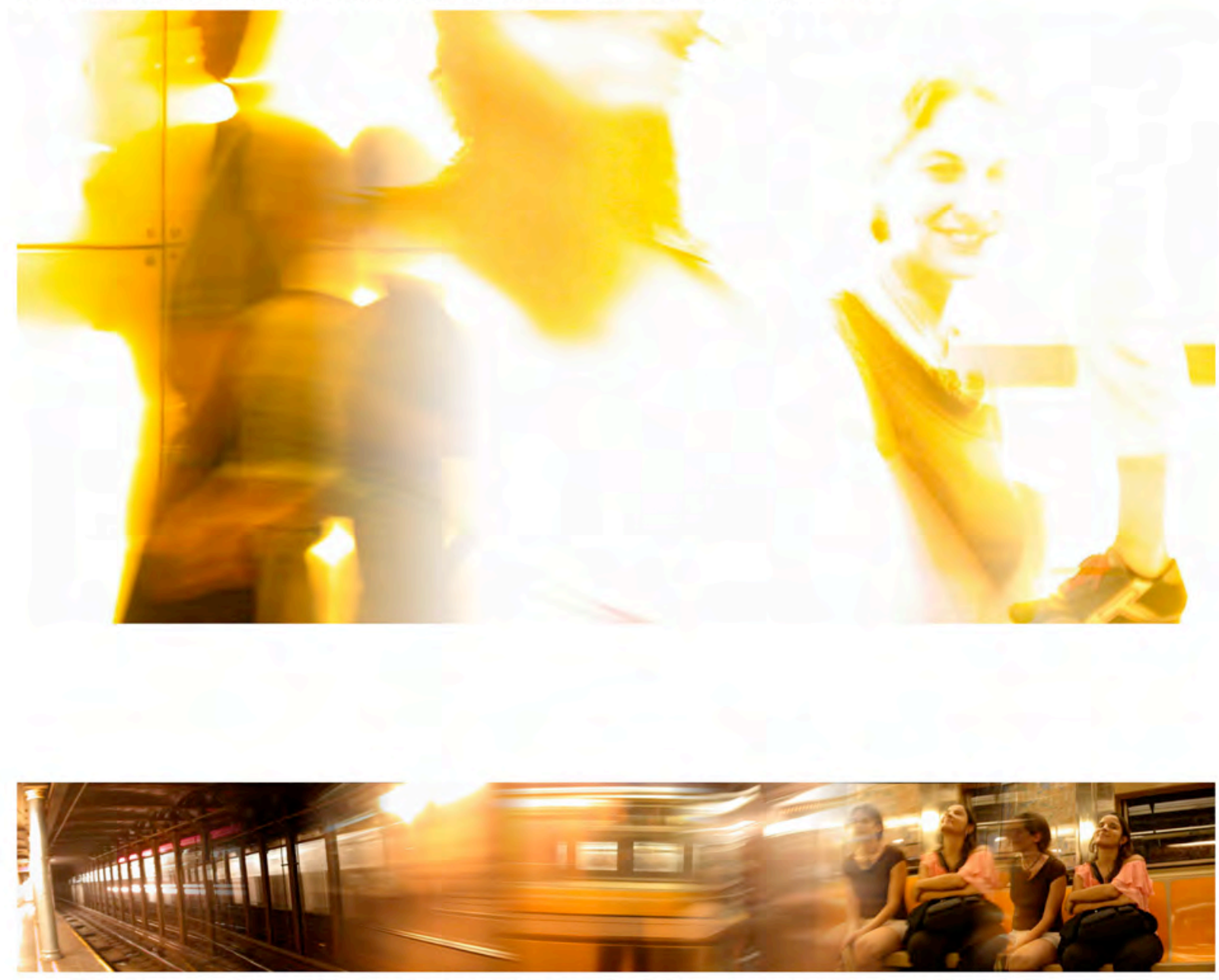

panorama temporário® de uma jornada de metrô - estações e trens do metro, NY, julho 2004

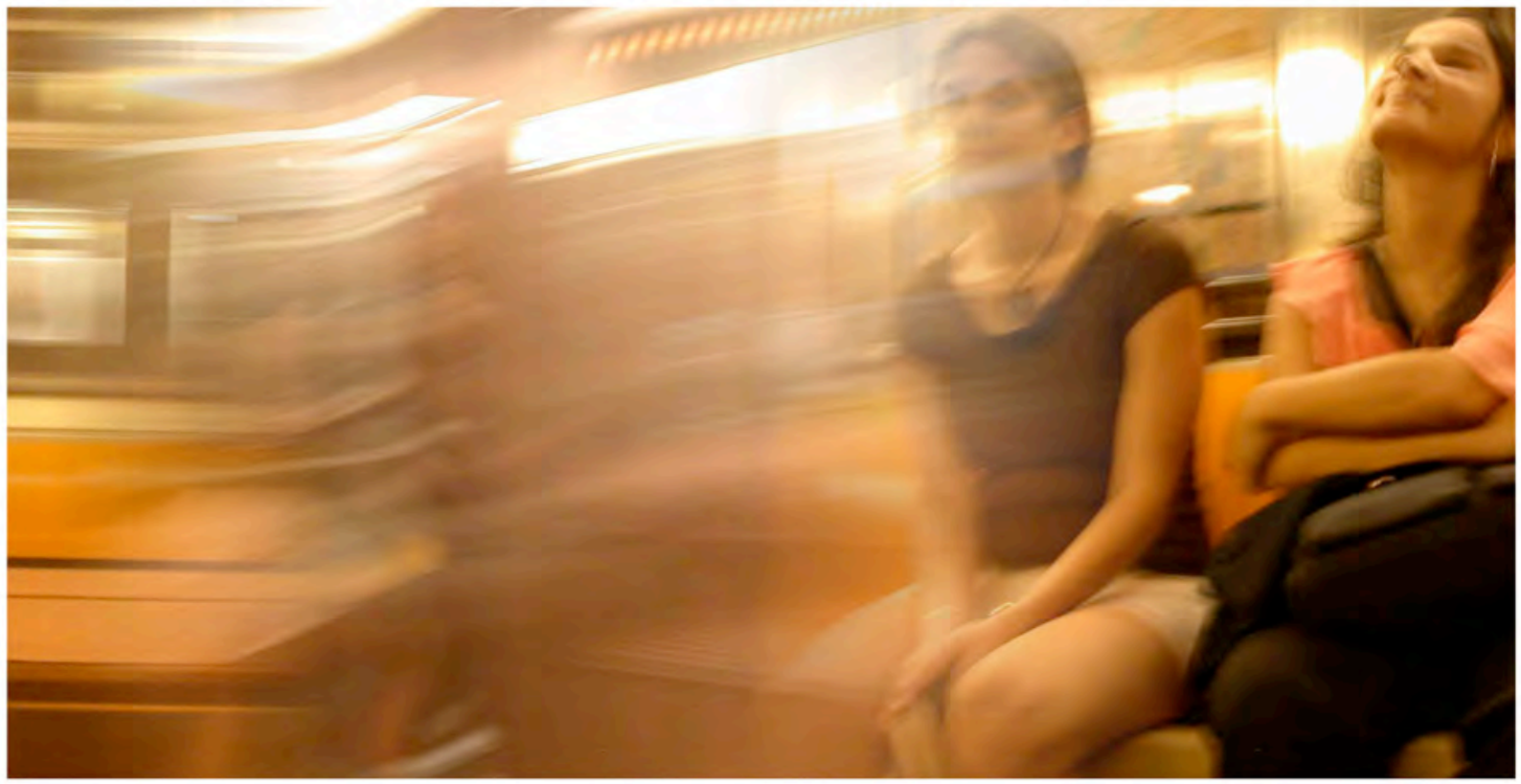


| imagens - impressos |

paisagem temporáriaMM 


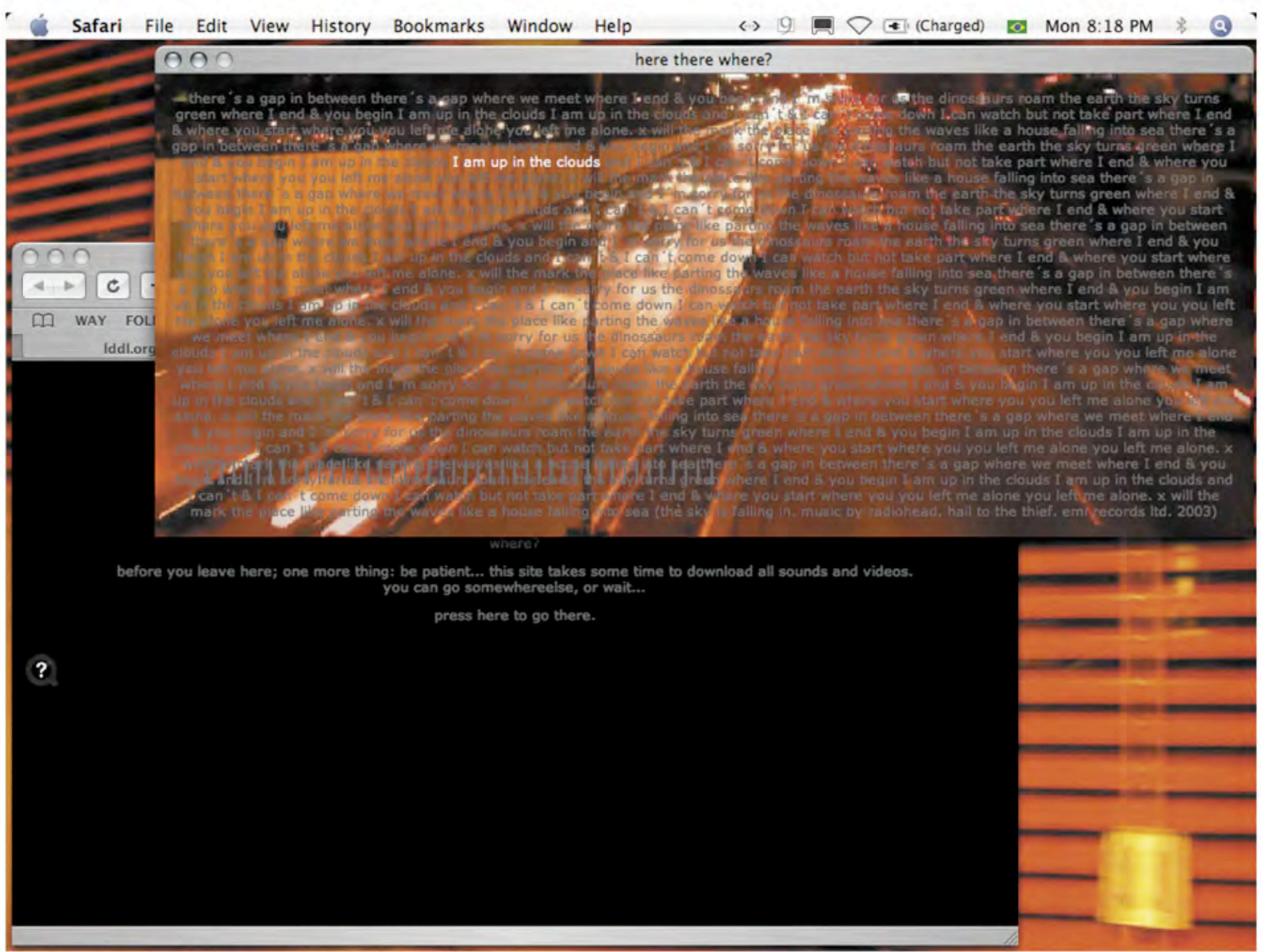

imagens do site interativo na tela do computador.

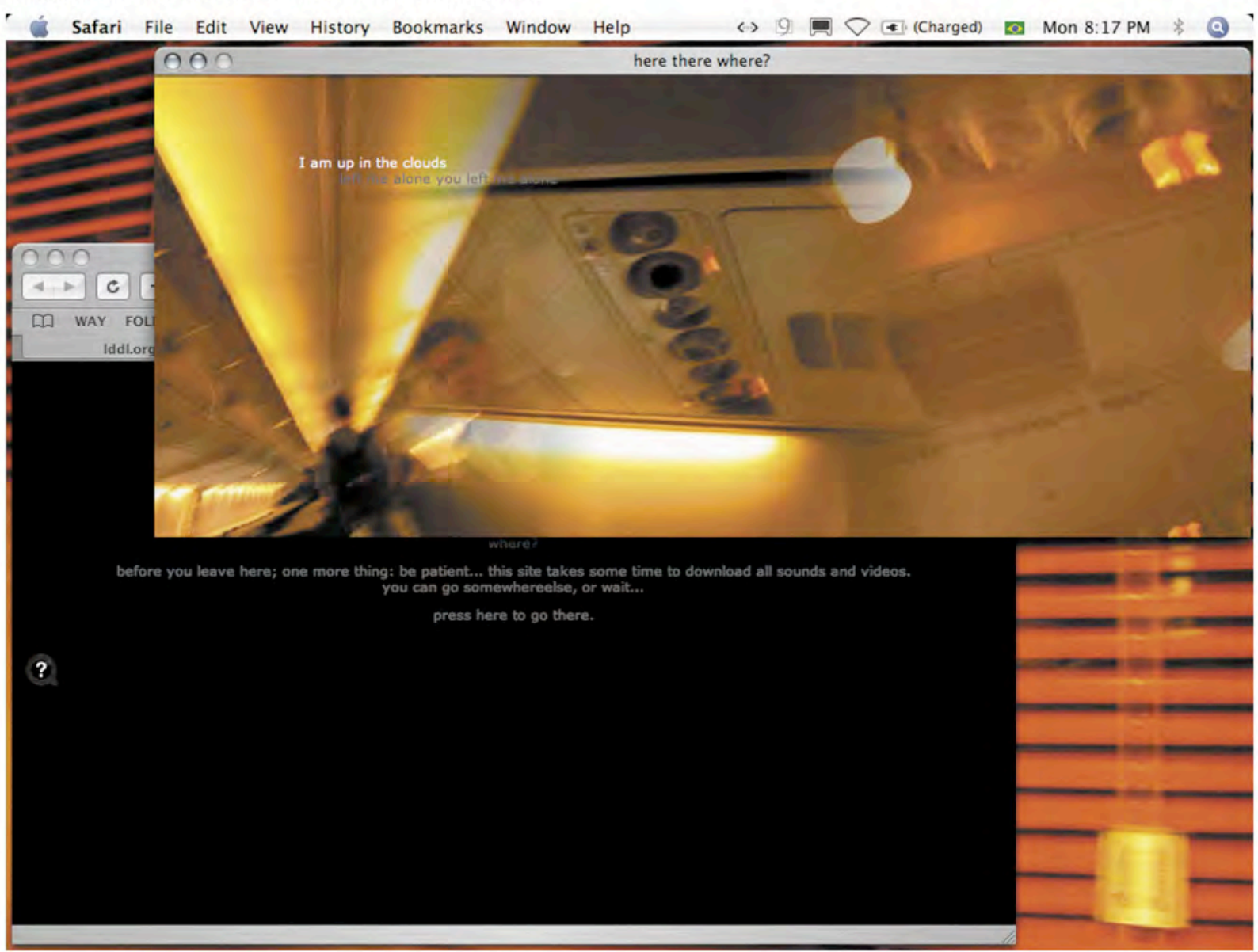




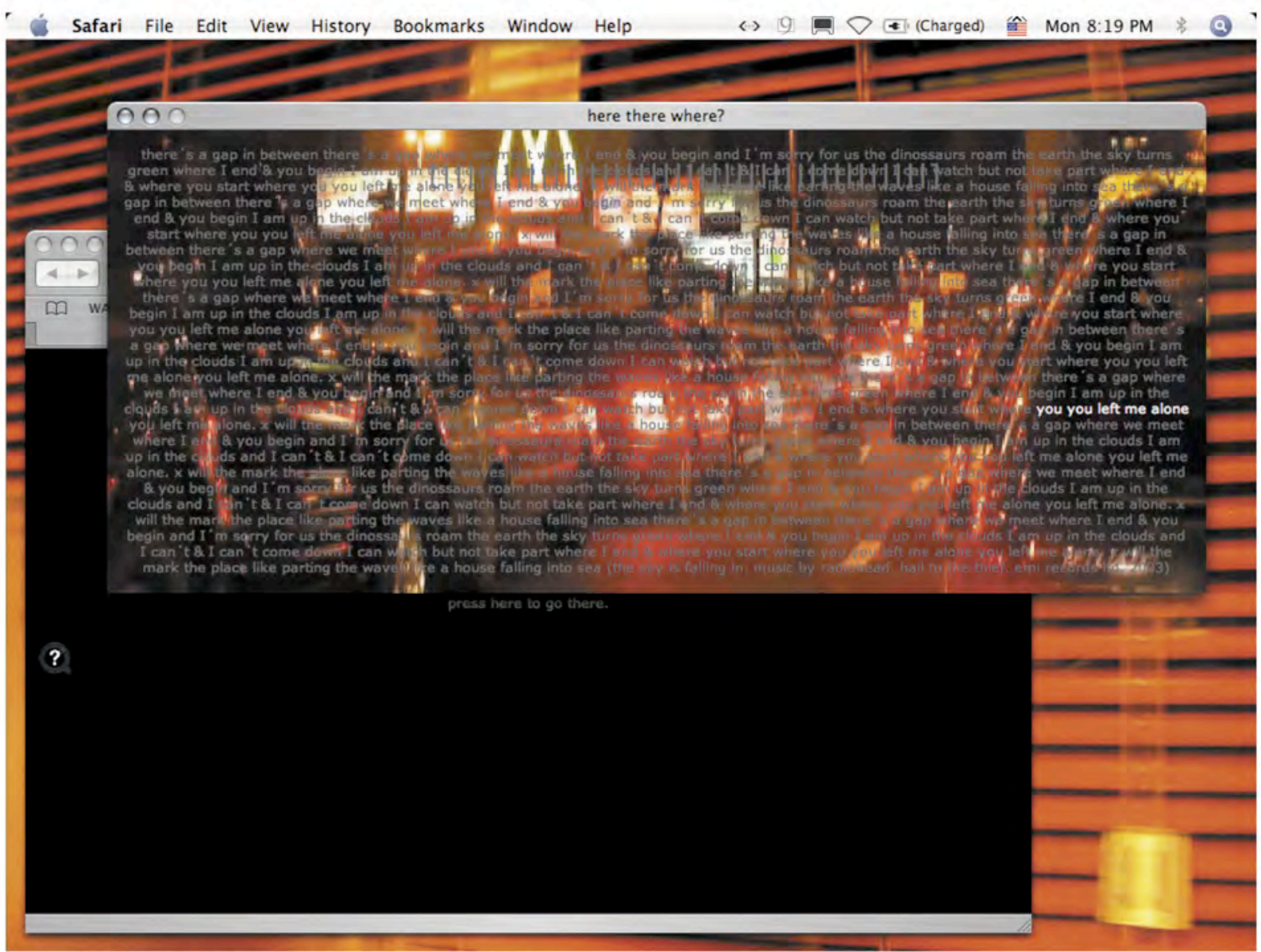

imagens do site interativo na tela do computador.

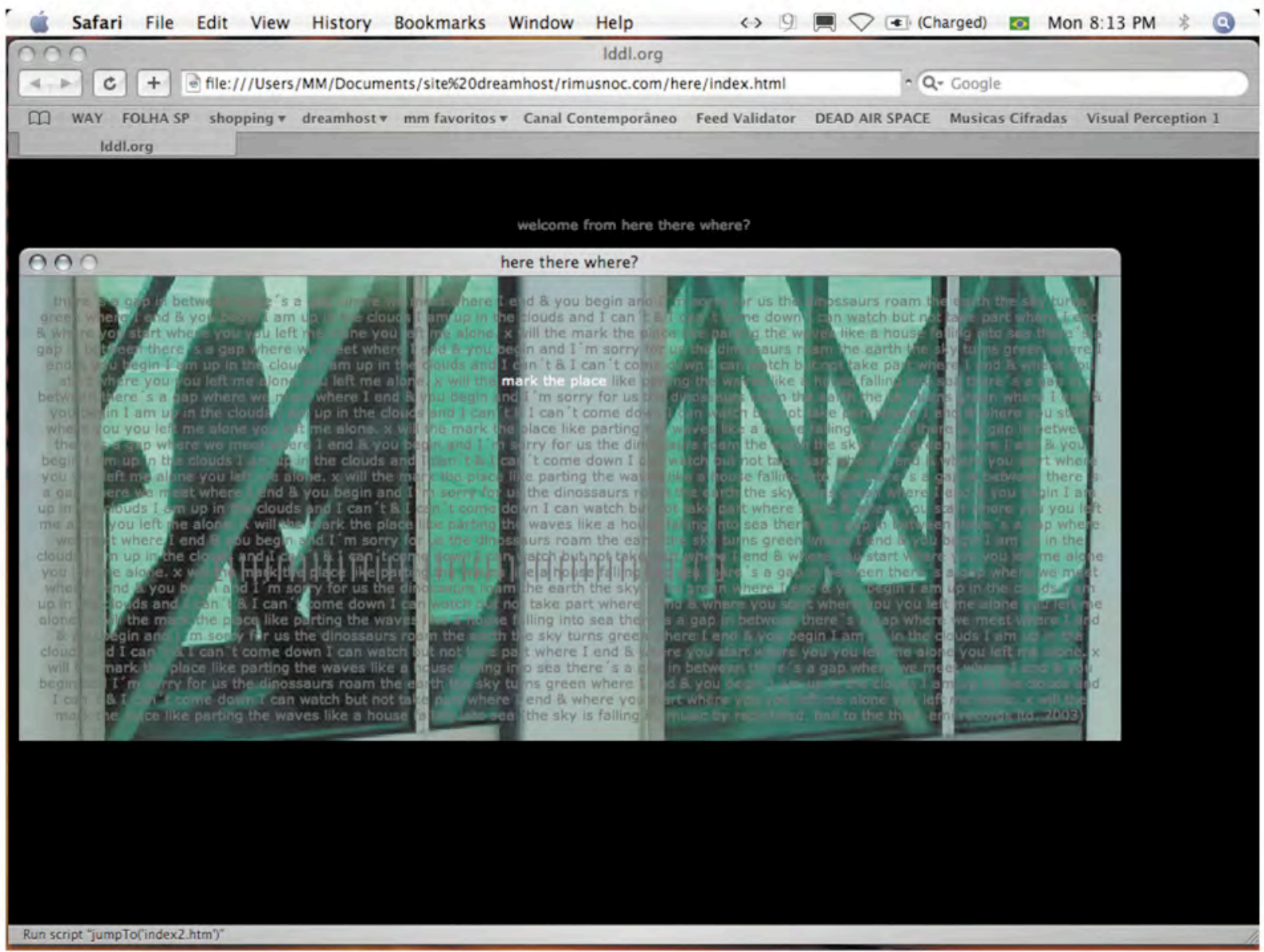


| imagens - impressos |

15 Minutos $^{\mathrm{MM}}$ 


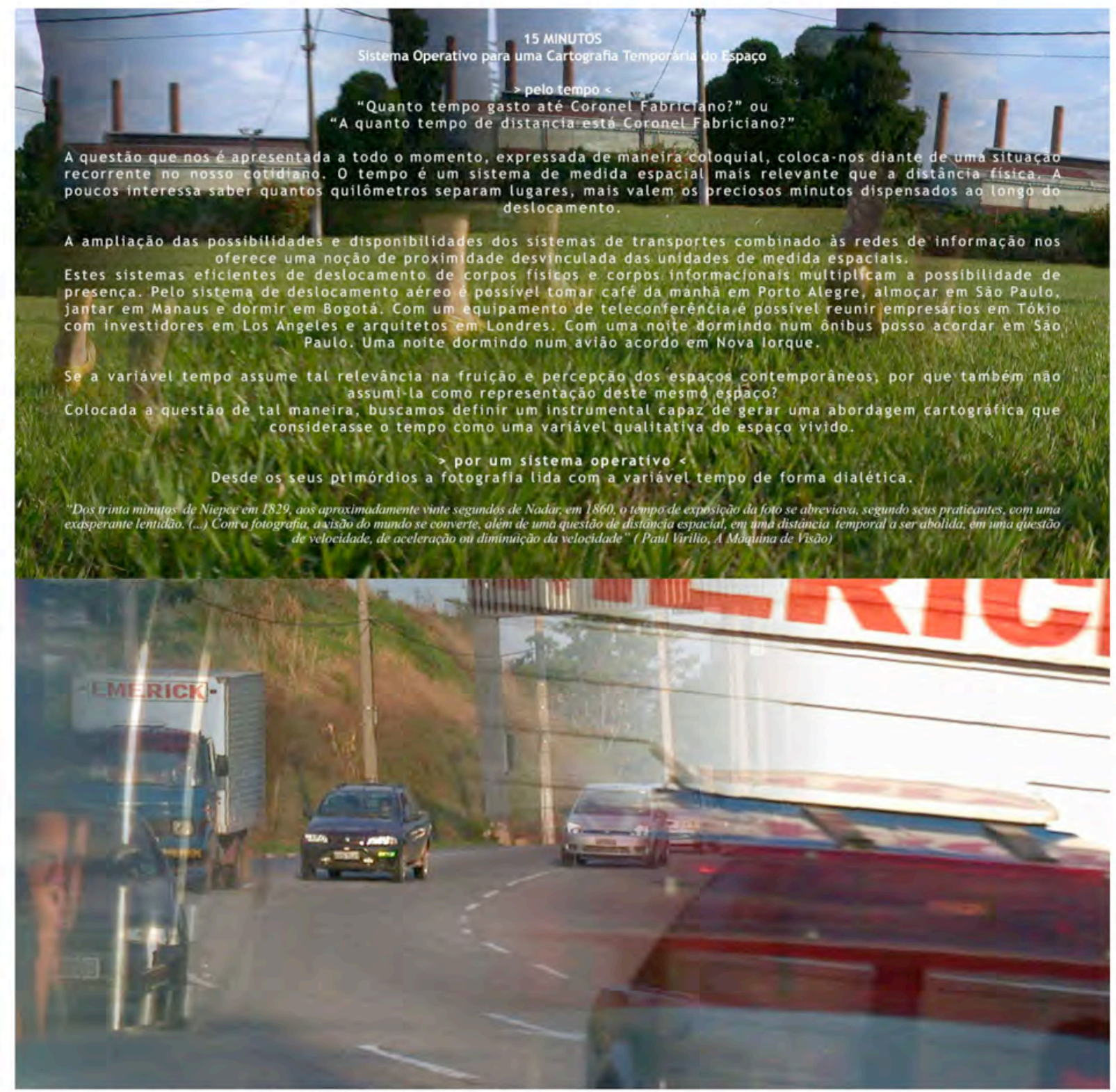

15 minutos, apresentação do ensaio fotográfico e dos panoramas.

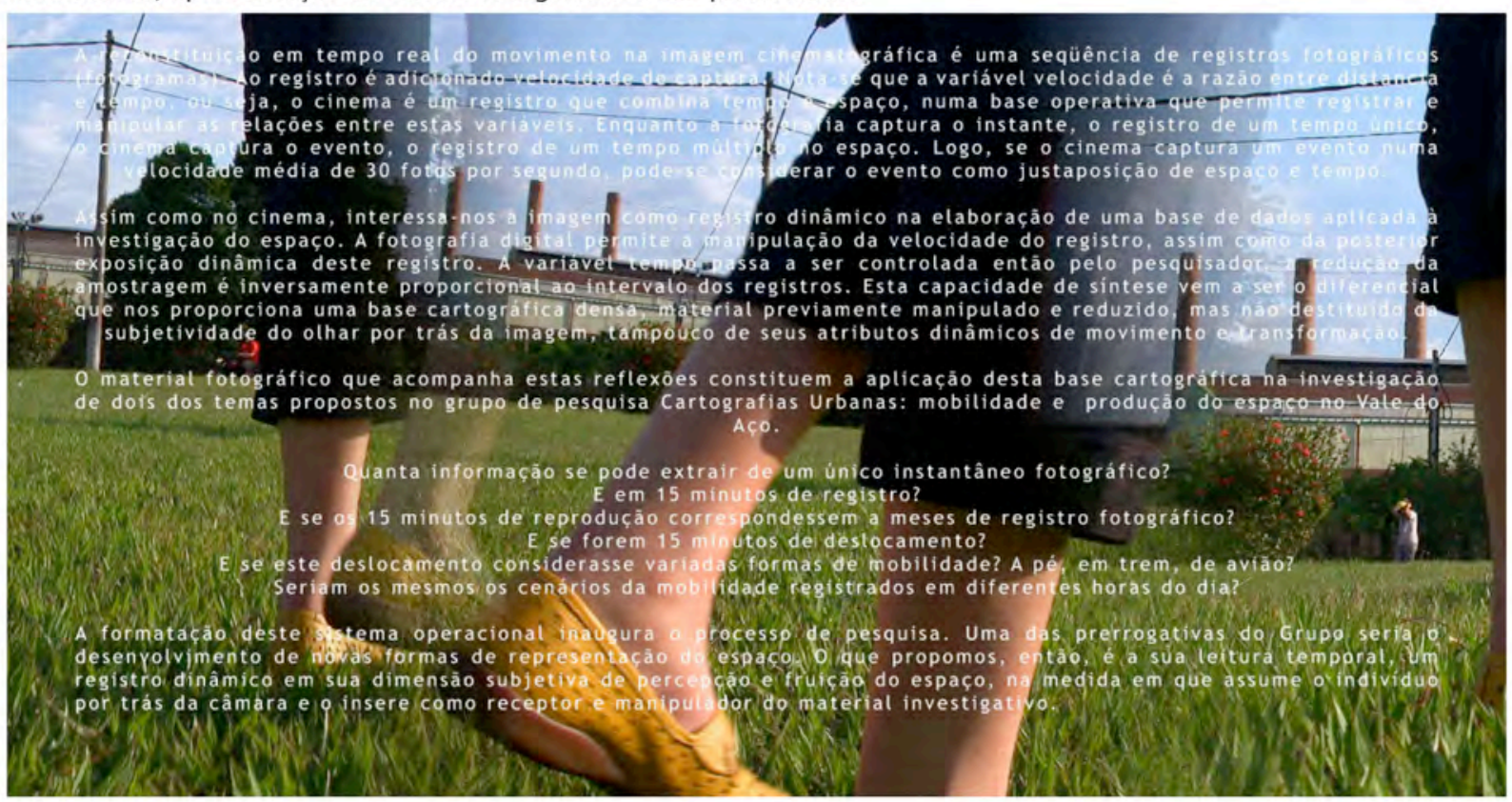




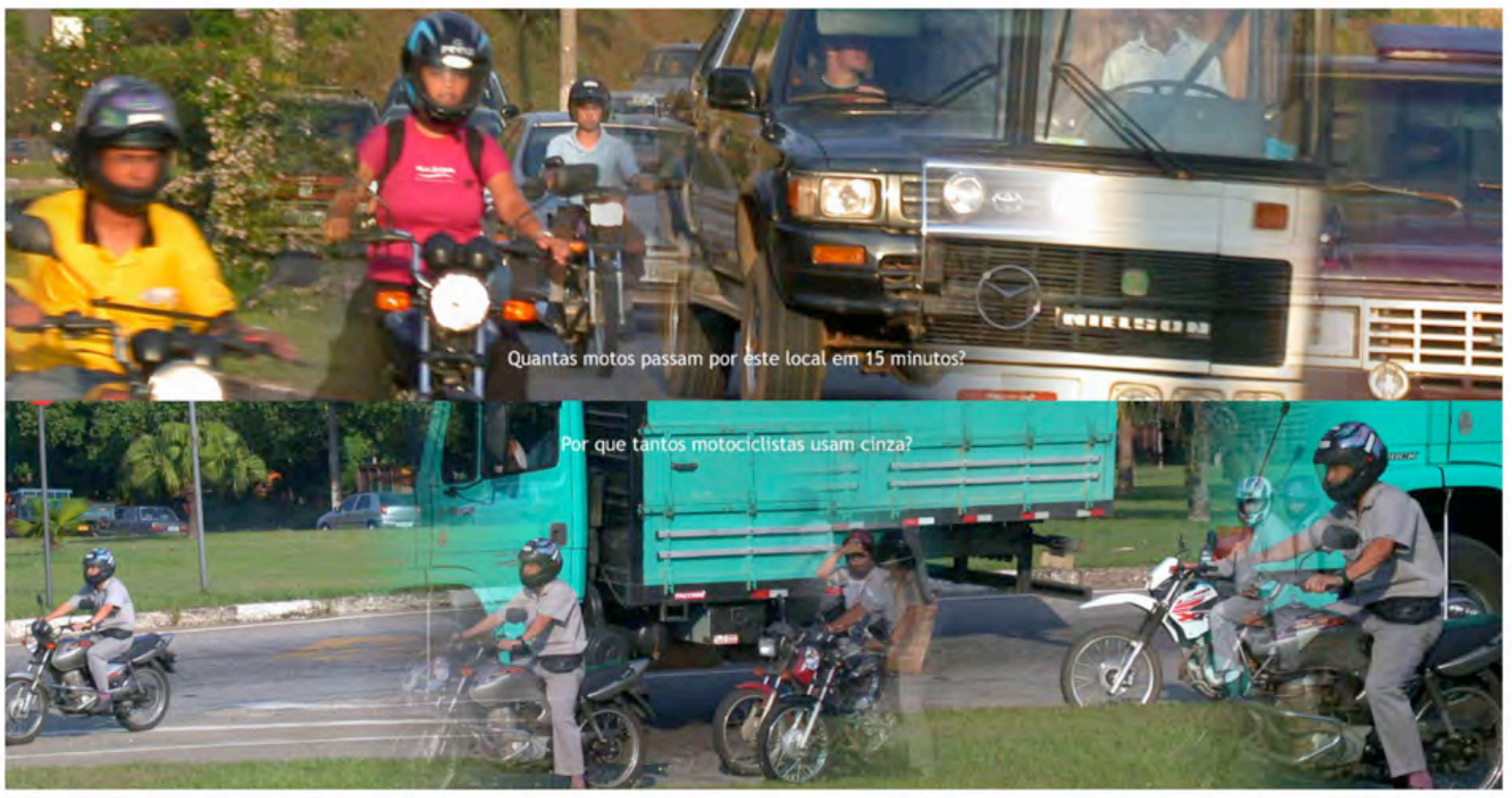

15 minutos, apresentação do ensaio fotográfico e dos panoramas.

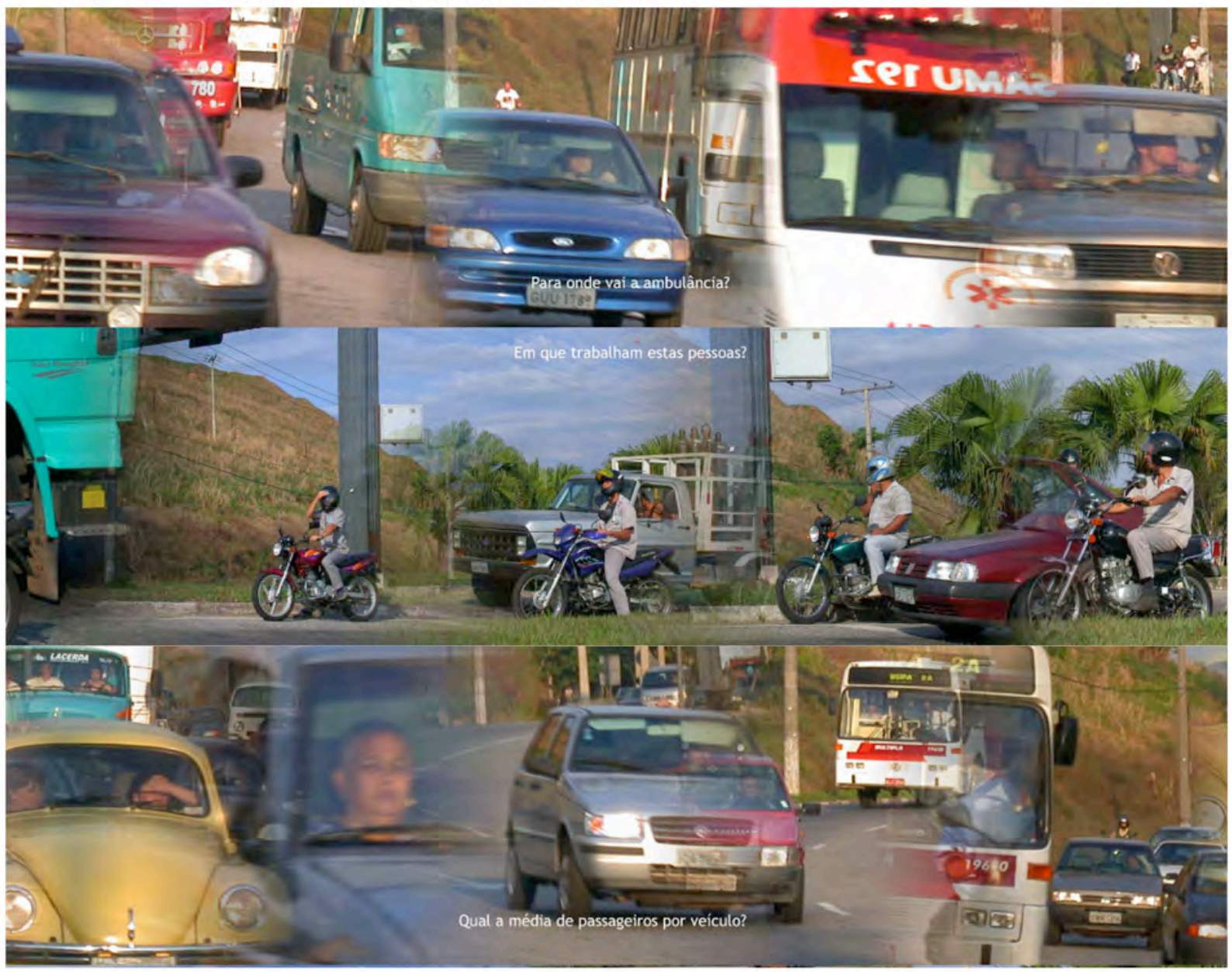




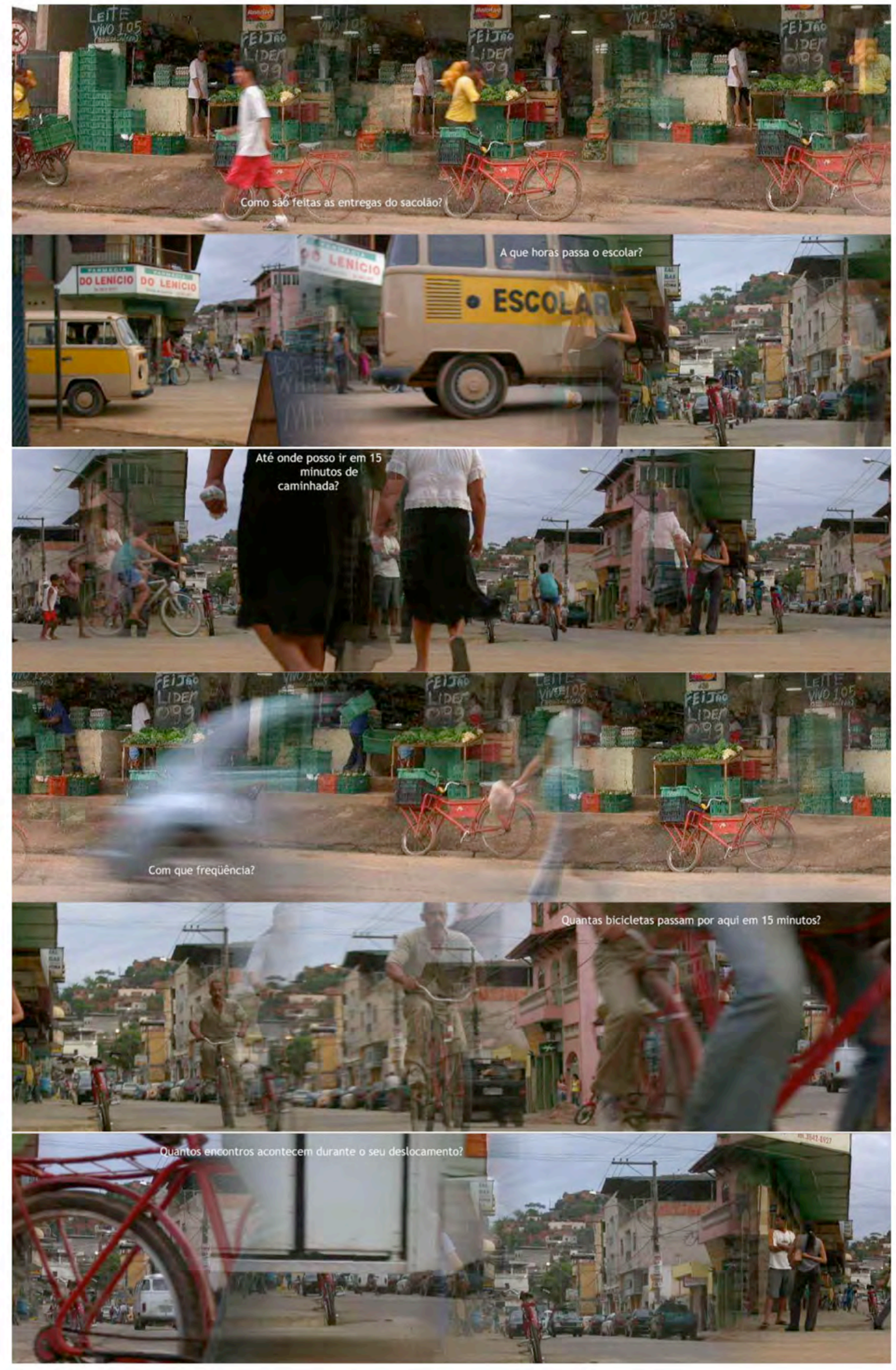




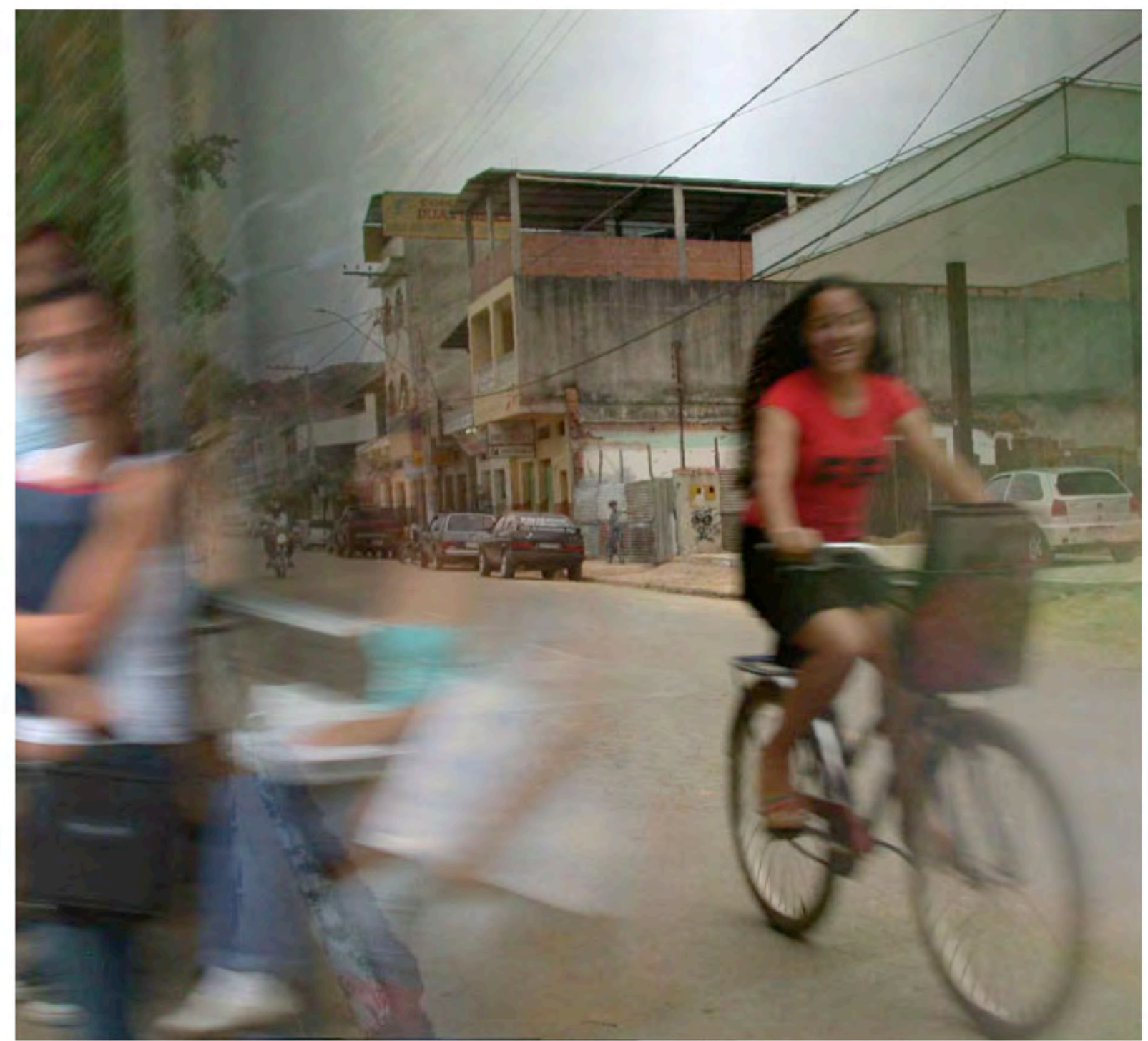

15 minutos, apresentação do ensaio fotográfico e dos panoramas.

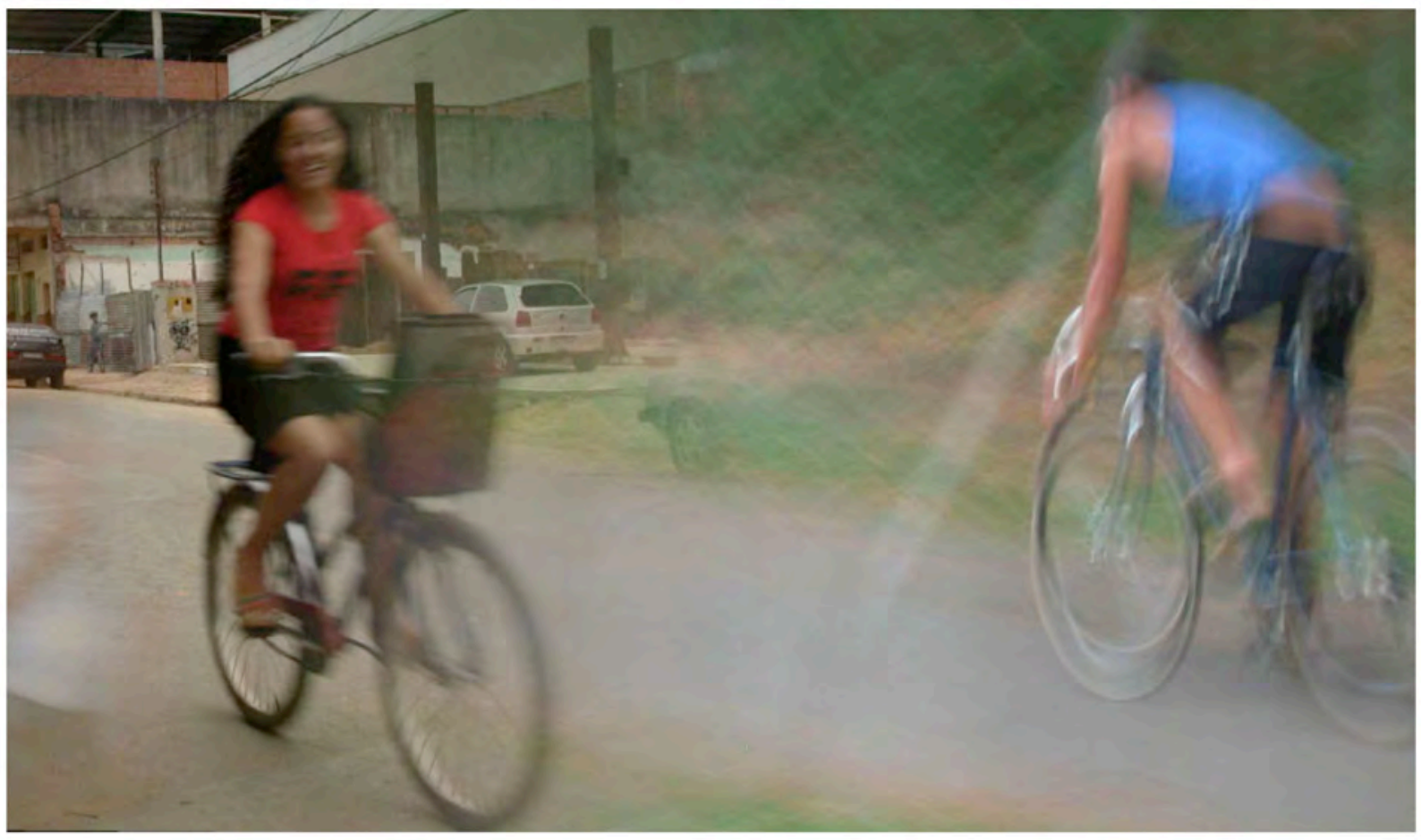

